\title{
WestVirginiaUniversity
}

THE RESEARCH REPOSITORY @ WVU

Graduate Theses, Dissertations, and Problem Reports

2003

\section{Characterization of wetland soils in the Beaver Creek watershed}

Kyle Michael Stephens

West Virginia University

Follow this and additional works at: https://researchrepository.wvu.edu/etd

\section{Recommended Citation}

Stephens, Kyle Michael, "Characterization of wetland soils in the Beaver Creek watershed" (2003).

Graduate Theses, Dissertations, and Problem Reports. 1728.

https://researchrepository.wvu.edu/etd/1728

This Thesis is protected by copyright and/or related rights. It has been brought to you by the The Research Repository @ WVU with permission from the rights-holder(s). You are free to use this Thesis in any way that is permitted by the copyright and related rights legislation that applies to your use. For other uses you must obtain permission from the rights-holder(s) directly, unless additional rights are indicated by a Creative Commons license in the record and/ or on the work itself. This Thesis has been accepted for inclusion in WVU Graduate Theses, Dissertations, and Problem Reports collection by an authorized administrator of The Research Repository @ WVU. For more information, please contact researchrepository@mail.wvu.edu. 
Characterization of Wetland Soils in the Beaver Creek Watershed

$$
\text { Kyle Stephens }
$$

Thesis submitted to

The Davis College of Agriculture, Forestry, and Consumer Sciences at West Virginia University

In partial fulfillment of the requirements for the degree of

\author{
Master of Science \\ In \\ Plant and Soil Sciences \\ John C. Sencindiver, Ph. D., Chair \\ Jeffrey Skousen, Ph. D \\ Ronald Fortney, Ph. D \\ Roger Viadero, Ph. D \\ Division of Plant and Soil Sciences \\ Morgantown, West Virginia \\ 2003
}




\section{Abstract \\ Characterization of Wetland Soils in the Beaver Creek Watershed \\ Kyle Stephens}

A proposed section of Appalachian Corridor $\mathrm{H}$ will pass through an area of the Beaver Creek watershed in Tucker County, West Virginia previously mined for the acidproducing Upper Freeport coal. Presently, partially-reclaimed spoils from past mining activities are generating acid mine drainage and releasing sediments into streams and other water bodies. Soils of acid mine drainage impacted wetlands and non-impacted wetlands were characterized to establish baseline soil status and to gain a better understanding of the chemical and physical processes occurring in these wetlands. The results of this study will be used to assist the West Virginia Division of Highways in constructing mitigation wetlands. Soils were described and sampled in the summer of 2001 in four wetlands. Soil samples were analyzed for particle size, $\mathrm{pH}$, exchangeable bases, extractable acidity, electrical conductivity, cation exchange capacity, sulfate, acid volatile sulfides, chromium reducible sulfides, total sulfur, total carbon, total nitrogen, and total iron. Platinum redox electrodes were placed in some wetlands to assess the near surface redox chemistry at 10 and $20 \mathrm{~cm}$. Wetlands receiving acid mine drainage generally contained higher levels of total sulfur, and the sulfur in these wetlands was more likely to be in the form of acid volatile sulfides, and/or chromium reducible sulfides. In general, in the non-impacted wetlands, over $90 \%$ of the sulfur was in the organic form. Total iron ranged from 3 to $385 u \mathrm{~mol} \mathrm{~g}^{-1}$ in non-impacted wetlands and 17 to $1356 u \mathrm{~mol} \mathrm{~g}^{-1}$ in acid mine drainage-impacted wetlands. Total nitrogen, cation exchange capacity, and total carbon in wetlands receiving acid mine drainage was generally lower than in the non-impacted wetlands. This was caused by an influx of sediments from mine spoils and decreased plant productivity. Electrical conductivity, particle size, extractable aluminum, $\mathrm{pH}$, and extractable bases were highly variable among acid mine drainage-impacted and non-impacted wetland soils. In wetlands receiving acid mine drainage, values for redox potential indicated conditions were present that would favor iron and sulfate reduction. The presence of acid volatile sulfide, coupled with high total sulfur and low sulfate indicated that in some acid mine drainageimpacted wetlands sulfur was being reduced and retained or never completely oxidized. 


\section{Acknowledgements}

First, I would like acknowledge my advisor Dr. John Sencindiver, without your patience and guidance none of this would have been possible. You were always willing to work with me in solving any problems encountered along the way. Your office was always open and your assistance was always available to me. For all your help, I thank you.

I would like to thank my committee members, Dr. Skousen, Dr. Fortney, and Dr. Viadero. Each one of you helped get this project started and assisted me in conducting my research along the way.

I would also like to say thanks to Dr. Bhumbla and Dr. McDonald for assisting me in my laboratory analyses and to the rest of the faculty and graduate students who were always supportive.

Lastly, I would like to say thank you to the West Virginia Division of Highways for providing the means to conduct this research. 


\section{Table of Contents}

$\begin{array}{lr}\text { Abstract } & \text { ii } \\ \text { Acknowledgements } & \text { iii } \\ \text { Introduction } & 1 \\ \text { Objectives } & 2\end{array}$

Literature Review 3

Hydric Soils $\quad 3$

Wetland Types $\quad 6$

Wetland Hydrology $\quad 7$

Biological and Chemical Properties of Wetlands 9

AMD Effects on Wetlands 11

$\begin{array}{ll}\text { Sulfur in Wetlands } & 15\end{array}$

$\begin{array}{lr}\text { Methods and Materials } & 18\end{array}$

$\begin{array}{lr}\text { Study Area } & 18\end{array}$

Soil Sampling $\quad 24$

Sample Preparation for Laboratory Analyses 26

Particle Size $\quad 26$

$\begin{array}{ll}\text { Chemical Analyses } & 27\end{array}$

$\begin{array}{ll}\text { Sulfur Fractionation Procedure } & 28\end{array}$

Field Analysis-Redox Potential 30

Results and Discussion $\quad 32$

Soil Morphology $\quad 32$

Particle Size Distribution $\quad 37$

Chemical Properties $\quad 40$

$\begin{array}{ll}\text { Summary and Conclusion } & 64\end{array}$

$\begin{array}{lr}\text { Literature Cited } & 69\end{array}$

$\begin{array}{ll}\text { Appendices } & \mathbf{7 5}\end{array}$

Soil Profile Descriptions $\quad 76$

$\begin{array}{ll}\text { Particle Size Distribution } & 108\end{array}$

Soil Chemical Properties 113

$\begin{array}{ll}\text { Vita } & 131\end{array}$ 


\section{List of Tables}

1. Average thickness of individual organic horizons (Oi, Oe, Oa), total thickness of the organic layer, and thickness of the solum for wetland soils in the Beaver Creek Watershed, WV.

2. Average particle size distribution and average textural classes for wetland soils in the Beaver Creek Watershed, WV.

3. Average $\mathrm{pH}$, electrical conductivity (Ec), extractable aluminum $(\mathrm{Al})$, and total iron $(\mathrm{Fe})$ for wetland soils in the Beaver Creek Watershed, WV.

4. Average total carbon and total nitrogen for the organic horizons in wetland soils of the Beaver Creek Watershed, WV.

5. Table 5. Average exchangeable calcium $(\mathrm{Ca})$, magnesium $(\mathrm{Mg})$, sodium $(\mathrm{Na})$, and potassium $(\mathrm{K})$ using the $\mathrm{pH} 7$ buffered ammonium acetate method for wetland soils in the Beaver Creek Watershed, WV.

6. Average total sulfur (S), sulfate $\left(\mathrm{SO}_{4}\right)$, acid volatile sulfur (AVS), chromium reducible sulfur (CRS), and organic sulfur for wetland soils of the Beaver Creek Watershed, WV.

7. Average percentage of total sulfur that each form of sulfur constitutes in wetland soils of the Beaver Creek Watershed, WV.

8. Particle size distribution and textural classes for soils in all wetlands.

9. Soil $\mathrm{pH}$, electrical conductivity $(\mathrm{Ec})$, total iron (Fe), extractable aluminum $(\mathrm{Al})$, total carbon $(\mathrm{C})$, and total nitrogen $(\mathrm{N})$ for all soils in all wetlands.

10. Cation exchange capacity (CEC); exchangeable calcium (Ca), magnesium $(\mathrm{Mg})$, sodium $(\mathrm{Na})$, and potassium $(\mathrm{K})$; and sum of all exchangeable bases for all wetland soils.

11. Redox potential(Eh) in $\mathrm{mV}$ and $\mathrm{pH}$ for one year at 10 and $20-\mathrm{cm}$ depths for wetland soils in Elder Swamp, Iron Pond and Railroad.

12. Total sulfur (S), sulfate sulfur $\left(\mathrm{SO}_{4}\right)$, acid volatile sulfides (AVS), chromium reducible sulfides (CRS), and organic sulfur (OS) for soils in all wetlands.

13. Percent of total sulfur that each sulfur fraction constitutes in all wetland soils. 


\section{List of Figures}

1. Aerial photograph of wetland sites in the Beaver Creek watershed, WV.

2. Map of Iron Pond Wetland in the Beaver Creek Watershed.

3. Aerial Photograph of Elder Swamp depicting wetland habitats and transect locations.

4. Average total carbon for all organic and mineral layers in wetlands of the Beaver Creek Watershed, WV.

5. Average cation exchange capacity (CEC) for all organic and mineral layers in wetlands of the Beaver Creek Watershed, WV.

6. Relationship between total carbon and cation exchange capacity (CEC) for all organic horizons and mineral layers in wetland soils in the Beaver Creek Watershed, WV.

7. Redox Potential (Eh) at $10 \mathrm{~cm}$ adjusted to represent $\mathrm{pH} 7 \mathrm{in}$ three sampling locations in Iron Pond wetland of the Beaver Creek Watershed, WV.

8. Redox Potential (Eh) at $20 \mathrm{~cm}$ adjusted to represent $\mathrm{pH} 7 \mathrm{in}$ three sampling locations in Iron Pond wetland of the Beaver Creek Watershed, WV.

9. Redox Potential (Eh) at $10 \mathrm{~cm}$ adjusted to represent $\mathrm{pH} 7 \mathrm{in}$ three sampling locations in Railroad Grade wetland of the Beaver Creek Watershed, WV.

10. Redox Potential (Eh) at $20 \mathrm{~cm}$ adjusted to represent $\mathrm{pH} 7 \mathrm{in}$ three sampling locations in Railroad Grade wetland of the Beaver Creek Watershed, WV.

11. Redox Potential (Eh) at $10 \mathrm{~cm}$ adjusted to represent $\mathrm{pH} 7 \mathrm{in}$ three sampling locations in Elder Swamp of the Beaver Creek Watershed, WV.

12. Redox Potential (Eh) at $20 \mathrm{~cm}$ adjusted to represent $\mathrm{pH} 7$ in three sampling locations in Elder Swamp of the Beaver Creek Watershed, WV. 


\section{INTRODUCTION}

Section 404 of the 1977 Clean Water Act defines jurisdictional wetlands as "those areas that are inundated or saturated by surface or ground water at a frequency and duration sufficient to support, and that under normal circumstances do support, a prevalence of vegetation typically adapted for life in saturated soil conditions". Wetlands generally include swamps, marshes, bogs, and similar areas. Wetlands provide unique functions, which make them invaluable to surrounding ecosystems. Wetlands filter water, recharge aquifers, help mitigate flood events, and may support rare and diverse wildlife populations (Mitsch and Gosselink, 2000).

In West Virginia, acid mine drainage (AMD) generated during and following mining of acid producing coal seams is a problem in many areas. Acid mine drainage is a sulfate and iron-rich, low $\mathrm{pH}$ drainage that can be detrimental to watersheds. Based upon observations that AMD passing through wetlands appears to lose iron and sulfate, and go up in $\mathrm{pH}$, many researchers have conducted studies on the ability of wetlands to treat AMD.

The Beaver Creek Watershed is an area that has been extensively mined for the acid producing Upper Freeport coal seam and as a result many partially reclaimed mine spoils are present in this watershed. Currently, some of these spoils are releasing AMD and sediments into adjacent wetlands, and these wetlands appear to be treating the drainage. The West Virginia Division of Highways (WVDOH) plans to construct a portion of Appalachian Corridor H in the Beaver Creek Watershed in Tucker County, WV. During road construction the WVDOH plans to minimize any potential impacts associated with the disturbance of existing wetland habitats and surrounding mine spoils. Furthermore, the WVDOH plans to use existing AMD-impacted wetlands as models for 
mitigation wetlands, which will be built following the construction of Corridor $\mathrm{H}$ in order to treat AMD collected from the disturbed spoils. This study will assist WVDOH in evaluating wetlands along the proposed route of Corridor $\mathrm{H}$.

\section{OBJECTIVES}

The objectives of this study were to:

1. Characterize soils in wetlands along the proposed route of Corridor H to establish wetland soil baseline status,

2. Compare chemical and physical properties of AMD-impacted wetland soils verses non-impacted wetlands soils, and

3. Make recommendations for construction of AMD treatment wetlands. 


\section{LITERATURE REVIEW}

\section{Hydric Soils}

Hydric soils form through unique pedogenic processes, which allow for the development of morphological features distinctly different from non-hydric soils. A hydric soil by definition is "a soil which is saturated, flooded, or ponded long enough during the growing season to develop anaerobic conditions in the upper part" (USDANatural Resources Conservation Service, 1995). Anaerobic conditions develop when water fills the soil pores, consequently decreasing the rate at which oxygen can diffuse through the soil (Mitsch and Gosselink, 2000). When a soil is submerged, the rate of oxygen diffusion through the water-filled pores is about one ten-thousandth of the rate of diffusion in a well-drained soil (Howeler and Bouldin, 1971). Under these conditions, the remaining dissolved oxygen $\left(\mathrm{O}_{2}\right)$ in the subsurface is rapidly consumed, and the redox potential (Eh) decreases as alternative electron acceptors, such as iron oxides, are used during anaerobic incubation (Ponnamperuma, 1972; Gambrell and Patrick, 1978; Faulkner and Patrick, 1992). Iron (Fe) oxides, manganese (Mn) and other elements may be reduced, allowing for the development of gray colors, or gleying, in the subsurface horizons (Environmental Laboratory, 1987). If the soil is not continually saturated for long periods, zones depleted of Fe and Mn and zones of Fe and Mn concentrations may develop. These features are indicators of alternating periods of oxidation and reduction (Faulkner and Patrick, 1992), during which Fe and Mn are mobilized by reduction and then immobilized in the form of oxides during the subsequent drying cycle (Pickering and Veneman, 1984).

In submerged hydric soils, decomposition rates will be drastically reduced compared to aerobic non-hydric soils, thus allowing for the accumulation of organic 
matter. McLatchey and Reddy (1998) reported that approximately three times more carbon is decomposed in aerobic soils compared to anaerobic soils. The reduced decomposition rates are a result of anaerobic respiration, which uses alternative electron acceptors such as nitrate $\left(\mathrm{NO}_{3}{ }^{-}\right)$, sulfate $\left(\mathrm{SO}_{4}{ }^{2-}\right)$, and carbon dioxide $\left(\mathrm{CO}_{2}\right)$, in place of $\mathrm{O}_{2}$ (Fuhrmann, 1998). Due to lower positive reduction potentials, all of these substances will accept electrons less readily then $\mathrm{O}_{2}$. In hydric soils that are not completely submerged, decomposition rates will still be reduced, but the rate will be a function of the hydrology.

The unique forms, functions, and properties of hydric soils has led to the formation of a hydric soils list by the Natural Resources Conservation Service (NRCS) (Soil Survey Division, 2000). For the development of a hydric soils list, a set of hydric soil criteria was established by the National Technical Committee for Hydric Soils (NTCHS). The following criteria reflect soils that are likely to meet the definition of a hydric soil. These criteria may only be applied to soils already classified by Soil Taxonomy (Soil Survey Staff, 1999). Wording of criteria 1 and 2 were changed in 2000 to meet recent changes in Soil Taxonomy (Soil Survey Division, 2000; Soil Survey Staff, 1999).

1. All Histels except Folistels and all Histosols except Folists, or

2. Soils in Aquic suborders, great groups, or subgroups, Albolls suborder, Historthels great group, Histoturbels great group, Pachic subgroups, or Cumulic subgroups that are:

a. Somewhat poorly drained with a water table equal to 0.0 foot $(\mathrm{ft})$ from the surface during the growing season, or

b. Poorly drained or very poorly drained and have either: 
(1) water table equal to $0.0 \mathrm{ft}$ during the growing season if textures are coarse sand, sand, or fine sand in all layers within 20 inches (in), or for other soils

(2) water table at less than or equal to $0.5 \mathrm{ft}$ from the surface during the growing season if permeability is equal to or greater then $6.0 \mathrm{in} /$ hour (h) in all layers within 20 in, or

(3) water table at less then or equal to $1.0 \mathrm{ft}$ from the surface during the growing season if permeability is less then $6.0 \mathrm{in} /$ hour (h) in any layer within 20 in, or

3. Soils are frequently ponded for long duration (7 days to a 1 month) or very long duration (greater than 1 month) during the growing season, or

4. Soils that are frequently flooded for long duration or very long duration during the growing season.

When delineating a potential wetland area, it is necessary to know the extent of hydric soils. Whether or not the classified soil of an area meets the hydric soil criteria will not be enough information to discern the exact extent of a hydric soil. The criteria are only applied to the classified soils, and mapping units of these soils are not homogenous. Mapping units may encompass inclusions of hydric and or non-hydric soils. Therefore, the NRCS has established a set of field indicators, which can be used to determine whether or not a specific site contains a hydric soil. Field indicators have some variation based upon differences in soil texture, but these variations are slight and in general the following list presented in the Corps of Engineers Wetland Delineation Manual (Environmental Laboratory, 1987) may be used to determine the presence or absence of hydric soils. A more detailed list of hydric soil field indicators can be found 
in Field Indicators of Hydric Soils in the United States (United States Department of Agriculture-Natural Resources Conservation Service, 1998). The following outline summarizes these indicators.

1. Organic soils (Histosols)

2. Histic epipedons

3. Sulfidic materials

4. Aquic or peraquic moisture regime

5. Reducing Conditions

6. Soil Colors

(a) Gleyed soils

(b) Mottled soils

- Matrix chroma 2 or less if the soil is mottled

- Matrix color of 1 or less if the soil unmottled

7. Iron and manganese concretions

\section{Wetland Types}

Typical names for wetlands are bogs, bottomlands, fens, marshes, swamps, wet meadows, and wet prairies. Each of these are common names for a wetland, but each have different meanings. Mitsch and Gosselink (2000) defined these types of wetlands as follows:

Bog. A peat-accumulating wetland that has no significant inflows or outflows and supports acidophillic mosses, particularly sphagnum.

Bottomland. Lowlands along streams and rivers, usually on alluvial floodplains that are 
periodically flooded. When forested, it is called a bottomland hardwood forest in the southeastern and eastern United States.

Fen. Peat-accumulating wetland that receives some drainage from surrounding mineral soils and usually supports marshlike vegetation.

Marsh. A frequently or continually inundated wetland characterized by emergent herbaceous vegetation adapted to saturated soil conditions.

Swamp. Wetland dominated by trees and shrubs (U.S. definition).

Wet Meadow. Grassland with waterlogged soil near the surface but without standing water for most of the year.

Wet Prairie. Similar to a marsh, but with water levels usually intermediate between a marsh and a wet meadow.

\section{Wetland Hydrology}

The Corps Of Engineers (COE) Wetlands Delineation Manual (Environmental Laboratory, 1987) states that "wetland hydrology encompasses all hydrological characteristics of areas that are periodically inundated or have soils saturated to the surface at some time during the growing season". The hydrology of wetlands is often variable throughout the year, as they are subjected to rapid changes of the inflows and outflows. Pickering and Veneman (1984) researched changes in a hydric soil over a twoyear period. They found water table fluctuations of as much as $45 \mathrm{~cm}$ throughout the year, but from year to year the hydroperiods remained similar.

Observations about water table fluctuations can be used to determine a wetland hydroperiod, or the seasonal pattern of the water level in a wetland (Mitsch and Gosselink, 2000). The hydroperiod (represented in the following equation) is the sum of 
all inflows and outflows, which are influenced by terrain, proximity to water, climate, and antecedent moisture content (Mitsch and Gosselink, 2000).

$$
\Delta V=P_{n}+S_{i}+G_{i}-E_{t}-S_{o}-G_{o} \pm T
$$

where:

$\Delta \mathrm{V}=$ Change in the volume of water stored

$\mathrm{P}_{\mathrm{n}}=$ Net precipitation

$\mathrm{S}_{\mathrm{i}}=$ Surface inflow

$\mathrm{G}_{\mathrm{i}}=$ Groundwater inflow

$\mathrm{E}_{\mathrm{t}}=$ Evapotranspiration

$\mathrm{S}_{\mathrm{o}}=$ Surface outflow

$\mathrm{G}_{\mathrm{o}}=$ Groundwater outflow

$\mathrm{T}=$ Tidal inflow $(+)$ or outflow $(-)$

Chemical, physical, and biological features of wetlands are all a function of the wetland hydrology. Mitsch and Gosselink (2000) state that wetland hydrology affects species development, primary productivity, organic matter accumulation, and nutrient cycling through changes in the hydroperiod. Areas that are flooded for a long duration, may develop water tolerant vegetation, develop anoxic conditions, accumulate organic matter and decrease in productivity. Wetlands flooded often, but only for short durations, may be more productive as organic matter is decomposed at a faster rate, nutrients are consistently cycled, and $\mathrm{O}_{2}$ is not depleted from the soil (Mitsch and Gosselink, 2000).

Research shows that the wetland water table will fluctuate with changes in the season. Pickering and Veneman (1984) observed that the highest water table for a hydric soil in Massachusetts occurred from January to March, and lowest water table occurred in 
the late summer and early fall months. Vepraskas and Wilding (1983) reported finding a similar hydroperiod for two hydric soils in Texas.

\section{Biological and Chemical Properties of Wetlands}

Wetlands are characterized by reduced soil conditions caused by saturation of soil pores with water. The rate of diffusion of $\mathrm{O}_{2}$ through saturated pores is onetenthousandth the rate of diffusion through non-submerged soil (Howeler and Bouldin, 1971). As a result the wetland soils can quickly become depleted of dissolved $\mathrm{O}_{2}$ as microorganisms use $\mathrm{O}_{2}$ for decomposition. As the water table rises, the $\mathrm{O}_{2}$ diffusion rates and $\mathrm{O}_{2}$ concentrations decrease (Callebaut et al., 1982). Under these conditions, decomposition of organic matter is slowed (Reddy and Patrick, 1975; McLatchey and Reddy, 1998) as microorganisms decompose organic matter via anaerobic pathways using terminal electron acceptors other then $\mathrm{O}_{2}$ (Vepraskas and Faulkner, 2001). In turn, facultative obligate anaerobes will sequentially reduce the following compounds in place of $\mathrm{O}_{2}: \mathrm{NO}_{3}{ }^{-}$, manganese oxide $\left[\mathrm{MnO}_{2}\right]$, ferric hydroxide $\left[\mathrm{Fe}(\mathrm{OH})_{3}\right], \mathrm{SO}_{4}{ }^{2-}$, and $\mathrm{CO}_{2}$ (Ponnamperuma , 1972: Patrick and Jugsujinda, 1992).

For a soil to be reduced it must be saturated, contain readily decomposable organic tissues, contain a microbial population that decomposes the tissue, and water should be stagnate or moving slowly (Meek et al., 1968). The reduced soil state will be a result of the lowering of the redox potential below $200 \mathrm{mV}$ (Ponnamperuma, 1972).

Research shows that redox potential will decrease as a soil becomes submerged and $\mathrm{O}_{2}$ is depleted (Vepraskas and Wilding, 1983; Faulkner and Patrick, 1992: Megonigal et al., 1993). Under low redox potentials, microbial biomass carbon (C) and nitrogen (N) will decrease, which will lead to lower mineralization rates (McLatchey and Reddy, 1998). 
In the aerobic soil zone, nitrogen can undergo nitrification, ammonification, and denitrification, and it can be fixed from the atmosphere (Mitsch and Gosselink, 2000). In the anaerobic zone, nitrogen is only subjected to denitrification or ammonification (Ponnamperuma, 1972). Yet, ammonification is the dominant process in submerged wetland soils, since the redox potential is often not high enough to support denitrification (Hou et al., 2000). Major nitrogen sources for wetlands are atmospheric deposition, $\left(\mathrm{NO}_{3}{ }^{-}\right.$, and $\left.\mathrm{NH}_{4}{ }^{+}\right), \mathrm{N}_{2}$ fixation, and groundwater additions of $\mathrm{NO}_{3}$ (Vepraskas and Faulkner, 2001).

Bacteria reduce manganese only when $\mathrm{NO}_{3}{ }^{-}$is depleted from the soil. This occurs at a critical redox potential of $200-250 \mathrm{mV}$ (Patrick and Jugsujinda, 1992). Manganese is reduced from the form of $\mathrm{Mn}^{4+}$ oxides to $\mathrm{Mn}^{2+}$ in the anoxic zone. Once this occurs $\mathrm{Mn}$ is soluble and it can diffuse or move by mass flow into the wetland surface vegetation where it may reoxidize (Ponnamperuma, 1972).

Iron reduction is the reaction that affects color of wetland soils. When $\mathrm{Fe}$ is oxidized it exists in the ferric $\left(\mathrm{Fe}^{3+}\right)$ form as an oxide or hydroxide. This in turn imparts red, brown, or yellow colors on the soil, which are indicators of the aerobic zone (Vepraskas and Faulkner, 2001). The anaerobic zone favors reduction of iron, which is indicated by gray colors and reduced chromas (Vepraskas and Wilding, 1983). Ferrous iron $\left(\mathrm{Fe}^{2+}\right)$ first appears in solution when all $\mathrm{NO}_{3}$ has been removed from the soil and the redox potential is below $100 \mathrm{mV}$ (Patrick and Jugsujinda, 1992). The soluble $\mathrm{Fe}^{2+}$ then can move by mass flow or diffusion to the surface of the wetland (Ponnamperuma, 1972), or out of the wetland if the water table is lowered. Here it can cover root surfaces in the $\mathrm{Fe}^{3+}$ and $\mathrm{Fe}^{2+}$ forms (Wang and Peverly, 1999). These coatings can form a barrier around roots, which inhibits nutrient uptake by plants (Gambrell and Patrick, 1978). 
Sulfur (S) reduction is an active process in wetlands as shown by accumulation of inorganic or reduced S under anaerobic conditions (Feng and Hsieh, 1998). Sulfate reduction has been reported to occur at a redox potential of less then $-100 \mathrm{mV}$ (Patrick and Jugsujinda, 1992). Wieder et al. (1987) observed that organic S constituted 83-85\% of the total S in a freshwater West Virginia wetland, with $72-89 \%$ of the organic S in the carbon-bonded form. Pyrite $\left(\mathrm{FeS}_{2}\right)$ is the main end product of anaerobic $\mathrm{SO}_{4}$ reduction (Ponnamperuma, 1972).

Under anaerobic conditions organic matter decomposition rates are slowed and less $\mathrm{CO}_{2}$ is produced (Ponnamperuma, 1972). Methane $\left(\mathrm{CH}_{4}\right)$, a typical end product of anaerobic decomposition, is a gas that is produced as bacteria (methanogens) use $\mathrm{CO}_{2}$ as an electron acceptor (Mitsch and Gosselink, 2000). Methane may escape to the atmosphere, yet concentrations of $\mathrm{CH}_{4}$ are found to increase with soil depth (Yavitt et al., 1990). The potential for $\mathrm{CH}_{4}$ production is greatest at the surface where the concentrations remain the lowest (Yavitt et al., 1990). Methane production is greater in freshwater wetlands rather then salt water wetlands, which is most likely due to the higher S concentrations in the latter (Mitsch and Gosselink, 2000).

\section{AMD Effects on Wetlands}

Acid mine drainage is an acidic, sulfate-rich runoff that forms upon exposure of $\mathrm{FeS}_{2}$ or other sulfidic materials to $\mathrm{O}_{2}$ and $\mathrm{H}_{2} \mathrm{O}$. Though the chemistry is variable, AMD typically has high metal concentrations, with Fe and $\mathrm{Mn}$ in the range of 39 to 7300 and 4 to $126 \mathrm{mg} \mathrm{L}$, and $\mathrm{pH}$ range of 2 to 4.5 (Appalachian Regional Commission, 1969).

Furthermore, elevated aluminum $(\mathrm{Al})$ and $\mathrm{SO}_{4}{ }^{2-}$ concentrations are often associated with AMD (Skousen et al., 2000). In the Appalachian Coal Mining Region, $\mathrm{FeS}_{2}$ (commonly 
found in coal seams or their contiguous strata) is the primary mineral that forms AMD. When exposed to $\mathrm{O}_{2}$ and $\mathrm{H}_{2} \mathrm{O}, \mathrm{FeS}_{2}$ is oxidized, and $\mathrm{Fe}^{+2}$, acidity $\left(\mathrm{H}^{+}\right)$, and $\mathrm{SO}_{4}{ }^{2-}$ are generated (Geidel and Caruccio, 2000). This process occurs through the following series of chemical reactions presented by Stumm and Morgan (1981).

$$
\begin{gathered}
\mathrm{FeS}_{2}+7 / 2 \mathrm{O}_{2}+\mathrm{H}_{2} \mathrm{O}=\mathrm{Fe}^{2+}+2 \mathrm{SO}_{4}{ }^{2-}+2 \mathrm{H}^{+} \\
\mathrm{Fe}^{2+}+1 / 4 \mathrm{O}_{2}+\mathrm{H}^{+}=\mathrm{Fe}^{+3}+1 / 2 \mathrm{H}_{2} \mathrm{O} \\
\mathrm{Fe}^{3+}+3 \mathrm{H}_{2} \mathrm{O}=\mathrm{Fe}(\mathrm{OH})_{3(\mathrm{~S})}+3 \mathrm{H}^{+} \\
\mathrm{FeS}_{2}+14 \mathrm{Fe}^{3+}+8 \mathrm{H}_{2} \mathrm{O}=15 \mathrm{Fe}^{2+}+2 \mathrm{SO}_{4}{ }^{2-}+16 \mathrm{H}^{+}
\end{gathered}
$$

In Eq. [2], acidity $\left(\mathrm{H}^{+}\right), \mathrm{Fe}^{+2}$, and $\mathrm{SO}_{4}{ }^{2-}$ are produced when $\mathrm{FeS}_{2}$ is initially oxidized. According to $\mathrm{Eq}$ [3], $\mathrm{Fe}^{+2}$ is then oxidized by $\mathrm{O}_{2}$ to the $\mathrm{Fe}^{3+}$ form. The $\mathrm{Fe}^{3+}$ is then either removed from solution in the form of $\mathrm{Fe}(\mathrm{OH})_{3(\mathrm{~S})}$ as shown in Eq. [4], or it oxidizes $\mathrm{FeS}_{2}$ thereby initiating a propagation cycle in which additional $\mathrm{Fe}^{+2}$ and acidity are produced (Singer and Stumm, 1970).

Singer and Stumm (1970) observed that no oxidation of pyrite occurred for a week in the absence of $\mathrm{Fe}^{3+}$, whereas in the presence of $\mathrm{Fe}^{3+}, \mathrm{FeS}_{2}$ was rapidly oxidized. From this they concluded that Eq. [3] is the rate limiting step in the oxidation of pyrite. This step is catalyzed by the presence of the $\mathrm{Fe}^{+2}$ oxidizing bacteria, Thiobacillus ferooxidans (Silverman, 1967). Singer and Stumm (1970) measured $\mathrm{Fe}^{+2}$ oxidation rates under sterile and normal conditions. From this they estimated that the presence of oxidizing bacteria increased the oxidation of $\mathrm{Fe}^{+2}$ by a factor of $10^{6}$.

Coal mine operators must comply with the National Pollution Discharge Elimination System (NPDES) issued under the Clean Water Act of 1972 (Skousen et al., 2000). When AMD is present, additional treatment steps may have to be instituted so 
discharge standards can be achieved. Chemicals are often used, but costs of continuous active treatment systems are expensive (Skousen et al., 2000). In order to keep costs low and comply with federal standards, coal mining operators often install low maintenance, passive wetland treatment systems.

Scientists have observed that natural wetlands receiving AMD have the potential to decrease acidity, and retain metals (Wieder and Lang, 1984; 1986; Tarutis and Unz, 1992). These observations prompted studies that examined the treatment of AMD with constructed wetlands (Wieder, 1993; Stark et al., 1996; Tarutis and Unz, 1996). In each study wetlands were shown to reduce concentrations of soluble Fe, and reduce acidity in the AMD. Furthermore, some studies have shown that wetlands have the ability to remove soluble Al and Mn from AMD (Wieder, 1993; Wieder et al., 1988), while this phenomenon was not observed in other studies (Wieder et al., 1990; Stark et al., 1996). Wieder (1993) found the retention of soluble Fe in constructed wetlands to be finite, as outlet Fe concentrations eventually equaled those of the inlet AMD. Yet, the wetlands still initially decrease Fe concentrations in the AMD as Fe oxides precipitate and $\mathrm{Fe}$ is organically bound (Henrot and Wieder, 1990). The Fe retained in aerobic wetlands is primarily in the Fe oxide form followed by the organically bound fraction, residual Fe and exchangeable Fe (Wieder, 1990; Henrot and Wieder, 1990). Anaerobic wetlands retain $\mathrm{Fe}$ in the oxidized form primarily in the surface layer, but the subsurface retains Fe in the chemically and microbiologically reduced forms (Stark et al., 1995).

Vegetation type does not influence Fe retention in wetlands (Wieder, 1990; Stark et al., 1995), but $\mathrm{Al}$ and $\mathrm{Mn}$ retention is slightly increased in wetlands planted with cattails (Typhia latifolia) (Wieder et al., 1990). Aluminum and Mn are primarily retained in both the organically bound fraction and in the exchangeable fraction (Wieder et al., 
$1988 ; 1990)$, with cattails promoting some oxidation of these metals at the root surface (Wieder, 1990). Vegetation may aid in the treatment of AMD by adding organic matter, creating sheet flow rather than channelization, diffusing the water flow (Stark et al., 1994), and stimulating microbial activity around the root surfaces (Wieder, 1993).

The ability of the wetland to treat AMD will depend on the type of wetland constructed. Wieder (1993) worked with shallow $(\leq 30 \mathrm{~cm})$ aerobic wetlands that became inefficient retaining $\mathrm{Fe}$ and $\mathrm{H}^{+}$, whereas Stark et al. (1995) constructed deeper $(>30 \mathrm{~cm})$ anaerobic wetlands, which retained more iron and maintained a decreased $\mathrm{pH}$ through the entire study period. Aerobic wetlands stimulate metal oxidation and hydrolysis, which causes precipitation of metals, whereas anaerobic wetlands perform these functions in the surface layers, but primarily rely on chemical and microbial reactions that precipitate metals and generate alkalinity (Skousen et al., 2000).

Tarutis and Unz (1992) noted that natural wetlands receiving AMD display decreasing metal concentrations with depth. This is explained by the oxidation of metals (particularly Fe) at the surface of the wetland (Tarutis and Unz, 1992). Wieder and Lang (1986) compared a wetland receiving AMD verses several natural unimpacted wetlands. They concluded that overall concentrations of $\mathrm{Fe}, \mathrm{Mn}, \mathrm{Al}$, and $\mathrm{SO}_{4}{ }^{2-}$ in the AMDimpacted wetland soils will increase, and OM accumulation will decrease, with the latter caused by accelerated decomposition rates and increased sediment load. The presence of Fe oxides, Mn oxides, and organic matter in the anoxic zone is the cause of accelerated decomposition rates as bacteria use the oxides as terminal electron acceptors in place of $\mathrm{O}_{2}$ (Tarutis and Unz, 1992). As Mn and Fe are reduced, concentrations of these metals in interstitial waters will increase (Tarutis and Unz, 1992). Furthermore, $\mathrm{SO}_{4}{ }^{2-}$ becomes the terminal electron acceptor if $\mathrm{Fe}$ and $\mathrm{Mn}$ oxide concentrations continually decline (Tarutis 
and Unz, 1992). The $\mathrm{SO}_{4}{ }^{2-}$ is reduced to a carbon-bound form or to an iron sulfide form (Wieder and Lang, 1986).

Wieder and Lang (1986) and Tarutis and Unz (1992) found that there is a lower Fe adsorption potential in wetlands receiving AMD than wetlands not receiving AMD, which indicated that exchange sites were becoming saturated with Fe. This will generate additional acidity as the $\mathrm{H}+$ is displaced into solution from the exchange sites (Tarutis and Unz, 1992).

\section{Sulfur in Wetlands}

In wetland soils, sulfur can exist either in the organic or the inorganic form. Studies have shown that 76 to $98 \%$ of sulfur in freshwater wetland soils exists in the organic form (Wieder et al., 1987; Wieder and Lang 1986; Spratt et al., 1987; Novak and Wieder, 1992; Chapman, 2001). This is in sharp contrast to wetlands receiving saltwater where $84-97 \%$ of the S may be in the inorganic pyrite form (Kaplan et al., 1973). Most of the organic sulfur in freshwater wetlands is in the C-bonded form (71 to $94 \%$ ), and the remaining organic $\mathrm{S}$ is in the ester sulfate form (Wieder et al., 1987; Spratt et al., 1987). Inorganic $\mathrm{S}$ occurs in many different forms that have varying oxidation states. Sulfur can exist in the following forms: $\mathrm{SO}_{4}{ }^{2-}$, elemental $\left(\mathrm{S}^{\circ}\right)$, monosulfides particularly iron monosulfides (FeS), disulfides such as $\mathrm{FeS}_{2}$, and as $\mathrm{H}_{2} \mathrm{~S}$ gas (Wieder and Lang, 1986). Sulfur in the $\mathrm{SO}_{4}{ }^{2-}$ form is in the +6 valence state and this is the most oxidized form of sulfur in wetland soils. Sulfate tends to be in higher concentrations at the surface of wetland soils (Novak and Wieder, 1992), where oxygen still makes it way into the soil. Wieder et al. (1987) reported that $\mathrm{SO}_{4}{ }^{2-}$ in a West Virginia bog accounted for only $4.1 \%$ of the inorganic sulfur at an $8-\mathrm{cm}$ depth, and $3.2 \%$ at a depth of $30 \mathrm{~cm}$. 
Sulfur in the elemental form is in the zero charged valence state, and this form of sulfur makes up only a small portion of the inorganic sulfur pool. Wieder et al. (1987) reported that $\mathrm{S}^{\circ}$ accounted for 5.2 to $13.5 \%$ of the inorganic sulfur with more $\mathrm{S}^{\circ}$ observed at the lower depths in the soil profile. Spratt et al. (1987) reported that $\mathrm{S}^{\circ}$ constituted only $6.4 \%$ of the inorganic sulfur at a depth of 7.5 to $10 \mathrm{~cm}$. Elemental sulfur is more oxidized than $\mathrm{FeS}$ and $\mathrm{FeS}_{2}$, therefore under strong reducing conditions $\mathrm{S}^{\circ}$ can be further reduced to the iron sulfide form.

Sulfur in FeS is in the -2 valence state, which is the most reduced form of sulfur. Iron monosulfides generally make up a larger portion of the inorganic sulfur than $\mathrm{S}^{\circ}$ and $\mathrm{SO}_{4}{ }^{2-}$. Studies have shown that anywhere from 3.0 to $16.7 \%$ of the inorganic sulfur is in this form (Wieder and Lang 1986; Spratt et al. 1987; Wieder et al. 1987). Monosulfides are the least stable form of sulfide and they are easily oxidized when exposed to atmospheric conditions.

The reaming inorganic sulfur is in the thermodynamically stable $\mathrm{FeS}_{2}$ phase. In three separate studies involving five different peat bogs, $\mathrm{FeS}_{2}$ always constituted at least $43 \%$ of the inorganic pool and in two wetlands it was reported to account for more than $74 \%$ of the inorganic sulfur (Wieder and Lang 1986; Spratt et al. 1987; Wieder et al. 1987). Pyrite is the stable end product of sulfur reduction, and it forms either through direct precipitation of ions in solution as:

$$
\mathrm{Fe}^{2+}+\mathrm{S}^{\circ}+\mathrm{H}_{2} \mathrm{~S} \rightarrow \mathrm{FeS}_{2}+2 \mathrm{H}^{+}
$$

or indirectly through an intermediate FeS form which subsequently reacts with the more oxidized S (Laudon, 1989):

$$
\begin{gathered}
\mathrm{Fe}^{2+}+\mathrm{H}_{2} \mathrm{~S} \rightarrow \mathrm{FeS}+2 \mathrm{H}^{+} \\
\mathrm{FeS}+\mathrm{S}^{\circ} \rightarrow \mathrm{FeS}_{2}
\end{gathered}
$$


The form of sulfur in wetland soils depends on the soil conditions. For iron sulfides to form, $\mathrm{SO}_{4}{ }^{2-}$ must be readily available, $\mathrm{Fe}$ must be present, organic materials must be available as an energy source to sulfate-reducing bacteria (Griffin and Ranbenhorst, 1989), and the redox potential must be low enough for sulfur to be reduced. If all of these conditions are not present, then sulfur will not be reduced. 


\section{MATERIALS AND METHODS}

\section{Study Area}

All wetland sites were located in Tucker County, WV, along a 19-km (12 mile) section of Rt. 93 (Figure 1). This area of Tucker County has been mined extensively for Bakerstown coal and acid producing Upper Freeport coal. Several partially reclaimed surface mines lined the southeastern side of Rt. 93, and active and reclaimed mines were situated along the northwestern side. The minesoils along the southeast of Rt. 93 supported planted red pine (Pinus resinosa), black alder (Alnus glutinosa), and autumn olive (Elaeagnus umbellata).

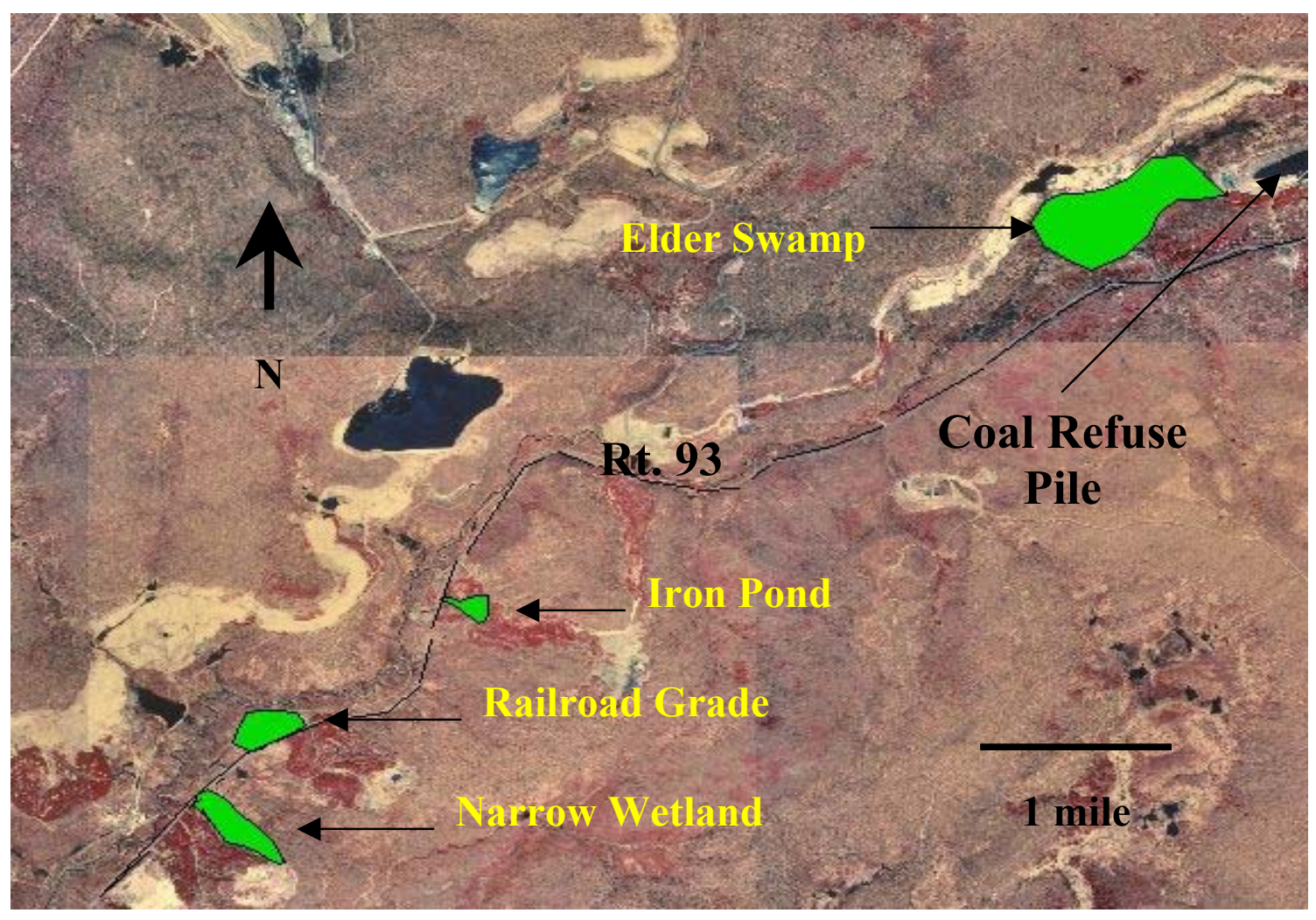

Figure 1. Aerial photograph of wetland sites in the Beaver Creek watershed, WV. Wetlands are green areas, mine spoils are dark red areas. 
Tucker County has an average yearly temperature of $8^{\circ} \mathrm{C}$ and an average yearly precipitation of $136 \mathrm{~cm}$ (Losche and Beverage, 1967). Winters tend to be long in the study area, and the growing season is short (Losche and Beverage, 1967).

Both the Pennsylvanian and Mississippian Systems dominate the geology of the study area. There are no Mississippian coal or limestone beds in this part of Tucker County, only green and red shales mixed with sandstone (West Virginia University, 1995). The Pennsylvanian System sits above the Mississippian System and contains the Pottsville, Allegheny, and Conemaugh Groups. The Pottsville Group lies underneath the Allegheny Group, which contains the Upper Freeport coal. Above this group, lies the Conemaugh Group, which contains the Bakerstown coal bed. Both the Pottsville and Conemaugh Groups have sandstones and shales surrounding the coal beds.

The major soil series in this area of Tucker County are the Brinkerton and Lickdale (Losche and Beverage, 1967). The Brinkerton Series (fine-silty, mixed, superactive, mesic Typic Fragiaqualfs) (Soil Survey Division, 2003) was mapped near each wetland. The Lickdale Series (fine-loamy, mixed, acid, mesic Humic Endoaquepts) (Soil Survey Division, 2003) was mapped near Narrow Wetland, Railroad Grade, and Fen-Marsh (Losche and Beverage, 1967).

Vegetation of this area was variable due to the presence of hydric and non-hydric soils. In the soils that surround the wetlands, a mix of pines (Pinus spp.), spruce (Picea spp.) and poplar (Populus spp.) were the dominant tree species, and the understory consisted of rhododendron (Rhododendron spp.), and blueberry (Vaccinium spp.) (Losche and Beverage, 1967). In the wetlands, sphagnum moss (Sphagnum spp.), hair-cap moss (Polytrichum spp.), cattail (Tyhia latifolia), St Johns wort (Hypericum spp.), alder (Alnus rugosa), sedges (Carex spp.), and other wetland species were the dominant vegetation. 
The Bakerstown coal bed is situated along the northwestern side of Rt. 93. It is not considered to be acid producing and it may even generate some alkalinity (West Virginia University, 1995), but it does not impact wetlands in this study. The areas along the southeastern side of Rt. 93 were mined for the acid producing Upper Freeport coal, and runoff from the spoils has caused the current sedimentation and AMD problems in Beaver Creek and the surrounding wetlands.

The four wetlands sampled in this study are identified as the following: Narrow Wetland, Iron Pond, Railroad Grade, and Elder Swamp (Figure 1). Narrow Wetland is a relatively flat wetland located adjacent to Rt. 93 on the southeastern side. Soils were described at six sampling locations in this wetland, and samples were taken at three locations. The water table in this wetland is at or near the surface through much of the year. Drainage appears to be impeded by the presence of Rt. 93, which crosses at the wetland terminus. The soils appear to be impacted by adjacent, partially-reclaimed Upper Freeport coal spoils, adjacent to the wetland's entire western side. Cattails, sedges, sphagnum, and hair-cap mosses are the prevalent vegetation throughout this wetland.

Iron Pond is the youngest and smallest wetland in the study. Iron Pond is positioned on the southeastern side of Rt. 93 and steep, partially-reclaimed Upper Freeport coal spoils surround this wetland. This wetland is receiving AMD from multiple seeps along the base of the surrounding spoils (Figure 2). A small stream dissects this wetland before it spills into an orange pond. Drainage from Iron Pond is impeded by the presence of an abandoned railroad grade located on the other side of Rt. 93. The combination of the railroad grade and the presence of mine spoils appear to be the main factors affecting soil development in this wetland. Soils were described and sampled at 
five locations along one transect spanning the length of Iron Pond (Figure 2). Sampling locations represented the diverse vegetative populations of cattails, mosses, and sedges, which dominated the wetland fauna.

Railroad Grade is located on the northwestern side of Rt. 93 and is less impacted than Iron Pond and Narrow Wetland. Two transects were established across Railroad Grade, and soils were described and sampled at seven locations, three on one transect and four the other. Sediment and AMD from the Upper Freeport coal spoils located on the eastern end of Railroad Grade, directly across Rt. 93, appear to have impacted two or three of the seven sampling locations. The rest of the sampling locations do not appear to have been impacted by mining activities. The impacted sampling locations are identified as follows: 1-3, 1-4, and 2-1. An abandoned railroad grade is situated on the northwestern side of this wetland, and this grade is probably impeding drainage thus creating wetter conditions than would normally prevail in these soils. Mosses dominated this wetland and sparse populations of sedges and cattails were scattered throughout.

Elder Swamp, the largest wetland in the study area, has been classified as an area of Exceptional Resource Value and as a Wetland Special Area (West Virginia University 1995). Elder Swamp is situated on the northwestern side of Rt. 93. Five transects were established in the following areas: one each in an Alder Thicket, a Forested wetland, and a Scrub-Shrub wetland, and two in a Fen-Marsh wetland (Figure 3). Soils were described at three locations and sampled at two locations in the Alder Thicket, an area dominated by Alder. 


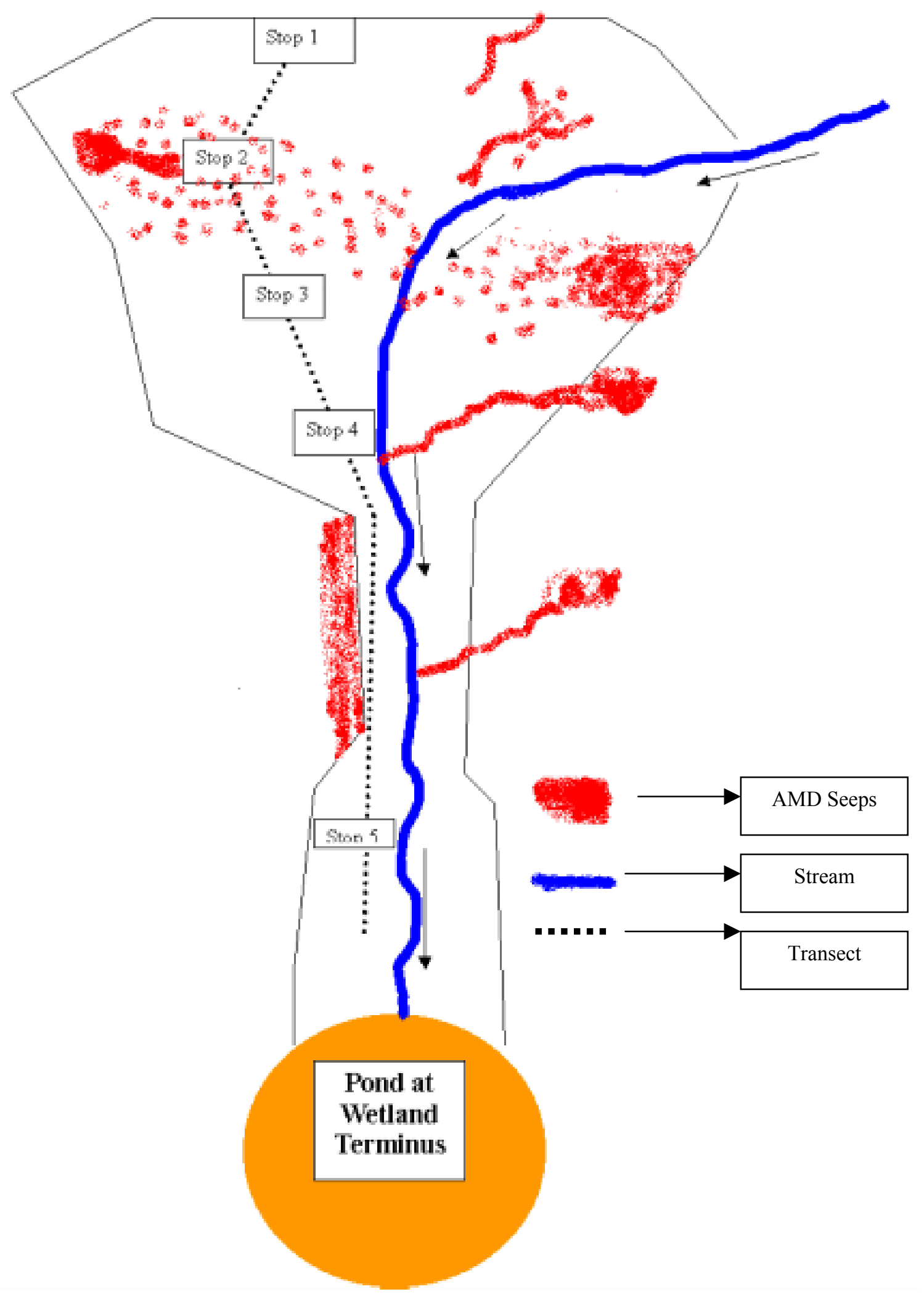

Figure 2. Map of Iron Pond Wetland in the Beaver Creek Watershed. AMD seeps, transect, sampling locations and stream identified. Not drawn to scale. 


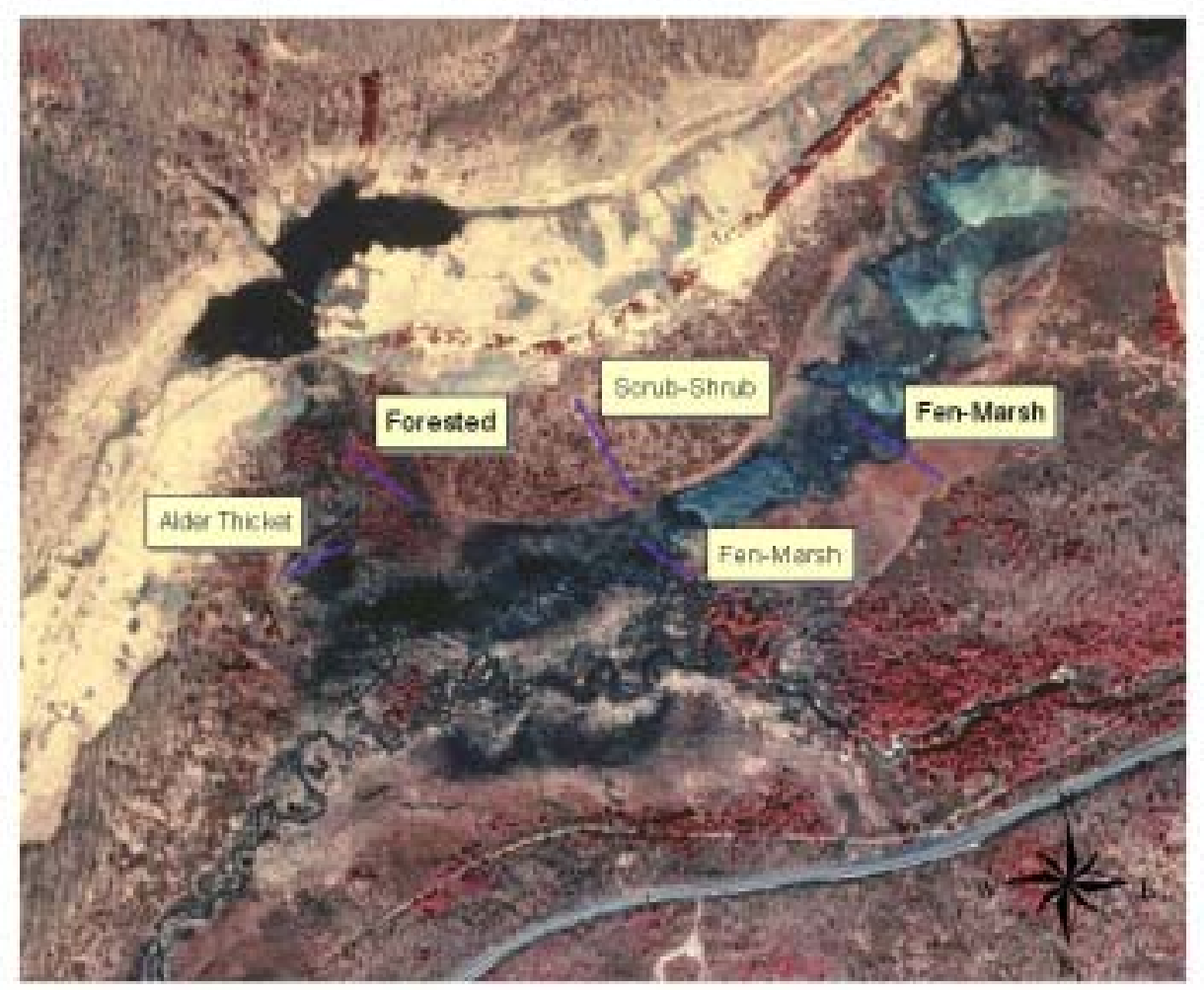

0.3 0 0.3 0.8 Miles

Figure 3. Aerial photograph of Elder Swamp depicting wetland habitats and transect locations. Transects are in purple.

The Forested Wetland is located in a thin stand of white pines slightly upslope from the Alder Thicket and the Fen-Marsh wetland, and the soils were described and sampled at two locations. The Scrub-Shrub wetland is located next to the forested wetland, and is covered with mosses, blueberry, and St Johns wort, and was also sampled and described at two locations. Soils in these latter two wetland types were similar in nature so they were grouped together for the purposes of this study and will be referred to as the Transitional Wetland. The Fen-Marsh area is the dominant ecosystem of Elder Swamp. In the Fen, sphagnum and hair-cap mosses cover the ground with a few sedges present. The fen borders the marsh, which makes up the central portion of Elder Swamp. The marsh is dominated by cattails growing on hummocks of peat. The fen sampling 
locations will be referred to as 1-1, 2-3, and 2-4, the marsh sampling locations will be referred to as 1-2 and 2-1, and 2-2. A braided stream that feeds nearby beaver ponds flows through the marsh area. Soils were described at six locations and sampled at four locations on the two transects.

Elder Swamp was assumed to be the non-impacted control wetland, but a coal refuse pile is positioned at the head of the Fen-Marsh area (Figure 1). Drainage from this refuse pile is treated to raise the $\mathrm{pH}$ and precipitate the iron out of solution before it reaches the wetland. Yet, sulfate is not be entirely removed in this treatment process, and some sulfate may be making its way into the Fen-Marsh wetland.

As previously mentioned, all wetlands are located along Rt. 93. Starting at the intersection of Rt. 93 and Rt. 32 heading east, Narrow Wetland is located $5.47 \mathrm{~km}(3.4$ miles) from the intersection on the southeastern side. Next, Railroad Grade is located 6.6 $\mathrm{km}$ (4.1 miles) from the intersection on the northwestern side of Rt. 93 followed by Iron Pond at $8.05 \mathrm{~km}$ (5.0 miles) from the intersection on the southeastern side of Rt 93. Elder Swamp is located approximately $190 \mathrm{~km}$ (12 miles) from the intersection on the northwestern side of Rt 93. Global Positioning coordinates for wetlands are located in soil profile conditions in Appendix A.

\section{Soil Sampling}

All soils were sampled and described in the summer of 2001 using the line transect method. In the AMD-impacted wetlands, transects were positioned through the center of the wetland. In Elder Swamp wetlands, transects were located with intent of sampling soils supporting certain vegetative communities. Spots were selected for sampling along each transect at every $50 \mathrm{~m}$, except for the Railroad Grade wetland. 
Sampling points in this wetland were selected at every $100 \mathrm{~m}$ so the wetland area was better represented. The location at each sampling point was determined with a Global Positioning System (GPS) unit and identifiable vegetation was recorded. Soils were exposed at every sampling point with a dutch auger and/or a peat sampler so that soils could be described according to standard soil survey procedures (Soil Survey Division Staff, 1993). The peat sampler was used primarily for organic layers and the dutch auger was used for mineral layers.

Soil sampling was done by both horizon and by depth based on field soil descriptions. All organic layers were sampled by horizon type, meaning Oi horizons were sampled together, Oe horizons sampled together, and Oa horizons were sampled together. Layers of the mineral subsurface soils were sampled at the following depths: $\mathrm{M} 1=0-10 \mathrm{~cm}, \mathrm{M} 2=10-30 \mathrm{~cm}, \mathrm{M} 3=30-60 \mathrm{~cm}$, and $\mathrm{M} 4=60-100 \mathrm{~cm}$. This method was used instead of sampling by horizon due to the problem associated with sampling the many thin layers found in the impacted soils and also to minimize the total sample load. Furthermore, this method still allowed us to observe changes in soil properties with depth. Following total carbon analysis, I found some inaccuracies in horizon/layer identification. At some sampling locations, organic layers had been described as mineral material and sampled accordingly. At other sampling locations, mineral layers were described as organic material and sampled accordingly. These errors were corrected by designating the first layer of mineral soil sampled at any one location as M1, regardless of depth, and then making the next layer M2 and so on. If the sampled M1 layer turned out to be organic, it was properly grouped with other organic layers in the study. I recommend that if this sampling strategy is to be used in the future, small soil samples should be removed when soils are described and analyzed for organic carbon before 
major sampling is completed. This will remove the possibility of errors in sampling soils organic materials separate form organic material.

Following the description of a soil, sampling depths were determined and fresh samples were removed. Samples were placed into zip lock bags, which were then immediately purged with $\mathrm{N}_{2}$ gas and sealed. Soil samples were then placed on ice in the field and then stored in a freezer within 24 hours of sampling to preserve sulfur in its field state.

\section{Sample Preparation for Laboratory Analysis}

The original intention of this study was to keep all soils frozen so they were preserved for the sulfur fractionation experiment. Problems encountered during the development of the sulfur fractionation procedure forced me to delay this experiment and change my original plan. To finish my research within a reasonable time, I had to remove sub samples of my frozen soils so additional laboratory analyses could begin. Sub samples were removed by partially thawing the frozen samples for 24 hours at $4{ }^{\circ} \mathrm{C}$ and then removing a small portion of partially thawed soil. The remaining soil was then refrozen and saved for the sulfur fractionation experiment. All sub samples were air

dried, passed through a 2-mm mesh sieve, and analyzed for the following chemical and physical properties except for sulfur fractions. When necessary, organic horizons containing large pieces of dead vegetation were ground to pass through the sieve.

\section{Particle Size}

Particle size was the only physical analysis conducted in this study. The pipette method (Soil Survey Staff, 1996) was used with a slight adjustment to the organic matter 
digestion procedure. Soils were treated with $10 \mathrm{ml}$ of $3 \%$ hydrogen peroxide at $85^{\circ} \mathrm{C}$ until fizzing ceased. This was a slower, but less demanding method for organic matter digestion. Additionally, sands were fractionated into five classes: very coarse (2.00-1.00 $\mathrm{mm})$, coarse $(1.00-0.5 \mathrm{~mm})$, medium $(0.50-0.25 \mathrm{~mm})$, fine $(0.25-0.106 \mathrm{~mm})$, and very fine $(0.106-0.053 \mathrm{~mm})$. This was accomplished by shaking sands for 3 minutes at 160 strokes per minute in a stack of increasing diameter sieves. (Soil Survey Staff, 1996).

\section{Chemical Analyses}

Soil $\mathrm{pH}$ was measured in a 1:1 soil to water suspension using a double junction silver/silver chloride $\mathrm{pH}$ probe on a $915 \mathrm{pH}$ meter (Method 8C1, Soil Survey Staff, 1996). Using the same soil samples from $\mathrm{pH}$ determinations, electrical conductivity was measured on a 1:2 soil to water suspension (Sarrantonio et al., 1996). Soil samples with high organic carbon content required additional water to be added to these suspensions. Total carbon, total sulfur and total nitrogen were determined using a LECO CNS 2000 analyzer. Extractable $\mathrm{Al}^{+3}$ was measured using a 45 -minute, $1 \mathrm{~N}$ potassium chloride extraction followed by $\mathrm{Al}^{+3}$ determination using an Atomic Absorption Spectrophotometer (Method 6G, 6G9,Soil Survey Staff, 1996). Exchangeable bases (Ca, $\mathrm{Mg}, \mathrm{Na}$, and $\mathrm{K})$ and cation exchange capacity were determined by a buffered $(\mathrm{pH} 7.0)$ ammonium acetate $\left(\mathrm{NH}_{4} \mathrm{OAc}\right)$ extraction (Method 6N, 6O, 6P, 6Q, Soil Survey Staff 1996). Potassium and Na were determined on the Atomic Absorption Spectrophotometer. Calcium and $\mathrm{Mg}$ were determined on an Inductively Coupled Plasma analyzer. Cation exchange capacity was determined by measuring the absorbed $\mathrm{NH}_{4}{ }^{+}$ions on a Kjeldahl nitrogen analyzer. 


\section{Sulfur Fractionation Procedure}

Sulfur was fractionated into $\mathrm{SO}_{4}-\mathrm{S}, \mathrm{FeS}-\mathrm{S}, \mathrm{FeS}_{2}$, and organic sulfur for all frozen soil samples. Methods reported by Urlich et al. (1997) and Kennedy et al. (1999), were used as a basis for developing this procedure. To obtain $\mathrm{FeS}$ and $\mathrm{FeS}_{2}$, the frozen soils were kept at $4^{\circ} \mathrm{C}$ until thawed and then three sub samples were removed. The first subsample was used to obtain moisture content. The second was extracted with sodium phosphate to obtain $\mathrm{SO}_{4}-\mathrm{S}$, which was measured spectrophotometrically on a Lachat flow injection analyzer (FIA). The third subsample was placed in a 60-ml glass vial to obtain FeS-S and $\mathrm{FeS}_{2}-\mathrm{S}$. Next, $2.5 \mathrm{ml}$ of deoxygenated $1 \mathrm{M}$ sodium hydroxide $(\mathrm{NaOH})$ was injected into a 6-ml plastic vial that was fitted with a rubber o-ring. The vial was then placed in the 60-ml glass vial that contained the soil sample. A lid with a Teflon coated septa was placed on the vial, and the vial was deoxygenated for 60 seconds with nitrogen gas $\left(\mathrm{N}_{2}\right)$ at 25 psi. Following this, 3-5 $\mathrm{ml}$ of deoxygenated $6 \mathrm{~N}$ hydrochloric acid $(\mathrm{HCl})$ were injected into the vial and the vial was placed on an oscillating shaker at $130 \mathrm{rpm}$ for 48 hours. All sulfide released during this time was trapped in the $\mathrm{NaOH}$ solution as sodium sulfide $\left(\mathrm{Na}_{2} \mathrm{~S}\right)$, and was considered to be in the form of FeS. This was not confirmed, so for this study all sulfide detected in this step will be operationally defined as acid volatile sulfides (AVS).

The vial was opened after 48 hours under $\mathrm{N}_{2}$ gas flow, never allowing the soil to be exposed to atmospheric conditions, and the $\mathrm{NaOH}$ trap was removed. The glass vial was centrifuged, and the supernatant was collected for total Fe analysis. A fresh $\mathrm{NaOH}$ trap was then placed in the vial, and the vial was degassed for 60 seconds with $\mathrm{N}_{2}$ at 25 psi. This time 2-3 $\mathrm{ml}$ of deoxygenated concentrated $\mathrm{HCl}$ were injected into the vial and 
2-3 $\mathrm{ml}$ of reduced chromium $\left(\mathrm{Cr}^{2+}\right)$ in the form of $1 \mathrm{M}$ chromic chloride were injected into the vial. The vial was again placed on the oscillating shaker for 48 hours at $130 \mathrm{rpm}$. After 48 hours of agitation the traps were removed and the vial was centrifuged. Sulfide collected in this trap was assumed to be in the form of $\mathrm{FeS}_{2}$, but this was not confirmed, so these sulfides will be referred to as chromium reducible sulfides (CRS). The supernatant was collected and mixed with the supernatant from the first step, so total Fe could be analyzed via the Inductively Coupled Plasma spectrometer. The $\mathrm{NaOH}$ traps were brought to a known volume, and were analyzed spectrophotometrically for $\mathrm{Na}_{2} \mathrm{~S}$ on the FIA using the Zellwegar Analytics INC. QuickChem method developed by Diamond (2001). The sodium phosphate extractions also were analyzed on the FIA according to the method developed by Egan (1998).

Lastly, organic sulfur was obtained by subtracting the sum of $\mathrm{SO}_{4}-\mathrm{S} \mathrm{FeS-S}$, and $\mathrm{FeS}_{2}-\mathrm{S}$ from the total sulfur value. Any elemental sulfur present in these samples would therefore be included in the organic sulfur form.

To test the sulfur fractionation procedure crystalline standards of $\mathrm{FeS}$ and $\mathrm{FeS}_{2}$ were analyzed. Standards containing both $\mathrm{FeS}$ and $\mathrm{FeS}_{2}$ were analyzed in triplicate. The mean recovery rate for FeS was $96.7 \%$ with a standard deviation of 2.8 . For $\mathrm{FeS}_{2}$, the mean recovery rate was $90.4 \%$ with a standard deviation of 1.2 . In addition, standards containing only $\mathrm{FeS}_{2}$ were analyzed to verify that $\mathrm{FeS}_{2}$ was not recovered during the AVS step of the procedure. Less then $1 \%$ of the $\mathrm{FeS}_{2}$ was recovered in this step. Triplicate mineral soil samples were also spiked with $\mathrm{FeS}$ and $\mathrm{FeS}_{2}$. The recovery rates for FeS declined to 20 to $50 \%$, while the recovery of $\mathrm{FeS}_{2}$ remained about the same. The same phenomena occurred with organic soils as well. No conclusions were reached as to why FeS recovery was limited in the spiked soil samples. It was believed that the procedure 
would still recover the majority of FeS, since FeS does not naturally exist in the crystalline form of the standard.

\section{Field Analyses-Redox Potential}

In the fall of 2001, platinum-tipped redox electrodes were constructed according to instructions provided by Faulkner et al. (1989). In December 2001, these electrodes were placed in the ground and the first measurements were taken 24 hours after initial placement. Redox measurements were made in the field for one year using a portable voltmeter and a saturated calomel reference electrode. Meter readings were adjusted by adding $+200 \mathrm{mV}$ so redox potential was based on the standard hydrogen reference electrode instead of the saturated calomel electrode. At each redox sampling location, six probes were permanently placed at a $20-\mathrm{cm}$ depth and six at a $10-\mathrm{cm}$ depth. The average of the six electrodes was used as a single redox value. Measurements were taken at three locations in each of the following three wetlands: Railroad Grade, Iron Pond, and Elder Swamp. In Railroad Grade, one location (stop 1) was AMD-impacted and the other two locations were unimpacted. In Elder Swamp, measurements were taken from soils in the fen, marsh and scrub-shrub wetlands. At Iron Pond, measurements were taken from three locations representing three different vegetative communities. All sites in Iron Pond were considered AMD-impacted.

Redox probes at the 10-cm depth were placed in an A horizon in the scrub-shrub site and in organic horizons at all other sites. At the $20-\mathrm{cm}$ depth, the probes were placed in a B horizon at the scrub-shrub site and in A horizons at Iron Pond stop 5 and Railroad Grade Stop 1. At all other sites, the 20-cm probes were placed in organic horizons. 
Soil $\mathrm{pH}$ also was measured at both 10 and $20 \mathrm{~cm}$ when each of the monthly redox readings were taken. To simplify interpretation of Eh readings and comparisons among wetlands, redox potentials were adjusted to represent Eh at $\mathrm{pH}$ 7. This was done by subtracting $59 \mathrm{mV}$ for each unit of decrease below pH 7 (Karathanasis et al., 2003). Unadjusted readings and field $\mathrm{pH}$ measurements are presented in tabular form in Appendix C. 


\section{RESULTS AND DISSCUSSION}

\section{Soil Morphology}

Narrow Wetland -The total mean thickness of organic horizons for Narrow Wetland was $16 \mathrm{~cm}$ with a range of 3 to $42 \mathrm{~cm}$ (Table 1). The mean thickness of the Oi horizon was $12 \mathrm{~cm}$ with a range of 3 to $42 \mathrm{~cm}$ (Table 1), and this horizon consisted mainly of sphagnum moss fibers or sedges (Appendix A). Oe horizons were described at only three sampling locations and the mean thickness was $10 \mathrm{~cm}$ with a range of 6 to $17 \mathrm{~cm}$ (Table 1). Based upon these data, no soil described in this wetland would be classified as a Histosol. For a soil to be considered a Histosol there must be at least $40 \mathrm{~cm}$ of organic material present, or at least $60 \mathrm{~cm}$ if the bulk density is less than $0.1 \mathrm{~g} \mathrm{~cm}^{-3}$ (Soil Survey Staff, 1999). For soil material to be considered organic it must contain 12 to $18 \%$ organic carbon, with the range dependent on clay content (Soil Survey Staff, 1999). Though not a Histosol, a soil can have a histic epipedon if $20 \mathrm{~cm}$ organic material is

present at the surface (Soil Survey Staff, 1998). Some soils in Narrow Wetland contained Histic epipedons.

No Oa horizons were described in Narrow Wetland, but A horizons were described at every sampling location (Appendix A). Lack of Oa horizons indicates that the organic material is relatively young and is not well decomposed. This wetland most likely became saturated following the construction of Rt. 93, about 25 years ago. This explains the presence of thick Oi and Oe surface horizons, but no Oa horizons. Under recent saturated conditions organic matter will accumulate but it will not be in the welldecomposed form. Furthermore, the presence of well developed A horizons is an 
Table 1. Average thickness of individual organic horizons (Oi, Oe, and $\mathrm{Oa}$ ), total thickness of the organic layer, and solum thickness for wetland soils in the Beaver Creek Watershed, WV. Values expressed as a mean of all soil sampling locations in each wetland, with $\mathrm{n}$ representing the number of soil sampling locations that contained the horizon type.

\begin{tabular}{|c|c|c|c|c|c|c|c|c|c|c|c|c|c|c|c|}
\hline \multirow[t]{2}{*}{ Site } & \multicolumn{3}{|c|}{ Oi } & \multicolumn{3}{|c|}{$\mathrm{Oe}$} & \multicolumn{3}{|c|}{$\mathrm{Oa}$} & \multicolumn{3}{|c|}{ Organic Layer } & \multicolumn{3}{|c|}{ Solum } \\
\hline & $\mathrm{n}$ & Mean & Range & $\mathrm{n}$ & Mean & Range & $\mathrm{n}$ & Mean & Range & $n$ & Mean & Range & $\mathrm{n}$ & Mean & Range \\
\hline & \multicolumn{3}{|c|}{$\mathrm{Cm}$} & \multicolumn{3}{|c|}{$\mathrm{cm}$} & \multicolumn{3}{|c|}{$\mathrm{cm}$} & \multicolumn{3}{|r|}{$\mathrm{cm}$} & \multicolumn{3}{|r|}{$\mathrm{cm}$} \\
\hline $\begin{array}{l}\text { Narrow } \\
\text { Wetland }\end{array}$ & 5 & 12 & $3-42$ & 3 & 10 & $6--17$ & 0 & -- & -- & 6 & 16 & $3--42$ & 6 & 39 & $10--69$ \\
\hline Iron Pond & 5 & 18 & $7-23$ & 1 & 2 & -- & 0 & -- & -- & 5 & 19 & 9--23 & 5 & 36 & 13--75 \\
\hline Railroad Grade & 7 & 16 & $7-33$ & 7 & 14 & $7--48$ & 7 & 14 & $5--24$ & 7 & 33 & $17--54$ & 7 & 64 & $43--100$ \\
\hline Alder Thicket & 0 & -- & -- & 3 & 4 & $3--7$ & 2 & 16 & $16--16$ & 3 & 20 & $7--34$ & 3 & 101 & $94--108$ \\
\hline $\begin{array}{l}\text { Transitional } \\
\text { Wetland }\end{array}$ & 0 & -- & -- & 2 & 5 & $4--7$ & 3 & 5 & $2--9$ & 4 & 7 & $4--9$ & 4 & 94 & $80--123$ \\
\hline Fen-Marsh & 4 & 13 & $4-23$ & 6 & 18 & 7--38 & 6 & 70 & 57--99+ & 6 & 98 & $73--120+$ & 6 & 104 & $84--120+$ \\
\hline
\end{tabular}

indicator of soils, which have developed under non-saturated conditions. The A horizons in Narrow Wetland most likely developed before Rt. 93 was constructed when the soils were drier.

The subsurface mineral material was composed of A horizons overlying either Bg and $\mathrm{Cg}$ horizons or just $\mathrm{Cg}$ horizons (Appendix A). At stop 6, buried horizons were described at $60 \mathrm{~cm}$ (Appendix A). Stop 6 was the closest sampling location to Rt. 93 and materials have probably been accumulating there since the construction of the road, which caused the original soil to become buried. Lastly, in four of the six sampling locations bedrock was encountered at depths ranging from $45 \mathrm{~cm}$ to $100 \mathrm{~cm}$ (Appendix A). 
Iron Pond - At each sampling location in Iron Pond there was an Oi horizon consisting mainly of moss fibers. The mean thickness of the Oi horizons $(18 \mathrm{~cm})$ was the highest for any wetland in the study (Table 1). No Oa horizons were described in Iron Pond and only one soil sampling location contained an Oe horizon (Table 1). Drainage from Iron Pond is impeded by the presence of an abandoned railroad grade located on the opposite side of Rt. 93. Since drainage is impeded, Iron Pond acted as sediment trap for mine sediments. The sediments, washed in from surrounding mine spoils, have formed the underlying mineral soil layers. This subsurface mineral material consists mainly of massive $\mathrm{C}$ horizons (Appendix A). The soils in Iron Pond are young and undeveloped. Since mainly Oi horizons were present at the surface, the mean total thickness of the organic layer was similar to the mean thickness of the Oi horizon (Table 1). No Histic epipedons were described in Iron Pond.

The solum is the portion of the soil that has undergone some degree of change. The solum includes all soil horizons except $\mathrm{C}$ horizons. The mean solum thickness of 36 $\mathrm{cm}$ in Iron Pond was the least of any wetland, indicating that the soil is pedogenically the youngest in the study (Table 1).

Railroad Grade - In Railroad Grade the mean thickness of the organic layer $(33 \mathrm{~cm})$ was second only to the Fen-Marsh (Table 1), but did not meet the requirement for Histosols. Based upon these data Railroad Grade does contain a Histic epipedon in some spots. Organic layer thickness ranged from 17 to $54 \mathrm{~cm}$ (Table 1), with the lower values observed in the AMD-impacted sampling locations. The impacted soils are subjected to an input of sediments and AMD from nearby mine spoils, two factors that inhibit organic horizon development via limiting plant growth. Soils were described and sampled at 
seven locations in Railroad Grade and all had Oi, Oe, and Oa horizons (Table 1). The Oa and Oe horizons each had a mean thickness of $14 \mathrm{~cm}$, which indicates that organic materials have been accumulating much longer in this wetland than in Iron Pond and Narrow Wetland. The mean solum thickness $(64 \mathrm{~cm})$ was greater than Narrow Wetland and Iron Pond but about half that of the wetlands in Elder Swamp (Table 1). An abandoned railroad grade is situated along the entire length of the northeastern border of this wetland. This railroad grade has slowed drainage and changed the wetland hydrology, similar to the effects of Rt. 93 on Narrow Wetland and Iron Pond. Yet, the presence of well developed Oa and Oe horizons indicates that this area was wet and accumulating organic material prior to the construction of the railroad grade.

Stops 3 and 4 on transect 1 and stop 1 on transect 2 contained buried organic horizons (Appendix A). These sampling points were located in the impacted eastern portion of this wetland. The buried horizons resulted from a combination of the abandoned railroad grade and the input of sediments from the nearby mine spoils. The railroad grade acted as a trap for the sediments washing in from the spoils, thereby allowing the original soils to become buried. Soils at the remaining sampling locations were unaffected by these processes. The non-impacted sampling locations contained either $\mathrm{Cg}$ or Bg horizons in the subsurface mineral material (Appendix A).

Alder Thicket - Oe horizons were described at every location in the Alder Thicket and Oa horizons were described at two sampling locations (Table 1). A Histic epipedon was described at one sampling location (Appendix A). Mean thickness of the Oa was $16 \mathrm{~cm}$ and for the Oe it was $3 \mathrm{~cm}$ (Table 1). Fibric (Oi) horizons were not described in this wetland. These data indicate that the organic material in the Alder Thicket is subjected to 
high decomposition rates, which resulted in the formation of well-decomposed Oa horizons. The lack of any Oi material supports these findings. When soils in this wetland were sampled and described, the water table was $20 \mathrm{~cm}$ below the surface. Therefore, this wetland is probably not saturated at the surface year round. The mean solum thickness was $101 \mathrm{~cm}$, which indicates that soil in this wetland is more pedogenically developed then soils in Iron Pond, Narrow Wetland, and Railroad Grade (Table 1).

The mineral material in Alder Thicket consisted of thick silty clay loam and silt loam Bg horizons overlying Cg horizons (Appendix A). Despite high clay content in this mineral material, there were no argillic horizons described in this wetland. The clay in these horizons is not a result of illuvial processes but rather a result of alluvial deposition.

Transitional Wetland - Forested and Scrub-Shrub wetlands are never saturated at the surface throughout the year, as indicated by the presence of a thin, well-decomposed, organic layer $(7 \mathrm{~cm})$ (Table 1). The organic horizons in these soils are all either Oa or Oe. As in the Alder Thicket, lack of Oi horizons indicates that organic materials are decomposed at a rapid rate. Soils in these wetlands meet hydric soil criteria but are also the driest in the study. Drier conditions favor rapid decomposition of organic materials, which resulted in the thin organic layer. The mean solum thickness $(106 \mathrm{~cm})$ is the highest in the study, which indicates that the soils in these wetlands are well developed (Table 1). The solum mostly consists of thick Bt, Bx, and Btx horizons (Appendix A). The $\mathrm{Bt}$ is a horizon of clay accumulation and the $\mathrm{Bx}$ is a fragipan, which is a loamy layer that is dense, brittle, and restricts root and water movement. The Btx is a combination of 
the two different horizon types. The fragipan is responsible for perching the water table, which in turn has created the hydric soil conditions.

Fen-Marsh - The mean thickness of the organic layer in the Fen-Marsh was $98 \mathrm{~cm}$ with a range of 73 to $120 \mathrm{~cm}$ (Table 1). This is by far the thickest organic layer in the study, and soils in this wetland would be classified as Histosols. In most of the described soils, no mineral material was observed therefore the organic material might extend deeper than $120 \mathrm{~cm}$ from the surface. Mineral material was described at two locations (Appendix A). In one it was a silty clay loam $\mathrm{C}$ horizon and at the other location it consisted of both $\mathrm{B}$ and $\mathrm{C}$ horizons. The organic material consisted of thinner Oe and Oi horizons near or at the surface, and thicker well decomposed Oa horizons throughout the subsurface. The mean thickness of the Oa horizons was $70 \mathrm{~cm}$, by far the thickest in any wetland (Table 1). These data indicate a long period of organic matter accumulation in this wetland. The mean solum thickness was $104 \mathrm{~cm}$, the second largest in the study (Table 1). These soils appear to be some of the oldest soils in the study.

\section{Particle Size Distribution}

The average textural class in Narrow Wetland was either silt loam or silty clay loam (Table 2). The range of textural classes also included loams and silty clays (Appendix B). Average sand content increased with depth in Narrow Wetland and average clay content decreased with depth. Silt content remained relatively steady at about $50 \%$. 
Table 2. Average particle size distribution and average textural classes for wetland soils in the Beaver Creek Watershed, WV. Mineral layers sampled by depth with M1 being the uppermost layer and M4 being the lowest layer.

\begin{tabular}{|c|c|c|c|c|c|c|c|c|}
\hline & & \multicolumn{2}{|c|}{ Sand } & \multicolumn{2}{|c|}{ Silt } & \multicolumn{2}{|c|}{ Clay } & \multirow[t]{3}{*}{ Textural Class ${ }^{2}$} \\
\hline \multirow{2}{*}{\multicolumn{8}{|c|}{ AMD-Impacted Wetlands }} & \\
\hline & & & & & & & & \\
\hline Narrow Wetland & $\mathrm{n}^{1}$ & Average & Range & Average & Range & Average & Range & \\
\hline Oi & 3 & -- & -- & -- & -- & -- & -- & -- \\
\hline $\mathrm{Oe}$ & 1 & -- & -- & -- & -- & -- & -- & -- \\
\hline M1 & 3 & 5.0 & $1.2--12.1$ & 56.3 & $51.0--59.8$ & 38.7 & 29.6--47.5 & $\mathrm{SiCL}$ \\
\hline M2 & 3 & 18.8 & $7.2--18.0$ & 55.3 & $46.9--64.7$ & 25.9 & 22.1--28.1 & $\mathrm{SiL}$ \\
\hline M3 & 3 & 29.1 & $19.5--36.9$ & 50.8 & $42.1--58.9$ & 20.1 & 17.8--21.6 & SiL \\
\hline \multicolumn{9}{|l|}{ Iron Pond } \\
\hline Oi & 5 & -- & -- & -- & -- & -- & -- & -- \\
\hline $\mathrm{Oe}$ & 1 & -- & -- & -- & -- & -- & -- & -- \\
\hline M1 & 5 & 12.3 & $1.0--27.4$ & 67.3 & 47.7--93.3 & 20.5 & 6.1--33.8 & SiL \\
\hline M2 & 5 & 33.4 & $3.4--66.3$ & 43.9 & 21.2--60.2 & 22.7 & $12.5--36.4$ & $\mathrm{~L}$ \\
\hline M3 & 5 & 27.4 & 4.1--66.0 & 48.1 & 20.2--66.4 & 24.5 & $13.7--32.1$ & $\mathrm{~L}$ \\
\hline M4 & 3 & 26.9 & 8.3--50.1 & 45.4 & $35.0--46.5$ & 27.7 & 14.9--36.9 & $\mathrm{CL}$ \\
\hline \multicolumn{9}{|l|}{ Railroad Grade } \\
\hline Oi & 7 & -- & -- & -- & -- & -- & -- & -- \\
\hline Oe & 7 & -- & -- & -- & -- & -- & -- & -- \\
\hline $\mathrm{Oa}$ & 5 & -- & -- & -- & -- & -- & -- & -- \\
\hline M1 & 7 & 7.9 & $0.5--16.3$ & 61.6 & 53.8--86.1 & 30.6 & 7.6--41.8 & $\mathrm{SiCL}$ \\
\hline M2 & 7 & 9.6 & $0.6--21.4$ & 57.8 & 46.4--64.7 & 32.6 & $15.7--38.7$ & $\mathrm{SiCL}$ \\
\hline M3 & 4 & 21.4 & 2.6--61.6 & 59.7 & 25.6--67.5 & 18.9 & $11.2--41.5$ & SiL \\
\hline M4 & 2 & 11.7 & $0.2--23.1$ & 74.4 & 59.2--89.7 & 13.9 & $10.1--17.8$ & SiL \\
\hline \multicolumn{9}{|c|}{ Non-Impacted Wetlands } \\
\hline \multicolumn{9}{|l|}{ ES: Alder Thicket } \\
\hline Oe & 2 & -- & -- & -- & -- & -- & -- & -- \\
\hline $\mathrm{Oa}$ & 2 & -- & -- & -- & -- & -- & -- & -- \\
\hline M1 & 2 & 2.7 & $1.8--3.6$ & 61.6 & 59.3--63.9 & 35.7 & 32.6--38.9 & $\mathrm{SiCL}$ \\
\hline M2 & 2 & 3.5 & $3.4--3.7$ & 60.5 & 59.6--61.4 & 36.0 & $35.2--36.7$ & $\mathrm{SiCL}$ \\
\hline M3 & 2 & 23.9 & $14.0--33.8$ & 52.6 & $45.6--59.6$ & 23.5 & 20.6--26.4 & SiL \\
\hline \multicolumn{9}{|c|}{ ES: Transitional Wetland } \\
\hline Oe & 2 & -- & -- & -- & -- & -- & -- & - \\
\hline $\mathrm{Oa}$ & 3 & -- & -- & -- & -- & -- & -- & -- \\
\hline M1 & 4 & 17.1 & 3.7--37.6 & 59.4 & $45.3--65.6$ & 23.5 & $17.1--35.1$ & SiL \\
\hline M2 & 4 & 25.0 & $15.3--40.8$ & 48.8 & $36.4--59.6$ & 26.2 & 22.8--28.5 & $\mathrm{L}$ \\
\hline M3 & 4 & 35.5 & $27.3--47.1$ & 40.7 & $32.9--47.3$ & 23.8 & 20.0--28.0 & $\mathrm{L}$ \\
\hline M4 & 4 & 38.4 & $30.0--53.6$ & 43.0 & $31.6--46.9$ & 18.6 & $14.8--23.4$ & L \\
\hline \multicolumn{9}{|l|}{ ES: Fen-Marsh } \\
\hline Oi & 3 & -- & -- & -- & -- & -- & -- & -- \\
\hline Oe & 4 & -- & -- & -- & -- & -- & -- & -- \\
\hline $\mathrm{Oa}$ & 4 & -- & -- & -- & -- & -- & -- & -- \\
\hline M1 & 2 & 18.2 & $9.3--27.1$ & 53.2 & $47.1--59.3$ & 28.6 & $13.7--43.6$ & $\mathrm{SiCL}$ \\
\hline M2 & 1 & 78.5 & -- & 16.9 & -- & 4.6 & -- & SL \\
\hline M3 & 1 & 50.7 & -- & 39.7 & -- & 9.7 & -- & $\mathrm{L}$ \\
\hline
\end{tabular}

1- $n=$ the number of sampling locations that contained that layer type.

${ }^{2}$-CL=Clay Loam, L=Loam, SiCL=Silty Clay Loam, SiL=Silt Loam, and SL=Sandy Loam. 
In Iron Pond, particle size distribution varied greatly (Appendix B). This is most likely related to the variability in the sediments washed in from the surrounding mine spoils. Looking at the data for individual sampling locations it was observed that sand decreased, and clay and silt increased, when moving from the head of Iron Pond (stop1) toward the terminus (Stop 5) (Appendix B). This is a result of the settling of coarser material out of water carrying sediments through the wetland.

As with Iron Pond, Railroad Grade also displayed variability in particle size distribution (Appendix B). The average textures were either silt loams or silty clay loams (Table 2), but at individual sampling locations silts, loams, silty clays, and sandy loams were observed (Appendix B). In general, mineral material in this wetland was composed mostly of silt.

Mineral material in Alder Thicket displayed little variability in particle size distribution (Appendix B). The average sand content was low in the M1 and M2 layers $(<3.5 \%)$ and increased sharply in the M3 layer (23.9\%) (Table 2). Average silt and clay were higher in the M1 and M2 layers and decreased slightly in the M3 layer (Table 2). The average textural class was silty clay loam in the M1 and M2 layers and silt loam in the M3 layer.

The average textural class for the M1 layer in the Transitional Wetland was silt loam and for all other layers it was loam (Table 2). Little variability in particle size distribution was observed between individual sampling locations (Appendix B). The loamy textures observed in these soils are a key property for fragipan development, a layer that was described in these soils. 


\section{Chemical Properties}

Soil pH -The Oi layer in Iron Pond had the lowest average pH (4.2) of any Oi layer in the study (Table 3). Five sites were sampled in Iron Pond and all five contained Oi layers. The $\mathrm{pH}$ of the Oi layer at each of the individual sampling locations in Iron Pond showed the following decrease in $\mathrm{pH}$ when moving from the head (relatively unimpacted section) to the terminus of this wetland: $6.0,5.0,3.4,3.6,3.2$ (Appendix C). This indicates that Iron Pond is retaining hydrogen proton acidity generated from the precipitation of iron hydroxides as the AMD flows through the wetland.

As indicated by the ranges, the $\mathrm{pH}$ of the organic layers in Railroad Grade was variable (Table 3). However, when looking at the $\mathrm{pH}$ of the individual sampling locations in Railroad Grade, I observed that the lower $\mathrm{pH}$ values occurred in the organic layers of the non-impacted portion, and the higher $\mathrm{pH}$ values occurred in the organic layers of the AMD-impacted portion (Appendix C). As compared to Iron Pond, less iron hydroxides were observed in the AMD-impacted portion of Railroad Grade; therefore, the hydrogen proton generation via iron hydroxide precipitation is not as influential on soil $\mathrm{pH}$ in the AMD-impacted portion of Railroad Grade. Furthermore, the generation of alkalinity from reduction of $\mathrm{Fe}$ and $\mathrm{S}$ in the AMD-impacted area may explain the higher $\mathrm{pH}$ values observed in the AMD-impacted portion of Railroad Grade (Vile and Wieder, 1993).

In the Fen-Marsh wetland, the average $\mathrm{pH}$ of the Oi layer was 4.5 with a range of 3.8-4.9 (Table 3). The average $\mathrm{pH}$ of the Oe layer was 4.8 with a range of 3.9 to 5.7 , and the average $\mathrm{pH}$ of the Oa layer was 4.7 with a range of 3.8 to 5.9 (Table 3 ). The wide range in $\mathrm{pH}$ of the organic layers in the Fen-Marsh is related to differences in the 
Table 3. Average $\mathrm{pH}$, electrical conductivity (Ec), extractable aluminum (Al), and total iron (Fe) for wetland soils In the Beaver Creek Watershed, WV. Organic horizon sampled by type, mineral layers sample by depth with M1 being the uppermost layer and M4 being the lowest layer.

\begin{tabular}{|c|c|c|c|c|c|c|c|c|c|c|c|c|c|}
\hline & & \multicolumn{3}{|c|}{$\mathrm{pH}$} & \multirow{2}{*}{\multicolumn{3}{|c|}{$\begin{array}{c}\mathrm{Ec} \\
\mathrm{dS}^{-}\end{array}$}} & \multicolumn{3}{|c|}{$\mathrm{Al}$} & \multicolumn{3}{|c|}{$\mathrm{Fe}$} \\
\hline & & & & & & & & & $\mathrm{cmol}_{\mathrm{C} \mathrm{kg}}{ }^{-1}$ & & \multicolumn{3}{|c|}{$u_{\mathrm{mol} \mathrm{g}}{ }^{-1}$ dry mass } \\
\hline \multicolumn{14}{|c|}{ AMD-Impacted Wetlands } \\
\hline & $\mathrm{n}^{*}$ & Average & Range & Stdev & Average & Range & Stdev & Average & Range & Stdev & Average & Range & Stdev \\
\hline \multicolumn{14}{|c|}{ Narrow Wetland } \\
\hline Oi & 3 & 5.1 & $4.1--5.9$ & 0.9 & 0.19 & $0.17--0.20$ & 0.0 & 1.1 & $0.0--2.5$ & 1.3 & 1504 & $313--2980$ & 1356 \\
\hline Oe & 1 & 5.6 & -- & -- & 0.22 & -- & -- & 0.0 & -- & -- & 775 & -- & -- \\
\hline M1 & 3 & 4.9 & $4.5--5.6$ & 0.6 & 0.19 & $0.05--0.28$ & 0.1 & 2.6 & $0.0--6.8$ & 3.7 & 199 & $109--217$ & 83 \\
\hline M2 & 3 & 5.0 & $4.5--5.7$ & 0.6 & 0.16 & $0.08--0.25$ & 0.1 & 2.1 & $0.0--5.7$ & 3.1 & 105 & $46--215$ & 95 \\
\hline \multirow[t]{2}{*}{ M3 } & 3 & 5.2 & $4.6--6.1$ & 0.7 & 0.16 & $0.08-0.26$ & 0.1 & 1.4 & $0.0--3.6$ & 1.9 & 66 & 51--84 & 17 \\
\hline & \multicolumn{13}{|c|}{ Iron Pond } \\
\hline Oi & 5 & 4.2 & $3.2--6.0$ & 1.2 & 0.21 & $0.10--0.37$ & 0.1 & 3.9 & $0.0--10.9$ & 4.5 & 1588 & 644--3709 & 1269 \\
\hline Oe & 1 & 6.0 & -- & -- & 0.08 & -- & -- & 0.0 & -- & -- & 1079 & -- & -- \\
\hline M1 & 5 & 5.0 & $4.7--5.8$ & 0.4 & 0.22 & $0.10--0.29$ & 0.1 & 0.4 & $0.0--1.1$ & 0.4 & 763 & 315--1298 & 374 \\
\hline M2 & 5 & 4.7 & $4.5--5.1$ & 0.2 & 0.11 & $0.08--0.20$ & 0.0 & 0.7 & $0.3--1.4$ & 0.4 & 480 & 334--694 & 132 \\
\hline M3 & 5 & 4.5 & $4.0--4.9$ & 0.4 & 0.10 & $0.06--0.13$ & 0.0 & 1.2 & $0.2--3.4$ & 1.3 & 428 & $397--462$ & 24 \\
\hline M4 & 3 & 4.4 & $4.2--4.6$ & 0.2 & 0.09 & $0.05--0.12$ & 0.0 & 1.1 & $0.8--1.3$ & 0.2 & 533 & 499--566 & 33 \\
\hline \multicolumn{14}{|c|}{ Railroad Grade } \\
\hline Oi & 7 & 4.6 & $3.8--5.9$ & 0.8 & 0.13 & $0.05--0.23$ & 0.1 & 7.1 & $2.5--22.1$ & 6.8 & 521 & $40--1350$ & 578 \\
\hline $\mathrm{Oe}$ & 7 & 4.5 & $3.8--5.5$ & 0.5 & 0.13 & $0.08--0.20$ & 0.0 & 6.7 & $0.8--15.5$ & 5.8 & 467 & $101--1260$ & 428 \\
\hline $\mathrm{Oa}$ & 5 & 4.3 & $3.9--4.5$ & 0.3 & 0.11 & $0.08--0.15$ & 0.0 & 11.9 & 5.6--21.4 & 6.7 & 180 & 63--380 & 127 \\
\hline M1 & 7 & 4.2 & $3.9--4.7$ & 0.2 & 0.11 & $0.07--0.21$ & 0.0 & 8.2 & 1.8--20.5 & 6.2 & 360 & 77--1119 & 354 \\
\hline M2 & 7 & 4.2 & $3.9--4.4$ & 0.2 & 0.20 & $0.06--0.77$ & 0.3 & 6.6 & $1.2--19.4$ & 6.0 & 265 & $125--533$ & 147 \\
\hline M3 & 4 & 4.4 & $4.3--4.9$ & 0.3 & 0.13 & $0.07--0.28$ & 0.0 & 4.2 & $0.7--10.6$ & 4.6 & 472 & $58--257$ & 242 \\
\hline M4 & 2 & 4.3 & -- & 0.0 & 0.17 & $0.12--0.22$ & 0.1 & 4.1 & $3.9--4.3$ & 0.3 & 543 & 428--973 & 608 \\
\hline \multicolumn{14}{|c|}{ Non-Impacted Wetlands } \\
\hline \multicolumn{14}{|c|}{ ES: Alder Thicket } \\
\hline Oe & 2 & 5.4 & $4.8--5.9$ & 0.8 & 0.13 & $0.13--0.14$ & 0.0 & 1.2 & $0.1--2.4$ & 1.7 & 685 & $522-848$ & 230 \\
\hline $\mathrm{Oa}$ & 2 & 5.4 & 5.0--5.8 & 0.6 & 0.09 & $0.08--0.10$ & 0.0 & 1.2 & $0.3--1.9$ & 1.1 & 188 & 71--305 & 166 \\
\hline M1 & 2 & 4.8 & 4.7---4.8 & 0.1 & 0.07 & $0.05--0.11$ & 0.0 & 4.7 & 7.2--10.2 & 2.1 & 33 & $31--34$ & 3 \\
\hline M2 & 2 & 4.7 & -- & 0.0 & 0.07 & $0.06--0.08$ & 0.0 & 7.7 & 5.3--7.2 & 1.4 & 53 & 34--72 & 27 \\
\hline M3 & 2 & 4.8 & 4.6--5.0 & 0.2 & 0.12 & $0.11--0.13$ & 0.0 & 4.1 & $1.1--1.8$ & 0.5 & 141 & $131--151$ & 14 \\
\hline \multicolumn{14}{|c|}{$\begin{array}{l}\text { ES: Transitional } \\
\text { Wetland }\end{array}$} \\
\hline $\mathrm{Oe}$ & 2 & 4.1 & $4.0--4.3$ & 0.2 & 0.22 & $0.21--0.23$ & 0.0 & 8.2 & 8.5--7.9 & 0.4 & 139 & 109--170 & 43 \\
\hline $\mathrm{Oa}$ & 3 & 3.8 & $3.6--4.0$ & 0.2 & 0.19 & $0.17--0.24$ & 0.0 & 8.8 & $4.1--16.9$ & 7.1 & 126 & 86--185 & 52 \\
\hline M1 & 4 & 3.8 & 3.7--3.8 & 0.0 & 0.10 & $0.07-0.12$ & 0.0 & 10.0 & $9.1--12.7$ & 1.8 & 165 & 68--253 & 78 \\
\hline M2 & 4 & 3.9 & $3.9--4.0$ & 0.1 & 0.06 & 0.05--0.09 & 0.0 & 9.2 & 6.3--10.4 & 1.9 & 220 & 69--415 & 144 \\
\hline M3 & 4 & 4.2 & $4.1--4.3$ & 0.1 & 0.05 & $0.03--0.06$ & 0.0 & 5.8 & 4.9--6.5 & 0.7 & 598 & 416--1082 & 323 \\
\hline M4 & 4 & 4.6 & $4.4--4.8$ & 0.2 & 0.03 & $0.01--0.05$ & 0.0 & 3.4 & $2.1--4.2$ & 0.9 & 480 & $354--549$ & 142 \\
\hline \multicolumn{14}{|c|}{ ES: Fen-Marsh } \\
\hline Oi & 3 & 4.5 & $3.9--4.9$ & 0.6 & 0.15 & $0.07--0.31$ & 0.1 & 9.0 & 6.3--13.0 & 3.56 & 440 & $95--855$ & 385 \\
\hline $\mathrm{Oe}$ & 4 & 4.8 & $3.9--5.7$ & 1.0 & 0.11 & $0.05--0.17$ & 0.0 & 7.4 & $0.1--19.7$ & 8.87 & 337 & 63--630 & 303 \\
\hline $\mathrm{Oa}$ & 4 & 4.7 & 3.8--5.9 & 1.0 & 0.12 & $0.10--0.14$ & 0.0 & 9.9 & $0.1--18.2$ & 8.90 & 74 & 48--96 & 20 \\
\hline M1 & 2 & 4.3 & $3.9--4.7$ & 0.5 & 0.07 & $0.06--0.07$ & 0.0 & 5.3 & 4.7--6.0 & 0.92 & 71 & 29--113 & 59 \\
\hline M2 & 1 & 4.8 & -- & -- & 0.07 & -- & -- & 1.2 & -- & -- & 45 & -- & -- \\
\hline M3 & 1 & 4.8 & -- & -- & 0.06 & -- & -- & 2.8 & -- & -- & 58 & -- & -- \\
\hline
\end{tabular}

${ }^{*} \mathrm{n}$ - is the number of sampling locations that contained that layer type 
hydrology. A marsh is located in the center of this wetland and a fen is positioned out on the edge of the wetland. When looking at the $\mathrm{pH}$ of the individual sampling locations, I observed lower $\mathrm{pH}$ values in the fen section and higher $\mathrm{pH}$ values in the marsh section (Appendix C). By definition a fen has no significant inflows and outflows (Mitsch and Gosselink, 2000), which means that basic cations are not being replenished and the soil $\mathrm{pH}$ is lowered. A marsh does have significant inflows and outflows allowing for replenishment of cations.

The average $\mathrm{pH}$ of the organic layers $(\mathrm{Oe}=4.1$ and $\mathrm{Oa}=3.8)$ for the Transitional Wetland was the lowest in the study (Table 3). These low average $\mathrm{pH}$ values resulted from the drier conditions present in these soils, which allows for organic acid generation through rapid decomposition of organic matter, and also allows for leaching of cations. In the Alder Thicket the average $\mathrm{pH}$ of the organic layers was 5.4 for both the Oe and $\mathrm{Oa}$ layers (Table 3). The Alder Thicket soil is much wetter then soil in the Transitional Wetland, and as a result, decomposition rates are reduced and less acidity is generated.

Electrical Conductivity (Ec) - Average Ec values were relatively low for all wetland soils (Table 3). The average Ec values for any soil layer never exceeded $0.22 \mathrm{dS} \mathrm{m}^{-1}$. In the non-impacted wetlands average Ec values tended to be higher in the organic layers and decreased in the mineral layers. In the AMD-impacted wetlands average Ec values were more variable with depth. The highest single Ec value observed in any organic horizon was $0.37 \mathrm{Ds} \mathrm{m}^{-1}$ in the Oi layer of stop 5 in Iron Pond (Appendix C). The higher value observed in this surface layer was probably related to the presence of pyritic material washed in from the surrounding mine spoils. 
Extractable Aluminum - Average extractable Al ranged from 0.0 to $11.9 \mathrm{cmol}_{\mathrm{C}} \mathrm{kg}^{-1}$ for all organic layers and 0.4 to $10.0 \mathrm{cmol}_{\mathrm{C}} \mathrm{kg}^{-1}$ for all mineral layers (Table 3). In general, average extractable $\mathrm{Al}$ was lowest in Narrow Wetland and was the highest in the Transitional Wetland, Fen-Marsh, and Railroad Grade. Values were observed to be as high as $22.1 \mathrm{cmol}_{\mathrm{C} \mathrm{kg}} \mathrm{kg}^{-1}$ in the non-impacted portion of Railroad Grade (Appendix C). Variability was high in this wetland as indicated by the high standard deviations and ranges (Table 3). Soils in the AMD-impacted section of Railroad Grade tended to have lower extractable $\mathrm{Al}$ than the non-impacted sections. In the Fen-Marsh, extractable Al was higher in the low $\mathrm{pH}$ fen portion of the wetland and lower in the marsh section. Since $\mathrm{Al}$ is more available at lower soil $\mathrm{pH}$ values, this explains why the low $\mathrm{pH}$ Transitional Wetland and the low $\mathrm{pH}$ fen contained the higher extractable $\mathrm{Al}$ values. Furthermore, the non-impacted sections of Railroad Grade had lower soil $\mathrm{pH}$ values and this may be why the extractable $\mathrm{Al}$ values were higher.

In Iron Pond, 0 to $2.3 \mathrm{cmol}_{\mathrm{C}} \mathrm{kg}^{-1}$ of $\mathrm{Al}$ was detected in the Oi layer of the first three sampling locations (Appendix C). At stops 4 and 5 extractable $\mathrm{Al}$ in the Oi layer increased to 10.9 and $5.6 \mathrm{cmol}_{\mathrm{C}} \mathrm{kg}^{-1}$, respectively. These values are similar to the 5.8 $\mathrm{cmol}_{\mathrm{C}} \mathrm{kg}^{-1}$ of Al that Wieder et al. (1988) reported for sphagnum peat receiving Al-rich water in a constructed wetland. Elevated Al concentrations are often found in AMD (Skousen et al., 2000), and Iron Pond is receiving AMD at multiple locations. Increased $\mathrm{Al}$ near the wetland terminus indicates that $\mathrm{Al}$ from the $\mathrm{AMD}$ is accumulating in the $\mathrm{Oi}$ layer. Wieder et al. (1988) fractionated the $\mathrm{Al}$ in their constructed wetland and they found that extractable Al constituted only $5.5 \%$ of the total Al. They reported that the organically bound form made up the largest portion (39.8 \%) of Al in the wetland. They 
also reported similar findings for a control section in this same wetland that was not receiving the Al-rich water. Their research indicates that the pool of Al sampled in my study only constitutes a small fraction of the total Al in the wetlands since $\mathrm{Al}$ is more likely to be present in states other then extractable form.

Total Iron -Average total Fe was highest in the Oi layer of Iron Pond (1588umol g and the Oi layer in Narrow Wetland (1504 $u \mathrm{~mol} \mathrm{~g}^{-1}$ ) (Table 3). The standard deviation in these layers indicates variability throughout these two wetlands, but variation became less with depth and much less variation was observed in the mineral layers than in the organic layers. In general, individual sampling locations in these two wetlands that appeared to be receiving more AMD had higher Fe concentrations. The values for the Oi layer in Iron Pond and Narrow Wetland where about 1.5 times greater than that observed by Wieder and Lang (1986) in the upper $20 \mathrm{~cm}$ of the AMD-impacted Tub Run Bog, and about three times greater than what we observed in the Oi layer of the Fen-Marsh wetland (Table 3). Wieder and Lang (1986) fractionated Fe in Tub Run Bog and found that $49 \%$ was in the organically bound form, and $50 \%$ was in the oxide form. Iron pools in Narrow Wetland are more likely to be similar to those reported by Wieder and Lang (1986), since little evidence of iron hydroxides was observed when the soils were sampled. In Iron Pond, reddish colors and precipitates indicated an abundance of Fe oxides at 4 of the 5 sampling locations indicating that much of the total iron may be in the oxide form. A separate study by Wieder et al. (1990) showed that 73 to $86 \%$ of the iron retained in a mesocosm wetland designed to treat synthetic AMD over 16 weeks was in the oxide form. They attributed this to rapid saturation of the organically bound 
exchange sites, leaving oxide formation as the primary means of iron retention. This process is most likely occurring in Iron Pond.

Average total $\mathrm{Fe}$ in the mineral layers of the AMD-impacted wetlands ranged from $66 u \mathrm{~mol} \mathrm{~g}^{-1}$ in the M4 layer of Narrow Wetland to $763 u \mathrm{~mol} \mathrm{~g}^{-1}$ in the M1 layer of Iron Pond (Table 3). The range of averages for the mineral layers in the non-impacted Elder Swamp wetlands was $33 u \mathrm{~mol} \mathrm{~g}^{-1}$ in the M1 layer of the Alder Thicket to $598 u \mathrm{~mol}$ $\mathrm{g}^{-1}$ in the M3 layer of the Transitional Wetland. Yet, in general, mineral layers in the AMD-impacted wetlands had higher Fe content than the non-impacted Elder Swamp wetlands, indicating some Fe from the AMD is accumulating in these subsurface layers (Table 3). Of all wetlands, Fen-Marsh mineral layers had the lowest average Fe content.

Total Carbon - In general, the average total C in the organic layers was lower in the AMD-impacted wetlands than in the non-impacted wetlands (Table 4). The lowest average value observed in any Oi layer (16.7 \%) was in Iron Pond, and the range for this layer was 9.6 to $26.0 \%$. In Narrow Wetland the average total C for the Oi layer was 24.1 $\%$, with a range of 16.5 to $28.9 \%$. The organic layers in Railroad Grade had higher average total $\mathrm{C}$ values that observed in the Oi layers of Iron Pond and Narrow Wetland $(\mathrm{Oi}=33.6 \%, \mathrm{Oe}=30.2 \%, \mathrm{Oa}=21.6)$, but the overall range for the organic layers was 14.8 to $41.5 \%$, with the low end values observed in the AMD-impacted portion of the wetland. The organic layers in the non-impacted areas of Railroad Grade had total C values similar to those observed in organic layers in Elder Swamp wetlands (Appendix C). Wieder and Lang (1986) reported much lower organic matter content in the upper 20 cm of Tub Run Fen, a wetland in West Virginia also impacted by AMD from Upper Freeport Coal spoils, than the non-impacted wetlands they included in their study. They 
attributed this to the transport of inorganic soil particles from the adjacent mine spoils, which would dilute the soil organic matter content. I believe that this process is lowering the C content in Iron Pond, Narrow Wetland, and the impacted portion of Railroad Grade. Furthermore, in Iron Pond and Narrow Wetland the abundance of Fe in the surface layers is also reducing the total carbon content.

Table 4. Average total carbon and total nitrogen for the organic horizons in wetland soils of the Beaver Creek Watershed, WV.

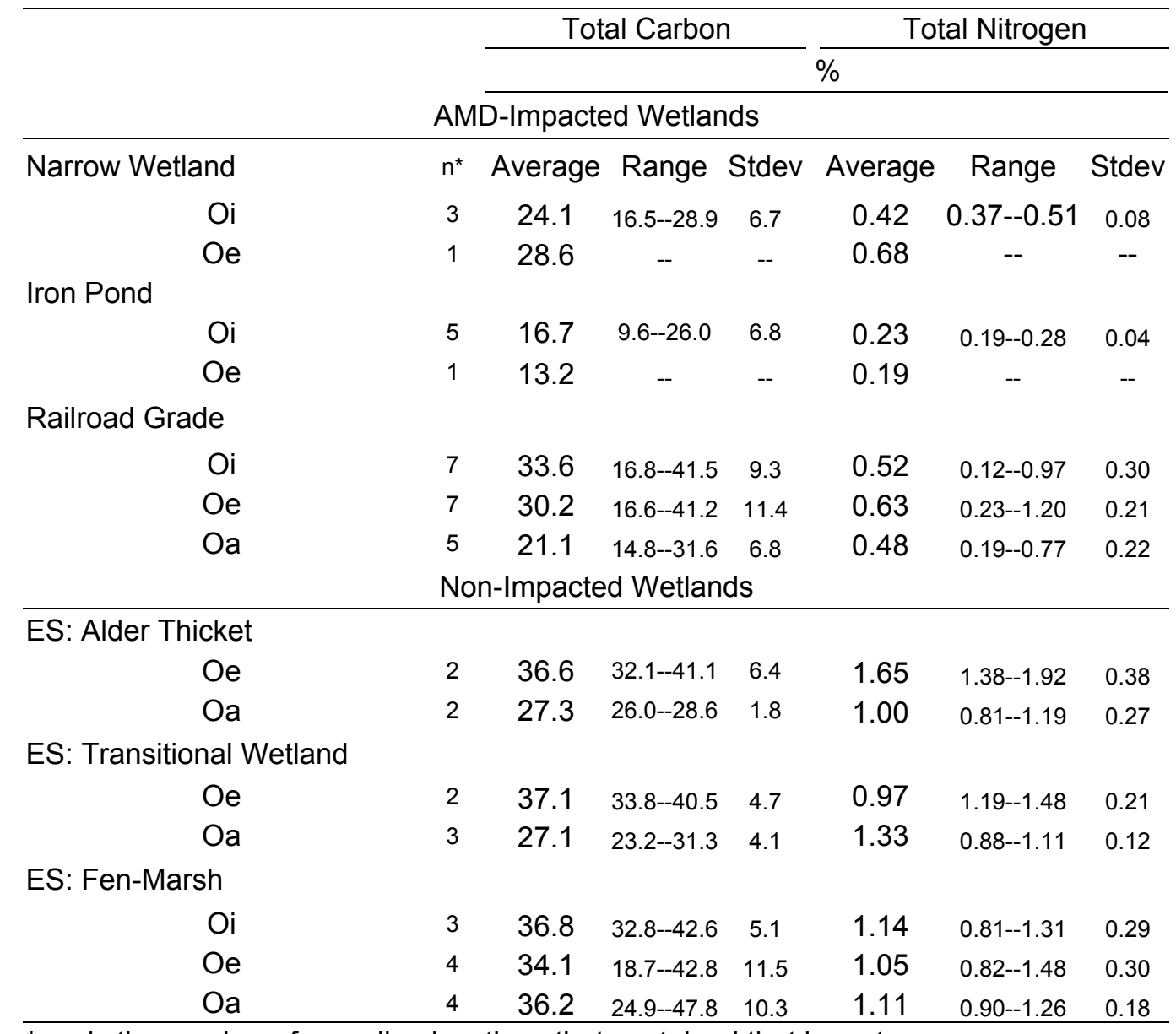

${ }^{*} \mathrm{n}$ - is the number of sampling locations that contained that layer type

The average $\mathrm{C}$ content of the organic layers in the Elder Swamp soils was generally greater than $35 \%$ (Table 4). In the Alder Thicket I observed average C content to be similar to values reported by Chambers (1996) for a wetland dominated by Alder in Canaan Valley, WV, an area just south of Beaver Creek. Average C content of the Fen- 
Marsh organic layers also was similar to values reported by Chambers (1996) for a mosslichen wetland in Canaan Valley. The Transitional Wetland also had C content similar to the Fen-Marsh and the Alder Thicket in the organic layers, but these layers were very thin $(<9 \mathrm{~cm})$. In contrast, the Fen-Marsh organic layers extend to depths greater than a 100 $\mathrm{cm}$ in some areas.

Average total $\mathrm{C}$ in the mineral layers was lowest in the Transitional Wetland and Iron Pond (Figure 4). In the remaining wetlands, average total $\mathrm{C}$ in any mineral layer was never lower than $4.8 \%$, indicating $\mathrm{C}$ is accumulating in the mineral layers of these wetlands (Figure 4). The lower carbon content of the Transitional Wetland mineral layers is related to the drier conditions, which favor $\mathrm{C}$ decomposition and reduced $\mathrm{C}$ accumulation. In Iron Pond though, the soils are saturated most of the year, but the $\mathrm{C}$ content in the mineral layers is still relatively low. The lower $\mathrm{C}$ content has resulted from the young age of this wetland soil. This wetland has developed since the construction of Rt 93, roughly 25 years ago. There has not been enough time for $\mathrm{C}$ to be incorporated into the mineral layers of this wetland.

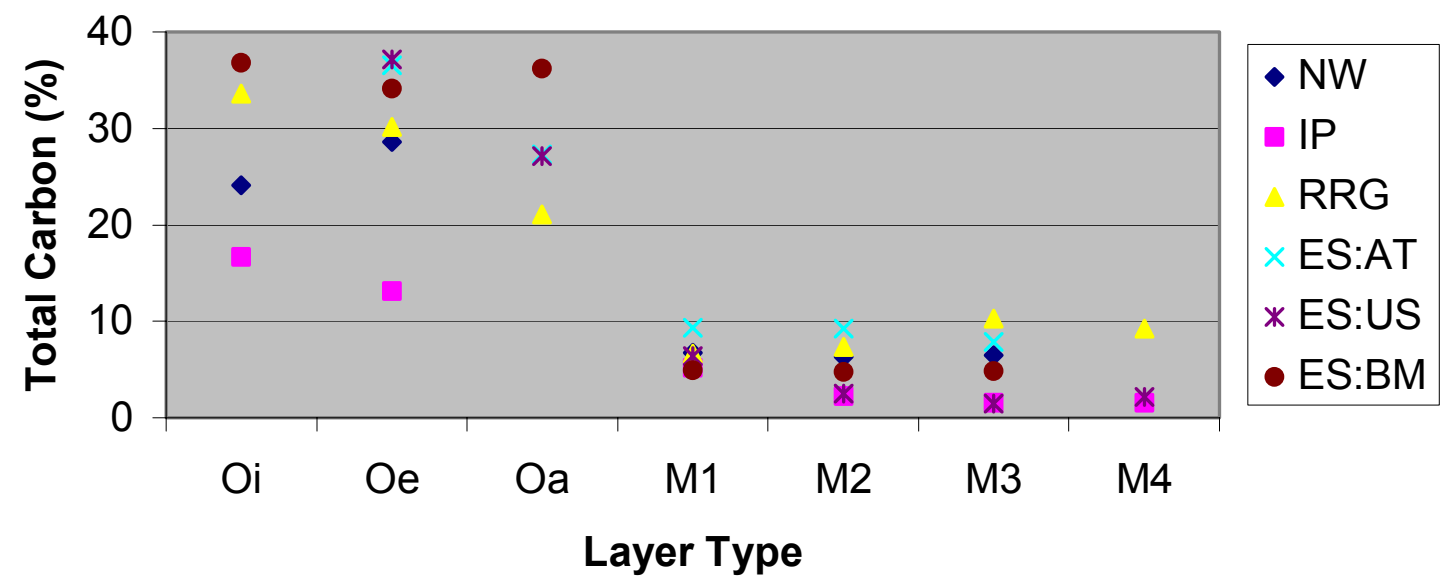

Figure 4. Average total carbon for all organic and mineral layers in wetlands of the Beaver Creek Watershed, WV. NW=Narrow Wetland, IP=Iron Pond, RRG=Railroad Grade, ES:AT=Elder Swamp: Alder Thicket, ES:TW=Elder Swamp: Transitional Wetland, and ES:BM=Elder Swamp: Fen-Marsh. 
Total Nitrogen - The highest average total $\mathrm{N}$ values $(>1.0 \%)$ for the organic layers were observed in the Elder Swamp soils (Table 4). The Oe horizon of the Alder Thicket had an average $\mathrm{N}$ content of $1.65 \%$, the highest in the study. This is similar to the $1.3 \%$ reported by Chambers (1996) for a wetland dominated by Alder in Canaan Valley. Alder is a $\mathrm{N}$ fixing plant, therefore high $\mathrm{N}$ values would be expected in wetlands dominated by this species.

The AMD-impacted wetlands contained much less $\mathrm{N}$ in the organic layers with the average values never exceeding $0.68 \%$ (Table 4). In Narrow Wetland and Iron Pond the ranges were small and the standard deviations moderate for the organic layers (Table 4). In Railroad Grade a wide overall range of 0.12 to $1.20 \%$ total $\mathrm{N}$ was observed for all of the organic layers (Table 4). The wide range resulted from the AMD-impacted sections containing much lower $\mathrm{N}$ than the non-impacted sections (Appendix $\mathrm{C}$ ). The lower $\mathrm{N}$ values observed in the AMD-impacted wetlands may be related to the same factors that lower the total $\mathrm{C}$ content. Translocation of inorganic particles, increased $\mathrm{Fe}$ content, and poor productivity will lower the total nitrogen content.

Cation Exchange Capacity (CEC) - Cation exchange capacity tended to be higher in the non-impacted wetlands. The highest average CEC value observed in this study was 67.0 $\mathrm{cmol}_{\mathrm{C}} \mathrm{kg}^{-1}$ in the Oa horizon of Fen-Marsh wetland (Figure 5). The range for this horizon was 47 to $88 \mathrm{cmol}_{\mathrm{C}} \mathrm{kg}^{-1}$ with the high end occurring in the marsh portion. The CEC values in the marsh are similar to what Johnson et al. (1995) reported for the Oa horizon of a Borosaprist in Minnesota. The lowest average CEC value $\left(23.1 \mathrm{cmol}_{\mathrm{C}} \mathrm{kg}^{-1}\right)$ 
in any organic horizon was observed in the Oe layer of the AMD-impacted Iron Pond (Figure 5).

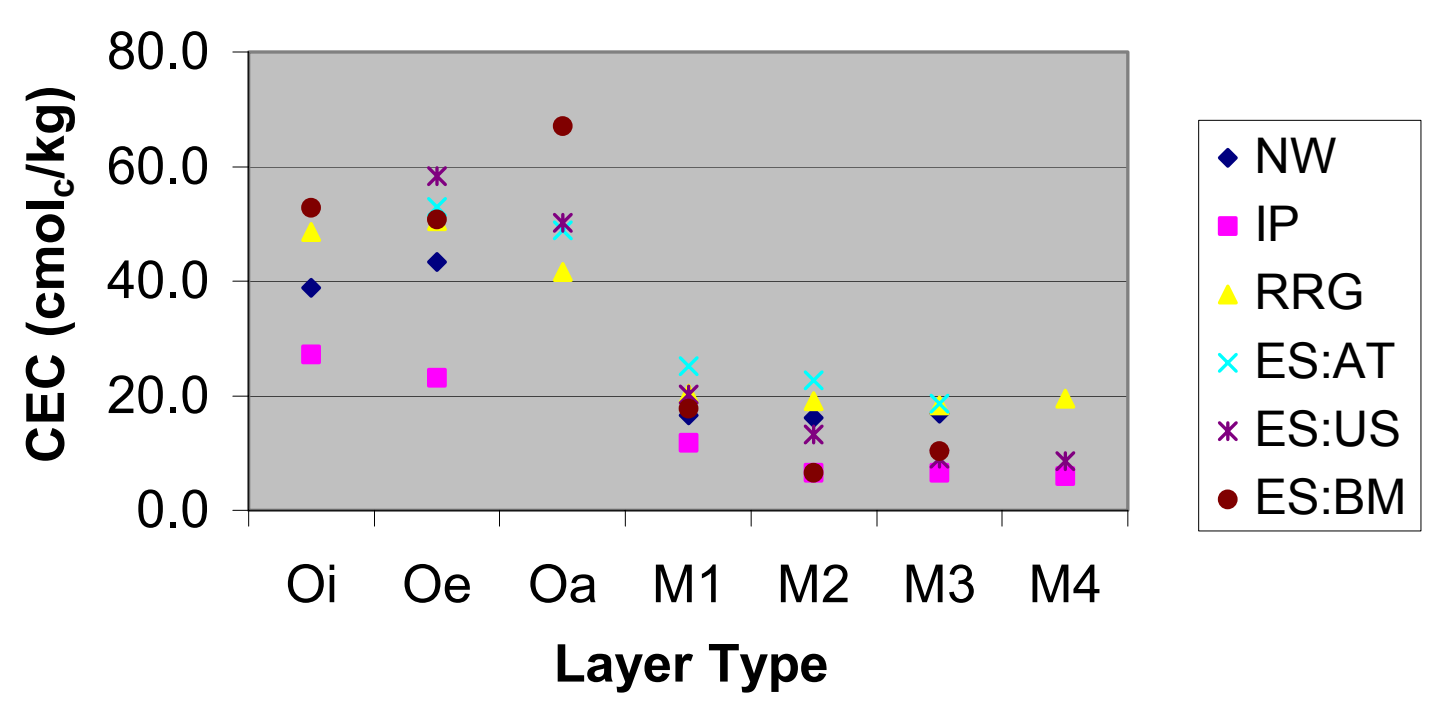

Figure 5. Average cation exchange capacity (CEC) for all organic and mineral layers in wetlands of the Beaver Creek Watershed, WV. NW=Narrow Wetland, IP=Iron Pond, RRG=Railroad Grade, ES:AT=Elder Swamp: Alder Thicket, ES:TW=Elder Swamp: Transitional Wetland, and ES:BM=Elder Swamp: Fen-Marsh.

The organic layers in the AMD-impacted wetlands tended to have lower average CECs than the non-impacted Elder Swamp soils (Figure 5). There is a strong relationship between total carbon and CEC (Figure 6) and it is believed that the low CEC values in the AMD-impacted wetlands are related to the lower carbon content. Wieder et al (1988) also reported significantly lower CEC for impacted peat samples verses non-impacted peat samples.

The CEC dropped sharply in the mineral layers of all soils (Figure 5). By definition mineral layers have less carbon therefore this trend reflects the strong relationship between CEC and total carbon in soils. 
Exchangeable Bases - In all organic and mineral layers, for all wetlands, Ca was the most abundant exchangeable base and $\mathrm{Mg}$ was the second most abundant exchangeable

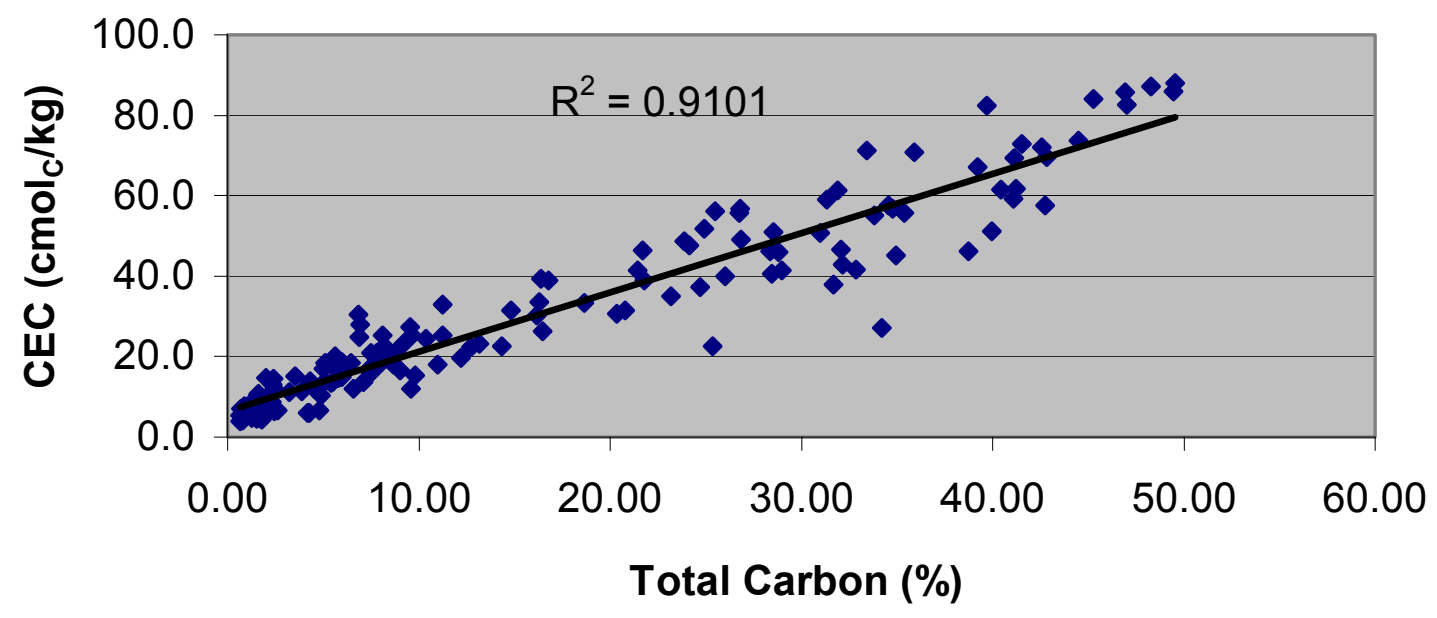

Figure 6. Relationship between total carbon and cation exchange capacity (CEC) for all organic horizons and mineral layers in wetland soils of the Beaver Creek Watershed. WV.

base (Table 5). Less exchangeable $\mathrm{Na}$ and $\mathrm{K}$ were detected than $\mathrm{Ca}$ and $\mathrm{Mg}$ in all wetlands (Table 5). Studies by Wieder et al. (1987) and Wieder (1990) reported similar results for sphagnum peat and sawdust substrates.

In the organic layers the average total exchangeable bases were highest in the Alder Thicket, but the ranges for these layers overlap with the ranges for the organic layers in all the AMD-impacted wetlands. The lowest total exchangeable bases for the organic layers were observed in the Transitional Wetland followed by the Fen-Marsh wetland (Table 5). The low exchangeable base content would be expected for the low $\mathrm{pH}$ Transitional Wetland, because the lower $\mathrm{pH}$ soils have lower CEC. As for the Fen-Marsh wetland, the low average exchangeable base content is a result of the low $\mathrm{pH}$ fen section of this wetland. The high $\mathrm{pH}$ marsh portion of the wetland had values similar to those observed in the Alder Thicket (Appendix C). 
Table 5. Exchangeable calcium (Ca), magnesium (Mg), sodium ( $\mathrm{Na}$ ), and potassium (K) using the pH 7 buffered ammonium acetate method for wetland soils In the Beaver Creek Watershed, WV. Organic horizon sampled by type, mineral horizons sample by depth with $\mathrm{M} 1$ being the uppermost layer and $\mathrm{M} 4$ being the lowest layer.

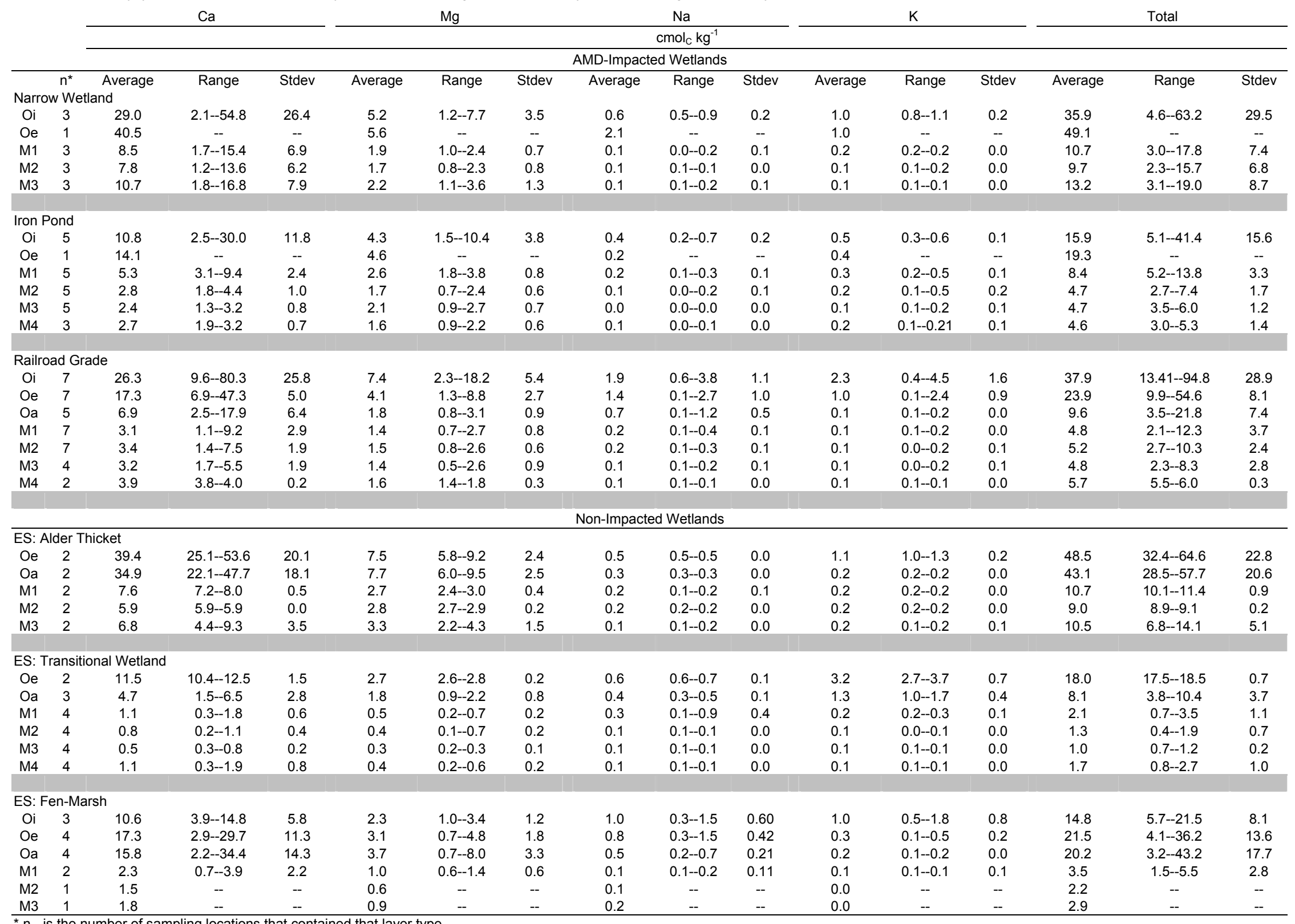

${ }^{*} \mathrm{n}$ - is the number of sampling locations that contained that layer type 
Looking at the AMD-impacted wetlands I observed that the Oi horizon in Iron Pond showed the following decrease in total exchangeable base content when moving from the head of the wetland to the terminus: 41.1, 20.3, 5.6, 7.1, 5.1 $\mathrm{cmol}_{\mathrm{C}} \mathrm{kg}^{-1}$. This trend is related to a decrease in soil $\mathrm{pH}$ and an increase in Fe content. Wieder (1990) studied metal cation binding to sphagnum peat by loading the peat with 10 different cations. He reported that $\mathrm{Fe}$ was adsorbed preferentially over $\mathrm{Ca}, \mathrm{Mg}, \mathrm{Na}$, and $\mathrm{K}$. Furthermore, he reported that cations such as $\mathrm{Ca}$ and $\mathrm{Mg}$ were such poor competitors for exchange sites that there was net desorption during the loading sequence. In a separate study that was conducted to observe $\mathrm{Ca}$, and $\mathrm{Mg}$ dynamics in a mesocosm wetland subjected to AMD, Wieder et al. (1990) reported that the sphagnum peat become a net source for $\mathrm{Ca}$ and $\mathrm{Mg}$. This was attributed to Fe and $\mathrm{Al}$ being preferentially adsorbed to exchange sites over $\mathrm{Ca}$ and $\mathrm{Mg}$. These studies indicate that in AMD-impacted wetlands, where $\mathrm{Fe}$ is abundant, important cations will be released.

Sulfur Fractions - Average total S was highest in the Oe layer of Narrow Wetland $\left(849.4 u \mathrm{~mol} \mathrm{~g}^{-1}\right)$ and lowest in the M2 layer of the Transitional Wetland $\left(10.7 u \mathrm{~mol} \mathrm{~g}^{-1}\right)$ (Table 6). When comparing the Oi layers in all wetlands I observed that average total S was generally higher in the AMD-impacted wetlands as compared to the Fen-Marsh in Elder Swamp. Average total S values for all AMD-impacted Oi layers were much higher than the $108 u \mathrm{~mol} \mathrm{~g}^{-1}$ Wieder and Lang (1986) reported for Tub Run Bog, and were similar to those reported by Griffin and Rabenhorst (1989) for the surface layer of a tidal marsh soil. Tidal marsh soils receive sulfate-rich seawater, so these data indicate that the surface Oi layers of the wetlands are receiving and retaining additional $\mathrm{S}$ from the inflowing AMD. 
Table 6. Average total sulfur (S), sulfate $\left(\mathrm{SO}_{4}\right)$, acid volatile sulfides (AVS), chromium reducible sulfides (CRS), and organic sulfur for wetland soils in the Beaver Creek Watershed, WV. Organic horizons sampled by type, mineral layers sampled by depth with M1 being the uppermost layer and M4 being the lowest layer.

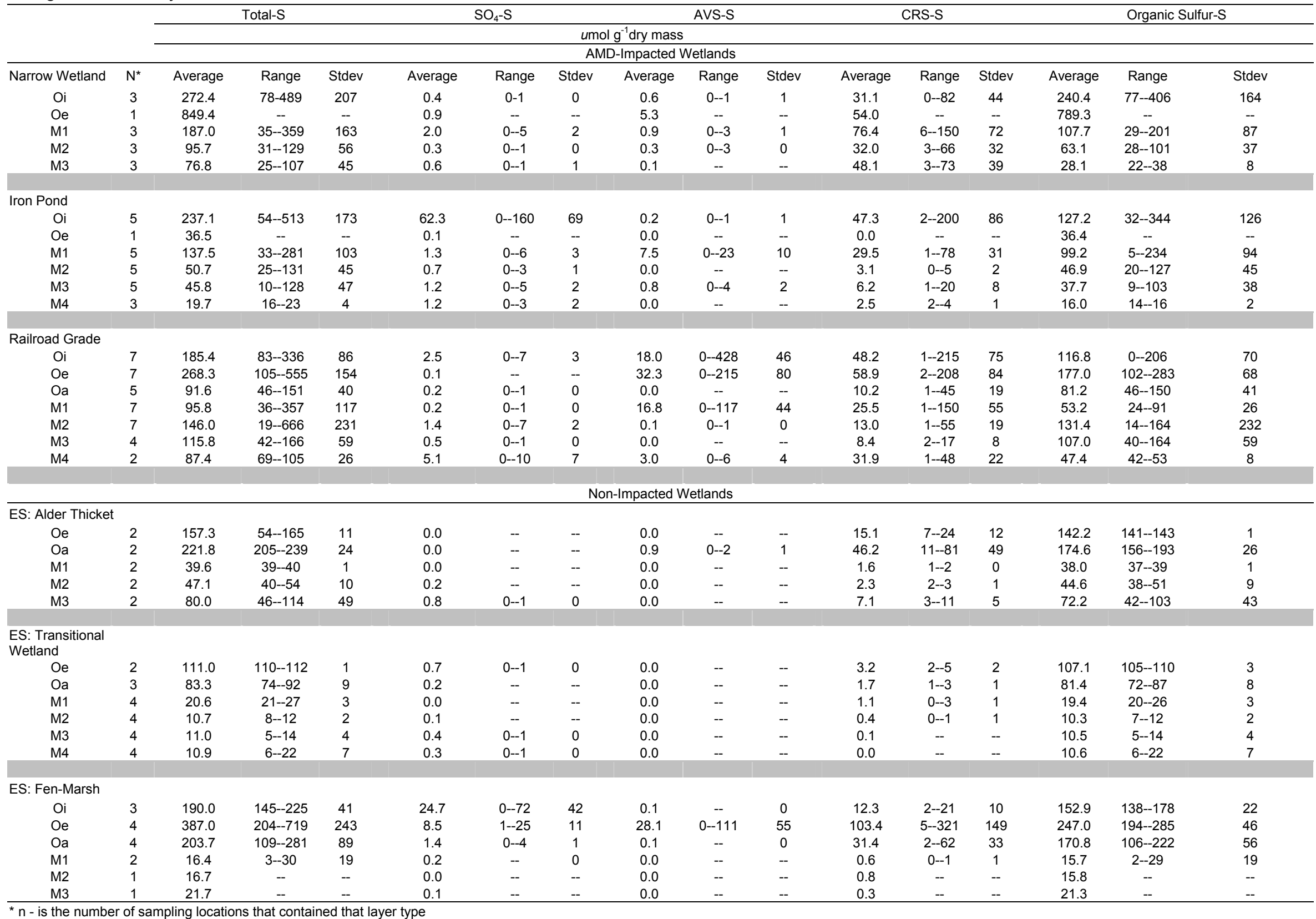

${ }^{*} \mathrm{n}$ - is the number of sampling locations that contained that layer type 
Sulfur was generally higher in the mineral layers of the AMD-impacted wetlands as compared to the non-impacted wetlands (Table 6). The M1 layers in all three of the AMDimpacted wetlands had average total S values similar to those reported by Wieder and Lang (1986) for the organic surface layer in Tub Run Bog. This indicates that additional sulfur from the AMD is entering these layers and being retained.

Average $\mathrm{SO}_{4}{ }_{4}^{2-}$ was highest in the Oi layer of Iron Pond $\left(62.3 u \mathrm{~mol} \mathrm{~g}^{-1}\right)$, and $\mathrm{SO}_{4}{ }^{2-}$ constituted $26.3 \%$ of the total S pool in this layer (Tables 6 and 7). The Oi layer in the FenMarsh had the next highest $\mathrm{SO}_{4}{ }^{2-}$ concentration $\left(24.7 u \mathrm{~mol} \mathrm{~g}^{-1}\right)$, and it constituted $13.0 \%$ of the total S pool (Tables 6 and 7). In Tub Run Bog, Wieder and Lang (1986) observed that only $5.4 \%$ of the $\mathrm{S}$ was in the $\mathrm{SO}_{4}^{2-}$ form. Laudon's (1989) data for a constructed wetland designed to treat $\mathrm{AMD}$ showed that 2.9 to $25 \%$ of the total $\mathrm{S}$ was in the $\mathrm{SO}_{4}{ }^{2-}$ form. These data indicate that $\mathrm{SO}_{4}{ }^{2-}$ from the $\mathrm{AMD}$ is being retained in Iron Pond, and $\mathrm{SO}_{4}{ }^{2-}$ from the nearby coal refuse pile is being retained in the Fen-Marsh wetland. Little $\mathrm{SO}_{4}{ }^{2-}$ entering Iron Pond is being reduced to AVS, and not all $\mathrm{SO}_{4}$ in the Fen-Marsh wetland is being reduced.

The Oi layer in Iron Pond is saturated with iron hydroxides, and almost no AVS was detected in this layer. Since AVS indicates S reduction, the abundance of iron hydroxides along with the lack of AVS indicates that $\mathrm{S}$ reduction is not occurring in this layer. $\mathrm{For} \mathrm{SO}_{4}{ }^{2-}$ to be reduced, the Fe, in the ferric form, must first be reduced to ferrous Fe. Therefore the abundance of iron hydroxides indicates that Fe has not been completely reduced and $\mathrm{S}$ reduction cannot readily occur.

The highest average AVS value was found in the Oe layer of Railroad Grade (32.3 $u$ mol g $\left.{ }^{-1}\right)$, and the next highest average AVS value was in the Oe layer of Fen-Marsh (28.1 $u$ mol g${ }^{-1}$ ) (Table 6). The AMD-impacted portion of Railroad Grade had the highest average 
Table 7. Average percentage of total sulfur that each form of sulfur constitutes in wetland soils in the Beaver Creek Watershed, WV. Organic horizons sampled by type, mineral layers sampled by depth with M1 being the uppermost layer and M4 being the lowest layer.

\begin{tabular}{|c|c|c|c|c|c|}
\hline & & SO4-S & AVS & CRS & Organic-S \\
\hline & & \multicolumn{4}{|c|}{$\%$ of total S } \\
\hline \multicolumn{6}{|c|}{ AMD-Impacted Wetlands } \\
\hline Narrow Wetland & $\mathrm{n}^{*}$ & & & & \\
\hline Oi & 3 & 0.1 & 0.2 & 11.4 & 88.2 \\
\hline $\mathrm{Oe}$ & 1 & 0.1 & 0.6 & 6.4 & 92.9 \\
\hline M1 & 3 & 1.1 & 0.5 & 40.9 & 57.6 \\
\hline M2 & 3 & 0.3 & 0.3 & 33.4 & 66.0 \\
\hline M3 & 3 & 0.8 & 0.1 & 62.6 & 36.5 \\
\hline \multicolumn{6}{|l|}{ Iron Pond } \\
\hline Oi & 5 & 26.3 & 0.1 & 20.0 & 53.7 \\
\hline $\mathrm{Oe}$ & 1 & 0.3 & 0.0 & 0.0 & 99.7 \\
\hline M1 & 5 & 0.9 & 5.4 & 21.5 & 72.1 \\
\hline M2 & 5 & 1.3 & 0.1 & 6.0 & 92.6 \\
\hline M3 & 5 & 2.6 & 1.8 & 13.5 & 82.2 \\
\hline M4 & 3 & 5.8 & 0.2 & 12.7 & 81.2 \\
\hline \multicolumn{6}{|l|}{ Railroad Grade } \\
\hline $\mathrm{Oi}$ & 7 & 1.3 & 9.7 & 26.0 & 63.0 \\
\hline $\mathrm{Oe}$ & 7 & 0.0 & 12.1 & 22.0 & 66.0 \\
\hline $\mathrm{Oa}$ & 5 & 0.3 & 0.0 & 11.1 & 88.6 \\
\hline M1 & 7 & 0.2 & 17.6 & 26.6 & 55.6 \\
\hline M2 & 7 & 1.0 & 0.1 & 8.9 & 90.0 \\
\hline M3 & 4 & 0.4 & 0.0 & 7.2 & 92.4 \\
\hline M4 & 2 & 5.9 & 3.5 & 36.5 & 54.2 \\
\hline \multicolumn{6}{|c|}{ Non-Impacted Wetlands } \\
\hline \multicolumn{6}{|c|}{ ES: Alder Thicket } \\
\hline Oe & 2 & 0.0 & 0.0 & 9.6 & 90.4 \\
\hline $\mathrm{Oa}$ & 2 & 0.0 & 0.4 & 20.8 & 78.7 \\
\hline M1 & 2 & 0.0 & 0.0 & 4.0 & 96.0 \\
\hline M2 & 2 & 0.4 & 0.0 & 4.8 & 94.8 \\
\hline M3 & 2 & 0.9 & 0.0 & 8.9 & 90.2 \\
\hline \multicolumn{6}{|l|}{$\begin{array}{l}\text { ES: Transitional } \\
\text { Wetland }\end{array}$} \\
\hline Oe & 2 & 0.6 & 0.0 & 2.9 & 96.5 \\
\hline $\mathrm{Oa}$ & 3 & 0.2 & 0.0 & 2.1 & 97.7 \\
\hline M1 & 4 & 0.1 & 0.0 & 5.5 & 94.4 \\
\hline M2 & 4 & 0.9 & 0.0 & 3.5 & 95.6 \\
\hline M3 & 4 & 3.9 & 0.0 & 1.2 & 95.0 \\
\hline M4 & 4 & 3.2 & 0.0 & 0.1 & 96.7 \\
\hline \multicolumn{6}{|l|}{ ES: Fen-Marsh } \\
\hline $\mathrm{Oi}$ & 3 & 13.0 & 0.0 & 6.5 & 80.5 \\
\hline $\mathrm{Oe}$ & 4 & 2.2 & 7.3 & 26.7 & 63.8 \\
\hline $\mathrm{Oa}$ & 4 & 0.7 & 0.1 & 15.4 & 83.8 \\
\hline M1 & 2 & 1.1 & 0.0 & 3.5 & 95.4 \\
\hline M2 & 1 & 0.3 & 0.0 & 4.9 & 94.8 \\
\hline M3 & 1 & 0.5 & 0.0 & 1.4 & 98.1 \\
\hline
\end{tabular}

\footnotetext{
${ }^{*} \mathrm{n}-$ is the number of wetland sites that contained that layer type
} 
AVS in the Oi, Oe, and M1 layers of any wetland (Appendix C). No AVS was detected in the non-impacted section of this wetland (Appendix C). The highest AVS value observed at any one individual sampling location in any wetland was $428 u \mathrm{~mol} \mathrm{~g}^{-1}$ in the Oi layer of an AMDimpacted sampling location in Railroad Grade (Appendix C). This is about 4 times greater then any value Laudon (1989) reported and 138 times greater than the $3.1 u \mathrm{~mol} \mathrm{~g}^{-1}$ that Wieder and Lang (1986) reported for Tub Run Bog surface layer. These data, along with the lack of $\mathrm{SO}_{4}{ }^{2-}$, indicate that $\mathrm{S}$ reduction is occurring in the AMD-impacted surface organic layers of Railroad Grade. In Narrow Wetland the Oe layer had $5.3 u \mathrm{~mol} \mathrm{~g}^{-1} \mathrm{AVS}$, which is similar to values reported by Wieder and Lang (1986). The lower average value for AVS indicates that little $\mathrm{S}$ has been recently reduced in Narrow Wetland.

No AVS was detected in the Transitional Wetland and very little was observed in the Alder Thicket (Table 6). Except for the M1 layers in all AMD-impacted wetlands, very little AVS was detected in any of the mineral layers. The M1 layers in all AMD-impacted wetlands had an average AVS of 0.9 to $16.8 u \mathrm{~mol} \mathrm{~g}^{-1}$. This indicates that some $\mathrm{S}$ was being reduced and retained in the first mineral layer (Appendix C).

The Transitional Wetland and the Alder Thicket had the lowest amount of CRS detected (Table 6). The highest CRS value observed was in the Oe layer of the Fen-Marsh wetland $\left(103.4 u \mathrm{~mol} \mathrm{~g}^{-1}\right)$ and this value was similar to the $131.0 u \mathrm{~mol} \mathrm{~g}^{-1} \mathrm{CRS}$ reported by Laudon (1989). At least $2.5 \mathrm{umol} \mathrm{g}{ }^{-1} \mathrm{CRS}$ was detected in all AMD-impacted wetland mineral and organic layers, indicating that at least some $\mathrm{S}$ reduction has occurred in all of the AMDimpacted wetlands (Table 6). In the Fen-Marsh wetland, less than $1.0 u \mathrm{~mol} \mathrm{~g}^{-1} \mathrm{CRS}$ was observed in any mineral layer. This is related to the lack of Fe in these layers, which is required to form iron sulfides. The values for average CRS in the organic layers of the AMD- 
impacted wetlands (except for the Oe layer in Iron Pond) were much higher than the $15.1 \mathrm{umol}$ $\mathrm{g}^{-1}$ that Wieder and Lang (1986) reported for Tub Run Bog. Yet, our total S values were higher than the values reported for Tub Run Bog and the percentage of the total S that our CRS constituted was similar to the $14 \%$ they reported (Table 7)

Wieder and Lang (1986) reported that $75 \%$ of the $\mathrm{S}$ in the surface layer of AMDimpacted Tub Run Bog was in the organic form and 85 to $88 \%$ of the sulfur in their three nonimpacted wetlands was in the organic form. Table 7 shows that for all organic layers in the Alder Thicket and the Transitional Wetland, 78.7 to $97.7 \%$ of the sulfur was in the organic form. If I include the Fen-Marsh with the AMD-impacted wetlands, I observed that for all organic layers of the AMD-impacted wetlands 53.7 to $99.7 \%$ of the sulfur was in the organic form. The AMD-impacted wetlands tended to have more sulfur in the form of CRS. In Railroad Grade and Iron Pond the sulfur was likely to be in the AVS and/or $\mathrm{SO}_{4}{ }^{2-}$ forms.

Redox Potential - Redox Potential was measured at depths of 10 and $20 \mathrm{~cm}$. This approach was used to observe near surface redox characteristics in some wetlands and to relate the Eh to $\mathrm{Fe}$ and $\mathrm{SO}_{4}$ reduction in the surface of the AMD-impacted wetlands. A soil is considered reduced when all the oxygen has been removed and the $\mathrm{NO}_{3}{ }^{-}$begins to be reduced to $\mathrm{NH}_{4}{ }^{+}$. It is generally accepted that this occurs at an Eh of 200 to $250 \mathrm{mV}$ (Ponnamperuma, 1972; Mitsch and Gosselink, 2000). The Eh at $10 \mathrm{~cm}$ in Iron Pond shows that reducing conditions were present almost the entire year at stops 2 and 4 , but that at stop 5, the soil was reduced only from July to November (Figure 7). The redox electrodes at stop 5 were placed in a hummock of sphagnum moss, which was situated above the water table, thus allowing oxidizing conditions for part of the year. 


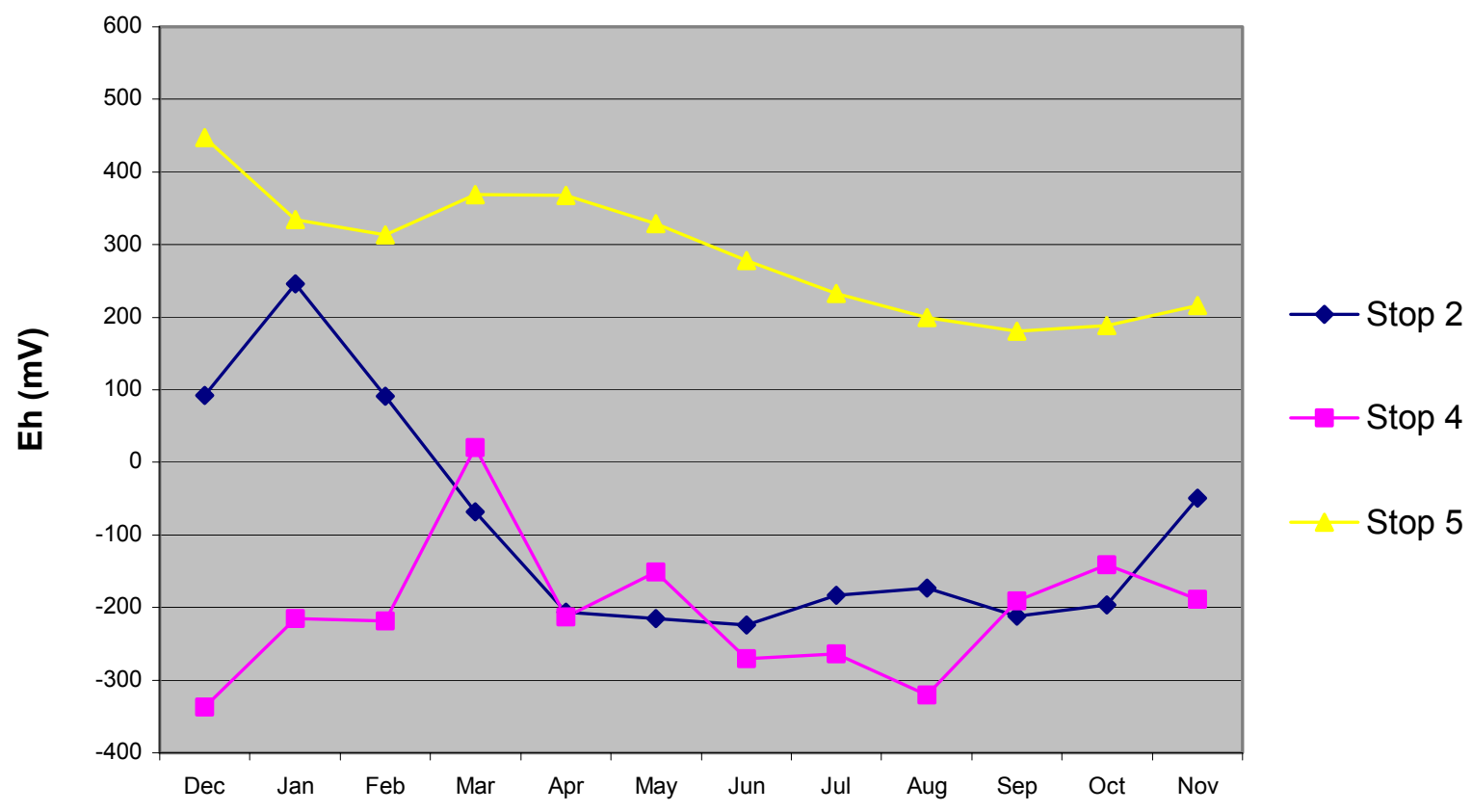

Month

Figure 7. Redox Potential (Eh) at $10 \mathrm{~cm}$ adjusted to represent $\mathrm{pH} 7$ in three sampling locations in Iron Pond wetland of the Beaver Creek Watershed, WV.

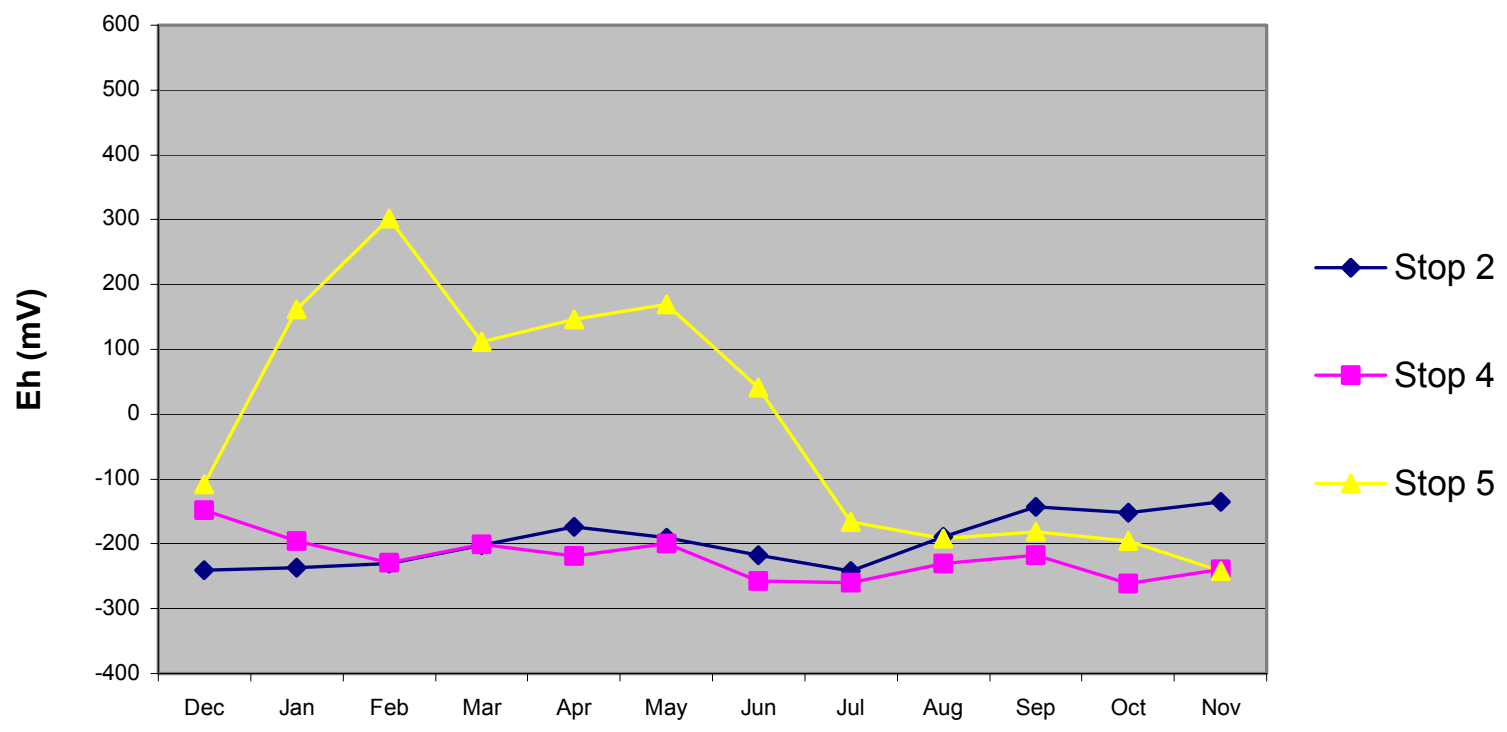

Month

Figure 8. Redox Potential (Eh) at $20 \mathrm{~cm}$ adjusted to represent $\mathrm{pH} 7$ in three sampling locations in Iron Pond wetland of the Beaver Creek Watershed, WV. 
Patrick and Jugsujinda (1992) studied the sequential reduction of $\mathrm{NO}_{3}{ }^{-}, \mathrm{Fe}^{3+}$, and $\mathrm{SO}_{4}{ }^{2-}$ in a flooded silt loam amended with rice straw at $\mathrm{pH}$ 6.5. They reported that ferrous iron appeared in solution only when $\mathrm{NO}_{3}{ }^{-}$had been reduced and Fe reduction began around 100 $\mathrm{mV}$. They also reported $\mathrm{SO}_{4}$ reduction occurred at -100 to $-200 \mathrm{mV}$. At $10 \mathrm{~cm}$ in Iron Pond (Figure 7), stops 2 and 4 had an Eh that was low enough for $\mathrm{Fe}$ and $\mathrm{SO}_{4}{ }^{2-}$ reduction to occur during the warmer spring and summer months. In the winter, the higher redox potential was assumed to be due to a decline in microbial activity. The $10 \mathrm{~cm}$ probes were situated in the Oi layer and in this layer average values for AVS were low $\left(0.2 u \mathrm{~mol} \mathrm{~g}^{-1}\right)$ and average values for $\mathrm{SO}_{4}{ }^{2-}$ were high $\left(62.3 \mathrm{umol} \mathrm{g}^{-1}\right)$. These data indicate that despite low Eh, little $\mathrm{SO}_{4}{ }^{2-}$ from the AMD is being reduced. Average values for CRS were $47.3 u \mathrm{~mol} \mathrm{~g}^{-1}$, but this probably resulted from pyritic material washing in form the surrounding mine spoils. Iron hydroxides were observed in the Oi layer, indicating that not all Fe is being reduced. This may be limiting the $\mathrm{SO}_{4}{ }^{2-}$ reduction process. Before $\mathrm{SO}_{4}{ }^{2-}$ is reduced most of the Fe must be reduced.

At $20 \mathrm{~cm}$ in Iron Pond, stops 2 and 4 are consistently reduced around $-200 \mathrm{mV}$ (Figure 8). Stop 5 had a fluctuating Eh but was still reduced most of the year (Figure 8). These data indicate that conditions are present in stops 2 and 4 that would favor $\mathrm{Fe}$ and $\mathrm{SO}_{4}$ reduction at the 20-cm depth in Iron Pond. The M1 layer at stops 2 and 4 begins at 23 and $21 \mathrm{~cm}$, respectively, so redox values at $20 \mathrm{~cm}$ may reflect conditions in these layers. High total $\mathrm{S}$ content was observed in the Oi and M1 layers at these two stops. Little AVS were detected in the Oi layer, but $7.5 \mathrm{umol} \mathrm{g}{ }^{-1}$ AVS were detected in the M1 layer indicating $\mathrm{SO}_{4}$ reduction was occurring. 
In Railroad Grade, the redox electrodes were located on a transect that started at the AMD-impacted stop 1 and went slightly upslope towards non-impacted stops 2 and 3. The Eh data at both 10 and $20 \mathrm{~cm}$ reflected differences in hydrology along the transect, with the wetter stop 1 having a lower Eh at both 10 and $20 \mathrm{~cm}$ than the drier stops 2 and 3 (Figures 9 and 10). This is similar to a trend reported by Faulkner et al. (1989) for a transect that spanned from a wetland site to a non-wetland site.

Throughout the year in Railroad Grade, Eh at both 10 and $20 \mathrm{~cm}$, at stop 1, was low enough for $\mathrm{Fe}$ and $\mathrm{SO}_{4}{ }^{2-}$ to be reduced. Very high levels of $\mathrm{S}$ in the form of AVS and CRS were detected at stop 1 and no $\mathrm{SO}_{4}{ }^{2-}$ was detected at 10 or $20 \mathrm{~cm}$ at this sampling location. Carbon is a necessary energy source for microbial reduction of S (Ponnamperuma, 1972), and $\mathrm{C}$ levels were above $6.6 \%$ at these two depths. The low Eh, in conjunction with the $\mathrm{C}$ content, high AVS, and low $\mathrm{SO}_{4}{ }^{2-}$ indicate that $\mathrm{SO}_{4}{ }^{2-}$ entering the soil from the AMD is readily being reduced at this sampling location.

In Railroad Grade, stop 2 had reducing conditions present all year long at both 10 and $20 \mathrm{~cm}$, and stop 3 was reduced at $20 \mathrm{~cm}$ most of the year (Figures 9 and 10). At $10 \mathrm{~cm}$, stop 3 was subjected to periods of reduction during the wetter spring months and was oxidized the remainder of the year (Figure 9). Both stops 2 and 3 were not receiving AMD, and so $\mathrm{SO}_{4}$ reduction was not of much concern at these two sampling locations.

The Eh graphs for Elder Swamp show a variable Eh for the soil in the scrub-shrub wetland at both 10 and $20 \mathrm{~cm}$ (Figures 11 and 12). The Eh is lower at $10 \mathrm{~cm}$ than at $20 \mathrm{~cm}$ during most of the sampling period. At the 10-cm depth the probes are in a high-carbon A horizon and at $20 \mathrm{~cm}$ the probes are situated in a low-carbon B horizon. Carbon in the A horizon is providing an energy source to microorganisms, which 


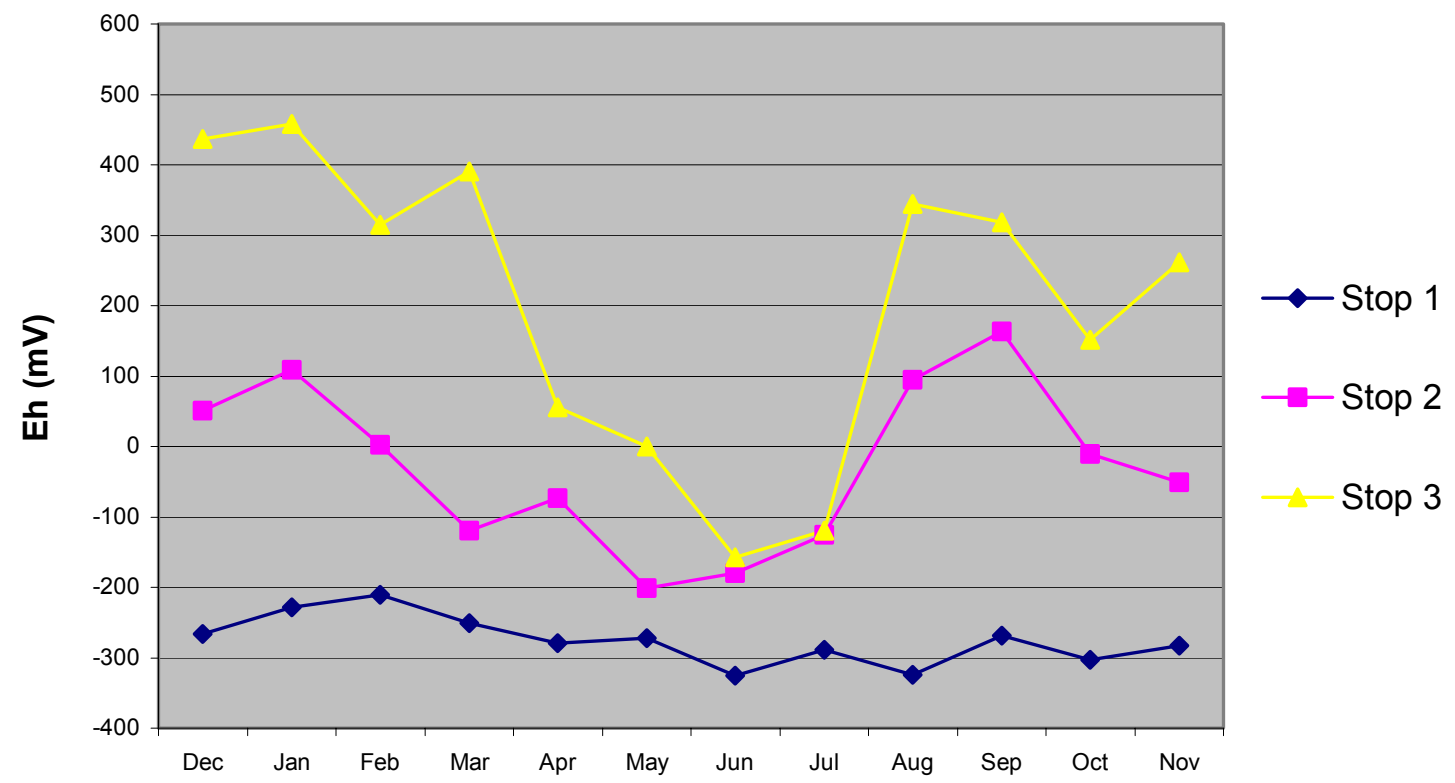

Month

Figure 9. Redox Potential (Eh) at $10 \mathrm{~cm}$ adjusted to represent $\mathrm{pH} 7$ in three sampling locations in Railroad Grade wetland of the Beaver Creek Watershed, WV.

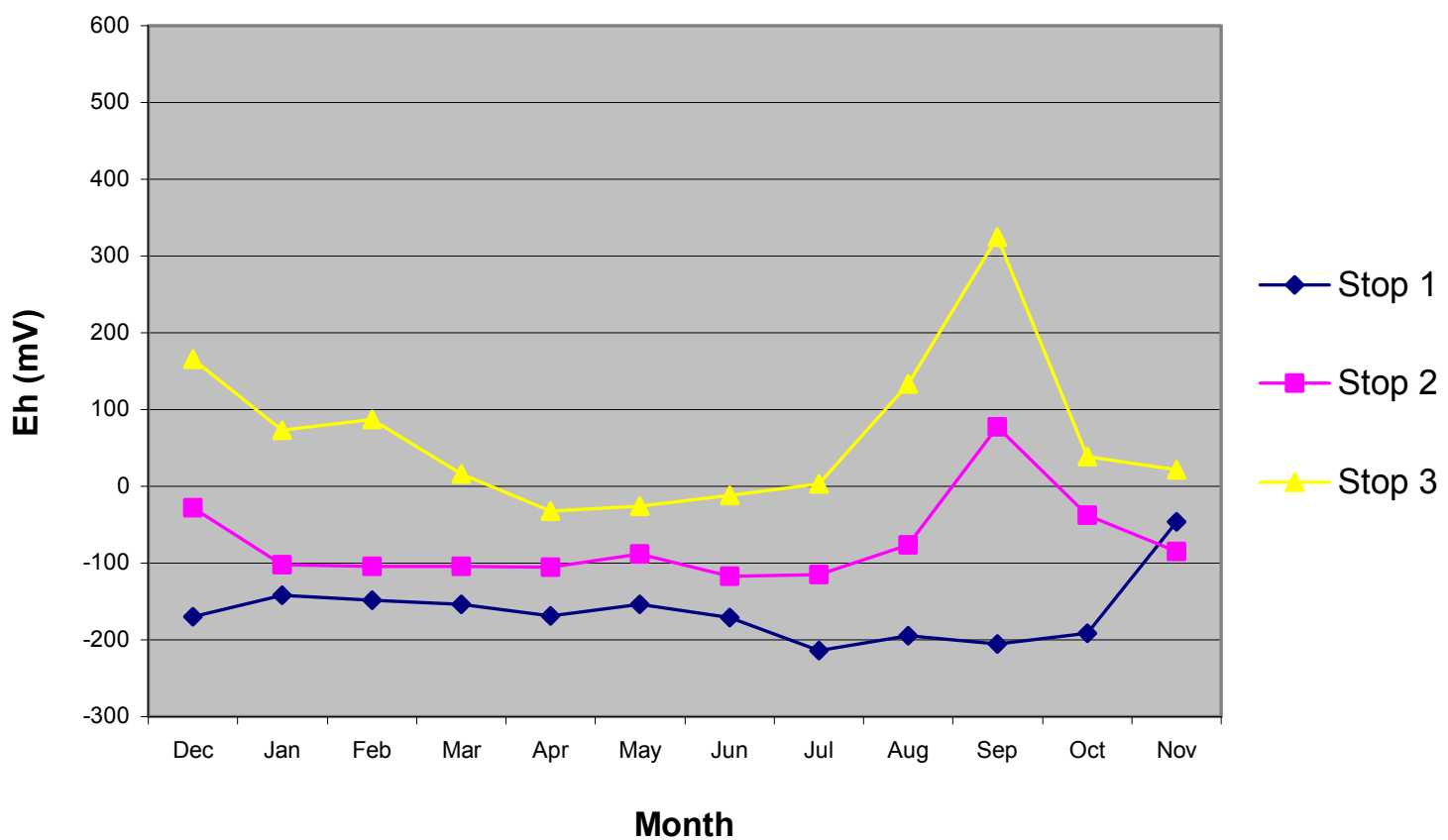

Figure 10. Redox Potential (Eh) at $20 \mathrm{~cm}$ adjusted to represent $\mathrm{pH} 7$ in three sampling locations in Railroad Grade wetland of the Beaver Creek Watershed, WV. 


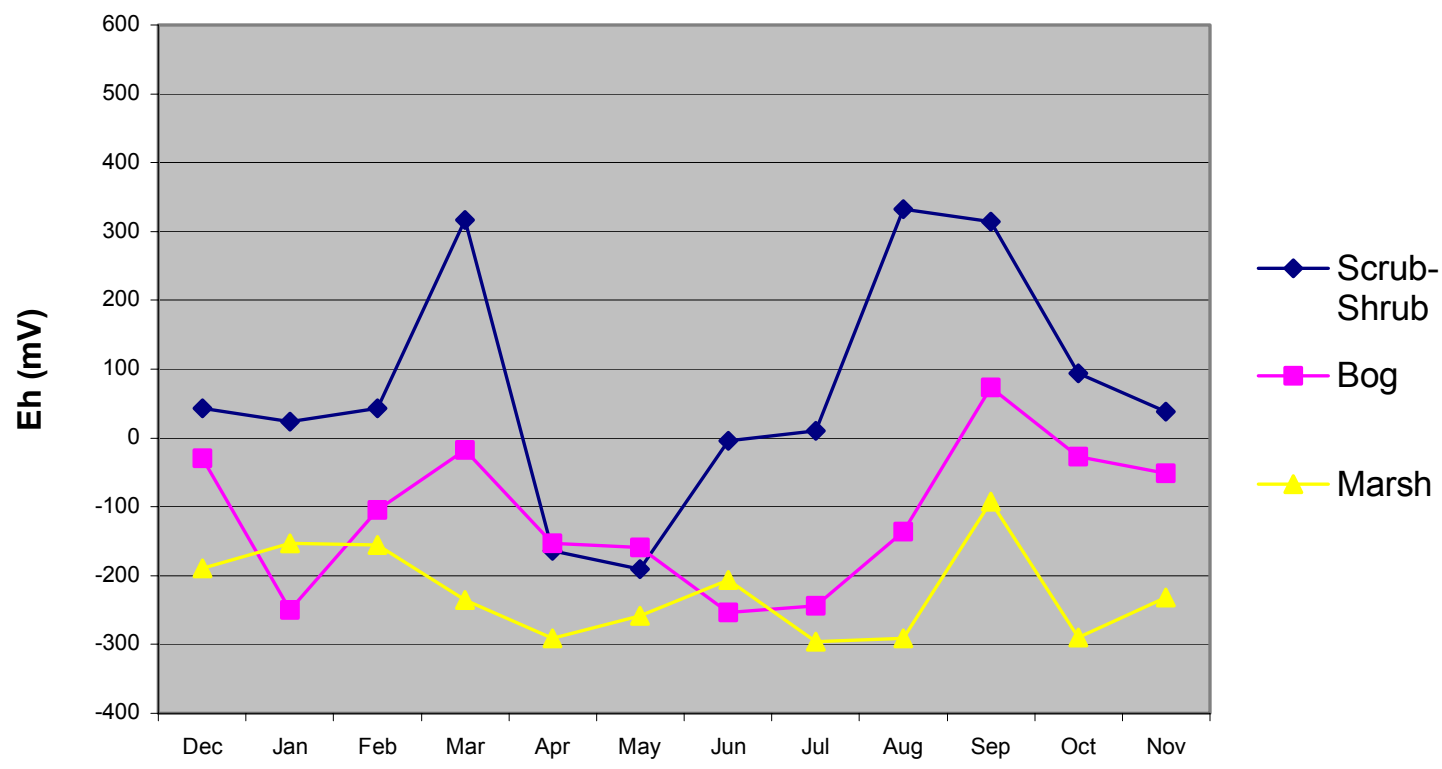

Month

Figure 11. Redox Potential (Eh) at $10 \mathrm{~cm}$ adjusted to represent $\mathrm{pH} 7$ in three sampling locations in Elder Swamp of the Beaver Creek Watershed, WV.

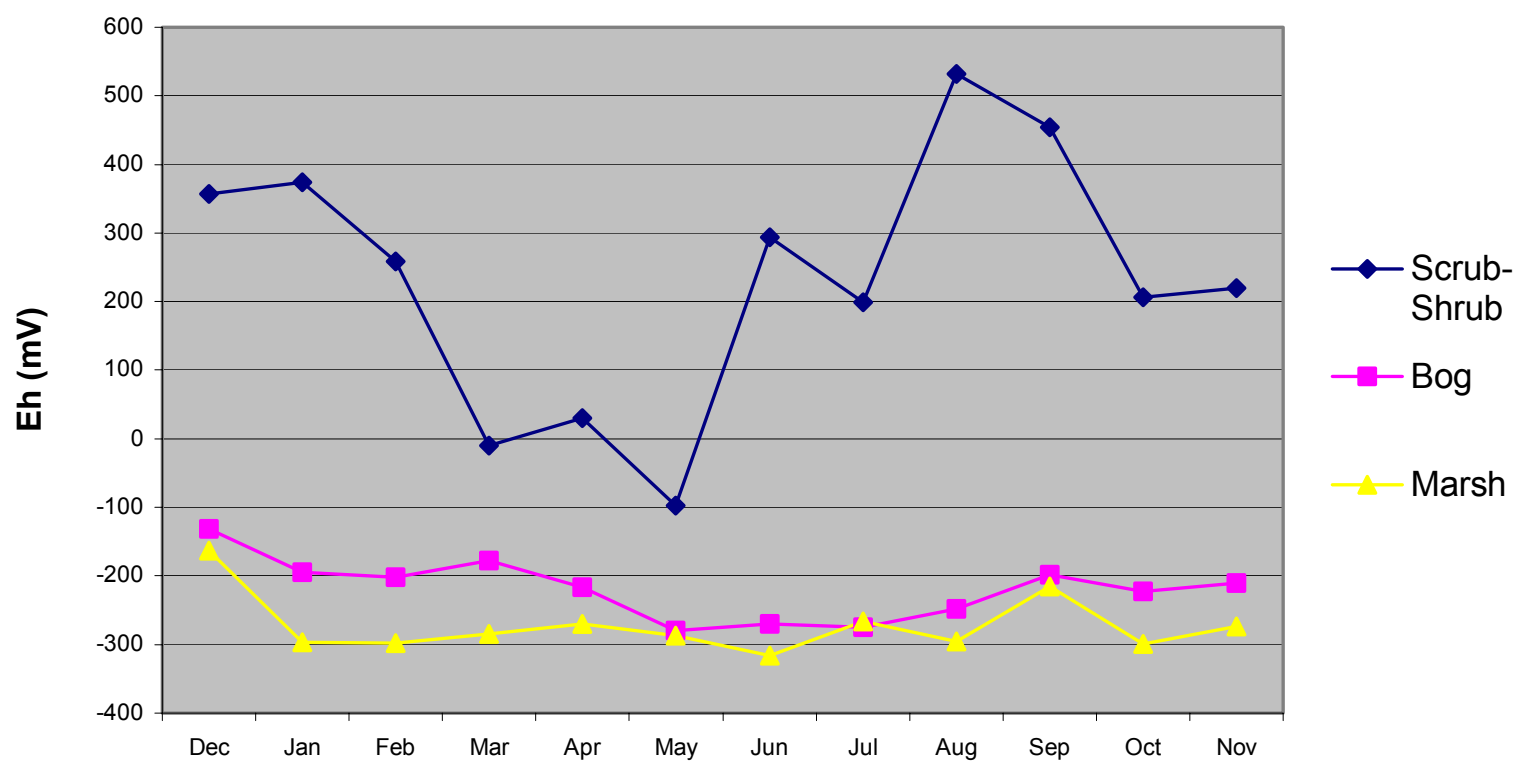

Month

Figure 12. Redox Potential (Eh) at $20 \mathrm{~cm}$ adjusted to represent $\mathrm{pH} 7 \mathrm{in}$ three sampling locations in Elder Swamp of the Beaver Creek Watershed, WV. 
increases the reduction rate. Less $\mathrm{C}$ is available in the $\mathrm{B}$ horizon, therefore the reduction process was inhibited. The Eh diagram for the scrub-shrub wetland indicates a transitional area where the water table fluctuates rapidly near the surface. The diagram has a degree of variability similar to that reported by Faulkner et al. (1989) for their transitional wetland, where the water table was shown to fluctuate at a depth of $30 \mathrm{~cm}$.

In the fen and the marsh, at $20 \mathrm{~cm}$, the Eh was consistently below $-100 \mathrm{mV}$ throughout the year, indicating that $\mathrm{Fe}$ should be reduced (Figure 12). The fen and the marsh had conditions that favor $\mathrm{SO}_{4}$ reduction at this depth. At $10 \mathrm{~cm}$, the fen and marsh soils showed somewhat more fluctuation than at $20 \mathrm{~cm}$, but the Eh was never above $100 \mathrm{mV}$ (Figure 11). The fen and marsh soils are organic soils so reducing conditions that favor organic matter accumulation were expected to prevail throughout most of the year. 


\section{SUMMARY AND CONCLUSIONS}

Soils have developed under different conditions in the study area along Beaver Creek. As a result, some wetlands in this study displayed a wide range of soil characteristics. In Elder Swamp, the Fen-Marsh wetland consisted of Histosols formed by years of organic matter accumulation under reduced conditions. Redox potential data confirm the presence of yearround strong reducing conditions, which favor organic matter accumulation. Upslope from the Fen-Marsh wetland was the drier Transitional Wetland, which had low total carbon values. These soils were subjected to a fluctuating water table, which had resulted in mottles, thin organic layers, and variable redox conditions. The water table in these soils was being perched by the presence of a fragipan. Soils in the Alder Thicket were much wetter then in the Transitional Wetland but still not as saturated as the Fen-Marsh soils. However, organic material was accumulating in this wetland as evidenced by the high carbon content of the mineral layers and 20-cm thick organic layer.

All other wetlands were impacted by mining activities. In Narrow Wetland mine spoils are situated along the western boundary. As a result sediments and AMD were impacting this wetland by increasing iron and sulfur content and diluting carbon content. Additionally, hydrology in Narrow Wetland was altered by the construction of Rt. 93, which created saturated conditions. Prior to the construction of Rt. 93 Narrow Wetland was subjected to drier conditions. Route 93 was impeding drainage from Narrow Wetland and as a result organic matter was beginning to accumulate. Iron Pond had formed as a result of past mining activities. This wetland was essentially a sediment trap that has filled in with material that had washed in from surrounding mine spoils. Soil in this wetland consisted of undeveloped fill 
material in the subsurface with thick, low pH, Oi horizons present at the surface. Iron Pond was receiving AMD form multiple locations and this wetland was by far the most severely AMD-impacted wetland in the study. Despite these impacts a diverse vegetative community was present. Railroad Grade wetland was only partially impacted by mining activities in the eastern portion. In the impacted section, sediments and AMD had washed in from adjacent mine spoils. The impacted area was characterized by the presence of buried organic layers and little vegetative growth. The buried organic layers indicated that sediments washing in from the adjacent mine spoils buried the original soil. The unimpacted section contained Histic epipedons but no Histosols were present.

Wetlands impacted by AMD tended to have lower $\mathrm{C}$ and $\mathrm{N}$ concentrations in the organic layers than the non-impacted wetlands. These findings were similar to those Wieder and Lang (1986) reported for the AMD-impacted Tub Run Bog. They attributed the reduced organic matter content to translocation of inorganic particles from the nearby mine spoils, and the increased iron content to the inflowing AMD. I believe that these same processes were occurring in the AMD-impacted wetlands. Of the non-impacted soils, Fen-Marsh organic layers contained the highest $\mathrm{C}$ content and the Alder Thicket soils had the most N. Since Alder is a $\mathrm{N}$-fixing species high $\mathrm{N}$ values were expected in this wetland.

Soil pH, Ec, extractable Al, particle size, and exchangeable bases had high standard deviations and little differences were observed between the non-impacted and AMD-impacted soils. Differences were observed in total Fe, CEC, and forms of S. Non-impacted wetlands tended to have higher $\mathrm{CEC}$, less $\mathrm{Fe}$, less total $\mathrm{S}$, and less $\mathrm{S}$ in the form $\mathrm{AVS}$ or $\mathrm{SO}_{4}{ }^{2-}$. Most AMD-impacted wetlands were retaining Fe and S from the AMD and as result concentrations of these elements were greater in these wetlands. 
Redox potential in the AMD-impacted Iron Pond and Railroad Grade is low enough to indicate that $\mathrm{Fe}$ and $\mathrm{SO}_{4}{ }^{2-}$ from the inflowing AMD could be reduced. In Railroad Grade the organic layers had high values for total $\mathrm{S}, \mathrm{AVS}$, and CRS along with low $\mathrm{SO}_{4}{ }^{2-}$ values, which indicates that $\mathrm{S}$ is being reduced in this wetland. In Iron Pond almost no AVS was detected in the Oi layer and $\mathrm{SO}_{4}{ }^{2-}$ constituted $26.3 \%$ of the total S pool in the Oi layer. This was attributed to the abundance of oxidized ferric iron, which must first be reduced before $\mathrm{SO}_{4}$ could be reduced, and the poor quality of organic material as an energy source for microbial reduction of S. Sulfate reduction does not appear to be readily occurring in Iron Pond.

Sulfate in drainage from a nearby coal refuse pile appeared to be entering the soils in the Fen-Marsh wetland. Data indicate that most of this $\mathrm{SO}_{4}{ }^{2-}$ in this wetland was being retained and reduced in the marsh portion of the wetland. This was because the marsh was the area of the wetland that received the majority of the drainage. The redox potential for the marsh area indicates that conditions that favor sulfate reduction at both 10 and $20 \mathrm{~cm}$ are present. The organic materials in these wetlands are in a well-decomposed form and this also increases the sulfate reduction process.

In general the AMD-impacted wetlands tended to have more total S, AVS, CRS, and $\mathrm{SO}_{4}{ }^{2-}$ than the non-impacted wetlands. In non-impacted wetlands sulfur was more likely to be in the organic form, and almost no sulfur was in the AVS form. Of the organic layers in all non-impacted wetlands, $\mathrm{SO}_{4}{ }^{2-}$ or AVS were found to constitute more than $0.6 \%$ of the total $\mathrm{S}$ pool in only the Oi and Oe layers of the Fen-Marsh. This is because the Fen-Marsh was receiving $\mathrm{SO}_{4}{ }^{2-}$ sulfur from the nearby coal refuse pile.

Results from this study indicate that wetlands could be constructed to serve as passive treatment systems in the treatment of AMD following the Construction of Appalachian 
Corridor H. To effectively treat AMD, constructed wetlands should contain $40-50 \mathrm{~cm}$ of a high quality organic matter substrate, such as spent mushroom compost, underlined with 10-20 cm limestone. Based upon the results in this study and results reported by Wieder (1993) sphagnum peat should be avoided as an organic substrate in constructed wetlands. Wieder's (1993) results and my observations of the Oi layer of Iron Pond indicate that sphagnum peat will retain $\mathrm{Fe}$ and acidity, but little $\mathrm{SO}_{4}{ }^{2-}$ will be reduced.

Cattails should be planted to stabilize the substrate, decrease channelization through promotion of sheet flow (Stark et al., 1995), and provide additional organic matter to the soil over time. Limestone will generate alkalinity through dissolution of calcium carbonate and the organic matter will have two main functions: provide an energy source for the microbial reduction of metals and $\mathrm{SO}_{4}{ }^{2-}$ and provide exchange sites for the binding of metals precipitated from AMD. The water table should be maintained near the surface to ensure reducing conditions. Also, alkalinity will be generated through the $\mathrm{S}$ reduction process.

Much research has been conducted on the efficiency of constructed wetlands to treat AMD (Wieder 1993; Stark et al., 1994; Tarutis and Unz, 1996). Results of these studies showed that wetlands were effectively treating AMD through retention of metals, hydrogen protons, and $\mathrm{SO}_{4}{ }^{2-}$. Research has shown that wetlands are more efficient in treating AMD when the drainage was mild (Stark et al., 1995). If the AMD has a low $\mathrm{pH}(<3)$, and high $\mathrm{Fe}$ $(>100 \mathrm{mg} / \mathrm{L}$ ), treatment efficiency of constructed wetlands has been shown to be finite (Wieder, 1993). Eventually the exchange sites in the wetland soil became saturated with metal, and alkalinity generation is inhibited. To increase treatment efficiency, the wetlands should be used as part of a larger treatment system that is designed to increase alkalinity and remove the metals from the AMD before it enters the wetland. Settling ponds, designed to 
retain iron and other metals, should be placed prior to the treatment wetlands. The main function of the wetlands would than be to remove $\mathrm{SO}_{4}{ }^{2-}$, generate alkalinity, and serve as a back up system for metal removal when the sediment ponds are overwhelmed during storm events.

During construction of Appalachian Corridor H, both Iron Pond and Narrow Wetland will be impacted and potentially destroyed. These wetlands are currently treating AMD and this function should be replaced. Railroad Grade is situated to the northwest and impacts from highway construction may not be as severe. If any impacts are going to occur to Railroad Grade, an attempt should be made to only impact the eastern portion of the wetland were AMD and sediments have already caused severe damage. Highway construction will not directly impact Elder Swamp. 


\section{Literature Cited}

Appalachian Regional Commission. 1969. Acid mine drainage in Appalachia. Congr. House Doc. 91-180. Vol. I-III. Appendix C. Appalachian Regional Commission, Washington, DC.

Callebaut, F., D. Gabriels, W. Minjauw, and M. De Boodt. 1982. Redox potential, oxygen diffusion rate, and soil gas composition in relation to water table in two soils. Soil Sci. 134:149-156.

Chambers, D.B..1996. Physical, chemical, and biological data for four wetland habitats in Canaan Valley West Virginia. U.S. Geological Survey. Open-File Report 95-334.

Chapman, S.J.. 2001. Sulphur forms in open and afforested areas of two Scottish Peatlands. Water Air Soil Pollut. 128:23-39.

Cowardin, L.M., V. Carter, F.C. Golet, and E.T. LaRoe. 1979. Classification of wetlands and deepwater habitats of the United States. U.S. Fish and Wildl. Serv. FWS/OBS-79/31. U.S. Gov. Print Office, Washington DC.

Diamond, D. 2001. Determination of sulfide by flow injection analysis. Lachat Instruments. QuikChem method 10-116-29-1-C.

Egan, L. 1998. Determination of sulfate by flow injection analysis. Zellweger Analytics INC. QuickChem method 12-116-10-1-D.

Environmental Laboratory. 1987. Corps of Engineers wetlands delineation manual. Tech. Rep. Y-87-1. U.S. Gov. Army Engineer Experiment Station, Vicksburg, Miss.

Faulkner, S.P. and W.H. Patrick, Jr. 1992. Redox processes and diagnostic wetland indicators in bottomland hardwoods forests. Soil. Sci. Soc. Am. J. 56:856-865.

Faulkner, S.P., W.H. Patrick, and R.P. Gambrell. 1989. Field techniques for measuring wetland soil parameters. Soil Sci. Soc. of Am. J.. 53:883-890.

Feng, J, and Y.P. Hsieh. 1998. Sulfate reduction in freshwater wetland soil and the effects of sulfate and substrate loading. J. Environ. Qual. 27:968-972.

Fuhrmann., J.J. 1998. Microbial metabolism. Chapter 10. p.189-217. In D. M. Sylvia, J.J. Fuhrmann, P.G. Hartel, and D.A. Zuberer (ed.) Principles and Applications of Soil Microbiology. Prentice-Hall, Inc. Upper Saddle River, New Jersey. 
Gambrell, R. P., and W H. Patrick, Jr. 1978. Chemical and microbiological properties of anaerobic soils and sediments. P. 375-423. In D .D. Hook and R. M. M. Crawford (ed). Plant Life in Aerobic Environments. Ann Arbor Sci. Pub. Inc. Ann Arbor Mich.

Geidel, G.,and F.T. Caruccio. 2000. Geochemical factors affecting coal mine drainage quality. Chapter 5. p. 105-130. In R.I. Barnhisel, R.G. Darmody, and W.L. Daniels (ed.) Reclamation of Drastically Disturbed Lands. American Society of Agronomy, Crop Science Society of Agronomy, Soil Science Society of Agronomy, Madison WI.

Griffin, T.M. and M.C. Rabenhorst.1989. Processes and rates of pedogenesis in some Maryland tidal marsh soils. Soil Sci. Soc. Am. J. 53:862-870.

Henrot, J., and R. K. Wieder. 1990. Processes of iron and manganese retention in laboratory peat microcosms subjected to acid mine drainage. J. Environ. Qual. 19:312-320.

Hou, A.X., G.X. Chen, Z.P. Wang, O. Van Cleemput, and W.H. PatricK, Jr. 2000. Methane and nitrous oxide emissions from a rice field in relation to soil redox and microbiological processes. Soil Sci. Soc. Am. J. 64:2180-2186.

Howeler, R .H., and D. R. Bouldin. 1971. The diffusion and consumption of oxygen in submerged soils. Soil Sci. Soc. Am. J. 35:202-208.

Johnson, C.A., G. Pinay, C. Arens, and R.J. M Naiman. 1995. Influence of soil properties on the biogeochemistry of a beaver meadow hydrosequence. Soil Sci. Soc. Am. J. 59:1789-1799

Kaplan, I.R., K.O. Emery, and S.C. Ritterberg. 1973. The distribution and isotopic abundance of sulfur in recent marine sediments off southern California. Geochimica et Cosmochimica Acta. 27:297-331.

Kararthanasis, A.D., Y.L. Thompson, and C.D. Barton. 2003. Long-term evaluations of seasonally saturated "wetlands" in western Kentucky. Soil Sci. Soc. Am. J. 67:662673.

Kennedy, L.G., J.W. Everett, K.J. Ware, R. Parsons, and V. Green. 1999. Iron and sulfur mineral analysis methods for natural attenuation assessments. Bioremediation J. 249: 133-154.

Laudon, L.S. 1989. Sulfur mineralization in a wetland constructed to treat acid mine drainage. Masters Thesis, Colorado School of Mines. Golden, Co.

Losche., C.K. and W. W. Beverage. 1967. Soil Survey of Tucker County and part of Northern Randolph County, West Virginia. USDA Soil Conservation Service. U.S. Gov. Printing Office. Washington, D.C. 
McLatchey., G. P., and K. R. Reddy. 1998. Regulation of organic matter decomposition and nutrient release in a wetland soil. 27:1268-1274.

Meek, B D., A. J. McKenzie, and L. B. Gross. 1968. Effects of organic matter, flooding time, and temperature on the dissolution of iron and manganese from the soil in situ. Soil. Sci. Soc. Am. J. 32:634-638.

Megonigal, J P., W. H. Patrick, and S. P. Faulkner. 1993. Wetland identification in seasonally flooded forest soils: soil morphology and redox dynamics. Soil Sci. Soc. Am. J. 57:140-149.

Mitsch W.J., and J.G. Gosselink. 2000. Wetlands. Third Addition. John Wiley \& Sons Inc. New York, NY.

Novak, M. and R.K. Wieder. 1992. Inorganic and organic sulfur in nine Sphagnum peat bogs in the United States and Czechoslovakia. Water Air Soil Pollut. 65:353-369.

Patrick, W.H., and A. Jugsujinda. 1992. Sequential reduction and oxidation of inorganic nitrogen, manganese, and iron in flooded soil. Soil Sci. Soc. Am. J. 56:1071-1073.

Pickering, E.W., and P.L.M. Veneman. 1984. Moisture regimes and morphological characteristics in a hydrosequence in central Massachusetts. Soil. Sci. Soc. Am. J. 48:113-118.

Ponnamperuma, F.N. 1972 The chemistry of submerged soils. Adv. Agron.. 24:29-96.

Reddy, K.R., and W.H. Patrick. 1975. Effects of alternate aerobic and anaerobic conditions on redox potential, organic matter decomposition, and nitrogen loss in a flooded soil. Soil Biol. Biochem. 7:87-94.

Richardson, J.L and M.M Brinson. 2001. Wetland soils and the hydrogeomorphic Classification of wetlands. Chapter 9. p. 209-228. In Richardson, J.L., and M.J. Vepraskas (ed.) Wetland soils: genesis, hydrology, landscapes and classification Lewis Publishers, Boca Raton, Florida.

Sarrantonio, M., J.W. Doran, M.A. Liebeg, and J.J. Halvorson. 1996. On farm assessment of soil quality and health. p. 83-105. In J.W. Doran and A.J. Jones (ed.) Methods for Assessing Soil Quality. SSSA Spec. Publ. 49. SSSA, Madison, WI.

Skousen, J.G., A. Sexstone, and P.F. Ziemkiewicz. 2000. Acid mine drainage control and treatment. Chapter 6. p. 131-168. In R.I. Barnhisel, R.G. Darmody, and W.L. Daniels (ed.) Reclamation of Drastically Disturbed Lands. American Society of Agronomy, Crop Science Society of Agronomy, Soil Science Society of Agronomy, Madison WI.

Silverman, M.P. 1967. Mechanism of bacterial pyrite oxidation. J. Bacteriology. 94:10461051. 
Singer, P.C., and W. Stumm. 1970. Acidic mine drainage: The rate-determining step. Science. 167:1121-1123.

Soil Survey Division. 2000. Hydric Soils Introduction. http://www.statlab.iastate.edu/soils/hydric/intro.html\#DEF.

Soil Survey Division. 2003. Soil Series Name Search. http://ortho.ftw.nrcs.usda.gov/cgibin/osd/osdnamequery.cgi.

Soil Survey Division Staff. 1993. Soil Survey Manual. USDA Handbook. No. 18. U.S. Gov. Print. Office, Washington, D.C.

Soil Survey Staff. 1996. Soil Survey Laboratory Methods Manual. Soil Survey Investigations Report No. 42. Version 3.0. USDA-NRCS. National Soil Survey Center, Lincoln, NE.

Soil Survey Staff. 1998. Keys to Soil Taxonomy. Eighth Edition. USDA-NRCS. Washington, D.C.

Soil Survey Staff. 1999. Soil Taxonomy. Agriculture Handbook No. 436. USDA-NRCS. U.S. Govt. Printing Office. Washington, DC.

Spratt, H.G. Jr, M.D. Morgan, and R.E. Good. 1987. Sulfate reduction in peat from a New Jersey pinelands cedar Swamp. App. Environ. Micro. 53:1406-1411.

Stark, L.R., F.M. Williams, S.E. Stevens, and D.P. Eddy. 1994. Iron retention and vegetative cover at the Simco constructed wetland: An appraisal through year eight of operation. p. 89-98. In Bur. Mines SP 06A-94. Proc. Int. Land Reclamat. Mine Drain. Conf., Pittsburgh, PA. 24-29 April. 1994. U.S. Dep. Int., Bur Mines, Pittsburgh, PA.

Stark, L.R., F.M. Williams, W.R. Wenerick, P.J. Wuest, and C. Urban. 1995. The effects of carbon supplementation and plant species on iron retention in mesocosm treatment wetlands. Wetlands. 15:58-67.

Stark, L.R., F.M. Williams, W.R. Wenerick, P.J. Wuest, and C. Urban. 1996. The effects of substrate type, surface water depth, and flow rate on manganese retention in mesocosm wetlands. J. Environ. Qual. 25:97-106.

Stumm, W. and J.J. Morgan. 1981. Aquatic chemistry. $2^{\text {nd }}$. Ed. John Wiley \& Sons Inc., New York.

Tarutis, Jr., W.J., and R.F. Unz. 1992. Behavior of sedimentary Fe and Mn in natural wetlands receiving acidic mine drainage, Pennsylvania, U.S.A.. Applied Geochemistry 7:77-85.

Tarutis, Jr., W.J., and R.F. Unz. 1996. Biogeochemical fate of coal mine drainage pollutants in constructed wetlands. Current Topics in Wetland Biogeochemistry 7:40-51. 
Tiner, R.W. 2001.Wetland definitions and classifications in the united states. http://water.usgs.gov/nwsum/WSP2425/defintions.html.

United States Department of Agriculture-Natural Resources Conservation Service. 1995, Changes in hydric soils of the U.S. Federal Register. Vol. 60 (37)/ Fri., Feb. 24. p. 103-149. U.S. Govt. Printing Office. Washington DC.

United States Department of Agriculture, Natural Resources Conservation Service. 1998. Field indicators of hydric soils in the United States. Version 4.0. G.W. Hurt, Whited, P.M., and Pringle, R.F. (9 eds). USDA, NRCS, Ft Worth, Texas.

Urlich, G.A, L.R. Krumholk, and J.M. Suflita. 1997. A rapid and simple method for estimating sulfate reduction activity and quantifying inorganic sulfides. App. and Env. Mic. 63: 1627-1630

Vepraskas, M.J., and S.P. Faulkner. 2001. Redox chemistry of wetland soils. Chapter 5. 85106. In Richardson, J.L., and M.J. Vepraskas (ed.) Wetland soils: genesis, hydrology, landscapes and classification. Lewis Publishers, Boca Raton, Florida.

Vepraskas, M.J., and L.P. Wilding. 1983. Aquic moisture regimes in soils with and without low chroma colors. Soil Sci. Soc. Am. J. 47:280-285.

Vile, M.A., and R.K. Wieder. 1993. Alkalinity generation by Fe(III) reduction verses sulfate reduction in wetlands constructed for acid mine drainage treatment. Water Air Soil Pollut. 69:425-441.

Wang, T., and J.H. Peverly. 1999. Iron oxidation states on root surfaces of a wetland plant. Soil Sci. Soc. Am. J. 63:247-252.

West Virginia University. 1995. Corridor H/ Blackwater River restoration. Unpublished report submitted to the West Virginia High Technology Consortium, WVHTC-F-S95-1011. Report is available from the West Virginia University National Research Center for Coal and Energy, Morgantown, WV.

Wieder, R.K. 1990. Metal cation binding to Sphagnum peat and sawdust: relation to wetland treatment of metal-polluted water. Water Air Soil Pollut. 53:391-400.

Wieder, R.K. 1993. Ion input/output budget for five wetlands constructed for acid coal mine drainage treatment. Water Air Soil Pollut. 71: 231-270.

Wieder, R.K., K.P. Heston, E.M. O’hara, G.E. Lang, A.E. Whitehouse, and J. Hett. 1988. Aluminum retention in a man-made Sphagnum wetland. Water Air Soil Pollut. 37: 177-191. 
Wieder, R.K., and G.E. Lang. 1984. Influence of wetlands and coal mining on stream water chemistry. Water Air Soil Pollut. 32:381-396.

Wieder, R.K., and G.E. Lang. 1986. Fe, Al, Mn and S chemistry of Sphagnum peat in four peatlands with different metal and sulfur input. Water Air Soil Pollut. 29:309-320.

Wieder, R.K., G.E. Lang, and V.A. Granus.1987. Sulphur transformations in Spahgnumderived peat during incubations. Soil Biol. Biochem. 19:101-106.

Wieder, R.K., M.N. Linton, and K.P. Heston. 1990. Laboratory mesocosm studies of Fe, Al, $\mathrm{Mn}, \mathrm{Ca}$, and $\mathrm{Mg}$ dynamics in wetlands exposed to synthetic acid coal mine drainage. Water Air Soil Pollut. 51:181-196.

Yavitt, J.B., D.M. Downey, E. Lancaster, and G.E. Lang. 1990. Methane consumption in decomposing Sphagnum-derived peat. Soil Bio. Biochem. 22:441-447. 
Appendices 
Appendix A

Soil Profile Descriptions 
Location: Tucker County, West Virginia, Beaver Creek Watershed.

Site: Narrow Wetland, stop1

Vegetation: Sphagnum moss

Physiography: Slightly sloping wetland

Surface Cover: No free water

Latitude: $39^{\circ} 09^{\prime} 30.1^{\prime \prime}$

Longitude: $79^{\circ} 25^{\prime} 22.1^{\prime \prime}$

Accuracy: $\pm 18 \mathrm{ft}$

Described and sampled by K. M. Stephens and J. Sencindiver, June 27, 2001.

Oi - 0 to $3 \mathrm{~cm}$; very dark brown ( 7.5 YR 2.5/2), sphagnum moss fibers, fine to medium roots.

A - 3 to $12 \mathrm{~cm}$; very dark gray (7.5YR 3/1) silt loam, few fine masses of strong brown (7.5YR 5/6) and gray (2.5Y 6/1), granular structure, many very fine to medium roots.

AB - 12 to $22 \mathrm{~cm}$; very dark gray (2.5Y 3/1) silt loam, common fine masses and pore linings of reddish yellow (7.5YR 6/6), granular structure, common very fine to medium roots.

Bg -22 to $35 \mathrm{~cm}$; grayish brown (2.5Y 5/2) silt loam, common fine and medium masses and pore linings of strong brown (7.5YR 5/6), subangular blocky structure, few very fine and fine roots.

Cg1-35-45 cm; grayish brown (2.5Y 5/2) silt loam, massive few very fine and fine roots.

Cg2-45-63 cm; low chroma silty clay loam.

2Cg3-63-68 cm; low chroma sandy loam.

2C1-68-75 cm; reddish yellow (7.5YR 6/8) sandy clay.

2C2-75-85 cm; olive brown (2.5Y 4/4) and light olive brown (2.5Y 5/3) clay, common medium masses gray (10YR 5/1).

2C3-85-110+ cm; reddish yellow (7.5 YR 6/8) clay.

Described by auger and peat sampler. 
Location: Tucker County, West Virginia, Beaver Creek Watershed.

Site: Narrow Wetland, stop 2

Vegetation: sedges

Physiography: Slightly sloping wetland

Surface cover: Free water present

Latitude: $39^{\circ} 09^{\prime} 30.6^{\prime \prime}$

Longitude: $79^{\circ} 25^{\prime} 23.6^{\prime \prime}$

Described and sampled by K. M. Stephens and J. Sencindiver, June 27, 2001.

Oi -0 to $5 \mathrm{~cm}$; very dark grayish brown (10YR 3/2), sedges, positive alpha, alphadipyridyl reaction.

A1 -5 to $15 \mathrm{~cm}$; dark gray (10YR 4/1) silt loam, common masses and pore linings of strong brown (7.5YR 5/6), granular structure, many very fine to medium roots, positive alpha, alpha-dipyridyl reaction.

A2 - 15 to $20 \mathrm{~cm}$; very dark gray (10YR 3/1) silt loam, granular structure, common very fine and fine roots, positive alpha, alpha-dipyridyl reaction.

Bg -20 to $35 \mathrm{~cm}$; dark gray (10YR 4/1) silt loam, few medium masses of olive brown (2.5YR 4/4), weak fine subangular structure, few very fine and fine roots, positive alpha, alpha-dipyridyl reaction.

Cg -35 to $45 \mathrm{~cm}$; dark gray (10YR 4/1) silt loam, massive, few very fine and fine roots, positive alpha, alpha-dipyridyl reaction.

$\mathbf{R}-45+\mathrm{cm}$.

Described and sampled by auger and peat sampler.

Appeared to be more AMD-impacted then stop 1. Iron oxides observed at bases of plants and at water level. There may be a thin Oe/Oa under the Oi that was to thin to sample. 
Location; Tucker County, West Virginia, Beaver Creek Watershed.

Site: Narrow Wetland, stop 3

Vegetation: sedges

Physiography: Slightly sloping wetland

Surface cover: Free water present

Latitude: $39^{\circ} 09^{\prime} 31.2^{\prime \prime}$

Longitude: $79^{\circ} 25^{\prime} 24.7^{\prime \prime}$

Accuracy: $\pm 13 \mathrm{ft}$

Described and sampled by K. M. Stephens and J. Sencindiver, June 27, 2001.

Oe -0 to $8 \mathrm{~cm}$; black (N 2.5/0).

A -8 to $10 \mathrm{~cm}$; very dark gray $(2.5 \mathrm{Y} 3 / 1)$ sandy loam, many very fine to medium roots.

Cg - 10 to $17 \mathrm{~cm}$; dark gray (2.5Y 4/1) silty clay loam, common fine and coarse (N $2.5 / 0)$ and (10YR 5/3), very fine to medium roots.

$\mathbf{A b}-17$ to $27 \mathrm{~cm}$; black (2.5Y 2.5/1) silt loam, many undecomposed roots and vegetation present in this horizon.

2Cg1 - 27 to $29 \mathrm{~cm}$; very dark gray (10YR 3/1) sandy loam.

2Cg2 - 29 to $40 \mathrm{~cm}$; very dark gray (10YR 3/1) loam, common very fine and fine roots.

2 Cg3 - 40 to $45 \mathrm{~cm}$; very dark gray (2.5Y 3/1) silt loam, few very fine and fine roots

$2 \mathrm{Cg} 4$ - 45 to $85 \mathrm{~cm}$; dark grayish brown (2.5Y 4/2) silty clay loam, very few very fine roots.

2 Cg5 - 85 to $100 \mathrm{~cm}$; very dark grayish brown (2.5Y 4/2) loam, few coarse masses of olive brown $(2.5 \mathrm{Y} 4 / 4)$.

3R $-100+\mathrm{cm}$.

Described by auger and peat sampler. 
Location; Tucker County, West Virginia, Beaver Creek Watershed.

Site: Narrow Wetland, stop 4

Vegetation: sedges

Physiography: Slightly sloping wetland

Surface cover: $70 \%$ free water impacted by acid mine drainage

Latitude: $39^{\circ} 09^{\prime} 32.0^{\prime \prime}$

Longitude: $79^{\circ} 25^{\prime} 25.6^{\prime \prime}$

Accuracy: $\pm 13 \mathrm{ft}$

Described and sampled by K. M. Stephens and J. Cross, June 28, 2001.

Oi1 - 0 to $3 \mathrm{~cm}$; dark reddish brown (5YR 3/4), sedges, positive alpha, alpha-dipyridyl reaction.

Oi2 -3 to $6 \mathrm{~cm}$; black (N 2.5/0), positive alpha, alpha-dipyridyl reaction.

Oe1 -6 to $15 \mathrm{~cm}$; very dark brown (10YR 2/2), positive alpha, alpha-dipyridyl reaction.

Oe2 -15 to $23 \mathrm{~cm}$; very dark grayish brown (10YR 3/2), positive alpha, alphadipyridyl reaction.

A -23 to $33 \mathrm{~cm}$; black (2.5Y 2.5/1), silty clay loam, common fine thin bands of dark yellowish brown (10YR 4/4), weak granular structure, many very fine to medium roots, positive alpha, alpha-dipyridyl reaction.

BA- 33 to $37 \mathrm{~cm}$; very dark gray (2.5Y 3/1) silt loam, weak subangular blocky structure, many very fine and fine roots, positive alpha, alpha-dipyridyl reaction.

Bg1 - 37 to $47 \mathrm{~cm}$; very dark grayish brown (2.5Y 3/2) silt loam/silty clay loam, moderate granular structure, many fine and fine roots, positive alpha, alpha-dipyridyl reaction.

Bg2 - 47 to $69 \mathrm{~cm}$; very dark grayish brown (2.5Y 3/2) loam, subangular blocky structure, few very fine and fine roots, positive alpha, alpha-dipyridyl reaction.

Cg -69 to $90+\mathrm{cm} ;(2.5 \mathrm{Y} \mathrm{3/2})$, sandy loam, massive, very few very fine and fine roots, positive alpha, alpha-dipyridyl reaction.

Described and sampled by auger and peat sampler.

Soil samples taken from under acid mine drainage impacted water. 
Location; Tucker County, West Virginia, Beaver Creek Watershed.

Site: Narrow Wetland, stop 5

Vegetation: mosses and few sedges

Physiography: Slightly sloping wetland

Surface Cover: Free water at surface

Latitude: $39^{\circ}$ ' $09^{\prime} 33.1^{\prime \prime}$

Longitude: $79^{\circ} 25^{\prime} 26.2^{\prime \prime}$

Accuracy: $\pm 25 \mathrm{ft}$

Described and sampled by K. M. Stephens and J. Cross, June 28, 2001.

Oi1 - 0 to $3 \mathrm{~cm}$; black (2.5Y 2.5/1), sphagnum moss, positive alpha, alpha-dipyridyl reaction.

Oi2 -3 to $6 \mathrm{~cm}$; olive brown (2.5Y 4/3), sphagnum moss, positive alpha, alphadipyridyl reaction.

Oi/Oe -6 to $12 \mathrm{~cm}$; dark yellowish brown (10YR 4/4), sphagnum moss, positive alpha, alpha-dipyridyl reaction.

A - 12 to $19 \mathrm{~cm}$; very dark gray (10YR 3/1) sandy loam/ loam, moderate granular structure, many very fine to medium roots, positive alpha, alpha-dipyridyl reaction.

Bg -19 to $28 \mathrm{~cm}$; very dark gray (10YR 3/1), sandy loam, weak subangular blocky structure, many very fine and fine roots, positive alpha, alpha-dipyridyl reaction.

$\mathbf{C g}-28$ to $65 \mathrm{~cm}$; very dark gray (10YR 3/1) loamy sand, common very fine to medium roots, positive alpha, alpha-dipyridyl reaction.

$2 \mathbf{R}-65+\mathrm{cm}$.

Described by auger and peat sampler. 
Location; Tucker County, West Virginia, Beaver Creek Watershed.

Site: Narrow Wetland, stop 6

Vegetation: Dominated by cattails and moss with few sedges

Physiography: Slightly sloping wetland

Surface Cover: Free water at surface

Latitude: $39^{\circ} 09^{\prime} 33.6^{\prime \prime}$

Longitude: $79^{\circ} 25^{\prime} 27.3^{\prime \prime}$

Accuracy: $\pm 24 \mathrm{ft}$

Described and sampled by K. M. Stephens and J. Cross, June 28, 2001.

Oi1 - 0 to $11 \mathrm{~cm}$; black (2.5Y 2.5/1), sphagnum moss, positive alpha, alpha-dipyridyl reaction.

Oi2 - 11 to $22 \mathrm{~cm}$; very dark gray ( $2.5 \mathrm{Y} 3 / 1)$, sphagnum moss, positive alpha, alphadipyridyl reaction.

Oi3 - 22 to $42 \mathrm{~cm}$; dark olive brown (2.5Y 3/3), sphagnum moss, positive alpha, alphadipyridyl reaction.

A1 - 42 to $53 \mathrm{~cm}$; very dark gray (10YR 3/1) silt loam/silty clay loam, many very fine to medium roots, positive alpha, alpha-dipyridyl reaction.

A2 -53 to $56 \mathrm{~cm}$; very dark gray (2.5Y 3/1) silt loam, granular structure, few very fine and fine roots, positive alpha, alpha-dipyridyl reaction.

C -56 to $60 \mathrm{~cm}$; dark gray (10YR 4/1) silty clay loam, few very fine to medium roots, positive alpha, alpha-dipyridyl reaction.

$\mathbf{A b}-60$ to $66 \mathrm{~cm}$; very dark gray (2.5Y 3/1) loam, granular structure, very few very fine and fine roots, positive alpha, alpha-dipyridyl reaction.

Bgb - 66 to $93 \mathrm{~cm}$; very dark grayish brown (10YR 3/2) silt loam, very few very fine and fine roots, subangular blocky structure, very few very fine and fine roots positive alpha, alpha-dipyridyl reaction.

$\mathbf{2 R}-93+\mathrm{cm}$.

Described and sampled by auger and peat sampler.

Lots of precipitated iron hydroxides in Oi1. 
Location; Tucker County, West Virginia, Beaver Creek Watershed.

Site: Iron Pond, stop 1

Vegetation: Sphagnum moss

Physiography: Narrow slightly sloping wetland

Surface Cover: Free water at surface

Latitude: $39^{\circ} 10^{\prime} 28.5^{\prime \prime}$

Longitude: $79^{\circ} 24^{\prime} 8.7^{\prime \prime}$

Accuracy: $\pm 17 \mathrm{ft}$

Described and sampled by K. M. Stephens, August 2, 2001.

$\mathbf{O i}-0$ to $7 \mathrm{~cm}$; dark brown (7.5YR 2.5/3), sphagnum moss.

Oe -7 to $9 \mathrm{~cm}$; dark brown (7.5YR 3/4).

A -9 to $13 \mathrm{~cm}$; dark yellowish brown (10YR 3/6) silt loam, many very fine to medium roots, positive alpha, alpha-dipyridyl reaction, very many moss fibers present in this horizon.

C -13 to $38 \mathrm{~cm}$; olive brown (10Y 2.5/0) silt loam, many very fine to medium roots, positive alpha, alpha-dipyridyl reaction, few moss fibers present in this horizon.

$2 \mathrm{C1}-38$ to $64 \mathrm{~cm}$; dark grayish brown $(2.5 \mathrm{Y} 4 / 2)$, many very fine to medium roots, positive alpha, alpha-dipyridyl reaction.

2C2 $-64+\mathrm{cm}$; dark grayish brown $(2.5 \mathrm{Y} 4 / 2)$ gravelly loamy sand, few very fine and fine roots, positive alpha, alpha-dipyridyl reaction.

Described and sampled by auger and peat sampler.

Soil was variable from spot to spot. 
Location; Tucker County, West Virginia, Beaver Creek Watershed.

Site: Iron Pond, stop 2

Vegetation: Cattails, mosses, and sedges

Physiography: Narrow slightly sloping wetland

Surface Cover: Free water at surface

Described and sampled by K. M. Stephens and M. Straud, August 2, 2001.

Oi1 - 0 to $10 \mathrm{~cm}$; dark yellowish brown (10YR 3/6), sphagnum moss fibers.

Oi2 - 10 to $16 \mathrm{~cm}$; dark reddish brown (5YR 3/4), sphagnum moss fibers.

Oi3 - 16 to $23 \mathrm{~cm}$; very dark grayish brown (2.5Y 3/2), sphagnum moss fibers.

A -23 to $45 \mathrm{~cm}$; black (N 2.5/0).

Bw -45 to $61 \mathrm{~cm}$; light olive brown (2.5Y 5/6) very gravelly loamy sand.

Ab -61 to $75 \mathrm{~cm}$; black (N 2.5/0).

Cgb -75 to $86 \mathrm{~cm}$; olive gray (5Y 4/2) loam.

Cb $-86+\mathrm{cm}(5 \mathrm{Y} 4 / 3)$ gravelly sandy loam, few fine masses of black (N 2.5/0).

Described and sampled by auger and peat sampler.

Lots of iron hydroxides present in Oi2. 
Location; Tucker County, West Virginia, Beaver Creek Watershed.

Site: Iron Pond, stop 3

Vegetation: mosses

Physiography: Narrow slightly sloping wetland

Latitude: $39^{\circ} 10^{\prime} 26.9^{\prime \prime}$

Longitude: $79^{\circ} 24^{\prime} 10.9^{\prime \prime}$

Accuracy: $\pm 16 \mathrm{ft}$

Described and sampled by K. M. Stephens and M. Straud, August 2, 2001.

Oi1 -0 to $4 \mathrm{~cm}$; sphagnum moss fibers.

Oi2 -4 to $8 \mathrm{~cm}$; dark reddish brown (5YR 3/4), sphagnum moss fibers.

Oi3 -8 to $17 \mathrm{~cm}$; dark reddish brown (2.5YR 2.5/4), sphagnum fibers.

Oi4 - 17 to $22 \mathrm{~cm}$; dark brown (7.5YR 3/4), partially decomposed sedges.

A - 22 to $28 \mathrm{~cm}$; greenish black (10Y 2.5/1) loam, common very fine to medium roots, positive alpha, alpha-dipyridyl reaction.

C1 -28 to $33 \mathrm{~cm}$; dark yellowish brown (10YR 4/6) loam, few very fine and fine roots, positive alpha, alpha- dipyridyl reaction.

C2 - 33 to $37 \mathrm{~cm}$; dark yellowish brown (10YR 3/4) sandy loam, few very fine and fine roots, positive alpha, alpha-dipyridyl reaction.

C3 - 37 to $54 \mathrm{~cm}$; olive gray $(2.5 \mathrm{Y} 4 / 3)$ sandy loam, few very fine and fine roots, positive alpha, alpha-dipyridyl reaction.

$2 \mathrm{Cg}-54+\mathrm{cm}$; dark greenish gray (10Y 4/1) silty clay loam, very few very fine roots, positive alpha, alpha-dipyridyl reaction.

Described and sampled with an auger and peat sampler. 
Location; Tucker County, West Virginia, Beaver Creek Watershed.

Site: Iron Pond, stop 4.

Physiography: Narrow slightly sloping wetland

Surface Cover: $10 \%$ free water at surface

Vegetation: mosses, sedges, and cattails

Described and sampled by K. M. Stephens and J. Cross, June 28, 2001.

Oi1 - 0 to $9 \mathrm{~cm}$; olive brown $(2.5 \mathrm{Y} 4 / 4)$.

Oi2 -9 to $21 \mathrm{~cm}$; dark yellowish brown (10YR 4/4).

A1- 21 to $25 \mathrm{~cm}$; black (N 2.5/0).

A2 -25 to $32 \mathrm{~cm}$; dark greenish gray (10Y 4/1).

AC -32 to $43 \mathrm{~cm}$; olive brown $(2.5 \mathrm{Y} 4 / 3)$ sandy clay loam.

C1 -43 to $71 \mathrm{~cm}$; olive brown $(2.5 \mathrm{Y} 4 / 3)$ clay loam/ silty clay loam, common masses of yellowish brown (10YR 5/8) and few masses of gray (10YR6/1), many very fine to medium roots.

C2 -71 to $94+\mathrm{cm}(2.5 \mathrm{Y} 3 / 3)$ very gravelly clay loam, common masses of yellowish brown (10YR 5/6).

Described and sampled by auger and peat sampler.

Acid mine drainage seep located very close this stop, yet it still has healthy looking vegetation. 
Location; Tucker County, West Virginia, Beaver Creek Watershed.

Site: Iron Pond, stop 5.

Physiography: Narrow slightly sloping wetland, near pond

Surface Cover: $20-30 \%$ Free water at surface

Vegetation: mosses, sedges, and cattails

Described and sampled by K. M. Stephens and J. Cross, June 28, 2001.

Oi1 - 0 to $9 \mathrm{~cm}$; dark olive brown $(2.5 \mathrm{Y} 3 / 3)$, sphagnum moss.

Oi2 -9 to $18 \mathrm{~cm}$; dark brown (7.5YR 3/4), sphagnum moss.

A -18 to $31 \mathrm{~cm}$; black (N 2.5/0).

AC -31 to $50 \mathrm{~cm}$; olive gray ( $5 \mathrm{Y} 4 / 2)$ loam, common masses of dark yellowish brown (10YR 4/6) and dark greenish gray (10Y 4/1), many very fine to medium roots.

Cg1 -50 to $64 \mathrm{~cm}$; greenish black (5GY 2.5/0).

Cg2 - 64 to $78 \mathrm{~cm}$; olive gray (5Y 4/2) very gravelly sandy loam, common masses of dark yellowish brown (10YR 4/6) and few fine concretions of black (N 2.5/0), massive.

Cg3 -78 to $108 \mathrm{~cm}(5 \mathrm{Y}$ 4/2) clay loam, massive, many fine masses of black (N 2.5/0) C3 $-108+$ cm olive (5Y 4/3) clay loam, massive.

Described and sampled by auger and peat sampler.

Acid mine drainage seep $150 \mathrm{ft}$ upslope form this site.

Standing water (small pond) $50 \mathrm{ft}$ down slope. 
Location: Tucker County, West Virginia, Beaver Creek Watershed.

Site: Railroad Grade, transect 1, stop 1

Physiography: Broad slightly sloping wetland

Surface Cover: No free water present

Vegetation: mosses, and sedges

Latitude: $39^{\circ} 09^{\prime} 55.0^{\prime \prime}$

Longitude: $79^{\circ} 25^{\prime} 9.7^{\prime \prime}$

Accuracy: $( \pm 19 \mathrm{ft})$

Described and sampled by K. M. Stephens and J. Cross, June 29, 2001.

Oi1 - 0 to $9 \mathrm{~cm}$; brown (10YR 4/3), sphagnum moss, positive alpha, alpha-dipyridyl reaction.

Oi2 -9 to $18 \mathrm{~cm}$; dark brown (7.5YR 3/3), sphagnum moss, positive alpha, alphadipyridyl reaction.

Oe -18 to $25 \mathrm{~cm}$; very dark brown (10YR 2/2), sphagnum moss, positive alpha, alphadipyridyl reaction.

Oa1 - 25 to $37 \mathrm{~cm}$; very dark brown (10YR 2/2), moderate granular structure, common very fine and fine roots, positive alpha, alpha-dipyridyl reaction.

A - 37 to $43 \mathrm{~cm}$; very dark brown (10YR 2/2), subangular blocky structure, common very fine and fine roots, positive alpha, alpha-dipyridyl reaction.

Cg1 -43 to $75 \mathrm{~cm}$; (2.5Y 5/2) silty clay loam common pore linings of strong brown (7.5YR 4/6), few very fine and fine roots, positive alpha, alpha-dipyridyl reaction.

Cg2 -75 to $92 \mathrm{~cm}(2.5 Y$ 5/2) silty clay loam, many fine and medium pore linings (7.5YR 4/6), massive, very few fine and very fine roots, positive alpha, alpha-dipyridyl reaction.

$\mathbf{2 R}-92+\mathrm{cm}$.

Described and sampled by auger and peat sampler. 
Location: Tucker County, West Virginia, Beaver Creek Watershed.

Site: Railroad Grade, transect 1, stop 2

Physiography: Broad slightly sloping wetland

Surface Cover: $25 \%$ free water

Vegetation: sedges and grasses

Latitude: $39^{\circ} 09^{\prime} 56.0^{\prime \prime}$

Longitude: $79^{\circ} 25^{\prime} 6.6$ "

Accuracy: $( \pm 13 \mathrm{ft})$

Described and sampled by K. M. Stephens and J. Cross, June 29, 2001. reaction.

Oi1 - 0 to $5 \mathrm{~cm}$; black (10YR 2/1), sphagnum moss, positive alpha, alpha-dipyridyl

Oi2 - 5 to $33 \mathrm{~cm}$; dark yellowish brown (10YR 3/4), sphagnum moss, positive alpha, alpha-dipyridyl reaction.

Oe -33 to $40 \mathrm{~cm}$; very dark brown (10YR 2/2), sphagnum moss, positive alpha, alphadipyridyl reaction.

Oa1 - 40 to $45 \mathrm{~cm}$; very dark brown (10YR 2/2), few fine masses of dark grayish brown $(2.5 \mathrm{Y} 4 / 2)$, moderate granular structure, common very fine to medium roots, positive, alpha, alpha-dipyridyl reaction.

Oa2 - 45 to $54 \mathrm{~cm}$; very dark brown (10YR 2/2), few fine masses of dark brown (7.5YR 3/4), moderate granular structure, common very fine and fine roots, positive alpha, alpha-dipyridyl reaction.

Cg1 - 54 to $72 \mathrm{~cm}$; grayish brown (2.5Y 5/2) silty clay loam, few masses of light brownish gray (10YR 6/2), very few very fine roots, positive alpha, alpha-dipyridyl reaction.

Cg2 - 72 to $82 \mathrm{~cm}$; very dark grayish brown (2.5Y 3/2), loam, many fine and medium pore linings of strong brown ( $7.5 \mathrm{YR} 4 / 6)$, massive, very few fine and very fine roots, positive alpha, alpha-dipyridyl reaction.

$2 \mathbf{R}-82+\mathrm{cm}$.

Described and sampled by auger and peat sampler. 
Location: Tucker County, West Virginia, Beaver Creek Watershed.

Site: Railroad Grade, transect 1, stop 3

Physiography: Broad slightly sloping wetland

Surface Cover: $15 \%$ free water

Vegetation: mosses, sedges and grasses

Latitude: $39^{\circ} 09^{\prime} 56.6^{\prime \prime}$

Longitude: $79^{\circ} 25^{\prime} 2.1^{\prime \prime}$

Accuracy: ( $\pm 14-17 \mathrm{ft})$

Described and sampled by K. M. Stephens and J. Schnably, July 5, 2001.

Oi1 - 0 to $5 \mathrm{~cm}$; very dark brown (7.5YR 2.5/3), sphagnum moss, positive alpha, alpha-dipyridyl reaction.

Oi2 -5 to $13 \mathrm{~cm}$; black (N 2.5/0), sphagnum moss, positive alpha, alpha-dipyridyl reaction.

Oe -13 to $23 \mathrm{~cm}$; very dark brown (10YR 2/2), positive alpha, alpha-dipyridyl reaction.

A -23 to $42 \mathrm{~cm}$; very dark gray (N 3/0), few fine masses of dark grayish brown (2.5Y $4 / 2$ ), moderate granular structure, common very fine to medium roots, positive, alpha, alphadipyridyl reaction.

Oa -42 to $47 \mathrm{~cm}$; black (2.5Y 2.5/1), few fine masses of dark brown (7.5YR 3/4), moderate granular structure, common very fine and fine roots, positive alpha, alpha-dipyridyl reaction.

Bg -47 to $62 \mathrm{~cm}$; very dark gray (2.5Y 3/1) silt loam, weak subangular blocky structure, common very fine and fine roots, positive alpha, alpha-dipyridyl reaction. .

C -62 to $81 \mathrm{~cm}$; dark yellowish brown (10YR 4/6) silty clay loam, many fine to medium masses of dark gray (10 YR 4/1), few very fine roots, positive alpha, alpha-dipyridyl reaction.

$\mathbf{2 R}-81+\mathrm{cm}$.

Described and sampled by auger and peat sampler 
Location: Tucker County, West Virginia, Beaver Creek Watershed.

Site: Railroad Grade, transect 1, stop 4

Physiography: Broad slightly sloping wetland

Surface Cover: $40 \%$ free water

Vegetation: mosses, sedges and grasses

Latitude: $39^{\circ} 09^{\prime} 56.5^{\prime \prime}$

Longitude: $79^{\circ} 24^{\prime} 59.1^{\prime \prime}$

Accuracy: $( \pm 24 \mathrm{ft})$

Described and sampled by K. M. Stephens and J. Schnably, July 5, 2001.

Oi1 - 0 to $3 \mathrm{~cm}$; black (N 2.5/0), sphagnum moss, positive alpha, alpha-dipyridyl reaction.

Oi2 -3 to $9 \mathrm{~cm}$; very dark gray ( 2.5 Y 3/1), sphagnum moss, positive alpha, alphadipyridyl reaction.

Oi3 - 9 to $13 \mathrm{~cm}$; black (N 2.5/0), sphagnum moss, positive alpha, alpha-dipyridyl reaction.

Oe -13 to $17 \mathrm{~cm}$; black (N 2.5/0), positive, alpha, alpha-dipyridyl reaction.

A -17 to $25 \mathrm{~cm}$; very dark gray (2.5Y 3/1) loam, positive alpha, alpha-dipyridyl reaction.

Cg -25 to $40 \mathrm{~cm}$; dark bluish gray (5PB 3/1) silty clay loam, common fine to medium masses of dark yellowish brown (10YR 4/6), positive alpha, alpha-dipyridyl reaction.

O'e -40 to $50 \mathrm{~cm}$; dark gray (10YR 4/1), positive alpha, alpha-dipyridyl reaction.

$\mathbf{C}^{\prime} \mathbf{g}-50$ to $54 \mathrm{~cm}$; very dark gray (2.5Y 3/1) sandy loam, positive alpha, alphadipyridyl reaction. .

Oa -54 to $66 \mathrm{~cm}$; (10YR 2/2), weak granular structure, common very fine and fine roots, positive alpha, alpha-dipyridyl reaction. .

C -66 to $87 \mathrm{~cm}$; olive brown (2.5 Y 4/4) silty clay loam, many fine to medium masses of dark gray (10 YR 4/1), few very fine and fine roots, positive alpha, alpha-dipyridyl reaction.

$\mathbf{C}^{\prime \prime} \mathbf{g}-87+\mathrm{cm}$; very dark gray (10YR 3/1) silty clay loam, few medium pore linings of dark brown (7.5YR 3/4), few very fine and fine roots, positive alpha, alpha-dipyridyl reaction.

Described and sampled by auger and peat sampler 
Location: Tucker County, West Virginia, Beaver Creek Watershed.

Site: Railroad Grade, transect 2, stop 1

Physiography: Broad slightly sloping wetland, heavily impacted by sediments and acid mine drainage

Surface Cover: $50 \%$ free water

Vegetation: St Johns wart, sundew, blueberry, mosses, and grasses

Latitude: $39^{\circ} 09^{\prime} 56.4^{\prime \prime}$

Longitude: $79^{\circ} 25^{\prime} 00.3^{\prime \prime}$

Accuracy: $( \pm 16 \mathrm{ft})$

Described and sampled by K. M. Stephens and J. Schnably, July 6, 2001. reaction.

Oi -0 to $7 \mathrm{~cm}$; dark yellowish brown (10YR 3/4), positive alpha, alpha-dipyridyl

Oe -7 to $18 \mathrm{~cm}$; black (N 2.5/0), positive alpha, alpha-dipyridyl reaction.

A -18 to $28 \mathrm{~cm}$; black (N 2.5/0), positive alpha, alpha-dipyridyl reaction.

Bg -28 to $45 \mathrm{~cm}$; dark grayish brown $(2.5 \mathrm{Y} 4 / 2)$ loam, few fine to medium masses of dark yellowish brown (10YR 4/6), many fine to medium masses of very dark gray (N 3/0), few medium masses of black ( $2.5 / 0)$, weak subangular blocky structure, many very fine and fine roots.

O'e1 - 45 to $56 \mathrm{~cm}$; black (N 2.5/0) gravelly loamy sand, few very fine and fine roots.

O'e2 - 56 to $66 \mathrm{~cm}$; black (2.5Y 2.5/1) silty clay loam.

O'e3 - 66 to $82 \mathrm{~cm}$; black (10YR 2/1).

Oa -82 to $100 \mathrm{~cm}$; black (7.5YR 2.5/1) silt loam, subangular blocky structure, few very fine roots.

$\mathbf{C}^{\prime} \mathbf{g} 1$ - 100 to112 cm; dark gray (2.5Y 4/1) silty clay loam, fine to coarse masses of $(2.5 \mathrm{Y} 4 / 3)$.

C'g2 - 112 to $124 \mathrm{~cm}$; very dark gray (10YR 3/1) silty clay loam, many fine to medium masses of dark yellowish brown (10YR 3/6).

$\mathbf{2 R}-124+\mathrm{cm}$.

Described and sampled by auger and peat sampler 
Location: Tucker County, West Virginia, Beaver Creek Watershed.

Site: Railroad Grade, transect 2, stop 2

Physiography: Broad slightly sloping wetland.

Surface Cover: $10 \%$ free water

Vegetation: St Johns wart, mosses, and sedges

Latitude: $39^{\circ} 09^{\prime} 55.1^{\prime \prime}$

Longitude: $79^{\circ} 25^{\prime} 03.0^{\prime \prime}$

Accuracy: $( \pm 17 \mathrm{ft})$

Described and sampled by K. M. Stephens and J. Schnably, July 6, 2001.

Oi -0 to $9 \mathrm{~cm}$; very dark brown (10YR $2 / 2)$, sphagnum moss.

Oe -9 to $16 \mathrm{~cm}$; very dark brown (10YR $2 / 2)$, positive alpha, alpha-dipyridyl reaction.

$\mathbf{O a}-16$ to $24 \mathrm{~cm}$; black (2.5Y 2.5/1), moderate medium granular structure, many very fine to medium roots, positive alpha, alpha-dipyridyl reaction.

Oa2 - 24 to $40 \mathrm{~cm}$; very dark gray (10YR 3/1) silt loam, weak fine to medium subangular blocky structure, many very fine to medium roots, positive alpha, alpha-dipyridyl reaction.

Bg -40 to $66 \mathrm{~cm}$; very dark gray $(2.5 \mathrm{Y} 3 / 1)$ silt loam, few fine pore linings of dark brown (7.5YR 3/4) and few fine masses of olive gray (2.5Y 5/2) and black (N 2.5/0), moderate medium subangular blocky structure, many very fine to medium roots, positive alpha, alphadipyridyl reaction.

2Cg1 - 66 to $100 \mathrm{~cm}$; very dark gray (10YR 3/1) sandy loam, positive alpha, alphadipyridyl reaction. .

2Cg2 - 100 to $130+$ cm dark olive gray (5Y 3/2) sandy loam, common masses of very dark gray (10YR 3/1), positive alpha, alpha-dipyridyl reaction.

Described and sampled by auger and peat sampler 
Location: Tucker County, West Virginia, Beaver Creek Watershed.

Site: Railroad Grade, transect 2, stop 3

Physiography: Broad slightly sloping wetland.

Surface Cover: No free water present

Vegetation: St Johns wart, mosses, and sedges

Latitude: $39^{\circ} 09^{\prime} 54.2^{\prime \prime}$

Longitude: $79^{\circ} 25^{\prime} 06.0^{\prime \prime}$

Accuracy: $( \pm 18 \mathrm{ft})$

Described and sampled by K. M. Stephens and J. Schnably, July 6, 2001.

Oi1 - 0 to $10 \mathrm{~cm}$; strong brown (7.5YR 4/6), sphagnum moss, many very fine to coarse roots.

. $\quad$ Oi2 -10 to $20 \mathrm{~cm}$; very dark brown (10YR 2/2), many very fine to coarse roots, positive alpha, alpha-dipyridyl reaction.

Oe -20 to $28 \mathrm{~cm}$; black (10YR 2/1), many very fine to coarse roots.

$\mathbf{O a}-28$ to $40 \mathrm{~cm}$; very dark gray $(2.5 \mathrm{Y} 3 / 1)$ silt loam, moderate fine to medium granular structure, many very fine to medium roots, positive alpha, alpha-dipyridyl reaction.

Bg1 - 40 to $60 \mathrm{~cm}$; very dark grayish brown (10YR 3/2) silt loam, many fine to medium masses of yellowish brown (10YR 5/6), common fine to medium masses of dark grayish brown (10YR 4/2), and few fine pore linings of dark brown (7.5YR 3/4), subangular blocky structure, common very fine to fine roots, positive alpha, alpha-dipyridyl reaction.

Bg2- 60 to $71 \mathrm{~cm}$; very dark gray (10YR 3/2) silt loam, common fine masses of strong brown (7.5YR 4/6), subangular blocky structure, few very fine to fine roots, positive alpha, alpha-dipyridyl reaction.

$$
\mathbf{R}-71+\mathrm{cm} \text {. }
$$

Described and sampled by auger and peat sampler

In some areas loamy sand $\mathrm{C}$ material is below the $\mathrm{Bg}$. 
Location: Tucker County, West Virginia, Beaver Creek Watershed.

Site: Elder Swamp; Alder Thicket, stop 1

Physiography: Slightly sloping wetland, near abandoned mine land.

Surface Cover: No free water present

Vegetation: Alder and grasses

Latitude: $39^{\circ} 11^{\prime} 54.5^{\prime \prime}$

Longitude: $79^{\circ} 21^{\prime} 19.2^{\prime \prime}$

Accuracy: $( \pm 18 \mathrm{ft})$

Described and sampled by K. M. Stephens and J. Schnably, July 15, 2001.

Oe -0 to $3 \mathrm{~cm}$; black (N 2.5/0), positive alpha, alpha-dipyridyl reaction.

. Oa1 -3 to $9 \mathrm{~cm}$; very dark brown (10YR 2/2), many very fine to coarse roots, positive alpha, alpha-dipyridyl reaction.

Oa2 - 9 to $19 \mathrm{~cm}$; very dark grayish brown (2.5Y 3/2) loam, moderate fine to medium granular structure, many very fine to coarse roots, positive alpha, alpha-dipyridyl reaction.

A - 19 to $32 \mathrm{~cm}$; dark grayish brown (2.5Y 4/2) silty clay loam, weak fine to medium subangular blocky structure breaking to weak fine granular, few very fine to fine roots, positive alpha, alpha-dipyridyl reaction.

Bg1 - 32 to $54 \mathrm{~cm}$; dark grayish brown $(2.5 \mathrm{Y} 4 / 2)$ silty clay loam, moderate medium subangular blocky structure, few very fine roots, positive alpha, alpha-dipyridyl reaction.

Bg2 - 54 to $60 \mathrm{~cm}$; very dark grayish brown $(2.5 \mathrm{Y} 3 / 2)$ silty clay loam, weak subangular blocky structure, few very fine roots, positive alpha, alpha-dipyridyl reaction.

Bg3 - 60 to $90 \mathrm{~cm}$; dark grayish brown (2.5Y 4/2) silt loam, weak subangular blocky structure, few very fine roots, positive alpha, alpha-dipyridyl reaction.

Ab- 90 to $108 \mathrm{~cm}$; very dark brown (10YR 2/2) silt loam, subangular blocky structure, few very fine roots, positive alpha, alpha-dipyridyl reaction.

$\mathbf{2 C g}-108+\mathrm{cm}$; very dark gray (10Y 3/1), sandy clay loam, massive, positive alpha, alpha-dipyridyl reaction.

Described and sampled by auger and peat sampler 
Location: Tucker County, West Virginia, Beaver Creek Watershed.

Site: Elder Swamp; Alder Thicket, stop 2

Physiography: Slightly sloping wetland, near abandoned mine land.

Surface Cover: No free water present

Vegetation: Alder, grasses

Latitude: $39^{\circ} 11^{\prime}$ '55.6"

Longitude: $79^{\circ} 21^{\prime} 19.7^{\prime \prime}$

Accuracy: $( \pm 21 \mathrm{ft})$

Described and sampled by K. M. Stephens and J. Schnably, July 15, 2001.

Oe1 -0 to $2 \mathrm{~cm}$; black (N 2.5/0).

Oe2 -2 to $7 \mathrm{~cm}$; very dark brown ( $7.5 \mathrm{YR} 2.5 / 2)$, many very fine to coarse roots.

A -7 to $13 \mathrm{~cm}$; dark brown $(2.5 \mathrm{Y} 3 / 2)$ loam, moderate fine to medium granular structure, many very fine to coarse roots, positive alpha, alpha-dipyridyl reaction.

Bg1 - 13 to $40 \mathrm{~cm}$; brown (2.5Y 4/2) silty clay loam, moderate fine to medium subangular blocky structure, many very fine to coarse roots, positive alpha, alpha-dipyridyl reaction.

Bg2 - 40 to $59 \mathrm{~cm}$; dark brown (2.5 Y 3/2) silty clay loam, moderate fine to medium subangular blocky structure, many very fine to medium roots, positive alpha, alpha-dipyridyl reaction.

Bg3 - 59 to $69 \mathrm{~cm}$; brown (2.5Y 4/2) silty clay loam, moderate subangular blocky structure, few very fine and fine roots, positive alpha, alpha-dipyridyl reaction.

Ab - 69 to $100 \mathrm{~cm}$; very dark grayish brown (10YR 3/2) silt loam, moderate subangular blocky structure, few very fine roots, positive alpha, alpha-dipyridyl reaction.

$\mathbf{2 C g}-100+\mathrm{cm}$; dark gray $(2.5 \mathrm{Y} 4 / 1)$ sandy clay loam, massive, few very fine roots, positive alpha, alpha-dipyridyl reaction.

Described and sampled by auger and peat sampler 
Location: Tucker County, West Virginia, Beaver Creek Watershed.

Site: Elder Swamp; Alder Thicket, stop 3

Physiography: Slightly sloping wetland, near abandoned mine land.

Surface Cover: No free water present

Vegetation: Alder, grasses, few Cattails

Latitude: $39^{\circ} 11^{\prime} 56.1^{\prime \prime}$

Longitude: $79^{\circ} 21^{\prime} 19.1^{\prime \prime}$

Accuracy: $( \pm 18 \mathrm{ft})$

Described and sampled by K. M. Stephens and J. Schnably, July 15, 2001.

Oe -0 to $3 \mathrm{~cm}$; very dark brown (10YR 2/2).

Oa1 -3 to $18 \mathrm{~cm}$; black (10YR 2/1), many very fine to medium roots.

Oa2 -18 to $25 \mathrm{~cm}$; black $(2.5 \mathrm{Y} 2 / 1)$, many very fine to medium roots.

Oa3 -25 to $34 \mathrm{~cm}$; very dark gray $(2.5 \mathrm{Y} 3 / 1)$ loam, moderate fine to medium granular structure, many very fine to medium roots, few pieces of charred timbers, positive alpha, alpha-dipyridyl reaction.

BA - 34 to $45 \mathrm{~cm}$; very dark gray (2.5 Y 3/1) silt loam, weak medium subangular blocky structure breaking to weak fine granular, many very fine and fine roots, positive alpha, alpha-dipyridyl reaction.

Bg1 - 45 to $62 \mathrm{~cm}$; very dark gray $(2.5 \mathrm{Y} 3 / 1)$ silt loam, masses of dark grayish brown $(2.5 \mathrm{Y} 4 / 2)$ and few nodules of black (N 2.5/0), many very fine and fine roots, positive alpha, alpha-dipyridyl reaction.

Bg2 - 62 to $94 \mathrm{~cm}$; very dark grayish brown (10YR 3/2) silty clay loam, few fine nodules of black ( $\mathrm{N} 2.5 / 0)$, few very fine roots, positive alpha, alpha-dipyridyl reaction.

$\mathbf{2 C g}-94+\mathrm{cm}$; very dark gray (10YR 3/2) sandy clay loam, few pore linings of dark gray (10YR 4/1), massive, few very fine roots, positive alpha, alpha-dipyridyl reaction.

Described and sampled by auger and peat sampler 
Location: Tucker County, West Virginia, Beaver Creek Watershed.

Site: Elder Swamp; Forested Wetland, stop 2

Physiography: Slightly sloping wetland, near abandoned mine land.

Surface Cover: No free water present

Vegetation: Alder, Balsom Fur, blueberry, and mosses

Latitude: $39^{\circ} 12^{\prime}$ '04.3"

Longitude: $79^{\circ} 21^{\prime} 13.7^{\prime \prime}$

Accuracy: $( \pm 25 \mathrm{ft})$

Described and sampled by K. M. Stephens and J. Schnably, July 18, 2001.

Oe -0 to $4 \mathrm{~cm}$; very dark brown (10YR $2 / 2)$, many very fine to medium roots, abrupt wavy boundary.

Oa -4 to $6 \mathrm{~cm}$; very dark brown (10YR 2/2) silt loam, weak granular structure, very friable, many very fine to medium roots, abrupt wavy boundary.

E -6 to $10 \mathrm{~cm}$; brown (10YR 5/3) silty clay loam, few masses of dark grayish brown (10YR 4/2) and few pore linings of strong brown (7.5YR 4/6), weak fine to coarse subangular blocky structure, friable, common very fine to coarse roots, abrupt wavy boundary.

BEg - 10 to $20 \mathrm{~cm}$; very dark brown (10YR 4/2) silt loam, few fine nodules black (N 2.5/0) and few fine masses of red (5YR 5/8), weak fine and medium subangular blocky structure breaking to weak fine and medium granular, friable, common very fine to coarse roots, abrupt wavy boundary.

Btg1 -20 to $32 \mathrm{~cm}$; very dark gray ( 2.5 Y 3/1) cobbly silty clay loam, pore linings of yellowish brown (10YR 5/8), weak medium prismatic structure breaking to moderate fine and medium subangular blocky, firm, few very fine and fine roots along ped faces, gradual wavy boundary.

Btg2 - 32 to $65 \mathrm{~cm}$; gray (10YR 5/1) cobbly silty clay loam, common masses of yellowish brown (10YR 5/6), weak coarse prismatic structure breaking to weak fine and medium subangular blocky, firm, few very fine roots along ped faces, abrupt wavy boundary.

Btxg -65 to $90 \mathrm{~cm}$; black (N 2.5/0) cobbly sandy clay loam, many fine masses of strong brown (7.5YR 4/6), moderate prismatic structure, firm.

$\mathbf{C g}-90$ to $150+\mathrm{cm}$; black (N 2.5/0) sandy clay loam, massive, positive alphadipyridyl reaction.

$\mathbf{2 R}-150+\mathrm{cm}$.

Last two horizons described and sampled by auger. 
Location: Tucker County, West Virginia, Beaver Creek Watershed.

Site: Elder Swamp; Forested Wetland, stop 1

Physiography: Slightly sloping wetland, near abandoned mine land.

Surface Cover: No free water present

Vegetation: Alder, Balsom Fur, ground Pine, Blueberry, and mosses

Latitude: $39^{\circ} 12^{\prime}$ '03.4"

Longitude: $79^{\circ} 21^{\prime} 12.9^{\prime \prime}$

Accuracy: $( \pm 19 \mathrm{ft})$

Described and sampled by K. M. Stephens and J. Schnably, July 18, 2001.

Oe -0 to $7 \mathrm{~cm}$; very dark brown (10YR 2/2), many very fine to medium roots, gradual wavy boundary.

A1 - 7 to $11 \mathrm{~cm}$; black (10YR 2/1), many very fine to coarse roots, abrupt wavy boundary.

A2 - 11 to $16 \mathrm{~cm}$; very dark gray (10YR 3/1) cobbly silt loam, weak medium subangular blocky structure breaking to moderate fine and medium granular structure, friable, many very fine to coarse roots, abrupt wavy boundary.

$\mathbf{E}-16$ to $23 \mathrm{~cm}$; dark gray (10YR 4/1) cobbly silt loam, few pore linings of dark brown (7.5YR 3/4), moderate fine and medium subangular blocky structure, friable, common very fine to medium roots, gradual wavy boundary.

BE - 23 to $34 \mathrm{~cm}$; yellowish brown (10YR 5/6) gravelly loam, coarse pore linings of dark gray (10YR 4/1), moderate medium prismatic structure, firm, gradual wavy boundary.

Bt -34 to $50 \mathrm{~cm}$; yellowish brown (10YR 5/8) gravelly silty clay loam, few coarse masses of strong brown (7.5YR 5/8) and dark gray (10YR 4/1) along ped faces, weak coarse prismatic structure breaking to moderate medium subangular blocky, firm.

Btxg - 50 to $123 \mathrm{~cm}$; very dark gray (10YR 3/1) gravelly sandy loam, common medium masses of yellowish brown (10YR 5/8), moderate prismatic structure, firm.

$\mathbf{C g}-123+\mathrm{cm}$; very dark gray (N 3/0) sandy clay loam, few masses of yellowish brown (10YR 5/8), massive, positive alpha-dipyridyl reaction.

Last two horizons described and sampled by auger. 
Location: Tucker County, West Virginia, Beaver Creek Watershed.

Site: Elder Swamp; Scrub Shrub, stop 1

Physiography: Moderately sloping wetland, near abandoned mine land.

Surface Cover: No free water present

Vegetation: Wild Raisin, Blueberry, Ground Pine, and mosses

Latitude: $39^{\circ} 12^{\prime} 03.2^{\prime \prime}$

Longitude: $79^{\circ} 21^{\prime} 00.9^{\prime \prime}$

Accuracy: $( \pm 15 \mathrm{ft})$

Described and sampled by K. M. Stephens and J. Schnably, July 18, 2001.

Oa -0 to $4 \mathrm{~cm}$; very dark brown (10YR 2/2) cobbly, many very fine to coarse roots, abrupt wavy boundary.

A -4 to $9 \mathrm{~cm}$; very dark grayish brown (2.5Y $3 / 2)$ cobbly silt loam, moderate fine and medium granular structure, very friable, many very fine to coarse roots, gradual wavy boundary.

BAg - 9 to $42 \mathrm{~cm}$; very dark grayish brown (10YR 3/2) cobbly silt loam, few fine masses of dark yellowish brown (10YR 4/6) and grayish brown (10YR 5/2), weak fine and medium subangular blocky structure, friable, common very fine to medium roots, abrupt wavy boundary.

Btg -42 to $67 \mathrm{~cm}$; dark gray (10YR 4/1) gravelly silty clay loam, light yellowish gray (10YR 6/2) along ped faces, weak medium prismatic structure breaking to weak medium subangular blocky, firm, few very fine and fine roots, gradual wavy boundary.

Btxg -67 to $83 \mathrm{~cm}$; strong brown (7.5YR 5/8) and gray (10YR 5/1) gravelly silty clay loam, moderate medium prismatic structure, very firm, gradual wavy boundary, few very fine roots.

Btx $-83+\mathrm{cm}$; dark yellowish brown (10YR 4/4), pore linings of yellowish brown (10YR 5/8) and dark gray (10YR 4/1).

Last two horizons described and sampled by auger. 
Location: Tucker County, West Virginia, Beaver Creek Watershed.

Site: Elder Swamp; Scrub Shrub, stop 2

Physiography: Moderately sloping wetland, near abandoned mine land.

Surface Cover: No free water present

Vegetation: mosses, fern, Wild Raisin, St Johns wart

Latitude: $39^{\circ} 12^{\prime} 00.6^{\prime \prime}$

Longitude: $79^{\circ} 21^{\prime} 00.0^{\prime \prime}$

Accuracy: $( \pm 13 \mathrm{ft})$

Described and sampled by K. M. Stephens and J. Schnably, July 18, 2001.

Oa -0 to $9 \mathrm{~cm}$; black (10YR 2/1) cobbly, many very fine to medium roots, abrupt wavy boundary.

A - 9 to $14 \mathrm{~cm}$; very dark gray (10YR 3/1) cobbly silt loam, moderate fine and medium granular structure, very friable, many very fine to medium roots, abrupt wavy boundary.

AE - 14 to $19 \mathrm{~cm}$; (10YR 4/1) cobbly silt loam, few fine masses of yellowish brown (10YR 5/6), moderate medium subangular blocky structure, friable, many very fine and fine roots, abrupt wavy boundary.

E - 19 to $24 \mathrm{~cm}$; grayish brown (10YR 5/2) loam, weak fine and medium subangular blocky structure, friable, many very fine and fine roots, abrupt wavy boundary.

Bt -24 to $48 \mathrm{~cm}$; yellowish brown (10YR 5/6) gravelly silty clay loam, dark gray (10YR 4/1) along ped faces, weak coarse prismatic structure breaking to moderate fine to coarse subangular blocky, firm, few very fine roots, gradual wavy boundary.

Btxg - 48 to $80 \mathrm{~cm}$; yellowish brown (10YR 5/6) and dark gray (10YR 4/1) gravelly silty clay loam, pore linings of gray (10YR 6/1), moderate medium prismatic structure, very firm, few very fine roots.

Btx $-80+\mathrm{cm}$; dark yellowish brown (10YR 4/4) clay loam, common fine pore linings of dark gray (10YR 4/1) and strong brown (7.5YR 5/6), very firm.

Last two horizons described and sampled by auger. 
Location: Tucker County, West Virginia, Beaver Creek Watershed.

Site: Elder Swamp; Fen-Marsh, transect 1, stop 1

Physiography: Slightly sloping fen

Surface Cover: No free water present

Vegetation: Wild Raisin, sedges, St. Johns Wort, grasses, and mosses

Latitude: $39^{\circ} 11^{\prime} 57.1^{\prime \prime}$

Longitude: $79^{\circ} 20^{\prime} 55.5^{\prime \prime}$

Accuracy: $( \pm 17 \mathrm{ft})$

Described and sampled by K. M. Stephens and J. Schnably, July 20, 2001.

Oi -0 to $21 \mathrm{~cm}$; very dark brown (10YR $2 / 2)$, moss, gradual wavy boundary.

Oi/Oe -21 to $28 \mathrm{~cm}$; black (10YR 2/1), abrupt wavy boundary, positive alphadipyridyl reaction.

Oa1 -28 to $38 \mathrm{~cm}$; very dark brown (10YR $2 / 2)$, common very fine to medium roots, abrupt wavy boundary, positive alpha-dipyridyl reaction.

$\mathbf{0 a 2}-38$ to $45 \mathrm{~cm}$; black (2.5Y 2.5/1), weak fine granular structure, friable, common very fine to medium roots, abrupt wavy boundary, positive alpha-dipyridyl reaction.

Oa3 - 45 to $56 \mathrm{~cm}$; very dark grayish brown (10YR 3/2), common fine and medium masses of olive yellow (2.5Y 6/6) along root channels, weak fine and medium subangular blocky structure, friable, common very fine and fine roots, abrupt wavy boundary, positive alpha-dipyridyl reaction.

Oa4 - 56 to $90 \mathrm{~cm}$; dark grayish brown (2.5Y 4/2), weak subangular blocky structure, friable, positive alpha-dipyridyl reaction.

Cg -90 to $130+\mathrm{cm}$; gray (2.5Y 5/1) silty clay loam, massive, positive alpha-dipyridyl reaction.

Last two horizons described and sampled by auger. 
Location: Tucker County, West Virginia, Beaver Creek Watershed.

Site: Elder Swamp; Fen-Marsh, transect 1, stop 2

Physiography: Flat Marsh

Surface Cover: Free water present

Vegetation: Cattails and mosses

Latitude: $39^{\circ} 11^{\prime} 58.0^{\prime \prime}$

Longitude: $79^{\circ} 20^{\prime} 56.2^{\prime \prime}$

Accuracy: $( \pm 15 \mathrm{ft})$

Described and sampled by K. M. Stephens and J. Schnably, July 20, 2001.

Oe1 -0 to $8 \mathrm{~cm}$; very dark brown (10YR $2 / 2$ ), many very fine to coarse roots, abrupt wavy boundary.

Oe2 -8 to $16 \mathrm{~cm}$; black (N 2.5/0), many very fine to coarse roots, abrupt wavy boundary, positive alpha, alpha-dipyridyl reaction.

. Oa1 - 16 to $32 \mathrm{~cm}$; dark brown (10YR 3/3), many very fine to coarse roots, positive alpha, alpha-dipyridyl reaction.

Oa2 - 32 to $41 \mathrm{~cm}$; very dark brown (10YR $2 / 2)$, many very fine to coarse roots, positive alpha, alpha-dipyridyl reaction.

Oa3 - 41 to $73 \mathrm{~cm}$; black (10YR 2/1), weak subangular blocky structure, friable, few very fine and fine roots, positive alpha, alpha-dipyridyl reaction.

Bg -73 to $98 \mathrm{~cm}$; very dark grayish brown (10YR 3/2), moderate subangular blocky structure, friable, few very fine and fine roots, positive alpha, alpha-dipyridyl reaction.

Cg1 - 98 to $124 \mathrm{~cm}$; very dark grayish brown (2.5Y 3/2) sandy loam, massive, positive alpha, alpha-dipyridyl reaction.

Cg2 - $124+$ cm; dark gray (2.5Y 4/1) loamy sand, massive, positive alpha, alphadipyridyl reaction.

Last two horizons described and sampled by auger. 
Location: Tucker County, West Virginia, Beaver Creek Watershed.

Site: Elder Swamp; Fen-Marsh, transect 2, stop 1

Physiography: Flat Marsh

Surface Cover: Free water present

Vegetation: $60 \%$ Cattails, Wild Raisin, sedges, and mosses

Latitude: $39^{\circ} 12^{\prime} 2.4^{\prime \prime}$

Longitude: $79^{\circ} 20^{\prime} 47.5^{\prime \prime}$

Accuracy: $( \pm 17 \mathrm{ft})$

Described and sampled by K. M. Stephens and M. Straud, August 2, 2001.

Oi -0 to $4 \mathrm{~cm}$; very dark brown (10YR 2/2).

Oe1 -4 to $11 \mathrm{~cm}$; very dark grayish brown (10YR 3/2), many very fine to medium roots, positive alpha, alpha-dipyridyl reaction.

Oe2 -11 to $42 \mathrm{~cm}$; very dark gray $(2.5 \mathrm{Y} 3 / 1)$, many very fine to medium roots.

Oa1 -42 to $56 \mathrm{~cm}$; very dark gray $(2.5 \mathrm{Y} 3 / 1)$, granular structure, many very fine and fine roots.

Oa2 -56 to $74 \mathrm{~cm}$; black (10YR 2/1), weak subangular blocky structure breaking to granular, many very fine and fine roots.

Oa3 - 74 to $107 \mathrm{~cm}$; very dark brown (10YR 2/2), subangular blocky structure, common very fine roots.

Oa4 $-107+\mathrm{cm}$; very dark grayish brown $(2.5 \mathrm{Y} 3 / 2)$, subangular blocky structure, positive alpha, alpha-dipyridyl reaction.

Described and sampled by auger and peat sampler. 
Location: Tucker County, West Virginia, Beaver Creek Watershed.

Site: Elder Swamp; Fen-Marsh, transect 2, stop 2

Physiography: Flat Marsh

Surface Cover: Free water present

Vegetation: Cattails, Wild Raisin, sedges, and mosses

Latitude: $39^{\circ} 12^{\prime} 1.2^{\prime \prime}$

Longitude: $79^{\circ} 20^{\prime} 46.7^{\prime \prime}$

Accuracy: $( \pm 13 \mathrm{ft})$

Described and sampled by K. M. Stephens and M. Straud, August 2, 2001.

Oi -0 to $5 \mathrm{~cm}$; very dark brown (10YR $2 / 2)$.

Oe1 -5 to $15 \mathrm{~cm}$; very dark brown $(7.5 \mathrm{YR} 2.5 / 3)$, many very fine to coarse roots.

Oe2 -15 to $25 \mathrm{~cm}$; dark brown $(7.5 \mathrm{Y} 3 / 2)$, many very fine to coarse roots.

Oa1 -25 to $53 \mathrm{~cm}$; black (10YR 2/1), granular structure, common very fine to coarse roots, positive alpha, alpha-dipyridyl reaction.

Oa2 -53 to $84+\mathrm{cm}$; very dark brown (10YR $2 / 2)$, common very fine to coarse roots, positive alpha, alpha-dipyridyl reaction.

Described and sampled by auger and peat sampler. 
Location: Tucker County, West Virginia, Beaver Creek Watershed.

Site: Elder Swamp; Fen-Marsh, transect 2, stop 3

Physiography: Slightly sloping fen

Surface Cover: Free water present

Vegetation: Sphagnum moss, Polytrichium mosses, and Wild Raisin

Latitude: $39^{\circ} 12^{\prime} 0.7^{\prime \prime}$

Longitude: $79^{\circ} 20^{\prime} 45.7^{\prime \prime}$

Accuracy: $( \pm 15 \mathrm{ft})$

Described and sampled by K. M. Stephens and M. Straud, August 2, 2001.

Oe1 - 0 to $4 \mathrm{~cm}$; dark yellowish brown (10YR 3/6), moss, positive alpha, alphadipyridyl reaction.

Oe2 -4 to $21 \mathrm{~cm}$; very dark brown (7.5YR 2.5/3), moss, positive alpha, alphadipyridyl reaction.

Oa1 -21 to $31 \mathrm{~cm}$; very dark gray $(2.5 \mathrm{Y} 3 / 1)$, common very fine to medium roots.

Oa2 -31 to $47 \mathrm{~cm}$; black (10YR 2/1), weak subangular blocky structure breaking to granular, few very fine to medium roots.

Oa3 -47 to $83 \mathrm{~cm}$; very dark brown (10YR 2/2), weak subangular blocky structure, few very fine to fine roots.

Oa4 - 83 -to $120+\mathrm{cm}$; black (2.5Y 2.5/1), subangular blocky structure very few very fine roots.

Described and sampled by auger and peat sampler. 
Location: Tucker County, West Virginia, Beaver Creek Watershed, Elder Swamp.

Site: Elder Swamp; Fen-Marsh, transect 2, stop 4

Physiography: Slightly sloping fen

Surface Cover: Free water present

Vegetation: Sphagnum and Polytrichium mosses, sedges, and Wild Raisin

Latitude: $39^{\circ} 12^{\prime} 59.9^{\prime \prime}$

Longitude: $79^{\circ} 20^{\prime} 44.7^{\prime \prime}$

Accuracy: $( \pm 16 \mathrm{ft})$

Described and sampled by K. M. Stephens and M. Straud, August 2, 2001.

Oi1 - 0 to $12 \mathrm{~cm}$; black (10YR 2/1), moss, many very fine to medium roots, positive alpha, alpha-dipyridyl reaction.

Oi2 - 12 to $23 \mathrm{~cm}$; very dark brown (7.5YR 2.5/3), moss, many very fine to medium roots, positive alpha, alpha-dipyridyl reaction.

$\mathbf{O e}-22$ to $33 \mathrm{~cm}$; dark yellowish brown (10YR 3/4), many very fine to medium roots, positive alpha, alpha-dipyridyl

Oa1 - 33 to $43 \mathrm{~cm}$; black (2.5Y 2.5/1), granular structure, many very fine to medium roots, positive alpha, alpha-dipyridyl reaction.

Oa2 -43 to $68 \mathrm{~cm}$; black (10YR 2/1), weak subangular blocky structure breaking to granular, common very fine and fine roots, positive alpha, alpha-dipyridyl reaction.

Oa3 - 68 to $90 \mathrm{~cm}$; very dark brown (7.5YR 2.5/2), weak subangular blocky structure, common very fine roots, positive alpha, alpha-dipyridyl reaction.

Oa4- 90 to $112 \mathrm{~cm}$; black (10YR 2/1), weak subangular blocky structure, very few very fine roots, positive alpha, alpha-dipyridyl reaction.

$\mathbf{C g}-112$ to $133+\mathrm{cm}$; grayish brown (2.5Y 5/2) silty clay loam, massive, positive alpha, alpha-dipyridyl reaction.

Described and sampled by auger and peat sampler. 
Appendix B

Particle Size Distribution 
Table 8. Particle size distribution and textural class for soils in all wetlands.

\begin{tabular}{|c|c|c|c|c|c|c|c|c|c|c|c|}
\hline \multirow[t]{2}{*}{ Stop } & \multirow[t]{2}{*}{ Soil Type } & \multirow{2}{*}{$\begin{array}{c}\text { Sample } \\
\text { Depth } \\
\text { cm }\end{array}$} & $\begin{array}{l}\text { Very Coarse } \\
\text { Sand }\end{array}$ & $\begin{array}{l}\text { Coarse } \\
\text { Sand }\end{array}$ & $\begin{array}{l}\text { Medium } \\
\text { Sand }\end{array}$ & $\begin{array}{l}\text { Fine } \\
\text { Sand }\end{array}$ & $\begin{array}{l}\text { Very Fine } \\
\text { Sand }\end{array}$ & Sand & Silt & Clay & \multirow[t]{2}{*}{ Class* } \\
\hline & & & \multicolumn{8}{|c|}{$\%$} & \\
\hline \multicolumn{12}{|c|}{ Narrow Wetland } \\
\hline 2 & $\begin{array}{l}\text { Oi } \\
\text { M1 } \\
\text { M2 } \\
\text { M3 }\end{array}$ & $\begin{array}{c}0-5 \\
5--15 \\
15--35 \\
35--65 \\
\end{array}$ & $\begin{array}{l}-- \\
0.0 \\
0.0 \\
0.2\end{array}$ & $\begin{array}{l}-- \\
0.0 \\
0.1 \\
0.0\end{array}$ & $\begin{array}{l}-- \\
0.1 \\
0.3 \\
1.2\end{array}$ & $\begin{array}{c}-- \\
0.4 \\
6.2 \\
12.7\end{array}$ & $\begin{array}{c}-- \\
1.0 \\
11.2 \\
16.4\end{array}$ & $\begin{array}{c}-- \\
1.5 \\
18.0 \\
31.0\end{array}$ & $\begin{array}{c}-- \\
51.0 \\
54.3 \\
51.3 \\
\end{array}$ & $\begin{array}{c}-- \\
47.5 \\
27.7 \\
17.8 \\
\end{array}$ & $\begin{array}{c}-- \\
\text { SiC } \\
\text { SiCL } \\
\text { SiL }\end{array}$ \\
\hline 4 & $\begin{array}{l}\text { Oi } \\
\text { Oe } \\
\text { Oe } \\
\text { M1 } \\
\text { M2 } \\
\text { M3 } \\
\end{array}$ & $\begin{array}{c}0--6 \\
6--15 \\
15--23 \\
23--33 \\
33--53 \\
53--83 \\
\end{array}$ & $\begin{array}{l}-- \\
-- \\
-- \\
0.1 \\
0.0 \\
0.3 \\
\end{array}$ & $\begin{array}{l}-- \\
-- \\
-- \\
0.3 \\
0.3 \\
1.0\end{array}$ & $\begin{array}{l}-- \\
-- \\
-- \\
1.0 \\
2.4 \\
4.5 \\
\end{array}$ & $\begin{array}{c}-- \\
-- \\
-- \\
3.4 \\
13.2 \\
15.6 \\
\end{array}$ & $\begin{array}{c}-- \\
-- \\
-- \\
7.2 \\
15.1 \\
15.2 \\
\end{array}$ & $\begin{array}{c}-- \\
-- \\
-- \\
12.1 \\
31.0 \\
36.9 \\
\end{array}$ & $\begin{array}{c}-- \\
-- \\
-- \\
58.3 \\
46.9 \\
42.1 \\
\end{array}$ & $\begin{array}{c}-- \\
-- \\
-- \\
29.6 \\
22.1 \\
21.1\end{array}$ & $\begin{array}{c}-- \\
-- \\
-- \\
\mathrm{SiCL} \\
\mathrm{L} \\
\mathrm{L} \\
\end{array}$ \\
\hline 6 & $\begin{array}{l}\text { Oi } \\
\text { M1 } \\
\text { M2 } \\
\text { M3 }\end{array}$ & $\begin{array}{c}0--42 \\
42--52 \\
52--72 \\
72--102\end{array}$ & $\begin{array}{l}-- \\
0.0 \\
0.0 \\
0.0\end{array}$ & $\begin{array}{l}-- \\
0.0 \\
0.1 \\
0.6\end{array}$ & $\begin{array}{l}-- \\
0.0 \\
1.0 \\
3.7\end{array}$ & $\begin{array}{l}-- \\
0.2 \\
2.1 \\
7.0\end{array}$ & $\begin{array}{l}-- \\
0.5 \\
3.7 \\
7.8\end{array}$ & $\begin{array}{c}-- \\
1.2 \\
7.2 \\
19.5\end{array}$ & $\begin{array}{c}-- \\
59.8 \\
64.7 \\
58.9\end{array}$ & $\begin{array}{c}-- \\
39.0 \\
28.1 \\
21.6\end{array}$ & $\begin{array}{c}-- \\
\text { SiCL } \\
\text { SiCL } \\
\text { SiL }\end{array}$ \\
\hline \multicolumn{12}{|c|}{ Iron Pond } \\
\hline 1 & $\begin{array}{l}\text { Oi } \\
\text { Oe } \\
\text { M1 } \\
\text { M2 } \\
\text { M3 } \\
\end{array}$ & $\begin{array}{c}0--7 \\
7--9 \\
9--19 \\
19--39 \\
39--69 \\
\end{array}$ & $\begin{array}{c}-- \\
-- \\
0 \\
5.9 \\
4.2 \\
\end{array}$ & $\begin{array}{c}-- \\
-- \\
0 \\
6.3 \\
5.1 \\
\end{array}$ & $\begin{array}{c}-- \\
-- \\
0 \\
13.3 \\
11.7 \\
\end{array}$ & $\begin{array}{c}-- \\
-- \\
0 \\
14.7 \\
11.6 \\
\end{array}$ & $\begin{array}{l}-- \\
-- \\
0.5 \\
9.7 \\
7.0 \\
\end{array}$ & $\begin{array}{c}-- \\
-- \\
1.0 \\
50.2 \\
39.7 \\
\end{array}$ & $\begin{array}{c}-- \\
-- \\
92.2 \\
36.0 \\
39.5 \\
\end{array}$ & $\begin{array}{c}-- \\
-- \\
6.7 \\
13.8 \\
20.8 \\
\end{array}$ & $\begin{array}{l}-- \\
-- \\
\mathrm{Si} \\
\mathrm{L} \\
\mathrm{L}\end{array}$ \\
\hline 2 & $\begin{array}{l}\text { Oi } \\
\text { M1 } \\
\text { M2 } \\
\text { M3 } \\
\text { M4 } \\
\end{array}$ & $\begin{array}{c}0--23 \\
23--45 \\
45-55 \\
55-75 \\
75--105 \\
\end{array}$ & $\begin{array}{c}0.0 \\
1.1 \\
17.0 \\
17.7 \\
2.1 \\
\end{array}$ & $\begin{array}{c}0.0 \\
1.5 \\
13.1 \\
13.0 \\
2.0 \\
\end{array}$ & $\begin{array}{c}0.0 \\
4.2 \\
18.9 \\
17.9 \\
3.6 \\
\end{array}$ & $\begin{array}{c}0.3 \\
8.0 \\
12.9 \\
12.9 \\
5.9 \\
\end{array}$ & $\begin{array}{l}0.3 \\
9.1 \\
4.6 \\
4.6 \\
8.6 \\
\end{array}$ & $\begin{array}{c}0.5 \\
25.1 \\
66.3 \\
66.0 \\
22.2 \\
\end{array}$ & $\begin{array}{l}93.3 \\
68.8 \\
21.2 \\
20.3 \\
46.5 \\
\end{array}$ & $\begin{array}{c}6.1 \\
6.1 \\
12.5 \\
13.7 \\
31.3 \\
\end{array}$ & $\begin{array}{l}\mathrm{Si} \\
\mathrm{SiL} \\
\mathrm{SL} \\
\mathrm{SL} \\
\mathrm{CL}\end{array}$ \\
\hline 3 & $\begin{array}{l}\text { M/Oi } \\
\text { M1 } \\
\text { M2 } \\
\text { M3 } \\
\end{array}$ & $\begin{array}{c}0--22 \\
22--32 \\
32--52 \\
52--82 \\
\end{array}$ & $\begin{array}{l}1.7 \\
0.2 \\
2.2 \\
0.8 \\
\end{array}$ & $\begin{array}{l}7.1 \\
0.4 \\
1.8 \\
0.6 \\
\end{array}$ & $\begin{array}{l}9.3 \\
2.7 \\
3.5 \\
0.8 \\
\end{array}$ & $\begin{array}{c}15.1 \\
11.6 \\
4.6 \\
1.1 \\
\end{array}$ & $\begin{array}{c}18.2 \\
11.5 \\
5.7 \\
2.7 \\
\end{array}$ & $\begin{array}{c}52.3 \\
27.4 \\
17.9 \\
6.1 \\
\end{array}$ & $\begin{array}{l}45.1 \\
47.7 \\
54.4 \\
61.8 \\
\end{array}$ & $\begin{array}{c}2.6 \\
24.9 \\
27.7 \\
32.1 \\
\end{array}$ & $\begin{array}{c}\mathrm{SL} \\
\mathrm{L} \\
\mathrm{SiCL} \\
\mathrm{SiCL} \\
\end{array}$ \\
\hline 4 & $\begin{array}{l}\text { Oi } \\
\text { M1 } \\
\text { M2 } \\
\text { M3 } \\
\text { M4 } \\
\end{array}$ & $\begin{array}{c}0--21 \\
21--32 \\
32--42 \\
42--62 \\
62--92 \\
\end{array}$ & $\begin{array}{l}-- \\
0.2 \\
2.1 \\
0.1 \\
1.5 \\
\end{array}$ & $\begin{array}{l}-- \\
0.8 \\
2.1 \\
0.2 \\
2.0 \\
\end{array}$ & $\begin{array}{l}-- \\
0.5 \\
3.6 \\
0.5 \\
4.8 \\
\end{array}$ & $\begin{array}{c}-- \\
1.2 \\
8.9 \\
0.9 \\
20.1 \\
\end{array}$ & $\begin{array}{c}-- \\
1.7 \\
12.1 \\
2.2 \\
21.3 \\
\end{array}$ & $\begin{array}{c}-- \\
4.9 \\
29.0 \\
4.1 \\
50.1 \\
\end{array}$ & $\begin{array}{c}-- \\
64.2 \\
47.6 \\
66.4 \\
35.0 \\
\end{array}$ & $\begin{array}{c}-- \\
30.9 \\
23.4 \\
29.5 \\
14.9 \\
\end{array}$ & $\begin{array}{c}-- \\
\mathrm{SiCL} \\
\mathrm{L} \\
\mathrm{SiCL} \\
\mathrm{L}\end{array}$ \\
\hline 5 & $\begin{array}{l}\text { Oi } \\
\text { M1 } \\
\text { M2 } \\
\text { M3 } \\
\text { M4 } \\
\text { M5 } \\
\text { M6 } \\
\end{array}$ & $\begin{array}{c}0--18 \\
18--31 \\
31--50 \\
50--64 \\
64--74 \\
74--94 \\
94--124\end{array}$ & $\begin{array}{l}-- \\
0.0 \\
0.0 \\
0.1 \\
1.0 \\
3.7 \\
3.8\end{array}$ & $\begin{array}{l}-- \\
0.0 \\
0.1 \\
0.2 \\
1.2 \\
2.6 \\
3.7 \\
\end{array}$ & $\begin{array}{l}-- \\
0.0 \\
0.1 \\
1.6 \\
1.5 \\
4.8 \\
4.8 \\
\end{array}$ & $\begin{array}{l}-- \\
0.7 \\
0.7 \\
8.1 \\
1.6 \\
5.0 \\
5.5\end{array}$ & $\begin{array}{c}-- \\
1.6 \\
2.2 \\
10.8 \\
2.8 \\
3.6 \\
5.6 \\
\end{array}$ & $\begin{array}{c}-- \\
2.9 \\
3.4 \\
21.1 \\
8.3 \\
19.5 \\
23.6\end{array}$ & $\begin{array}{c}-- \\
63.3 \\
60.2 \\
52.7 \\
54.8 \\
49.4 \\
55.5 \\
\end{array}$ & \begin{tabular}{c|}
- \\
33.8 \\
36.4 \\
26.2 \\
36.9 \\
31.1 \\
20.8 \\
\end{tabular} & $\begin{array}{c}\text { SiL } \\
\text { SiCL } \\
\text { SiCL } \\
\text { SiL }\end{array}$ \\
\hline
\end{tabular}




\begin{tabular}{|c|c|c|c|c|c|c|c|c|c|c|c|}
\hline \multirow[t]{2}{*}{$\begin{array}{l}\text { Transect- } \\
\text { Stop }\end{array}$} & \multirow[t]{2}{*}{ Soil Type } & \multirow{2}{*}{$\begin{array}{c}\text { Sample } \\
\text { Depth } \\
\text { cm }\end{array}$} & $\begin{array}{l}\text { Very Coarse } \\
\text { Sand }\end{array}$ & $\begin{array}{c}\text { Coarse } \\
\text { Sand }\end{array}$ & $\begin{array}{l}\text { Medium } \\
\text { Sand }\end{array}$ & $\begin{array}{l}\text { Fine } \\
\text { Sand }\end{array}$ & $\begin{array}{l}\text { Very Fine } \\
\text { Sand }\end{array}$ & Sand & Silt & Clay & Class* \\
\hline & & & \multicolumn{8}{|c|}{$\%$} & \\
\hline \multicolumn{12}{|c|}{ Railroad Grade } \\
\hline $1--1$ & $\begin{array}{l}\text { Oi } \\
\text { Oe } \\
\text { Oa } \\
\text { M1 } \\
\text { M2 }\end{array}$ & $\begin{array}{c}0--18 \\
18--25 \\
25--35 \\
35--55 \\
55--85\end{array}$ & $\begin{array}{l}-- \\
-- \\
-- \\
0.8 \\
1.1\end{array}$ & $\begin{array}{l}-- \\
-- \\
-- \\
1.5 \\
1.9\end{array}$ & $\begin{array}{l}-- \\
-- \\
-- \\
4.8 \\
5.5\end{array}$ & $\begin{array}{l}-- \\
-- \\
-- \\
5.4 \\
6.2\end{array}$ & $\begin{array}{l}-- \\
-- \\
-- \\
3.8 \\
3.9\end{array}$ & $\begin{array}{c}-- \\
-- \\
-- \\
16.3 \\
18.6\end{array}$ & $\begin{array}{c}-- \\
-- \\
-- \\
54.2 \\
48.6\end{array}$ & $\begin{array}{c}-- \\
-- \\
-- \\
29.6 \\
32.8\end{array}$ & $\begin{array}{c}-- \\
-- \\
-- \\
\mathrm{SiCL} \\
\mathrm{SiCL}\end{array}$ \\
\hline $1--2$ & $\begin{array}{c}\mathrm{Oi} \\
\mathrm{Oe} \\
\mathrm{Oa} 1 \\
\mathrm{Oa} 2 \\
\mathrm{M} 1 \\
\mathrm{M} 2 \\
\end{array}$ & $\begin{array}{c}0--33 \\
33--40 \\
40--45 \\
45-55 \\
55--75 \\
75--82 \\
\end{array}$ & $\begin{array}{c}-- \\
-- \\
-- \\
-- \\
0.6 \\
0.0\end{array}$ & $\begin{array}{l}-- \\
-- \\
-- \\
-- \\
0.7 \\
0.1\end{array}$ & $\begin{array}{l}-- \\
-- \\
-- \\
-- \\
2.6 \\
0.2\end{array}$ & $\begin{array}{l}-- \\
-- \\
-- \\
-- \\
3.0 \\
0.3 \\
\end{array}$ & $\begin{array}{l}-- \\
-- \\
-- \\
-- \\
4.0 \\
0.9\end{array}$ & $\begin{array}{c}-- \\
-- \\
-- \\
-- \\
11.0 \\
1.5 \\
\end{array}$ & $\begin{array}{c}-- \\
-- \\
-- \\
-- \\
57.7 \\
63.0 \\
\end{array}$ & $\begin{array}{c}-- \\
-- \\
-- \\
-- \\
31.3 \\
35.5 \\
\end{array}$ & $\begin{array}{c}-- \\
-- \\
-- \\
-- \\
\mathrm{SiCL} \\
\mathrm{SiCL}\end{array}$ \\
\hline $1--3$ & $\begin{array}{l}\text { Oi } \\
\text { Oe } \\
\text { M1 } \\
\text { M2 } \\
\text { Oa } \\
\text { M3 }\end{array}$ & $\begin{array}{c}0--13 \\
13--23 \\
23--33 \\
33--53 \\
42--47 \\
53--83\end{array}$ & $\begin{array}{c}-- \\
-- \\
0.0 \\
0.0 \\
-- \\
0.0\end{array}$ & $\begin{array}{l}-- \\
-- \\
0.0 \\
0.0 \\
-- \\
0.0\end{array}$ & $\begin{array}{c}-- \\
-- \\
0.1 \\
0.2 \\
-- \\
0.5\end{array}$ & $\begin{array}{c}-- \\
-- \\
0.1 \\
0.2 \\
-- \\
0.7 \\
\end{array}$ & $\begin{array}{c}-- \\
-- \\
0.2 \\
0.6 \\
-- \\
1.2\end{array}$ & $\begin{array}{c}-- \\
-- \\
0.5 \\
1.4 \\
-- \\
2.6\end{array}$ & $\begin{array}{c}-- \\
-- \\
61.7 \\
63.9 \\
-- \\
55.9\end{array}$ & $\begin{array}{c}-- \\
-- \\
37.8 \\
34.7 \\
-- \\
41.5 \\
\end{array}$ & $\begin{array}{c}-- \\
-- \\
\mathrm{SiCL} \\
\mathrm{SiCL} \\
-- \\
\mathrm{SiC}\end{array}$ \\
\hline $1--4$ & $\begin{array}{l}\text { Oi } \\
\text { Oe } \\
\text { M1 } \\
\text { M2 } \\
\text { M3 } \\
\text { M4 } \\
\end{array}$ & $\begin{array}{c}0--13 \\
13--17 \\
17--27 \\
27--47 \\
47--77 \\
40--50 \\
\end{array}$ & $\begin{array}{l}-- \\
-- \\
1.2 \\
0.0 \\
0.1 \\
0.0\end{array}$ & $\begin{array}{l}-- \\
-- \\
1.2 \\
0.0 \\
0.0 \\
0.0\end{array}$ & $\begin{array}{c}-- \\
-- \\
3.2 \\
0.0 \\
0.7 \\
0.0\end{array}$ & $\begin{array}{l}-- \\
-- \\
3.5 \\
0.1 \\
2.3 \\
0.0 \\
\end{array}$ & $\begin{array}{l}-- \\
-- \\
4.3 \\
0.4 \\
4.2 \\
0.0\end{array}$ & $\begin{array}{c}-- \\
-- \\
13.7 \\
0.6 \\
7.7 \\
0.2 \\
\end{array}$ & $\begin{array}{c}-- \\
-- \\
55.5 \\
64.7 \\
56.6 \\
89.7 \\
\end{array}$ & $\begin{array}{c}-- \\
-- \\
30.8 \\
34.7 \\
35.7 \\
10.1 \\
\end{array}$ & $\begin{array}{c}-- \\
-- \\
\mathrm{SiCL} \\
\mathrm{SiCL} \\
\mathrm{SiCL} \\
\mathrm{Si} \\
\end{array}$ \\
\hline $2--1$ & $\begin{array}{l}\text { Oi } \\
\text { Oe } \\
\text { M1 } \\
\text { M2 } \\
\text { M3 } \\
\text { M4 } \\
\text { M5 } \\
\text { Oe } \\
\end{array}$ & $\begin{array}{c}0--7 \\
7--18 \\
18--28 \\
28--38 \\
38--58 \\
58--88 \\
88--124 \\
66--82\end{array}$ & $\begin{array}{l}-- \\
-- \\
0.0 \\
0.1 \\
0.0 \\
0.1 \\
0.3 \\
--\end{array}$ & $\begin{array}{l}-- \\
-- \\
0.1 \\
0.3 \\
0.0 \\
1.4 \\
1.8 \\
--\end{array}$ & $\begin{array}{l}-- \\
-- \\
0.3 \\
0.8 \\
0.6 \\
6.5 \\
8.0 \\
--\end{array}$ & $\begin{array}{c}-- \\
-- \\
0.4 \\
4.1 \\
3.8 \\
8.2 \\
8.4 \\
--\end{array}$ & $\begin{array}{c}-- \\
-- \\
1.7 \\
15.7 \\
16.9 \\
6.5 \\
3.7 \\
--\end{array}$ & $\begin{array}{c}-- \\
-- \\
2.8 \\
21.4 \\
21.3 \\
23.1 \\
22.2 \\
--\end{array}$ & $\begin{array}{c}-- \\
-- \\
62.1 \\
63.0 \\
67.5 \\
59.2 \\
53.5 \\
--\end{array}$ & $\begin{array}{c}-- \\
-- \\
35.1 \\
15.7 \\
11.2 \\
17.8 \\
24.3 \\
--\end{array}$ & $\begin{array}{c}-- \\
-- \\
\text { SiCL } \\
\text { SiL } \\
\text { SiL } \\
\text { SiL } \\
\text { L } \\
--\end{array}$ \\
\hline $2--2$ & $\begin{array}{l}\text { Oi } \\
\text { Oe } \\
\text { Oa } \\
\text { Oa } \\
\text { M1 } \\
\text { M2 } \\
\text { M3 }\end{array}$ & $\begin{array}{c}0--9 \\
9--16 \\
16--24 \\
24--34 \\
34--54 \\
54--84 \\
84--124 \\
\end{array}$ & $\begin{array}{c}-- \\
-- \\
-- \\
-- \\
0.5 \\
0.4 \\
4.4\end{array}$ & $\begin{array}{l}-- \\
-- \\
-- \\
-- \\
0.0 \\
2.1 \\
8.8\end{array}$ & $\begin{array}{c}-- \\
-- \\
-- \\
-- \\
0.5 \\
6.6 \\
23.5 \\
\end{array}$ & $\begin{array}{c}-- \\
-- \\
-- \\
-- \\
1.3 \\
5.6 \\
18.8 \\
\end{array}$ & $\begin{array}{l}-- \\
-- \\
-- \\
-- \\
4.0 \\
2.2 \\
6.3 \\
\end{array}$ & $\begin{array}{c}-- \\
-- \\
-- \\
-- \\
6.2 \\
17.3 \\
61.6 \\
\end{array}$ & $\begin{array}{c}-- \\
-- \\
-- \\
-- \\
86.1 \\
46.4 \\
25.6 \\
\end{array}$ & $\begin{array}{c}-- \\
-- \\
-- \\
-- \\
7.6 \\
36.3 \\
12.8 \\
\end{array}$ & $\begin{array}{c}-- \\
-- \\
-- \\
-- \\
\mathrm{Si} \\
\mathrm{SiCL} \\
\mathrm{SL}\end{array}$ \\
\hline $2--3$ & $\begin{array}{l}\mathrm{Oi} \\
\mathrm{Oe} \\
\mathrm{Oa} \\
\mathrm{M} 1 \\
\mathrm{M} 2\end{array}$ & $\begin{array}{c}0--20 \\
20--28 \\
28--38 \\
38--58 \\
58--71\end{array}$ & $\begin{array}{l}-- \\
-- \\
-- \\
0.0 \\
0.0\end{array}$ & $\begin{array}{l}-- \\
-- \\
-- \\
0.0 \\
0.1\end{array}$ & $\begin{array}{l}-- \\
-- \\
-- \\
0.9 \\
1.4\end{array}$ & $\begin{array}{l}-- \\
-- \\
-- \\
1.3 \\
2.2\end{array}$ & $\begin{array}{l}-- \\
-- \\
-- \\
1.7 \\
2.6\end{array}$ & $\begin{array}{c}-- \\
-- \\
-- \\
4.4 \\
6.7\end{array}$ & $\begin{array}{c}-- \\
-- \\
-- \\
53.8 \\
54.7\end{array}$ & $\begin{array}{c}-- \\
-- \\
-- \\
41.8 \\
38.7\end{array}$ & $\begin{array}{c}-- \\
-- \\
-- \\
\mathrm{SiC} \\
\mathrm{SiCL}\end{array}$ \\
\hline
\end{tabular}




\begin{tabular}{|c|c|c|c|c|c|c|c|c|c|c|c|}
\hline \multirow[t]{2}{*}{ Stop } & \multirow[t]{2}{*}{ Soil Type } & \multirow{2}{*}{$\begin{array}{c}\text { Sample } \\
\text { Depth } \\
\mathrm{cm}\end{array}$} & $\begin{array}{l}\text { Very Coarse } \\
\text { Sand }\end{array}$ & $\begin{array}{l}\text { Coarse } \\
\text { Sand }\end{array}$ & $\begin{array}{l}\text { Medium } \\
\text { Sand }\end{array}$ & $\begin{array}{l}\text { Fine } \\
\text { Sand }\end{array}$ & $\begin{array}{l}\text { Very Fine } \\
\text { Sand }\end{array}$ & Sand & Silt & Clay & \multirow[t]{2}{*}{ Class $^{*}$} \\
\hline & & & \multicolumn{8}{|c|}{$\%$} & \\
\hline \multicolumn{12}{|c|}{ Alder Thicket } \\
\hline \multirow[t]{6}{*}{1} & $\mathrm{Oe}$ & $0--3$ & -- & -- & -- & -- & -- & -- & _- & -- & _- \\
\hline & Oa1 & 3--9 & -- & -- & -- & -- & -- & -- & -- & -- & -- \\
\hline & Oa2 & $9--19$ & -- & -- & -- & -- & -- & -- & -- & -- & -- \\
\hline & M1 & $19-39$ & 0.0 & 0.0 & 0.2 & 0.2 & 1.1 & 1.8 & 59.3 & 38.9 & $\mathrm{SiCL}$ \\
\hline & M2 & $39--69$ & 0.0 & 0.0 & 0.6 & 1.0 & 2.0 & 3.7 & 59.6 & 36.7 & $\mathrm{SiCL}$ \\
\hline & M3 & 69--109 & 0.8 & 3.3 & 9.3 & 10.7 & 9.0 & 33.8 & 45.6 & 20.6 & $\mathrm{~L}$ \\
\hline \multirow[t]{6}{*}{3} & Oe & $0--3$ & -- & -- & -- & -- & -- & -- & -- & -- & -- \\
\hline & $\mathrm{Oa}$ & $3--25$ & -- & -- & -- & -- & -- & -- & -- & -- & -- \\
\hline & $\mathrm{Oa}$ & 25--35 & -- & -- & -- & -- & -- & -- & -- & -- & -- \\
\hline & M1 & $35--55$ & 0.0 & 0.0 & 0.1 & 0.6 & 2.6 & 3.6 & 63.9 & 32.6 & $\mathrm{SiCL}$ \\
\hline & M2 & $55-85$ & 0.0 & 0.0 & 0.4 & 0.7 & 2.2 & 3.4 & 61.4 & 35.2 & $\mathrm{SiCL}$ \\
\hline & M3 & $85--125$ & 0.1 & 0.6 & 4.2 & 4.0 & 4.6 & 14.0 & 59.6 & 26.4 & $\mathrm{SiL}$ \\
\hline \multicolumn{12}{|c|}{ Forested Wetland } \\
\hline \multirow[t]{6}{*}{1} & Oi & $0--7$ & -- & -- & -- & -- & -- & -- & -- & -- & -- \\
\hline & M1 & $7--11$ & 0.0 & 0.0 & 0.3 & 1.6 & 1.5 & 3.7 & 61.2 & 35.1 & $\mathrm{SiCL}$ \\
\hline & M2 & $11--21$ & 0.6 & 1.4 & 4.0 & 7.6 & 5.9 & 19.8 & 51.6 & 28.5 & $\mathrm{SiCL}$ \\
\hline & M3 & 21--41 & 1.8 & 2.2 & 5.9 & 9.8 & 7.2 & 27.3 & 47.3 & 25.4 & $\mathrm{~L}$ \\
\hline & M4 & $41--71$ & 2.1 & 3.5 & 9.4 & 23.8 & 8.0 & 36.2 & 47.0 & 16.7 & L \\
\hline & M5 & $71--111$ & 3.7 & 5.4 & 11.0 & 14.0 & 6.9 & 41.2 & 42.7 & 16.2 & L \\
\hline \multirow[t]{6}{*}{2} & $\mathrm{Oe}$ & $0--4$ & .- & .- & .- & .- & .- & .- & .- & .- & .- \\
\hline & $\mathrm{Oa}$ & $4--14$ & -- & -- & -- & -- & -- & -- & -- & -- & -- \\
\hline & M1 & 14--34 & 0.5 & 2.6 & 11.3 & 16.1 & 7.1 & 37.6 & 45.3 & 17.1 & L \\
\hline & M2 & 34--64 & 1.1 & 4.2 & 12.6 & 16.4 & 6.3 & 40.8 & 36.4 & 22.8 & $\bar{L}$ \\
\hline & M3 & 64--104 & 1.3 & 5.9 & 15.0 & 16.7 & 7.8 & 47.1 & 32.9 & 20.0 & L \\
\hline & M4 & 104--150 & 2.8 & 10.9 & 16.9 & 18.7 & 7.9 & 53.6 & 31.6 & 14.8 & SL \\
\hline \multicolumn{12}{|c|}{ Scrub Shrub } \\
\hline \multirow[t]{5}{*}{1} & $\mathrm{Oa}$ & $0--4$ & -- & -- & -- & -- & -- & -- & -- & -- & -- \\
\hline & M1 & $4--14$ & 0.3 & 0.9 & 2.7 & 5.0 & 6.7 & 15.6 & 65.5 & 18.9 & SiL \\
\hline & M2 & 14--34 & 0.9 & 1.0 & 2.3 & 4.6 & 6.0 & 15.3 & 59.6 & 25.1 & SiL \\
\hline & M3 & 34--64 & 2.0 & 4.7 & 9.9 & 10.5 & 7.1 & 34.3 & 43.7 & 22.0 & L \\
\hline & M4 & 64--104 & 2.6 & 4.7 & 9.5 & 8.1 & 5.2 & 30.0 & 46.6 & 23.4 & $\mathrm{~L}$ \\
\hline \multirow[t]{5}{*}{2} & $\mathrm{Oa}$ & $0--9$ & -- & -- & -- & -- & -- & _- & _- & -- & -- \\
\hline & M1 & 9--19 & 0.0 & 0.5 & 1.6 & 3.8 & 5.3 & 11.4 & 65.6 & 23.0 & SiL \\
\hline & M2 & 19--39 & 0.4 & 1.7 & 4.4 & 8.8 & 8.7 & 24.2 & 47.6 & 28.2 & $\mathrm{CL}$ \\
\hline & M3 & 39--69 & 1.4 & 4.9 & 10.4 & 9.0 & 7.3 & 33.4 & 38.6 & 28.0 & $\mathrm{CL}$ \\
\hline & M4 & 69--109 & 2.0 & 4.5 & 8.4 & 9.3 & 9.1 & 33.7 & 46.9 & 19.3 & L \\
\hline
\end{tabular}




\begin{tabular}{|c|c|c|c|c|c|c|c|c|c|c|c|}
\hline \multirow[t]{2}{*}{$\begin{array}{c}\text { Transect- } \\
\text { Stop }\end{array}$} & \multirow[t]{2}{*}{ Soil Type } & \multirow{2}{*}{$\begin{array}{c}\text { Sample } \\
\text { Depth } \\
\mathrm{cm}\end{array}$} & $\begin{array}{c}\text { Very Coarse } \\
\text { Sand }\end{array}$ & $\begin{array}{l}\text { Coarse } \\
\text { Sand }\end{array}$ & $\begin{array}{l}\text { Medium } \\
\text { Sand }\end{array}$ & $\begin{array}{l}\text { Fine } \\
\text { Sand }\end{array}$ & $\begin{array}{l}\text { Very Fine } \\
\text { Sand }\end{array}$ & Sand & Silt & Clay & \multirow[t]{2}{*}{ Class* } \\
\hline & & & \multicolumn{8}{|c|}{$\%$} & \\
\hline \multicolumn{12}{|c|}{ Fen-Marsh } \\
\hline $1-2$ & $\begin{array}{l}\text { Oi } \\
\text { Oe } \\
\text { Oa } \\
\text { Oa } \\
\text { Oa } \\
\text { M1 } \\
\text { M2 } \\
\text { M3 } \\
\end{array}$ & $\begin{array}{c}0--8 \\
8--16 \\
16--41 \\
41--48 \\
48--58 \\
58--78 \\
78--108 \\
108--148 \\
\end{array}$ & $\begin{array}{l}-- \\
-- \\
-- \\
-- \\
-- \\
0.0 \\
0.0 \\
0.0\end{array}$ & $\begin{array}{l}-- \\
-- \\
-- \\
-- \\
-- \\
0.0 \\
1.4 \\
0.0\end{array}$ & $\begin{array}{c}-- \\
-- \\
-- \\
-- \\
-- \\
0.6 \\
30.6 \\
6.8 \\
\end{array}$ & $\begin{array}{c}-- \\
-- \\
-- \\
-- \\
-- \\
7.9 \\
36.1 \\
23.7\end{array}$ & $\begin{array}{c}-- \\
-- \\
-- \\
-- \\
-- \\
18.3 \\
10.1 \\
19.6 \\
\end{array}$ & $\begin{array}{c}-- \\
-- \\
-- \\
-- \\
-- \\
27.1 \\
78.5 \\
50.7\end{array}$ & $\begin{array}{c}-- \\
-- \\
-- \\
-- \\
-- \\
59.3 \\
16.9 \\
39.7 \\
\end{array}$ & $\begin{array}{c}-- \\
-- \\
-- \\
-- \\
-- \\
13.7 \\
4.6 \\
9.7\end{array}$ & $\begin{array}{c}-- \\
-- \\
-- \\
-- \\
-- \\
\text { SiL } \\
\text { SL } \\
\text { L }\end{array}$ \\
\hline $2-1$ & $\begin{array}{l}\mathrm{Oi} \\
\mathrm{Oe} \\
\mathrm{Oa} \\
\mathrm{Oa} \\
\mathrm{Oa}\end{array}$ & $\begin{array}{c}0--4 \\
4--42 \\
42--52 \\
52--72 \\
72--102\end{array}$ & $\begin{array}{l}-- \\
-- \\
-- \\
-- \\
--\end{array}$ & $\begin{array}{l}-- \\
-- \\
-- \\
-- \\
--\end{array}$ & $\begin{array}{l}-- \\
-- \\
-- \\
-- \\
--\end{array}$ & $\begin{array}{l}-- \\
-- \\
-- \\
-- \\
--\end{array}$ & $\begin{array}{l}-- \\
-- \\
-- \\
-- \\
--\end{array}$ & $\begin{array}{l}-- \\
-- \\
-- \\
-- \\
--\end{array}$ & $\begin{array}{l}-- \\
-- \\
-- \\
-- \\
--\end{array}$ & $\begin{array}{l}-- \\
-- \\
-- \\
-- \\
--\end{array}$ & $\begin{array}{l}-- \\
-- \\
-- \\
-- \\
--\end{array}$ \\
\hline $2-3$ & $\begin{array}{l}\mathrm{Oe} \\
\mathrm{Oa} \\
\mathrm{Oa} \\
\mathrm{Oa} \\
\mathrm{Oa} \\
\mathrm{Oa}\end{array}$ & $\begin{array}{c}0--21 \\
21-31 \\
31-41 \\
41-61 \\
61-91 \\
91-120+ \\
\end{array}$ & $\begin{array}{l}-- \\
-- \\
-- \\
-- \\
-- \\
--\end{array}$ & $\begin{array}{l}-- \\
-- \\
-- \\
-- \\
-- \\
--\end{array}$ & $\begin{array}{l}-- \\
-- \\
-- \\
-- \\
-- \\
--\end{array}$ & $\begin{array}{l}-- \\
-- \\
-- \\
-- \\
-- \\
--\end{array}$ & $\begin{array}{l}-- \\
-- \\
-- \\
-- \\
-- \\
--\end{array}$ & $\begin{array}{l}-- \\
-- \\
-- \\
- \\
-- \\
--\end{array}$ & $\begin{array}{l}-- \\
-- \\
-- \\
-- \\
-- \\
--\end{array}$ & $\begin{array}{l}-- \\
-- \\
-- \\
-- \\
-- \\
--\end{array}$ & $\begin{array}{l}-- \\
-- \\
-- \\
-- \\
-- \\
--\end{array}$ \\
\hline $2-4$ & $\begin{array}{l}\mathrm{Oi} \\
\mathrm{Oe} \\
\mathrm{Oa} \\
\mathrm{Oa} \\
\mathrm{Oa} \\
\mathrm{Oa} \\
\mathrm{M} 1\end{array}$ & $\begin{array}{c}0--23 \\
23--33 \\
33--43 \\
43--53 \\
53--73 \\
73--103 \\
103--143\end{array}$ & $\begin{array}{l}-- \\
-- \\
-- \\
-- \\
-- \\
-- \\
0.0\end{array}$ & $\begin{array}{l}-- \\
-- \\
-- \\
-- \\
-- \\
-- \\
0.5\end{array}$ & $\begin{array}{l}-- \\
-- \\
-- \\
-- \\
-- \\
-- \\
2.3\end{array}$ & $\begin{array}{l}-- \\
-- \\
-- \\
-- \\
-- \\
-- \\
3.3\end{array}$ & $\begin{array}{l}-- \\
-- \\
-- \\
-- \\
-- \\
-- \\
2.8\end{array}$ & $\begin{array}{l}-- \\
-- \\
-- \\
-- \\
-- \\
-- \\
9.3\end{array}$ & $\begin{array}{l}-- \\
-- \\
-- \\
-- \\
-- \\
-- \\
47.1\end{array}$ & $\begin{array}{c}-- \\
-- \\
-- \\
-- \\
-- \\
-- \\
43.6\end{array}$ & $\begin{array}{c}-- \\
-- \\
-- \\
-- \\
-- \\
-- \\
\text { SiCL }\end{array}$ \\
\hline
\end{tabular}

*-CL=Cay Loam, L=Loam, Si=Silt, SiC=Silty Clay, SiCL=Silty Clay Loam, SiL=Silt Loam, and SL=Sandy Loam 
Appendix C

Soil Chemical Properties 
Table 9. Soil pH, Electrical conductivity (Ec), total iron (Fe), extractable aluminum (Al), total carbon (C), and total nitrogen (N) for soils in all wetlands

\begin{tabular}{|c|c|c|c|c|c|c|c|c|}
\hline \multirow[t]{2}{*}{ Stop } & \multirow[t]{2}{*}{ Soil Type } & \multirow{2}{*}{$\begin{array}{c}\text { Sample Depth } \\
\mathrm{cm}\end{array}$} & \multirow[t]{2}{*}{$\mathrm{pH}$} & Ec & $\mathrm{Fe}$ & $\mathrm{Al}$ & C & $\mathrm{N}$ \\
\hline & & & & $\mathrm{dS} \mathrm{m}^{-1}$ & $u_{\mathrm{mol} \mathrm{g}} \mathrm{g}^{-1}$ & $\mathrm{cmolc} \mathrm{kg}^{-1}$ & \multicolumn{2}{|c|}{$\%$} \\
\hline \multicolumn{9}{|c|}{ Narrow Wetland } \\
\hline 2 & $\begin{array}{l}\mathrm{Oi} \\
\mathrm{M} 1 \\
\mathrm{M} 2 \\
\mathrm{M} 3 \\
\end{array}$ & $\begin{array}{c}0-5 \\
5--15 \\
15--35 \\
35--65 \\
\end{array}$ & $\begin{array}{l}4.1 \\
4.5 \\
4.5 \\
4.6\end{array}$ & $\begin{array}{l}0.17 \\
0.05 \\
0.08 \\
0.08 \\
\end{array}$ & $\begin{array}{c}313.2 \\
217.2 \\
46.3 \\
63.6 \\
\end{array}$ & $\begin{array}{l}2.5 \\
6.8 \\
5.7 \\
3.6 \\
\end{array}$ & $\begin{array}{c}16.5 \\
5.1 \\
5.9 \\
5.5\end{array}$ & $\begin{array}{l}0.5 \\
0.1 \\
0.2 \\
0.1 \\
\end{array}$ \\
\hline 4 & $\begin{array}{l}\mathrm{Oi} \\
\mathrm{Oe} \\
\mathrm{Oe} \\
\mathrm{M} 1 \\
\mathrm{M} 2 \\
\mathrm{M} 3 \\
\end{array}$ & $\begin{array}{c}0--6 \\
6--15 \\
15--23 \\
23--33 \\
33--53 \\
53--83 \\
\end{array}$ & $\begin{array}{l}5.9 \\
5.3 \\
5.9 \\
5.5 \\
5.7 \\
6.1 \\
\end{array}$ & $\begin{array}{l}0.20 \\
0.23 \\
0.21 \\
0.28 \\
0.25 \\
0.26 \\
\end{array}$ & $\begin{array}{c}1220.3 \\
947.8 \\
603.2 \\
109.2 \\
54.1 \\
51.3 \\
\end{array}$ & $\begin{array}{l}\text { BDL* } \\
\text { BDL } \\
\text { BDL } \\
\text { BDL } \\
\text { BDL } \\
\text { BDL }\end{array}$ & $\begin{array}{c}26.8 \\
28.8 \\
28.4 \\
9.0 \\
5.1 \\
5.8 \\
\end{array}$ & $\begin{array}{l}0.4 \\
0.5 \\
0.8 \\
0.1 \\
0.1 \\
0.1 \\
\end{array}$ \\
\hline 6 & $\begin{array}{l}\text { Oi } \\
\text { M1 } \\
\text { M2 } \\
\text { M3 } \\
\end{array}$ & $\begin{array}{c}0--42 \\
42--52 \\
52--72 \\
72--102 \\
\end{array}$ & $\begin{array}{l}5.4 \\
4.8 \\
4.9 \\
5.1 \\
\end{array}$ & $\begin{array}{l}0.20 \\
0.25 \\
0.15 \\
0.15 \\
\end{array}$ & $\begin{array}{c}2979.7 \\
271.4 \\
215.1 \\
84.5 \\
\end{array}$ & $\begin{array}{l}0.2 \\
0.7 \\
1.1 \\
0.8\end{array}$ & $\begin{array}{c}29.0 \\
6.0 \\
8.0 \\
8.2 \\
\end{array}$ & $\begin{array}{l}0.4 \\
0.1 \\
0.2 \\
0.2 \\
\end{array}$ \\
\hline \multicolumn{9}{|c|}{ Iron Pond } \\
\hline 1 & $\begin{array}{l}\text { Oi } \\
\text { Oe } \\
\text { M1 } \\
\text { M2 } \\
\text { M3 } \\
\end{array}$ & $\begin{array}{c}0--7 \\
7--9 \\
9--19 \\
19--39 \\
39--69 \\
\end{array}$ & $\begin{array}{l}6.0 \\
6.0 \\
5.7 \\
4.8 \\
4.9 \\
\end{array}$ & $\begin{array}{l}0.11 \\
0.08 \\
0.10 \\
0.09 \\
0.11 \\
\end{array}$ & $\begin{array}{c}643.9 \\
1079.1 \\
932.0 \\
334.1 \\
417.0 \\
\end{array}$ & $\begin{array}{c}\text { BDL } \\
\text { BDL } \\
\text { BDL } \\
0.5 \\
0.2 \\
\end{array}$ & $\begin{array}{c}26.0 \\
13.2 \\
8.7 \\
1.5 \\
1.5 \\
\end{array}$ & $\begin{array}{c}0.3 \\
0.2 \\
0.1 \\
\text { BDL } \\
0.0 \\
\end{array}$ \\
\hline 2 & $\begin{array}{c}\text { Oi } \\
\text { M1 } \\
\text { M2 } \\
\text { M3 } \\
\text { M4 } \\
\end{array}$ & $\begin{array}{c}0--23 \\
23--45 \\
45-55 \\
55-75 \\
75--105 \\
\end{array}$ & $\begin{array}{l}5.0 \\
4.7 \\
4.7 \\
4.7 \\
4.5 \\
\end{array}$ & $\begin{array}{l}0.10 \\
0.25 \\
0.08 \\
0.06 \\
0.12 \\
\end{array}$ & $\begin{array}{l}871.0 \\
711.5 \\
694.2 \\
397.4 \\
499.0 \\
\end{array}$ & $\begin{array}{l}0.7 \\
0.4 \\
0.3 \\
0.5 \\
1.3 \\
\end{array}$ & $\begin{array}{c}12.2 \\
2.5 \\
0.8 \\
0.6 \\
1.4 \\
\end{array}$ & $\begin{array}{c}0.2 \\
0.0 \\
0.0 \\
\text { BDL } \\
0.0 \\
\end{array}$ \\
\hline 3 & $\begin{array}{l}\mathrm{M} / \mathrm{Oi} \\
\mathrm{M} 1 \\
\mathrm{M} 2 \\
\mathrm{M} 3 \\
\end{array}$ & $\begin{array}{c}0--22 \\
22--32 \\
32--52 \\
52--82 \\
\end{array}$ & $\begin{array}{l}3.4 \\
4.8 \\
4.5 \\
4.3 \\
\end{array}$ & $\begin{array}{l}0.34 \\
0.29 \\
0.11 \\
0.11 \\
\end{array}$ & $\begin{array}{c}3708.8 \\
315.0 \\
450.0 \\
437.9 \\
\end{array}$ & $\begin{array}{l}2.3 \\
1.1 \\
0.9 \\
1.3 \\
\end{array}$ & $\begin{array}{l}9.6 \\
2.1 \\
1.5 \\
2.0 \\
\end{array}$ & $\begin{array}{c}0.2 \\
0.0 \\
\mathrm{BDL} \\
0.0 \\
\end{array}$ \\
\hline 4 & $\begin{array}{c}\text { Oi } \\
\text { M1 } \\
\text { M2 } \\
\text { M3 } \\
\text { M4 } \\
\end{array}$ & $\begin{array}{c}0--21 \\
21--32 \\
32--42 \\
42--62 \\
62--92 \\
\end{array}$ & $\begin{array}{l}3.6 \\
4.9 \\
4.5 \\
4.0 \\
4.6 \\
\end{array}$ & $\begin{array}{l}0.16 \\
0.25 \\
0.09 \\
0.12 \\
0.05 \\
\end{array}$ & $\begin{array}{l}891.7 \\
559.6 \\
440.1 \\
461.6 \\
565.8 \\
\end{array}$ & $\begin{array}{c}10.9 \\
0.6 \\
1.4 \\
3.4 \\
0.8 \\
\end{array}$ & $\begin{array}{c}21.4 \\
7.1 \\
4.2 \\
1.4 \\
1.8 \\
\end{array}$ & $\begin{array}{c}0.3 \\
0.8 \\
0.0 \\
\text { BDL } \\
\text { BDL }\end{array}$ \\
\hline 5 & $\begin{array}{l}\text { Oi } \\
\text { M1 } \\
\text { M2 } \\
\text { M3 } \\
\text { M4 } \\
\text { M5 } \\
\text { M6 } \\
\end{array}$ & $\begin{array}{c}0--18 \\
18--31 \\
31--50 \\
50--64 \\
64--74 \\
74--94 \\
94--124\end{array}$ & $\begin{array}{l}3.2 \\
5.1 \\
5.1 \\
4.8 \\
4.2 \\
4.3 \\
4.4 \\
\end{array}$ & $\begin{array}{l}0.37 \\
0.21 \\
0.20 \\
0.13 \\
0.10 \\
0.05 \\
0.07 \\
\end{array}$ & $\begin{array}{c}1822.6 \\
1298.2 \\
482.2 \\
423.9 \\
534.4 \\
535.5 \\
472.7 \\
\end{array}$ & $\begin{array}{l}5.6 \\
0.2 \\
0.4 \\
0.8 \\
1.1 \\
1.4 \\
1.1 \\
\end{array}$ & $\begin{array}{c}14.3 \\
5.4 \\
3.2 \\
2.4 \\
1.4 \\
2.6 \\
4.3 \\
\end{array}$ & $\begin{array}{c}0.2 \\
1.1 \\
1.6 \\
0.0 \\
\text { BDL } \\
0.0 \\
0.0 \\
\end{array}$ \\
\hline
\end{tabular}




\begin{tabular}{|c|c|c|c|c|c|c|c|c|}
\hline \multirow[t]{2}{*}{$\begin{array}{l}\text { Transect-- } \\
\text { Stop }\end{array}$} & \multirow[t]{2}{*}{ Soil Type } & \multirow{2}{*}{$\begin{array}{c}\text { Sample Depth } \\
\mathrm{cm}\end{array}$} & \multirow[t]{2}{*}{$\mathrm{pH}$} & Ec & $\mathrm{Fe}$ & $\begin{array}{c}\text { Extractable } \\
\mathrm{Al}\end{array}$ & C & $N$ \\
\hline & & & & $d S m^{-1}$ & $u m o l g^{-1}$ & $\mathrm{cmol}_{\mathrm{C} \mathrm{kg}}{ }^{-1}$ & \multicolumn{2}{|c|}{$\%$} \\
\hline \multicolumn{9}{|c|}{ Railroad Grade } \\
\hline $1--1$ & $\begin{array}{l}\text { Oi } \\
\text { Oe } \\
\text { Oa } \\
\text { M1 } \\
\text { M2 }\end{array}$ & $\begin{array}{c}0--18 \\
18--25 \\
25--35 \\
35--55 \\
55--85\end{array}$ & $\begin{array}{l}3.9 \\
3.8 \\
3.9 \\
4.2 \\
4.3 \\
\end{array}$ & $\begin{array}{l}0.10 \\
0.12 \\
0.14 \\
0.08 \\
0.06\end{array}$ & $\begin{array}{c}75.9 \\
118.4 \\
63.2 \\
77.0 \\
125.3\end{array}$ & $\begin{array}{c}7.4 \\
8.6 \\
21.4 \\
10.1 \\
6.7\end{array}$ & $\begin{array}{c}40.0 \\
41.2 \\
23.9 \\
5.0 \\
1.6\end{array}$ & $\begin{array}{l}0.5 \\
0.7 \\
0.6 \\
0.1 \\
0.0\end{array}$ \\
\hline $1--2$ & $\begin{array}{c}\text { Oi } \\
\text { Oe } \\
\text { Oa1 } \\
\text { Oa2 } \\
\text { M1 } \\
\text { M2 } \\
\end{array}$ & $\begin{array}{c}0--33 \\
33--40 \\
40--45 \\
45-55 \\
55--75 \\
75--82 \\
\end{array}$ & $\begin{array}{l}4.0 \\
4.0 \\
4.1 \\
4.1 \\
4.1 \\
4.3 \\
\end{array}$ & $\begin{array}{l}0.15 \\
0.15 \\
0.08 \\
0.10 \\
0.12 \\
0.09 \\
\end{array}$ & $\begin{array}{c}58.0 \\
101.0 \\
224.7 \\
77.5 \\
140.0 \\
336.9 \\
\end{array}$ & $\begin{array}{c}22.1 \\
7.7 \\
6.3 \\
14.0 \\
8.0 \\
2.8 \\
\end{array}$ & $\begin{array}{c}38.7 \\
34.6 \\
34.8 \\
28.4 \\
6.0 \\
7.5 \\
\end{array}$ & $\begin{array}{l}0.6 \\
0.5 \\
0.9 \\
0.7 \\
0.1 \\
0.1\end{array}$ \\
\hline $1-3$ & $\begin{array}{l}\text { Oi } \\
\text { Oe } \\
\text { M1 } \\
\text { M2 } \\
\text { Oa } \\
\text { M3 } \\
\end{array}$ & $\begin{array}{c}0--13 \\
13--23 \\
23--33 \\
33--53 \\
42--47 \\
53--83 \\
\end{array}$ & $\begin{array}{l}4.7 \\
4.8 \\
4.2 \\
4.3 \\
4.4 \\
4.2 \\
\end{array}$ & $\begin{array}{l}0.05 \\
0.08 \\
0.11 \\
0.08 \\
0.08 \\
0.07 \\
\end{array}$ & $\begin{array}{c}1352.6 \\
285.9 \\
410.4 \\
532.6 \\
379.1 \\
600.5 \\
\end{array}$ & $\begin{array}{c}3.3 \\
5.6 \\
2.7 \\
6.1 \\
6.6 \\
10.5 \\
\end{array}$ & $\begin{array}{c}16.8 \\
20.8 \\
4.3 \\
8.6 \\
14.8 \\
6.9 \\
\end{array}$ & $\begin{array}{l}0.3 \\
0.6 \\
0.1 \\
0.2 \\
0.3 \\
0.1\end{array}$ \\
\hline $1--4$ & $\begin{array}{l}\text { Oi } \\
\text { Oe } \\
\text { M1 } \\
\text { M2 } \\
\text { M3 } \\
\text { M4 }\end{array}$ & $\begin{array}{c}0--13 \\
13--17 \\
17--27 \\
27--47 \\
47--77 \\
40--50\end{array}$ & $\begin{array}{l}4.9 \\
4.8 \\
3.9 \\
4.2 \\
4.3 \\
4.3\end{array}$ & $\begin{array}{l}0.23 \\
0.15 \\
0.14 \\
0.13 \\
0.12 \\
0.12\end{array}$ & $\begin{array}{c}1300.0 \\
1259.8 \\
335.6 \\
172.4 \\
122.8 \\
973.1\end{array}$ & $\begin{array}{l}4.0 \\
3.3 \\
6.3 \\
3.5 \\
6.4 \\
4.3\end{array}$ & \begin{tabular}{r|}
34.2 \\
31.7 \\
6.4 \\
7.5 \\
8.2 \\
7.5
\end{tabular} & $\begin{array}{l}0.4 \\
0.5 \\
0.1 \\
0.1 \\
0.1 \\
0.1\end{array}$ \\
\hline $2--1$ & $\begin{array}{l}\text { Oi } \\
\text { Oe } \\
\text { M1 } \\
\text { M2 } \\
\text { M3 } \\
\text { M4 } \\
\text { M5 } \\
\text { Oe } \\
\end{array}$ & $\begin{array}{c}0--7 \\
7--18 \\
18--28 \\
28--38 \\
38--58 \\
58--88 \\
88--124 \\
66-82\end{array}$ & $\begin{array}{l}5.1 \\
5.1 \\
4.2 \\
4.4 \\
4.9 \\
4.3 \\
4.2 \\
4.5 \\
\end{array}$ & $\begin{array}{l}0.08 \\
0.12 \\
0.21 \\
0.21 \\
0.14 \\
0.22 \\
0.05 \\
0.28 \\
\end{array}$ & $\begin{array}{c}278.8 \\
913.7 \\
1118.7 \\
340.9 \\
258.0 \\
112.6 \\
428.1 \\
272.1 \\
\end{array}$ & $\begin{array}{l}2.5 \\
1.5 \\
1.8 \\
1.2 \\
1.4 \\
3.9 \\
5.1 \\
3.7 \\
\end{array}$ & $\begin{array}{c}24.7 \\
12.7 \\
6.6 \\
9.8 \\
25.4 \\
11.0 \\
2.0 \\
20.4 \\
\end{array}$ & $\begin{array}{l}0.1 \\
0.2 \\
0.1 \\
0.1 \\
0.2 \\
0.1 \\
0.0 \\
0.3 \\
\end{array}$ \\
\hline $2--2$ & $\begin{array}{l}\mathrm{Oi} \\
\mathrm{Oe} \\
\mathrm{Oa} \\
\mathrm{Oa} \\
\mathrm{M} 1 \\
\mathrm{M} 2 \\
\mathrm{M} 3 \\
\end{array}$ & $\begin{array}{c}0--9 \\
9--16 \\
16--24 \\
24--34 \\
34--54 \\
54--84 \\
84--124 \\
\end{array}$ & $\begin{array}{l}5.9 \\
5.5 \\
5.0 \\
4.4 \\
4.6 \\
3.9 \\
4.3 \\
\end{array}$ & $\begin{array}{l}0.17 \\
0.16 \\
0.15 \\
0.15 \\
0.09 \\
0.77 \\
0.18 \\
\end{array}$ & $\begin{array}{c}542.8 \\
303.9 \\
247.3 \\
194.9 \\
174.1 \\
139.0 \\
57.5 \\
\end{array}$ & $\begin{array}{l}4.5 \\
0.8 \\
2.1 \\
9.1 \\
7.6 \\
6.8 \\
0.7 \\
\end{array}$ & $\begin{array}{c}39.2 \\
26.8 \\
21.7 \\
16.4 \\
11.2 \\
9.6 \\
1.2 \\
\end{array}$ & $\begin{array}{c}1.0 \\
1.2 \\
0.7 \\
0.3 \\
0.2 \\
0.2 \\
\text { BDL } \\
\end{array}$ \\
\hline $2--3$ & $\begin{array}{l}\text { Oi } \\
\text { Oe } \\
\text { Oa } \\
\text { M1 } \\
\text { M2 }\end{array}$ & $\begin{array}{c}0--20 \\
20--28 \\
28--38 \\
38--58 \\
58--71\end{array}$ & $\begin{array}{l}3.7 \\
4.0 \\
4.1 \\
4.2 \\
4.1\end{array}$ & $\begin{array}{l}0.13 \\
0.10 \\
0.11 \\
0.07 \\
0.08\end{array}$ & $\begin{array}{c}40.1 \\
607.0 \\
85.2 \\
264.7 \\
207.7\end{array}$ & $\begin{array}{c}6.0 \\
18.5 \\
16.0 \\
20.5 \\
19.4\end{array}$ & $\begin{array}{c}41.5 \\
39.7 \\
16.3 \\
6.9 \\
6.9\end{array}$ & $\begin{array}{l}0.8 \\
0.7 \\
0.2 \\
0.1 \\
1.0\end{array}$ \\
\hline
\end{tabular}




\begin{tabular}{|c|c|c|c|c|c|c|c|c|}
\hline \multirow[t]{2}{*}{$\begin{array}{l}\text { Transect-- } \\
\text { Stop }\end{array}$} & \multirow[t]{2}{*}{ Soil Type } & \multirow{2}{*}{$\begin{array}{c}\text { Sample Depth } \\
\mathrm{cm}\end{array}$} & \multirow[t]{2}{*}{$\mathrm{pH}$} & Ec & $\mathrm{Fe}$ & $\begin{array}{c}\text { Extractable } \\
\mathrm{Al}\end{array}$ & $\mathrm{C}$ & $N$ \\
\hline & & & & $d S m^{-1}$ & $u m o l ~ g^{-1}$ & $\mathrm{cmol}_{\mathrm{C} \mathrm{kg}}{ }^{-1}$ & \multicolumn{2}{|c|}{$\%$} \\
\hline \multicolumn{9}{|c|}{ Alder Thicket } \\
\hline 1 & $\begin{array}{l}\text { Oe } \\
\text { Oa1 } \\
\text { Oa2 } \\
\text { M1 } \\
\text { M2 } \\
\text { M3 } \\
\end{array}$ & $\begin{array}{c}0--3 \\
3--9 \\
9--19 \\
19-39 \\
39--69 \\
69--109 \\
\end{array}$ & $\begin{array}{l}4.8 \\
5.1 \\
4.9 \\
4.7 \\
4.7 \\
4.6 \\
\end{array}$ & $\begin{array}{l}0.13 \\
0.07 \\
0.09 \\
0.05 \\
0.06 \\
0.11 \\
\end{array}$ & $\begin{array}{c}522.5 \\
91.2 \\
49.8 \\
34.3 \\
72.1 \\
131.2 \\
\end{array}$ & $\begin{array}{c}2.4 \\
1.7 \\
2.2 \\
10.2 \\
7.2 \\
1.8 \\
\end{array}$ & $\begin{array}{c}41.1 \\
35.4 \\
21.8 \\
9.5 \\
10.4 \\
4.6 \\
\end{array}$ & $\begin{array}{l}1.9 \\
1.5 \\
0.9 \\
0.1 \\
0.2 \\
0.1 \\
\end{array}$ \\
\hline 3 & $\begin{array}{l}\text { Oe } \\
\text { Oa } \\
\text { Oa } \\
\text { M1 } \\
\text { M2 } \\
\text { M3 }\end{array}$ & $\begin{array}{c}0--3 \\
03--25 \\
25--35 \\
35--55 \\
55-85 \\
85--125 \\
\end{array}$ & $\begin{array}{l}5.9 \\
5.8 \\
5.8 \\
4.8 \\
4.7 \\
5.0\end{array}$ & $\begin{array}{l}0.14 \\
0.11 \\
0.10 \\
0.09 \\
0.08 \\
0.13 \\
\end{array}$ & $\begin{array}{c}848.2 \\
554.0 \\
56.5 \\
30.8 \\
33.7 \\
150.9 \\
\end{array}$ & $\begin{array}{l}0.1 \\
0.4 \\
0.2 \\
7.2 \\
5.3 \\
1.1 \\
\end{array}$ & $\begin{array}{c}32.1 \\
35.9 \\
16.2 \\
9.1 \\
8.1 \\
11.3 \\
\end{array}$ & $\begin{array}{l}1.4 \\
1.3 \\
0.4 \\
0.1 \\
0.1 \\
0.3\end{array}$ \\
\hline \multicolumn{9}{|c|}{ Forested Wetland } \\
\hline 1 & $\begin{array}{l}\text { Oe } \\
\text { M1 } \\
\text { M2 } \\
\text { M3 } \\
\text { M4 } \\
\text { M5 } \\
\end{array}$ & $\begin{array}{c}0--7 \\
7--11 \\
11--21 \\
21--41 \\
41--71 \\
71--111 \\
\end{array}$ & $\begin{array}{l}4.3 \\
3.8 \\
3.9 \\
4.2 \\
4.6 \\
5.2 \\
\end{array}$ & $\begin{array}{l}0.23 \\
0.12 \\
0.09 \\
0.06 \\
0.04 \\
0.05 \\
\end{array}$ & $\begin{array}{c}169.8 \\
252.7 \\
68.6 \\
1081.9 \\
370.1 \\
644.8 \\
\end{array}$ & $\begin{array}{c}8.5 \\
9.1 \\
10.0 \\
6.3 \\
4.1 \\
0.6 \\
\end{array}$ & $\begin{array}{l}33.8 \\
5.6 \\
2.4 \\
2.4 \\
4.6 \\
3.9 \\
\end{array}$ & $\begin{array}{c}1.5 \\
0.2 \\
0.0 \\
\mathrm{BDL} \\
0.0 \\
0.0 \\
\end{array}$ \\
\hline 2 & $\begin{array}{l}\text { Oe } \\
\text { Oa } \\
\text { M1 } \\
\text { M2 } \\
\text { M3 } \\
\text { M4 } \\
\end{array}$ & $\begin{array}{c}0--4 \\
4--14 \\
14--34 \\
34--64 \\
64--104 \\
104--150 \\
\end{array}$ & $\begin{array}{l}4.0 \\
3.6 \\
3.7 \\
3.9 \\
4.3 \\
4.8 \\
\end{array}$ & $\begin{array}{l}0.21 \\
0.24 \\
0.07 \\
0.06 \\
0.04 \\
0.03 \\
\end{array}$ & $\begin{array}{l}109.0 \\
184.9 \\
194.3 \\
206.2 \\
466.6 \\
549.4 \\
\end{array}$ & $\begin{array}{c}7.9 \\
17.0 \\
9.1 \\
6.3 \\
5.5 \\
2.1 \\
\end{array}$ & $\begin{array}{l}40.5 \\
26.8 \\
6.0 \\
1.6 \\
1.8 \\
2.3 \\
\end{array}$ & $\begin{array}{c}1.2 \\
0.9 \\
0.1 \\
\text { BDL } \\
\text { BDL } \\
0.0 \\
\end{array}$ \\
\hline \multicolumn{9}{|c|}{ Scrub Shrub } \\
\hline 1 & $\begin{array}{l}\text { Oa } \\
\text { M1 } \\
\text { M2 } \\
\text { M3 } \\
\text { M4 } \\
\end{array}$ & $\begin{array}{c}0--4 \\
4--14 \\
14--34 \\
34--64 \\
64--104 \\
\end{array}$ & $\begin{array}{l}3.8 \\
3.8 \\
4.0 \\
4.2 \\
4.4 \\
\end{array}$ & $\begin{array}{l}0.17 \\
0.10 \\
0.07 \\
0.06 \\
0.05 \\
\end{array}$ & $\begin{array}{l}106.5 \\
145.6 \\
190.8 \\
416.4 \\
646.4 \\
\end{array}$ & $\begin{array}{l}4.1 \\
9.1 \\
9.9 \\
4.9 \\
3.6 \\
\end{array}$ & $\begin{array}{c}23.2 \\
5.7 \\
3.5 \\
0.9 \\
1.0 \\
\end{array}$ & $\begin{array}{c}0.9 \\
0.1 \\
0.1 \\
0.0 \\
\mathrm{BDL}\end{array}$ \\
\hline 2 & $\begin{array}{l}\text { Oa } \\
\text { M1 } \\
\text { M2 } \\
\text { M3 } \\
\text { M4 }\end{array}$ & $\begin{array}{c}0--9 \\
9--19 \\
19--39 \\
39--69 \\
69--109\end{array}$ & $\begin{array}{l}4.0 \\
3.8 \\
3.9 \\
4.1 \\
4.7\end{array}$ & $\begin{array}{l}0.18 \\
0.10 \\
0.05 \\
0.03 \\
0.01\end{array}$ & $\begin{array}{c}85.8 \\
67.9 \\
415.1 \\
426.5 \\
354.4\end{array}$ & $\begin{array}{c}5.5 \\
12.7 \\
10.4 \\
6.5 \\
3.9\end{array}$ & $\begin{array}{c}31.3 \\
8.1 \\
2.4 \\
0.7 \\
0.6\end{array}$ & $\begin{array}{c}1.1 \\
0.2 \\
0.0 \\
0.0 \\
\text { BDL }\end{array}$ \\
\hline
\end{tabular}




\begin{tabular}{|c|c|c|c|c|c|c|c|c|}
\hline \multirow[t]{2}{*}{$\begin{array}{l}\text { Transect-- } \\
\text { Stop }\end{array}$} & \multirow[t]{2}{*}{ Soil Type } & \multirow{2}{*}{$\begin{array}{c}\text { Sample Depth } \\
\mathrm{cm}\end{array}$} & \multirow[t]{2}{*}{$\mathrm{pH}$} & Ec & $\mathrm{Fe}$ & $\begin{array}{c}\text { Extractable } \\
\mathrm{Al}\end{array}$ & C & $\mathrm{N}$ \\
\hline & & & & $\mathrm{dS} \mathrm{m}^{-1}$ & $u \mathrm{~mol} \mathrm{~g}^{-1}$ & $\mathrm{cmolc} \mathrm{kg}^{-1}$ & \multicolumn{2}{|c|}{$\%$} \\
\hline \multicolumn{9}{|c|}{ Fen-Marsh } \\
\hline $1--2$ & $\begin{array}{l}\text { Oi } \\
\text { Oe } \\
\text { Oa } \\
\text { Oa } \\
\text { Oa } \\
\text { M1 } \\
\text { M2 } \\
\text { M3 }\end{array}$ & $\begin{array}{c}0--8 \\
8--16 \\
16--41 \\
41--48 \\
48--58 \\
58--78 \\
78--108 \\
108--148\end{array}$ & $\begin{array}{l}4.8 \\
5.7 \\
5.3 \\
4.6 \\
4.8 \\
4.7 \\
4.8 \\
4.8\end{array}$ & $\begin{array}{l}0.07 \\
0.11 \\
0.10 \\
0.14 \\
0.11 \\
0.06 \\
0.07 \\
0.06\end{array}$ & $\begin{array}{l}371.0 \\
629.8 \\
105.8 \\
69.5 \\
46.8 \\
28.6 \\
44.8 \\
57.7\end{array}$ & $\begin{array}{l}7.7 \\
1.6 \\
2.4 \\
7.8 \\
3.6 \\
6.0 \\
1.2 \\
2.8 \\
\end{array}$ & \begin{tabular}{c|}
35.0 \\
32.1 \\
31.0 \\
33.4 \\
28.5 \\
7.8 \\
4.8 \\
4.9 \\
\end{tabular} & $\begin{array}{l}1.3 \\
1.5 \\
1.4 \\
1.2 \\
0.9 \\
0.1 \\
0.0 \\
0.1\end{array}$ \\
\hline $2--1$ & $\begin{array}{l}\mathrm{Oi} \\
\mathrm{Oe} \\
\mathrm{Oa} \\
\mathrm{Oa} \\
\mathrm{Oa} \\
\end{array}$ & $\begin{array}{c}0--4 \\
4--42 \\
42--52 \\
52--72 \\
72--102 \\
\end{array}$ & $\begin{array}{l}4.9 \\
5.7 \\
6.0 \\
6.1 \\
5.7 \\
\end{array}$ & $\begin{array}{l}0.31 \\
0.17 \\
0.21 \\
0.13 \\
0.09 \\
\end{array}$ & $\begin{array}{c}854.5 \\
565.8 \\
80.4 \\
71.3 \\
75.3 \\
\end{array}$ & $\begin{array}{l}6.2 \\
0.3 \\
0.1 \\
0.1 \\
0.1 \\
\end{array}$ & $\begin{array}{l}32.8 \\
18.7 \\
25.5 \\
24.1 \\
24.9 \\
\end{array}$ & $\begin{array}{l}1.3 \\
0.9 \\
1.4 \\
1.3 \\
1.1\end{array}$ \\
\hline $2--3$ & $\begin{array}{l}\mathrm{Oe} \\
\mathrm{Oa} \\
\mathrm{Oa} \\
\mathrm{Oa} \\
\mathrm{Oa} \\
\mathrm{Oa}\end{array}$ & $\begin{array}{c}0--21 \\
21-31 \\
31-41 \\
41-61 \\
61-91 \\
91-120+\end{array}$ & $\begin{array}{l}4.0 \\
4.1 \\
3.9 \\
3.8 \\
3.9 \\
4.1 \\
\end{array}$ & $\begin{array}{l}0.05 \\
0.11 \\
0.10 \\
0.14 \\
0.09 \\
0.08\end{array}$ & $\begin{array}{l}87.9 \\
36.3 \\
36.8 \\
31.9 \\
42.9 \\
91.5 \\
\end{array}$ & $\begin{array}{c}8.2 \\
9.9 \\
15.5 \\
17.8 \\
20.7 \\
18.9 \\
\end{array}$ & $\begin{array}{l}42.8 \\
44.5 \\
48.3 \\
49.5 \\
49.5 \\
47.0 \\
\end{array}$ & $\begin{array}{l}0.8 \\
1.5 \\
1.1 \\
1.0 \\
1.0 \\
1.0\end{array}$ \\
\hline $2--4$ & $\begin{array}{l}\mathrm{Oi} \\
\mathrm{Oe} \\
\mathrm{Oa} \\
\mathrm{Oa} \\
\mathrm{Oa} \\
\mathrm{Oa} \\
\mathrm{M} 1\end{array}$ & $\begin{array}{c}0--23 \\
23--33 \\
33--43 \\
43--53 \\
53--73 \\
73--103 \\
103--143 \\
\end{array}$ & $\begin{array}{l}3.8 \\
3.9 \\
3.8 \\
3.7 \\
3.7 \\
4.1 \\
3.9\end{array}$ & $\begin{array}{l}0.08 \\
0.11 \\
0.13 \\
0.10 \\
0.09 \\
0.15 \\
0.07 \\
\end{array}$ & $\begin{array}{c}94.8 \\
62.7 \\
47.7 \\
53.0 \\
72.7 \\
212.3 \\
112.6 \\
\end{array}$ & $\begin{array}{l}13.0 \\
19.7 \\
15.1 \\
18.1 \\
23.0 \\
16.5 \\
4.7 \\
\end{array}$ & $\begin{array}{c}42.6 \\
42.8 \\
41.1 \\
46.9 \\
45.3 \\
31.9 \\
2.0 \\
\end{array}$ & $\begin{array}{l}0.8 \\
1.0 \\
1.0 \\
0.9 \\
0.8 \\
0.7 \\
0.0\end{array}$ \\
\hline
\end{tabular}

* BDL - Below Detection Limit 
118

Table 10. Cation exchange capacity (CEC); exchangeable calcium (Ca), magnesium (Mg), sodium (Na), and potassium (K); and sum of all exchangeable bases for all wetland soils.

\begin{tabular}{|c|c|c|c|c|c|c|c|c|}
\hline \multirow[t]{2}{*}{ Stop } & \multirow[t]{2}{*}{ Soil Type } & $\begin{array}{c}\text { Sample } \\
\text { Depth }\end{array}$ & CEC & $\mathrm{Ca}$ & $\mathrm{Mg}$ & $\mathrm{Na}$ & $\mathrm{K}$ & Sum \\
\hline & & $\mathrm{cm}$ & \multicolumn{6}{|c|}{$\mathrm{cmol}_{\mathrm{C}} \mathrm{kg}^{-1}$} \\
\hline \multicolumn{9}{|c|}{ Narrow Wetland } \\
\hline 2 & $\begin{array}{l}\text { Oi } \\
\text { M1 } \\
\text { M2 } \\
\text { M3 } \\
\end{array}$ & $\begin{array}{c}0-5 \\
5--15 \\
15--35 \\
35--65 \\
\end{array}$ & $\begin{array}{l}26.3 \\
18.5 \\
16.3 \\
13.6 \\
\end{array}$ & $\begin{array}{l}2.1 \\
1.7 \\
1.2 \\
1.8 \\
\end{array}$ & $\begin{array}{l}1.2 \\
1.0 \\
0.8 \\
1.1 \\
\end{array}$ & $\begin{array}{l}0.5 \\
0.1 \\
0.1 \\
0.1 \\
\end{array}$ & $\begin{array}{l}0.8 \\
0.2 \\
0.2 \\
0.1 \\
\end{array}$ & $\begin{array}{l}4.6 \\
3.0 \\
2.3 \\
3.1 \\
\end{array}$ \\
\hline 4 & $\begin{array}{l}\text { Oi } \\
\text { Oe } \\
\text { Oe } \\
\text { M1 } \\
\text { M2 } \\
\text { M3 } \\
\end{array}$ & $\begin{array}{c}0--6 \\
6--15 \\
15--23 \\
23--33 \\
33--53 \\
53--83 \\
\end{array}$ & $\begin{array}{l}49.0 \\
46.1 \\
40.7 \\
16.5 \\
13.7 \\
14.6 \\
\end{array}$ & $\begin{array}{l}54.8 \\
36.2 \\
44.8 \\
15.4 \\
13.6 \\
16.8 \\
\end{array}$ & $\begin{array}{l}6.8 \\
5.3 \\
5.9 \\
2.2 \\
1.9 \\
1.9 \\
\end{array}$ & $\begin{array}{c}0.5 \\
1.7 \\
2.4 \\
\text { BDL* }^{*} \\
0.1 \\
0.2 \\
\end{array}$ & $\begin{array}{l}1.1 \\
1.0 \\
0.9 \\
0.2 \\
0.1 \\
0.1 \\
\end{array}$ & $\begin{array}{l}63.2 \\
44.2 \\
54.0 \\
17.8 \\
15.7 \\
19.0 \\
\end{array}$ \\
\hline 6 & $\begin{array}{l}\text { Oi } \\
\text { M1 } \\
\text { M2 } \\
\text { M3 } \\
\end{array}$ & $\begin{array}{c}0--42 \\
42--52 \\
52--72 \\
72--102 \\
\end{array}$ & $\begin{array}{l}41.4 \\
14.9 \\
18.2 \\
22.5 \\
\end{array}$ & $\begin{array}{c}30.1 \\
8.5 \\
8.7 \\
13.4 \\
\end{array}$ & $\begin{array}{l}7.7 \\
2.4 \\
2.3 \\
3.6 \\
\end{array}$ & $\begin{array}{l}0.9 \\
0.2 \\
0.1 \\
0.1 \\
\end{array}$ & $\begin{array}{l}1.1 \\
0.2 \\
0.1 \\
0.1\end{array}$ & $\begin{array}{l}39.8 \\
11.3 \\
11.3 \\
17.4 \\
\end{array}$ \\
\hline \multicolumn{9}{|c|}{ Iron Pond } \\
\hline 1 & $\begin{array}{l}\text { Oi } \\
\text { Oe } \\
\text { M1 } \\
\text { M2 } \\
\text { M3 } \\
\end{array}$ & $\begin{array}{c}0--7 \\
7--9 \\
9--19 \\
19--39 \\
39--69 \\
\end{array}$ & $\begin{array}{c}40.0 \\
23.1 \\
18.0 \\
4.6 \\
5.6 \\
\end{array}$ & $\begin{array}{c}30.0 \\
14.1 \\
9.4 \\
1.8 \\
2.4 \\
\end{array}$ & $\begin{array}{l}10.4 \\
4.6 \\
3.8 \\
0.7 \\
0.9 \\
\end{array}$ & $\begin{array}{c}0.4 \\
0.2 \\
0.2 \\
\text { BDL } \\
\text { BDL }\end{array}$ & $\begin{array}{l}0.5 \\
0.4 \\
0.3 \\
0.1 \\
0.1\end{array}$ & $\begin{array}{c}41.4 \\
19.3 \\
13.8 \\
2.7 \\
3.5 \\
\end{array}$ \\
\hline 2 & $\begin{array}{l}\text { Oi } \\
\text { M1 } \\
\text { M2 } \\
\text { M3 } \\
\text { M4 } \\
\end{array}$ & $\begin{array}{c}0--23 \\
23--45 \\
45-55 \\
55-75 \\
75--105 \\
\end{array}$ & $\begin{array}{c}19.7 \\
7.1 \\
4.2 \\
4.0 \\
6.7 \\
\end{array}$ & $\begin{array}{c}14.3 \\
4.4 \\
2.8 \\
1.3 \\
3.1 \\
\end{array}$ & $\begin{array}{l}5.3 \\
1.8 \\
1.4 \\
2.2 \\
1.8 \\
\end{array}$ & $\begin{array}{c}0.3 \\
0.1 \\
0.1 \\
\text { BDL } \\
0.1 \\
\end{array}$ & $\begin{array}{l}0.5 \\
0.2 \\
0.1 \\
0.1 \\
0.2\end{array}$ & $\begin{array}{c}20.4 \\
6.4 \\
4.3 \\
3.6 \\
5.2 \\
\end{array}$ \\
\hline 3 & $\begin{array}{l}\text { M/Oi } \\
\text { M1 } \\
\text { M2 } \\
\text { M3 }\end{array}$ & $\begin{array}{c}0--22 \\
22--32 \\
32--52 \\
52--82\end{array}$ & $\begin{array}{c}12.0 \\
6.9 \\
6.6 \\
8.1 \\
\end{array}$ & $\begin{array}{l}3.1 \\
3.1 \\
2.8 \\
3.2 \\
\end{array}$ & $\begin{array}{l}1.6 \\
1.9 \\
2.0 \\
2.5 \\
\end{array}$ & $\begin{array}{c}0.3 \\
0.1 \\
\mathrm{BDL} \\
\mathrm{BDL}\end{array}$ & $\begin{array}{l}0.6 \\
0.2 \\
0.2 \\
0.2 \\
\end{array}$ & $\begin{array}{l}5.6 \\
5.2 \\
5.0 \\
6.0\end{array}$ \\
\hline 4 & $\begin{array}{l}\text { Oi } \\
\text { M1 } \\
\text { M2 } \\
\text { M3 } \\
\text { M4 } \\
\end{array}$ & $\begin{array}{c}0--21 \\
21--32 \\
32--42 \\
42--62 \\
62--92 \\
\end{array}$ & $\begin{array}{c}41.4 \\
13.7 \\
6.1 \\
8.4 \\
4.3 \\
\end{array}$ & $\begin{array}{l}4.2 \\
4.5 \\
2.3 \\
2.2 \\
1.9 \\
\end{array}$ & $\begin{array}{l}2.5 \\
2.4 \\
1.8 \\
2.2 \\
0.9 \\
\end{array}$ & $\begin{array}{c}0.2 \\
0.2 \\
0.1 \\
\mathrm{BDL} \\
\mathrm{BDL} \\
\end{array}$ & $\begin{array}{l}0.3 \\
0.5 \\
0.1 \\
0.2 \\
0.1 \\
\end{array}$ & $\begin{array}{l}7.1 \\
7.6 \\
4.2 \\
4.6 \\
3.0 \\
\end{array}$ \\
\hline 5 & $\begin{array}{l}\text { Oi } \\
\text { M1 } \\
\text { M2 } \\
\text { M3 } \\
\text { M4 } \\
\text { M5 } \\
\text { M6 }\end{array}$ & $\begin{array}{c}0--18 \\
18--31 \\
31--50 \\
50--64 \\
64--74 \\
74--94 \\
94-124\end{array}$ & $\begin{array}{c}22.6 \\
13.6 \\
11.1 \\
6.5 \\
6.9 \\
6.6 \\
6.1\end{array}$ & $\begin{array}{l}2.5 \\
5.4 \\
4.4 \\
3.0 \\
3.2 \\
2.9 \\
3.3\end{array}$ & $\begin{array}{l}1.5 \\
2.9 \\
2.4 \\
2.7 \\
2.2 \\
1.6 \\
1.7\end{array}$ & $\begin{array}{c}0.7 \\
0.3 \\
0.2 \\
\text { BDL } \\
0.1 \\
\text { BDL } \\
0.1\end{array}$ & $\begin{array}{l}0.4 \\
0.5 \\
0.5 \\
0.2 \\
0.2 \\
0.2 \\
0.2\end{array}$ & $\begin{array}{l}5.1 \\
8.9 \\
7.4 \\
5.9 \\
5.7 \\
4.7 \\
5.3\end{array}$ \\
\hline
\end{tabular}




\begin{tabular}{|c|c|c|c|c|c|c|c|c|}
\hline Transect-Stop & Soil Type & $\begin{array}{c}\text { Sample } \\
\text { Depth }\end{array}$ & CEC & $\mathrm{Ca}$ & $\mathrm{Mg}$ & $\mathrm{Na}$ & K & Sum \\
\hline & & $\mathrm{cm}$ & \multicolumn{6}{|c|}{$\mathrm{cmol}_{\mathrm{C}} \mathrm{kg}^{-1}$} \\
\hline \multicolumn{9}{|c|}{ Railroad Grade } \\
\hline $1--1$ & $\begin{array}{l}\text { Oi } \\
\text { Oe } \\
\text { Oa } \\
\text { M1 } \\
\text { M2 }\end{array}$ & $\begin{array}{c}0--18 \\
18--25 \\
25--35 \\
35--55 \\
55--85\end{array}$ & $\begin{array}{l}51.1 \\
61.6 \\
48.6 \\
16.9 \\
10.8\end{array}$ & $\begin{array}{l}9.6 \\
7.8 \\
2.5 \\
1.5 \\
2.6\end{array}$ & $\begin{array}{l}2.3 \\
1.3 \\
0.8 \\
0.9 \\
1.7\end{array}$ & $\begin{array}{l}0.6 \\
0.6 \\
0.1 \\
0.1 \\
0.1\end{array}$ & $\begin{array}{l}0.7 \\
0.3 \\
0.1 \\
0.1 \\
0.2\end{array}$ & $\begin{array}{l}13.1 \\
9.9 \\
3.5 \\
2.7 \\
4.7\end{array}$ \\
\hline $1--2$ & $\begin{array}{c}\text { Oi } \\
\text { Oe } \\
\text { Oa1 } \\
\text { Oa2 } \\
\text { M1 } \\
\text { M2 } \\
\end{array}$ & $\begin{array}{c}0--33 \\
33--40 \\
40--45 \\
45-55 \\
55--75 \\
75--82 \\
\end{array}$ & $\begin{array}{l}46.1 \\
57.5 \\
56.7 \\
46.2 \\
18.6 \\
15.9 \\
\end{array}$ & $\begin{array}{c}10.7 \\
12.2 \\
10.6 \\
3.1 \\
1.1 \\
3.1 \\
\end{array}$ & $\begin{array}{l}5.6 \\
3.2 \\
2.6 \\
1.0 \\
0.7 \\
1.0 \\
\end{array}$ & $\begin{array}{l}1.8 \\
2.7 \\
1.1 \\
1.1 \\
0.2 \\
0.3 \\
\end{array}$ & $\begin{array}{l}3.7 \\
0.3 \\
0.2 \\
0.2 \\
0.2 \\
0.1 \\
\end{array}$ & $\begin{array}{c}21.8 \\
18.4 \\
14.5 \\
5.4 \\
2.1 \\
4.5 \\
\end{array}$ \\
\hline $1-4$ & $\begin{array}{l}\text { Oi } \\
\text { Oe } \\
\text { M1 } \\
\text { M2 } \\
\text { M3 } \\
\text { M4 } \\
\end{array}$ & $\begin{array}{c}0--13 \\
13--17 \\
17--27 \\
27--47 \\
47--77 \\
40--50 \\
\end{array}$ & \begin{tabular}{l|}
27.2 \\
37.9 \\
18.4 \\
17.7 \\
22.5 \\
21.0 \\
\end{tabular} & \begin{tabular}{c|}
8.9 \\
22.3 \\
1.3 \\
3.2 \\
4.7 \\
3.8 \\
\end{tabular} & $\begin{array}{l}3.0 \\
8.8 \\
0.8 \\
1.2 \\
1.8 \\
1.4 \\
\end{array}$ & $\begin{array}{l}2.5 \\
2.1 \\
0.1 \\
0.1 \\
0.2 \\
0.1\end{array}$ & $\begin{array}{l}4.5 \\
1.5 \\
0.1 \\
0.1 \\
0.1 \\
0.1 \\
\end{array}$ & $\begin{array}{c}18.9 \\
34.7 \\
2.3 \\
4.7 \\
6.7 \\
5.5\end{array}$ \\
\hline $2--2$ & $\begin{array}{l}\text { Oi } \\
\text { Oe } \\
\text { Oa } \\
\text { Oa } \\
\text { M1 } \\
\text { M2 } \\
\text { M3 }\end{array}$ & $\begin{array}{c}0--9 \\
9--16 \\
16--24 \\
24--34 \\
34--54 \\
54--84 \\
84--124\end{array}$ & \begin{tabular}{c|}
67.0 \\
55.7 \\
46.5 \\
39.3 \\
32.9 \\
25.2 \\
4.7
\end{tabular} & $\begin{array}{c}80.3 \\
47.3 \\
25.4 \\
10.5 \\
9.2 \\
7.5 \\
1.7\end{array}$ & $\begin{array}{l}7.5 \\
3.8 \\
3.2 \\
2.9 \\
2.7 \\
2.6 \\
0.5\end{array}$ & $\begin{array}{l}3.8 \\
2.2 \\
0.8 \\
0.5 \\
0.4 \\
0.1 \\
0.1\end{array}$ & $\begin{array}{c}3.3 \\
1.0 \\
0.2 \\
0.1 \\
0.1 \\
0.2 \\
\text { BDL }\end{array}$ & $\begin{array}{l}94.8 \\
54.3 \\
29.6 \\
14.0 \\
12.3 \\
10.3 \\
2.3\end{array}$ \\
\hline $2--3$ & $\begin{array}{l}\mathrm{Oi} \\
\mathrm{Oe} \\
\mathrm{Oa} \\
\mathrm{M} 1 \\
\mathrm{M} 2 \\
\end{array}$ & $\begin{array}{c}0--20 \\
20--28 \\
28--38 \\
38--58 \\
58--71 \\
\end{array}$ & $\begin{array}{l}72.8 \\
82.4 \\
33.5 \\
30.4 \\
28.0 \\
\end{array}$ & $\begin{array}{l}17.8 \\
6.9 \\
2.5 \\
1.4 \\
1.4 \\
\end{array}$ & $\begin{array}{l}5.2 \\
1.9 \\
1.0 \\
0.7 \\
0.8 \\
\end{array}$ & $\begin{array}{l}1.8 \\
1.7 \\
0.5 \\
0.3 \\
0.3 \\
\end{array}$ & $\begin{array}{l}1.7 \\
1.1 \\
0.1 \\
0.2 \\
0.2 \\
\end{array}$ & $\begin{array}{c}26.5 \\
11.6 \\
4.2 \\
2.6 \\
2.7 \\
\end{array}$ \\
\hline
\end{tabular}


120

\begin{tabular}{|c|c|c|c|c|c|c|c|c|}
\hline Stop & Soil Type & $\begin{array}{l}\text { Sample } \\
\text { Depth }\end{array}$ & CEC & $\mathrm{Ca}$ & $\mathrm{Mg}$ & $\mathrm{Na}$ & K & Sum \\
\hline & & $\mathrm{cm}$ & \multicolumn{6}{|c|}{$\mathrm{cmol}_{\mathrm{C} \mathrm{kg}}{ }^{-1}$} \\
\hline \multicolumn{9}{|c|}{ Alder Thicket } \\
\hline 1 & $\begin{array}{l}\text { Oe } \\
\text { Oa1 } \\
\text { Oa2 } \\
\text { M1 } \\
\text { M2 } \\
\text { M3 } \\
\end{array}$ & $\begin{array}{c}0--3 \\
3--9 \\
9--19 \\
19-39 \\
39--69 \\
69--109 \\
\end{array}$ & $\begin{array}{l}59.3 \\
55.8 \\
39.0 \\
27.4 \\
24.4 \\
12.1 \\
\end{array}$ & $\begin{array}{c}25.1 \\
26.8 \\
17.4 \\
8.0 \\
5.9 \\
4.4 \\
\end{array}$ & $\begin{array}{l}5.8 \\
6.9 \\
5.0 \\
3.0 \\
2.9 \\
2.2 \\
\end{array}$ & $\begin{array}{l}0.5 \\
0.3 \\
0.2 \\
0.1 \\
0.2 \\
0.1 \\
\end{array}$ & $\begin{array}{l}1.0 \\
0.2 \\
0.2 \\
0.2 \\
0.2 \\
0.1 \\
\end{array}$ & $\begin{array}{c}32.4 \\
34.2 \\
22.9 \\
11.4 \\
9.1 \\
6.8 \\
\end{array}$ \\
\hline 3 & $\begin{array}{l}\text { Oe } \\
\text { Oa } \\
\text { Oa } \\
\text { M1 } \\
\text { M2 } \\
\text { M3 }\end{array}$ & $\begin{array}{c}0--3 \\
03--25 \\
25--35 \\
35--55 \\
55-85 \\
85--125 \\
\end{array}$ & $\begin{array}{l}46.5 \\
70.8 \\
30.2 \\
23.1 \\
20.9 \\
25.2 \\
\end{array}$ & $\begin{array}{c}53.6 \\
69.7 \\
25.7 \\
7.2 \\
5.9 \\
9.3 \\
\end{array}$ & $\begin{array}{c}9.2 \\
13.2 \\
5.8 \\
2.4 \\
2.7 \\
4.3 \\
\end{array}$ & $\begin{array}{l}0.5 \\
0.3 \\
0.2 \\
0.2 \\
0.2 \\
0.2 \\
\end{array}$ & $\begin{array}{l}1.3 \\
0.3 \\
0.1 \\
0.2 \\
0.2 \\
0.2 \\
\end{array}$ & $\begin{array}{c}64.6 \\
83.6 \\
31.8 \\
10.1 \\
8.9 \\
14.1 \\
\end{array}$ \\
\hline \multicolumn{9}{|c|}{ Forested Wetland } \\
\hline 1 & $\begin{array}{l}\text { Oi } \\
\text { M1 } \\
\text { M2 } \\
\text { M3 } \\
\text { M4 } \\
\text { M5 } \\
\end{array}$ & $\begin{array}{c}0--7 \\
7--11 \\
11--21 \\
21--41 \\
41--71 \\
71--111 \\
\end{array}$ & $\begin{array}{l}55.1 \\
20.2 \\
14.5 \\
12.1 \\
12.5 \\
11.4 \\
\end{array}$ & $\begin{array}{c}12.5 \\
1.8 \\
1.1 \\
0.8 \\
1.6 \\
4.7 \\
\end{array}$ & $\begin{array}{l}2.6 \\
0.5 \\
0.3 \\
0.2 \\
0.6 \\
0.6 \\
\end{array}$ & $\begin{array}{l}0.7 \\
0.9 \\
0.1 \\
0.1 \\
0.1 \\
0.1 \\
\end{array}$ & $\begin{array}{l}2.7 \\
0.3 \\
0.1 \\
0.1 \\
0.1 \\
0.1 \\
\end{array}$ & $\begin{array}{c}18.5 \\
3.5 \\
1.6 \\
1.2 \\
2.3 \\
5.6 \\
\end{array}$ \\
\hline 2 & $\begin{array}{l}\text { Oe } \\
\text { Oa } \\
\text { M1 } \\
\text { M2 } \\
\text { M3 } \\
\text { M4 } \\
\end{array}$ & $\begin{array}{c}0--4 \\
4--14 \\
14--34 \\
34--64 \\
64--104 \\
104--150 \\
\end{array}$ & $\begin{array}{c}61.4 \\
56.7 \\
18.2 \\
10.5 \\
9.4 \\
8.7 \\
\end{array}$ & $\begin{array}{c}10.4 \\
1.5 \\
0.3 \\
0.2 \\
0.4 \\
1.9 \\
\end{array}$ & $\begin{array}{l}2.8 \\
0.9 \\
0.2 \\
0.1 \\
0.3 \\
0.5 \\
\end{array}$ & $\begin{array}{l}0.6 \\
0.3 \\
0.1 \\
0.1 \\
0.1 \\
0.1 \\
\end{array}$ & $\begin{array}{c}3.7 \\
1.1 \\
0.2 \\
\text { BDL } \\
0.1 \\
0.2 \\
\end{array}$ & $\begin{array}{c}17.5 \\
3.8 \\
0.7 \\
0.4 \\
0.9 \\
2.7 \\
\end{array}$ \\
\hline \multicolumn{9}{|c|}{ Scrub Shrub } \\
\hline 1 & $\begin{array}{l}\text { Oa } \\
\text { M1 } \\
\text { M2 } \\
\text { M3 } \\
\text { M4 }\end{array}$ & $\begin{array}{c}0--4 \\
4--14 \\
14--34 \\
34--64 \\
64--104\end{array}$ & $\begin{array}{c}34.9 \\
17.4 \\
15.1 \\
7.6 \\
7.6 \\
\end{array}$ & $\begin{array}{l}6.5 \\
1.0 \\
1.1 \\
0.6 \\
0.5 \\
\end{array}$ & $\begin{array}{l}2.2 \\
0.6 \\
0.7 \\
0.3 \\
0.3 \\
\end{array}$ & $\begin{array}{l}0.3 \\
0.1 \\
0.1 \\
0.1 \\
0.1 \\
\end{array}$ & $\begin{array}{l}1.0 \\
0.2 \\
0.1 \\
0.1 \\
0.1 \\
\end{array}$ & $\begin{array}{c}10.0 \\
1.9 \\
1.9 \\
1.1 \\
0.9 \\
\end{array}$ \\
\hline 2 & $\begin{array}{l}\text { Oa } \\
\text { M1 } \\
\text { M2 } \\
\text { M3 } \\
\text { M4 }\end{array}$ & $\begin{array}{c}0--9 \\
9--19 \\
19--39 \\
39--69 \\
69--109\end{array}$ & $\begin{array}{c}59.1 \\
25.3 \\
13.1 \\
7.1 \\
5.4\end{array}$ & $\begin{array}{l}6.0 \\
1.3 \\
0.6 \\
0.3 \\
0.3\end{array}$ & $\begin{array}{l}2.2 \\
0.7 \\
0.3 \\
0.2 \\
0.2\end{array}$ & $\begin{array}{l}0.5 \\
0.1 \\
0.1 \\
0.1 \\
0.1\end{array}$ & $\begin{array}{l}1.7 \\
0.2 \\
0.1 \\
0.1 \\
0.1\end{array}$ & $\begin{array}{l}10.4 \\
2.3 \\
1.2 \\
0.7 \\
0.8\end{array}$ \\
\hline
\end{tabular}


121

\begin{tabular}{|c|c|c|c|c|c|c|c|c|}
\hline Transect--Stop & Soil Type & $\begin{array}{c}\text { Sample } \\
\text { Depth }\end{array}$ & CEC & $\mathrm{Ca}$ & $\mathrm{Mg}$ & $\mathrm{Na}$ & K & Sum \\
\hline & & $\mathrm{cm}$ & \multicolumn{6}{|c|}{$\mathrm{cmol}_{\mathrm{C}} \mathrm{kg}^{-1}$} \\
\hline \multicolumn{9}{|c|}{ Fen-Marsh } \\
\hline $1--2$ & $\begin{array}{l}\mathrm{Oi} \\
\mathrm{Oe} \\
\mathrm{Oa} \\
\mathrm{Oa} \\
\mathrm{Oa} \\
\mathrm{M} 1 \\
\mathrm{M} 2 \\
\mathrm{M} 3 \\
\end{array}$ & $\begin{array}{c}0--8 \\
8--16 \\
16--41 \\
41--48 \\
48--58 \\
58--78 \\
78--108 \\
108--148 \\
\end{array}$ & $\begin{array}{c}45.1 \\
42.9 \\
50.7 \\
71.3 \\
50.9 \\
20.9 \\
6.6 \\
10.3 \\
\end{array}$ & $\begin{array}{c}13.0 \\
29.7 \\
24.7 \\
16.3 \\
16.7 \\
3.9 \\
1.5 \\
1.8 \\
\end{array}$ & $\begin{array}{l}2.4 \\
4.8 \\
6.0 \\
3.9 \\
3.3 \\
1.4 \\
0.6 \\
0.9 \\
\end{array}$ & $\begin{array}{l}1.1 \\
1.2 \\
0.7 \\
0.8 \\
0.7 \\
0.2 \\
0.1 \\
0.2 \\
\end{array}$ & $\begin{array}{c}0.6 \\
0.5 \\
0.3 \\
0.1 \\
0.1 \\
0.1 \\
\text { BDL } \\
\text { BDL } \\
\end{array}$ & $\begin{array}{r}17.1 \\
36.2 \\
31.7 \\
21.1 \\
20.7 \\
5.5 \\
2.2 \\
2.9 \\
\end{array}$ \\
\hline $2--1$ & $\begin{array}{l}\mathrm{Oi} \\
\mathrm{Oe} \\
\mathrm{Oa} \\
\mathrm{Oa} \\
\mathrm{Oa} \\
\end{array}$ & $\begin{array}{c}0--4 \\
4--42 \\
42--52 \\
52--72 \\
72--102 \\
\end{array}$ & $\begin{array}{l}41.5 \\
33.4 \\
56.1 \\
47.7 \\
51.7 \\
\end{array}$ & $\begin{array}{l}14.8 \\
21.6 \\
39.8 \\
36.3 \\
27.1 \\
\end{array}$ & $\begin{array}{l}3.4 \\
4.1 \\
8.1 \\
8.4 \\
7.5 \\
\end{array}$ & $\begin{array}{l}1.5 \\
0.6 \\
0.7 \\
0.5 \\
0.5\end{array}$ & $\begin{array}{l}1.8 \\
0.2 \\
0.2 \\
0.2 \\
0.2 \\
\end{array}$ & $\begin{array}{l}21.5 \\
26.5 \\
48.8 \\
45.5 \\
35.3 \\
\end{array}$ \\
\hline $2--3$ & $\begin{array}{l}\mathrm{Oe} \\
\mathrm{Oa} \\
\mathrm{Oa} \\
\mathrm{Oa} \\
\mathrm{Oa} \\
\mathrm{Oa} \\
\end{array}$ & $\begin{array}{c}0--21 \\
21-31 \\
31-41 \\
41-61 \\
61-91 \\
91-120+ \\
\end{array}$ & $\begin{array}{l}69.5 \\
73.8 \\
87.1 \\
88.0 \\
85.9 \\
82.6 \\
\end{array}$ & $\begin{array}{c}15.0 \\
15.1 \\
9.7 \\
8.7 \\
1.9 \\
2.5 \\
\end{array}$ & $\begin{array}{l}2.9 \\
1.7 \\
2.5 \\
2.5 \\
0.7 \\
0.8 \\
\end{array}$ & $\begin{array}{l}1.1 \\
0.8 \\
0.5 \\
1.0 \\
0.4 \\
0.2 \\
\end{array}$ & $\begin{array}{c}0.3 \\
0.2 \\
0.1 \\
0.1 \\
0.2 \\
\text { BDL } \\
\end{array}$ & $\begin{array}{c}19.3 \\
17.9 \\
12.8 \\
12.3 \\
3.1 \\
3.5 \\
\end{array}$ \\
\hline $2--4$ & $\begin{array}{l}\mathrm{Oi} \\
\mathrm{Oe} \\
\mathrm{Oa} \\
\mathrm{Oa} \\
\mathrm{Oa} \\
\mathrm{Oa} \\
\mathrm{M} 1 \\
\end{array}$ & $\begin{array}{c}0--23 \\
23--33 \\
33--43 \\
43--53 \\
53--73 \\
73--103 \\
103--143 \\
\end{array}$ & $\begin{array}{l}72.0 \\
57.5 \\
69.4 \\
85.8 \\
84.0 \\
61.3 \\
14.6 \\
\end{array}$ & $\begin{array}{l}3.9 \\
2.9 \\
2.5 \\
2.7 \\
1.8 \\
1.8 \\
0.7 \\
\end{array}$ & $\begin{array}{l}1.0 \\
0.7 \\
0.6 \\
0.6 \\
0.5 \\
0.8 \\
0.6\end{array}$ & $\begin{array}{l}0.3 \\
0.3 \\
0.3 \\
0.3 \\
0.2 \\
0.2 \\
0.1\end{array}$ & $\begin{array}{l}0.5 \\
0.1 \\
0.2 \\
0.1 \\
0.1 \\
0.1 \\
0.1\end{array}$ & $\begin{array}{l}5.7 \\
4.1 \\
3.6 \\
3.7 \\
2.6 \\
2.9 \\
1.5 \\
\end{array}$ \\
\hline
\end{tabular}

* BDL - Below Detection Limit 
Table 11. Redox potential (Eh) in $\mathrm{mV}$ and $\mathrm{pH}$ for one year (Dec. 2001 to Nov. 2002) at 10 and 20-cm depths for wetland soils in Elder Swamp, Iron Pond and Railroad Grade.

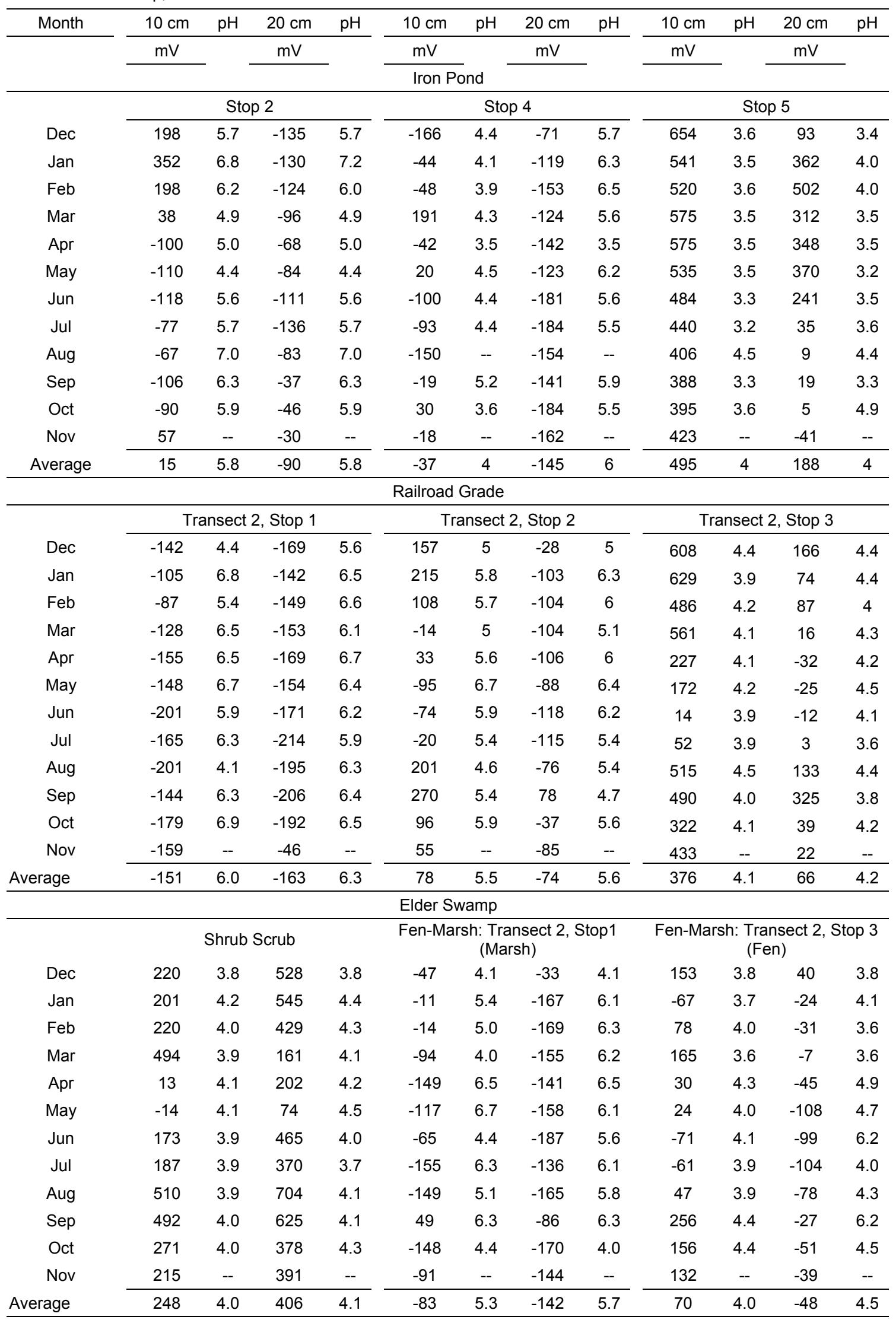


Table 12. Total Sulfur (S), sulfate sulfur $\left(\mathrm{SO}_{4}\right)$, acid volatile sulfides (AVS), chromium reducible sulfides (CRS), and organic sulfur (OS) for soils in all wetland.

\begin{tabular}{|c|c|c|c|c|c|c|c|}
\hline \multirow[t]{2}{*}{ Stop } & \multirow[t]{2}{*}{ Soil Type } & $\begin{array}{c}\text { Sample } \\
\text { Depth }\end{array}$ & $S$ & $\mathrm{SO}_{4}$ & AVS & CRS & OS \\
\hline & & $\mathrm{cm}$ & \multicolumn{5}{|c|}{$u \mathrm{~mol} \mathrm{~g}^{-1}$} \\
\hline \multicolumn{8}{|c|}{ Narrow Wetland } \\
\hline 2 & $\begin{array}{l}\text { Oi } \\
\text { M1 } \\
\text { M2 } \\
\text { M3 } \\
\end{array}$ & $\begin{array}{c}0-5 \\
5--15 \\
15--35 \\
35--65 \\
\end{array}$ & $\begin{array}{l}77.8 \\
35.3 \\
31.1 \\
24.5 \\
\end{array}$ & $\begin{array}{l}0.1 \\
0.3 \\
0.4 \\
0.2 \\
\end{array}$ & $\begin{array}{c}0.5 \\
\text { BDL*}^{*} \\
0.2 \\
0.2 \\
\end{array}$ & $\begin{array}{c}\text { BDL } \\
6.2 \\
2.6 \\
2.6 \\
\end{array}$ & $\begin{array}{l}77.2 \\
28.9 \\
27.8 \\
21.5 \\
\end{array}$ \\
\hline 4 & $\begin{array}{l}\text { Oi } \\
\text { Oe } \\
\text { Oe } \\
\text { M1 } \\
\text { M2 } \\
\text { M3 }\end{array}$ & $\begin{array}{c}0--6 \\
6--15 \\
15--23 \\
23--33 \\
33--53 \\
53--83\end{array}$ & $\begin{array}{c}489.4 \\
788.1 \\
910.8 \\
167.0 \\
127.2 \\
99.4\end{array}$ & $\begin{array}{l}0.7 \\
1.0 \\
0.8 \\
1.2 \\
0.4 \\
1.4\end{array}$ & $\begin{array}{c}1.3 \\
7.2 \\
3.4 \\
\mathrm{BDL} \\
\mathrm{BDL} \\
\mathrm{BDL}\end{array}$ & $\begin{array}{l}81.7 \\
11.4 \\
96.7 \\
72.9 \\
66.3 \\
72.8 \\
\end{array}$ & $\begin{array}{c}405.7 \\
768.5 \\
810.0 \\
92.9 \\
60.6 \\
25.2 \\
\end{array}$ \\
\hline 6 & $\begin{array}{l}\text { Oi } \\
\text { M1 } \\
\text { M2 } \\
\text { M3 }\end{array}$ & $\begin{array}{c}0--42 \\
42--52 \\
52--72 \\
72--102 \\
\end{array}$ & $\begin{array}{l}250.1 \\
358.5 \\
128.9 \\
106.6 \\
\end{array}$ & $\begin{array}{l}0.3 \\
4.5 \\
0.2 \\
0.2\end{array}$ & $\begin{array}{c}\text { BDL } \\
2.6 \\
0.6 \\
\text { BDL }\end{array}$ & $\begin{array}{c}11.5 \\
150.2 \\
27.1 \\
69.0 \\
\end{array}$ & $\begin{array}{c}238.3 \\
201.3 \\
100.9 \\
37.5 \\
\end{array}$ \\
\hline \multicolumn{8}{|c|}{ Iron Pond } \\
\hline 1 & $\begin{array}{l}\text { Oi } \\
\text { Oe } \\
\text { M1 } \\
\text { M2 } \\
\text { M3 } \\
\end{array}$ & $\begin{array}{c}0--7 \\
7--9 \\
9--19 \\
19--39 \\
39--69 \\
\end{array}$ & $\begin{array}{l}54.1 \\
36.5 \\
32.5 \\
29.9 \\
36.4 \\
\end{array}$ & $\begin{array}{c}0.4 \\
0.1 \\
0.1 \\
\text { BDL } \\
0.1 \\
\end{array}$ & $\begin{array}{l}\text { BDL } \\
\text { BDL } \\
\text { BDL } \\
\text { BDL } \\
\text { BDL }\end{array}$ & $\begin{array}{c}4.0 \\
\text { BDL } \\
0.5 \\
0.4 \\
4.4 \\
\end{array}$ & $\begin{array}{l}49.6 \\
36.4 \\
31.9 \\
29.4 \\
31.9 \\
\end{array}$ \\
\hline 2 & $\begin{array}{l}\text { Oi } \\
\text { M1 } \\
\text { M2 } \\
\text { M3 } \\
\text { M4 } \\
\end{array}$ & $\begin{array}{c}0--23 \\
23--45 \\
45-55 \\
55-75 \\
75--105 \\
\end{array}$ & $\begin{array}{c}249.1 \\
207.4 \\
25.7 \\
10.3 \\
15.9 \\
\end{array}$ & $\begin{array}{c}16.6 \\
0.1 \\
\text { BDL } \\
\text { BDL } \\
\text { BDL }\end{array}$ & $\begin{array}{c}\text { BDL } \\
22.7 \\
\text { BDL } \\
\text { BDL } \\
0.1 \\
\end{array}$ & $\begin{array}{c}199.7 \\
31.8 \\
2.8 \\
1.3 \\
1.9 \\
\end{array}$ & $\begin{array}{c}32.7 \\
152.9 \\
22.8 \\
9.0 \\
13.8 \\
\end{array}$ \\
\hline 3 & $\begin{array}{l}\text { M/Oi } \\
\text { M1 } \\
\text { M2 } \\
\text { M3 }\end{array}$ & $\begin{array}{c}0--22 \\
22--32 \\
32--52 \\
52--82\end{array}$ & $\begin{array}{c}512.8 \\
82.7 \\
25.3 \\
33.9\end{array}$ & $\begin{array}{c}159.5 \\
5.8 \\
\text { BDL } \\
0.1\end{array}$ & $\begin{array}{l}1.2 \\
0.6 \\
0.1 \\
0.3\end{array}$ & $\begin{array}{l}8.4 \\
4.6 \\
4.8 \\
3.9\end{array}$ & $\begin{array}{l}343.8 \\
71.7 \\
20.4 \\
29.6\end{array}$ \\
\hline 4 & $\begin{array}{l}\text { Oi } \\
\text { M1 } \\
\text { M2 } \\
\text { M3 } \\
\text { M4 } \\
\end{array}$ & $\begin{array}{c}0--21 \\
21--32 \\
32--42 \\
42--62 \\
62--92 \\
\end{array}$ & $\begin{array}{l}138.9 \\
84.2 \\
41.6 \\
20.9 \\
23.1 \\
\end{array}$ & $\begin{array}{c}23.6 \\
0.1 \\
2.8 \\
4.8 \\
2.9 \\
\end{array}$ & $\begin{array}{c}\text { BDL } \\
0.4 \\
\text { BDL } \\
\text { BDL } \\
\text { BDL }\end{array}$ & $\begin{array}{c}22.9 \\
78.5 \\
3.3 \\
1.4 \\
2.0 \\
\end{array}$ & $\begin{array}{c}92.5 \\
5.3 \\
35.4 \\
14.7 \\
18.1 \\
\end{array}$ \\
\hline 5 & $\begin{array}{l}\text { Oi } \\
\text { M1 } \\
\text { M2 } \\
\text { M3 } \\
\text { M4 } \\
\text { M5 } \\
\text { M6 }\end{array}$ & $\begin{array}{c}0--18 \\
18--31 \\
31--50 \\
50--64 \\
64--74 \\
74--94 \\
94--124\end{array}$ & $\begin{array}{c}230.5 \\
280.7 \\
131.0 \\
127.7 \\
20.1 \\
20.1 \\
32.0\end{array}$ & $\begin{array}{c}111.5 \\
0.3 \\
0.4 \\
1.0 \\
0.5 \\
1.9 \\
1.4\end{array}$ & $\begin{array}{c}\text { BDL } \\
13.7 \\
0.2 \\
3.7 \\
\text { BDL } \\
\text { BDL } \\
0.6\end{array}$ & $\begin{array}{c}1.5 \\
32.4 \\
3.9 \\
19.9 \\
3.6 \\
1.6 \\
1.6\end{array}$ & $\begin{array}{c}117.5 \\
234.2 \\
126.6 \\
103.1 \\
16.1 \\
16.7 \\
28.5\end{array}$ \\
\hline
\end{tabular}


124

\begin{tabular}{|c|c|c|c|c|c|c|c|}
\hline \multirow[t]{2}{*}{ Transect-Stop } & \multirow[t]{2}{*}{ Soil Type } & Sample Depth & $S$ & $\mathrm{SO}_{4}$ & AVS & CRS & OS \\
\hline & & $\mathrm{cm}$ & \multicolumn{5}{|c|}{$u m o l g^{-1}$} \\
\hline \multicolumn{8}{|c|}{ Railroad Grade } \\
\hline $1-1$ & $\begin{array}{l}\text { Oi } \\
\text { Oe } \\
\text { Oa } \\
\text { M1 } \\
\text { M2 } \\
\end{array}$ & $\begin{array}{c}0--18 \\
18--25 \\
25--35 \\
35--55 \\
55--85 \\
\end{array}$ & $\begin{array}{c}163.6 \\
225.7 \\
71.5 \\
35.5 \\
18.9 \\
\end{array}$ & $\begin{array}{c}1.3 \\
\mathrm{BDL} \\
0.3 \\
0.3 \\
0.7 \\
\end{array}$ & $\begin{array}{l}\text { BDL } \\
\text { BDL } \\
\text { BDL } \\
\text { BDL } \\
\text { BDL }\end{array}$ & $\begin{array}{c}21.6 \\
2.6 \\
1.0 \\
0.8 \\
4.7 \\
\end{array}$ & $\begin{array}{c}140.7 \\
223.0 \\
70.1 \\
34.4 \\
13.5 \\
\end{array}$ \\
\hline $1--2$ & $\begin{array}{c}\mathrm{Oi} \\
\mathrm{Oe} \\
\mathrm{Oa} 1 \\
\mathrm{Oa} 2 \\
\mathrm{M} 1 \\
\mathrm{M} 2 \\
\end{array}$ & $\begin{array}{c}0--33 \\
33--40 \\
40--45 \\
45-55 \\
55--75 \\
75--82\end{array}$ & $\begin{array}{c}183.3 \\
222.9 \\
177.9 \\
125.7 \\
53.1 \\
58.4 \\
\end{array}$ & $\begin{array}{l}7.3 \\
0.1 \\
0.4 \\
0.2 \\
0.8 \\
1.0 \\
\end{array}$ & $\begin{array}{l}\text { BDL } \\
\text { BDL } \\
\text { BDL } \\
\text { BDL } \\
\text { BDL } \\
\text { BDL }\end{array}$ & $\begin{array}{c}1.2 \\
2.0 \\
\text { BDL } \\
2.0 \\
1.6 \\
5.8 \\
\end{array}$ & $\begin{array}{c}174.7 \\
220.8 \\
177.5 \\
123.5 \\
50.7 \\
51.7 \\
\end{array}$ \\
\hline $1--3$ & $\begin{array}{l}\text { Oi } \\
\text { Oe } \\
\text { M1 } \\
\text { M2 } \\
\text { Oa } \\
\text { M3 } \\
\end{array}$ & $\begin{array}{c}0--13 \\
13--23 \\
23--33 \\
33--53 \\
42--47 \\
53--83 \\
\end{array}$ & $\begin{array}{c}256.4 \\
322.7 \\
38.4 \\
59.4 \\
106.0 \\
41.9 \\
\end{array}$ & $\begin{array}{c}0.2 \\
\mathrm{BDL} \\
0.3 \\
0.2 \\
\mathrm{BDL} \\
0.2 \\
\end{array}$ & $\begin{array}{l}\text { BDL } \\
B D L \\
B D L \\
B D L \\
B D L \\
B D L\end{array}$ & $\begin{array}{c}46.2 \\
38.8 \\
13.8 \\
9.5 \\
44.9 \\
2.1 \\
\end{array}$ & $\begin{array}{c}205.8 \\
283.9 \\
24.0 \\
49.0 \\
61.2 \\
39.6 \\
\end{array}$ \\
\hline $1--4$ & $\begin{array}{l}\text { Oi } \\
\text { Oe } \\
\text { M1 } \\
\text { M2 } \\
\text { M3 } \\
\text { M4 } \\
\end{array}$ & $\begin{array}{c}0--13 \\
13--17 \\
17--27 \\
27--47 \\
47--77 \\
40--50 \\
\end{array}$ & $\begin{array}{c}335.6 \\
326.7 \\
92.8 \\
90.9 \\
94.0 \\
105.4 \\
\end{array}$ & $\begin{array}{c}4.4 \\
\text { BDL } \\
0.1 \\
0.4 \\
0.6 \\
10.1 \\
\end{array}$ & $\begin{array}{c}121.4 \\
12.0 \\
0.6 \\
\text { BDL } \\
\text { BDL } \\
6.0 \\
\end{array}$ & $\begin{array}{c}215.1 \\
146.9 \\
7.6 \\
54.5 \\
16.6 \\
47.7 \\
\end{array}$ & $\begin{array}{c}-5.2 \\
167.8 \\
84.4 \\
35.9 \\
76.8 \\
41.6 \\
\end{array}$ \\
\hline $2--1$ & $\begin{array}{l}\text { Oi } \\
\text { Oe } \\
\text { M1 } \\
\text { M2 } \\
\text { M3 } \\
\text { M4 } \\
\text { M5 } \\
\text { Oe } \\
\end{array}$ & $\begin{array}{c}0--7 \\
7--18 \\
18--28 \\
28--38 \\
38--58 \\
58--88 \\
88--124 \\
66-82 \\
\end{array}$ & $\begin{array}{c}163.8 \\
857.0 \\
357.1 \\
86.0 \\
161.0 \\
69.3 \\
14.0 \\
253.6 \\
\end{array}$ & $\begin{array}{c}0.2 \\
\text { BDL } \\
\text { BDL } \\
0.6 \\
0.1 \\
0.2 \\
0.4 \\
0.6 \\
\end{array}$ & $\begin{array}{c}0.1 \\
428.7 \\
116.8 \\
0.4 \\
\text { BDL } \\
\text { BDL } \\
\text { BDL } \\
\text { BDL }\end{array}$ & $\begin{array}{c}24.3 \\
415.7 \\
148.8 \\
12.6 \\
13.3 \\
16.0 \\
1.4 \\
0.8 \\
\end{array}$ & $\begin{array}{c}139.2 \\
12.5 \\
91.5 \\
72.5 \\
147.7 \\
53.1 \\
12.1 \\
252.2 \\
\end{array}$ \\
\hline $2--2$ & $\begin{array}{l}\text { Oi } \\
\text { Oe } \\
\text { Oa } \\
\text { Oa } \\
\text { M1 } \\
\text { M2 } \\
\text { M3 } \\
\end{array}$ & $\begin{array}{c}0--9 \\
9--16 \\
16--24 \\
24--34 \\
34--54 \\
54--84 \\
84--124 \\
\end{array}$ & $\begin{array}{c}111.8 \\
119.8 \\
97.8 \\
67.2 \\
55.4 \\
665.8 \\
166.5 \\
\end{array}$ & $\begin{array}{c}0.9 \\
\mathrm{BDL} \\
\mathrm{BDL} \\
1.3 \\
\mathrm{BDL} \\
7.0 \\
1.0 \\
\end{array}$ & $\begin{array}{l}\text { BDL } \\
\text { BDL } \\
\text { BDL } \\
\text { BDL } \\
\text { BDL } \\
\text { BDL } \\
\text { BDL }\end{array}$ & $\begin{array}{c}26.5 \\
11.0 \\
6.0 \\
1.1 \\
5.2 \\
3.1 \\
1.4 \\
\end{array}$ & $\begin{array}{c}84.3 \\
108.9 \\
91.8 \\
64.8 \\
50.2 \\
655.7 \\
164.0 \\
\end{array}$ \\
\hline $2--3$ & $\begin{array}{c}\text { Oi } \\
\text { Oe } \\
\text { Oa } \\
\text { M1 } \\
\text { M2 } \\
\end{array}$ & $\begin{array}{r}0--20 \\
20--28 \\
28--38 \\
38--58 \\
58--71 \\
\end{array}$ & $\begin{array}{c}83.4 \\
104.7 \\
46.4 \\
38.1 \\
42.3 \\
\end{array}$ & $\begin{array}{c}2.9 \\
\text { BDL } \\
\text { BDL } \\
\text { BDL } \\
\text { BDL }\end{array}$ & $\begin{array}{l}\text { BDL } \\
\text { BDL } \\
\text { BDL } \\
\text { BDL } \\
\text { BDL }\end{array}$ & $\begin{array}{l}2.2 \\
2.7 \\
0.6 \\
0.7 \\
0.9 \\
\end{array}$ & $\begin{array}{c}78.3 \\
102.0 \\
45.8 \\
37.4 \\
41.4 \\
\end{array}$ \\
\hline
\end{tabular}




\begin{tabular}{|c|c|c|c|c|c|c|c|}
\hline \multirow[t]{2}{*}{ Stop } & \multirow[t]{2}{*}{ Soil Type } & Sample Depth & $S$ & $\mathrm{SO}_{4}$ & AVS & CRS & OS \\
\hline & & $\mathrm{cm}$ & \multicolumn{5}{|c|}{$u \mathrm{~mol} \mathrm{~g}^{-1}$} \\
\hline \multicolumn{8}{|c|}{ Alder Thicket } \\
\hline 1 & $\begin{array}{l}\text { Oe } \\
\text { Oa1 } \\
\text { Oa2 } \\
\text { M1 } \\
\text { M2 } \\
\text { M3 } \\
\end{array}$ & $\begin{array}{c}0--3 \\
3--9 \\
9--19 \\
19-39 \\
39--69 \\
69--109 \\
\end{array}$ & $\begin{array}{c}149.6 \\
259.6 \\
149.8 \\
39.0 \\
53.9 \\
45.7 \\
\end{array}$ & $\begin{array}{c}\mathrm{BDL} \\
\mathrm{BDL} \\
0.1 \\
\mathrm{BDL} \\
0.1 \\
0.5 \\
\end{array}$ & $\begin{array}{c}\text { BDL } \\
0.2 \\
\text { BDL } \\
\text { BDL } \\
\text { BDL } \\
\text { BDL } \\
\end{array}$ & $\begin{array}{c}6.5 \\
18.4 \\
4.4 \\
1.8 \\
2.6 \\
3.4 \\
\end{array}$ & $\begin{array}{l}143.1 \\
241.0 \\
145.3 \\
37.1 \\
51.1 \\
41.8 \\
\end{array}$ \\
\hline 3 & $\begin{array}{l}\text { Oe } \\
\text { Oa } \\
\text { Oa } \\
\text { M1 } \\
\text { M2 } \\
\text { M3 }\end{array}$ & $\begin{array}{c}0--3 \\
03--25 \\
25--35 \\
35--55 \\
55-85 \\
85--125 \\
\end{array}$ & $\begin{array}{c}165.0 \\
357.3 \\
120.3 \\
40.2 \\
40.3 \\
114.4 \\
\end{array}$ & $\begin{array}{c}\text { BDL } \\
\text { BDL } \\
B D L \\
B D L \\
0.2 \\
1.0 \\
\end{array}$ & $\begin{array}{c}\text { BDL } \\
3.4 \\
\text { BDL } \\
\text { BDL } \\
\text { BDL } \\
\text { BDL }\end{array}$ & $\begin{array}{c}23.7 \\
136.1 \\
26.0 \\
1.4 \\
1.9 \\
10.8 \\
\end{array}$ & $\begin{array}{c}141.3 \\
217.8 \\
94.4 \\
38.8 \\
38.2 \\
102.5 \\
\end{array}$ \\
\hline \multicolumn{8}{|c|}{ Forested Wetland } \\
\hline 1 & $\begin{array}{l}\text { Oi } \\
\text { M1 } \\
\text { M2 } \\
\text { M3 } \\
\text { M4 } \\
\text { M5 } \\
\end{array}$ & $\begin{array}{c}0--7 \\
7--11 \\
11--21 \\
21--41 \\
41--71 \\
71--111 \\
\end{array}$ & $\begin{array}{l}111.9 \\
26.3 \\
11.0 \\
13.9 \\
21.8 \\
17.8 \\
\end{array}$ & $\begin{array}{c}1.0 \\
\text { BDL } \\
\text { BDL } \\
0.1 \\
0.2 \\
0.3 \\
\end{array}$ & $\begin{array}{l}\text { BDL } \\
\text { BDL } \\
\text { BDL } \\
\text { BDL } \\
\text { BDL } \\
\text { BDL } \\
\end{array}$ & $\begin{array}{c}1.5 \\
0.4 \\
1.0 \\
\text { BDL } \\
0.1 \\
0.0 \\
\end{array}$ & $\begin{array}{l}109.5 \\
25.8 \\
10.1 \\
13.8 \\
21.5 \\
17.5 \\
\end{array}$ \\
\hline 2 & $\begin{array}{l}\text { Oe } \\
\text { Oa } \\
\text { M1 } \\
\text { M2 } \\
\text { M3 } \\
\text { M4 } \\
\end{array}$ & $\begin{array}{c}0--4 \\
4--14 \\
14--34 \\
34--64 \\
64--104 \\
104--150 \\
\end{array}$ & $\begin{array}{c}110.1 \\
84.0 \\
23.3 \\
8.4 \\
11.5 \\
12.8 \\
\end{array}$ & $\begin{array}{l}0.3 \\
0.1 \\
0.1 \\
0.2 \\
0.8 \\
0.6 \\
\end{array}$ & $\begin{array}{l}\text { BDL } \\
\text { BDL } \\
\text { BDL } \\
\text { BDL } \\
\text { BDL } \\
\text { BDL }\end{array}$ & $\begin{array}{r}5.0 \\
0.8 \\
0.5 \\
1.2 \\
0.3 \\
\text { BDL } \\
\end{array}$ & $\begin{array}{c}104.8 \\
83.1 \\
22.7 \\
6.9 \\
10.5 \\
12.3 \\
\end{array}$ \\
\hline \multicolumn{8}{|c|}{ Scrub Shrub } \\
\hline 1 & $\begin{array}{l}\text { Oa } \\
\text { M1 } \\
\text { M2 } \\
\text { M3 } \\
\text { M4 } \\
\end{array}$ & $\begin{array}{c}0--4 \\
4--14 \\
14--34 \\
34--64 \\
64--104 \\
\end{array}$ & $\begin{array}{c}74.4 \\
20.6 \\
12.2 \\
5.9 \\
7.2 \\
\end{array}$ & $\begin{array}{c}0.1 \\
\text { BDL } \\
\text { BDL } \\
0.5 \\
0.4 \\
\end{array}$ & $\begin{array}{l}\text { BDL } \\
\text { BDL } \\
\text { BDL } \\
\text { BDL } \\
\text { BDL }\end{array}$ & $\begin{array}{l}1.9 \\
0.5 \\
0.2 \\
0.1 \\
0.1 \\
\end{array}$ & $\begin{array}{c}72.4 \\
20.1 \\
12.1 \\
5.2 \\
6.8 \\
\end{array}$ \\
\hline 2 & $\begin{array}{l}\text { Oa } \\
\text { M1 } \\
\text { M2 } \\
\text { M3 } \\
\text { M4 }\end{array}$ & $\begin{array}{c}0--9 \\
9--19 \\
19--39 \\
39--69 \\
69--109\end{array}$ & $\begin{array}{c}91.5 \\
27.4 \\
8.4 \\
4.9 \\
5.9\end{array}$ & $\begin{array}{c}0.3 \\
\mathrm{BDL} \\
\mathrm{BDL} \\
0.2 \\
0.1\end{array}$ & $\begin{array}{l}\text { BDL } \\
\text { BDL } \\
\text { BDL } \\
\text { BDL } \\
\text { BDL }\end{array}$ & $\begin{array}{c}2.5 \\
2.6 \\
0.1 \\
\text { BDL } \\
\text { BDL }\end{array}$ & $\begin{array}{c}88.6 \\
24.8 \\
8.3 \\
4.7 \\
5.7\end{array}$ \\
\hline
\end{tabular}




\begin{tabular}{|c|c|c|c|c|c|c|c|}
\hline \multirow[t]{2}{*}{ Transect-Stop } & \multirow[t]{2}{*}{ Soil Type } & Sample Depth & $S$ & $\mathrm{SO}_{4}$ & AVS & CRS & OS \\
\hline & & $\mathrm{cm}$ & \multicolumn{5}{|c|}{ 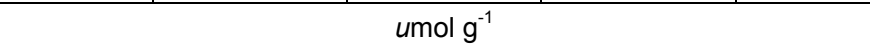 } \\
\hline \multicolumn{8}{|c|}{ Fen-Marsh } \\
\hline $1--2$ & $\begin{array}{l}\mathrm{Oi} \\
\mathrm{Oe} \\
\mathrm{Oa} \\
\mathrm{Oa} \\
\mathrm{Oa} \\
\mathrm{M} 1 \\
\mathrm{M} 2 \\
\mathrm{M} 3 \\
\end{array}$ & $\begin{array}{c}0--8 \\
8--16 \\
16--41 \\
41--48 \\
48--58 \\
58--78 \\
78--108 \\
108--148 \\
\end{array}$ & $\begin{array}{c}199.5 \\
718.3 \\
412.2 \\
258.7 \\
170.9 \\
29.9 \\
16.7 \\
21.7 \\
\end{array}$ & $\begin{array}{c}\text { BDL } \\
25.1 \\
0.2 \\
3.0 \\
0.1 \\
\text { BDL } \\
\text { BDL } \\
0.1 \\
\end{array}$ & $\begin{array}{c}\text { BDL } \\
111.1 \\
0.3 \\
0.2 \\
\text { BDL } \\
\text { BDL } \\
\text { BDL } \\
\text { BDL } \\
\end{array}$ & $\begin{array}{c}21.2 \\
321.2 \\
85.6 \\
60.4 \\
27.1 \\
0.9 \\
0.8 \\
0.3 \\
\end{array}$ & $\begin{array}{c}178.3 \\
260.9 \\
326.2 \\
195.1 \\
143.8 \\
28.9 \\
15.8 \\
21.3 \\
\end{array}$ \\
\hline $2-1$ & $\begin{array}{l}\mathrm{Oi} \\
\mathrm{Oe} \\
\mathrm{Oa} \\
\mathrm{Oa} \\
\mathrm{Oa}\end{array}$ & $\begin{array}{c}0--4 \\
4--42 \\
42--52 \\
52--72 \\
72--102 \\
\end{array}$ & $\begin{array}{l}225.0 \\
371.6 \\
381.5 \\
304.7 \\
151.3 \\
\end{array}$ & $\begin{array}{c}72.8 \\
6.8 \\
7.9 \\
2.7 \\
\text { BDL } \\
\end{array}$ & $\begin{array}{c}0.2 \\
0.6 \\
0.5 \\
0.4 \\
\text { BDL }\end{array}$ & $\begin{array}{l}13.7 \\
79.1 \\
81.1 \\
77.1 \\
28.1 \\
\end{array}$ & $\begin{array}{l}138.3 \\
285.2 \\
292.1 \\
224.5 \\
123.2 \\
\end{array}$ \\
\hline $2--3$ & $\begin{array}{l}\mathrm{Oe} \\
\mathrm{Oa} \\
\mathrm{Oa} \\
\mathrm{Oa} \\
\mathrm{Oa} \\
\mathrm{Oa}\end{array}$ & $\begin{array}{c}0--21 \\
21-31 \\
31-41 \\
41-61 \\
61-91 \\
91-120+\end{array}$ & $\begin{array}{l}202.5 \\
253.8 \\
127.6 \\
129.5 \\
119.0 \\
100.0\end{array}$ & $\begin{array}{l}1.4 \\
0.4 \\
0.3 \\
0.5 \\
0.4 \\
0.4\end{array}$ & $\begin{array}{c}\text { BDL } \\
0.6 \\
\text { BDL } \\
\text { BDL } \\
\text { BDL } \\
\text { BDL }\end{array}$ & $\begin{array}{l}7.4 \\
7.9 \\
4.6 \\
2.7 \\
1.7 \\
2.2 \\
\end{array}$ & $\begin{array}{c}193.8 \\
244.9 \\
122.6 \\
126.3 \\
116.9 \\
97.4\end{array}$ \\
\hline $2--4$ & $\begin{array}{l}\mathrm{Oi} \\
\mathrm{Oe} \\
\mathrm{Oa} \\
\mathrm{Oa} \\
\mathrm{Oa} \\
\mathrm{Oa} \\
\mathrm{M} 1\end{array}$ & $\begin{array}{c}0--23 \\
23--33 \\
33--43 \\
43--53 \\
53--73 \\
73--103 \\
103--143\end{array}$ & $\begin{array}{c}145.5 \\
204.3 \\
141.9 \\
102.6 \\
99.8 \\
92.0 \\
3.0\end{array}$ & $\begin{array}{l}1.2 \\
1.8 \\
0.5 \\
0.5 \\
0.3 \\
0.4 \\
0.4\end{array}$ & $\begin{array}{l}\text { BDL } \\
\text { BDL } \\
\text { BDL } \\
\text { BDL } \\
\text { BDL } \\
\text { BDL } \\
\text { BDL }\end{array}$ & $\begin{array}{l}2.1 \\
5.4 \\
6.9 \\
0.6 \\
0.4 \\
0.7 \\
0.2\end{array}$ & $\begin{array}{c}142.3 \\
197.1 \\
134.5 \\
101.5 \\
99.1 \\
90.8 \\
2.4\end{array}$ \\
\hline
\end{tabular}

* BDL - Below Detection Limit 
Table 13. Percent of total sulfur that each sulfur fraction constitutes in all wetland soils. Sulfate $=\mathrm{SO}_{4}$, acid volatile sulfides=AVS, chromium reducible sulfides $=\mathrm{CRS}$, and organic sulfur=OS.

\begin{tabular}{|c|c|c|c|c|c|c|}
\hline \multirow[t]{2}{*}{ Stop } & \multirow[t]{2}{*}{ Soil Type } & Sample Depth & $\mathrm{SO}_{4}$ & AVS & CRS & OS \\
\hline & & $\mathrm{cm}$ & \multicolumn{4}{|c|}{$\%$ of total sulfur } \\
\hline \multicolumn{7}{|c|}{ Narrow Wetland } \\
\hline 2 & $\begin{array}{l}\text { Oi } \\
\text { M1 } \\
\text { M2 } \\
\text { M3 } \\
\end{array}$ & $\begin{array}{c}0-5 \\
5--15 \\
15--35 \\
35--65 \\
\end{array}$ & $\begin{array}{l}0.2 \\
0.7 \\
1.4 \\
1.0 \\
\end{array}$ & $\begin{array}{l}0.7 \\
0.0 \\
0.8 \\
0.9 \\
\end{array}$ & $\begin{array}{c}0.0 \\
17.5 \\
8.2 \\
10.7 \\
\end{array}$ & $\begin{array}{l}99.2 \\
81.7 \\
89.6 \\
87.4 \\
\end{array}$ \\
\hline 4 & $\begin{array}{l}\text { Oi } \\
\text { Oe } \\
\text { Oe } \\
\text { M1 } \\
\text { M2 } \\
\text { M3 }\end{array}$ & $\begin{array}{c}0--6 \\
6--15 \\
15--23 \\
23--33 \\
33--53 \\
53--83 \\
\end{array}$ & $\begin{array}{l}0.1 \\
0.1 \\
0.1 \\
0.7 \\
0.3 \\
1.4 \\
\end{array}$ & $\begin{array}{l}0.3 \\
0.9 \\
0.4 \\
0.0 \\
0.0 \\
0.0 \\
\end{array}$ & \begin{tabular}{c|}
16.7 \\
1.4 \\
10.6 \\
43.7 \\
52.1 \\
73.3 \\
\end{tabular} & $\begin{array}{l}82.9 \\
97.5 \\
88.9 \\
55.6 \\
47.6 \\
25.4 \\
\end{array}$ \\
\hline 6 & $\begin{array}{l}\mathrm{Oi} \\
\mathrm{M} 1 \\
\mathrm{M} 2 \\
\mathrm{M} 3 \\
\end{array}$ & $\begin{array}{c}0--42 \\
42--52 \\
52--72 \\
72--102 \\
\end{array}$ & $\begin{array}{l}0.1 \\
1.3 \\
0.1 \\
0.2\end{array}$ & $\begin{array}{l}0.0 \\
0.7 \\
0.5 \\
0.0\end{array}$ & $\begin{array}{c}4.6 \\
41.9 \\
21.0 \\
64.7 \\
\end{array}$ & $\begin{array}{l}95.3 \\
56.1 \\
78.3 \\
35.2 \\
\end{array}$ \\
\hline \multicolumn{7}{|c|}{ Iron Pond } \\
\hline 1 & $\begin{array}{l}\text { Oi } \\
\text { Oe } \\
\text { M1 } \\
\text { M2 } \\
\text { M3 } \\
\end{array}$ & $\begin{array}{c}0--7 \\
7--9 \\
9--19 \\
19--39 \\
39--69 \\
\end{array}$ & $\begin{array}{l}0.8 \\
0.3 \\
0.4 \\
0.1 \\
0.3 \\
\end{array}$ & $\begin{array}{l}0.0 \\
0.0 \\
0.0 \\
0.0 \\
0.0 \\
\end{array}$ & $\begin{array}{c}7.5 \\
0.0 \\
1.4 \\
1.5 \\
12.0 \\
\end{array}$ & $\begin{array}{l}91.8 \\
99.7 \\
98.2 \\
98.4 \\
87.7 \\
\end{array}$ \\
\hline 2 & $\begin{array}{l}\text { Oi } \\
\text { M1 } \\
\text { M2 } \\
\text { M3 } \\
\text { M4 } \\
\end{array}$ & $\begin{array}{c}0--23 \\
23--45 \\
45-55 \\
55-75 \\
75--105\end{array}$ & $\begin{array}{l}6.7 \\
0.0 \\
0.1 \\
0.2 \\
0.3\end{array}$ & $\begin{array}{c}0.0 \\
10.9 \\
0.0 \\
0.2 \\
0.8 \\
\end{array}$ & $\begin{array}{l}80.2 \\
15.3 \\
11.0 \\
12.3 \\
11.9 \\
\end{array}$ & $\begin{array}{l}13.1 \\
73.7 \\
88.9 \\
87.3 \\
87.0\end{array}$ \\
\hline 3 & $\begin{array}{l}\text { M/Oi } \\
\text { M1 } \\
\text { M2 } \\
\text { M3 }\end{array}$ & $\begin{array}{c}0--22 \\
22--32 \\
32--52 \\
52--82 \\
\end{array}$ & $\begin{array}{c}31.1 \\
7.0 \\
0.1 \\
0.2 \\
\end{array}$ & $\begin{array}{l}0.2 \\
0.7 \\
0.4 \\
1.0 \\
\end{array}$ & $\begin{array}{c}1.6 \\
5.6 \\
19.0 \\
11.5 \\
\end{array}$ & $\begin{array}{l}67.0 \\
86.7 \\
80.6 \\
87.3 \\
\end{array}$ \\
\hline 4 & $\begin{array}{l}\text { Oi } \\
\text { M1 } \\
\text { M2 } \\
\text { M3 } \\
\text { M4 } \\
\end{array}$ & $\begin{array}{c}0--21 \\
21--32 \\
32--42 \\
42--62 \\
62--92 \\
\end{array}$ & \begin{tabular}{c|}
17.0 \\
0.1 \\
6.8 \\
23.1 \\
12.7 \\
\end{tabular} & $\begin{array}{l}0.0 \\
0.4 \\
0.0 \\
0.0 \\
0.0 \\
\end{array}$ & $\begin{array}{c}16.4 \\
93.2 \\
8.0 \\
6.5 \\
8.8 \\
\end{array}$ & $\begin{array}{c}66.6 \\
6.3 \\
85.2 \\
70.3 \\
78.5 \\
\end{array}$ \\
\hline 5 & $\begin{array}{l}\text { Oi } \\
\text { M1 } \\
\text { M2 } \\
\text { M3 } \\
\text { M4 } \\
\text { M5 } \\
\text { M6 }\end{array}$ & $\begin{array}{c}0--18 \\
18--31 \\
31--50 \\
50--64 \\
64--74 \\
74--94 \\
94--124\end{array}$ & $\begin{array}{c}48.4 \\
0.1 \\
0.3 \\
0.8 \\
2.4 \\
9.3 \\
4.4\end{array}$ & $\begin{array}{l}0.0 \\
4.9 \\
0.2 \\
2.9 \\
0.0 \\
0.0 \\
1.8\end{array}$ & $\begin{array}{c}0.6 \\
11.6 \\
2.9 \\
15.6 \\
17.9 \\
8.0 \\
4.9\end{array}$ & $\begin{array}{l}51.0 \\
83.4 \\
96.6 \\
80.7 \\
79.8 \\
82.7 \\
88.9\end{array}$ \\
\hline
\end{tabular}




\begin{tabular}{|c|c|c|c|c|c|c|}
\hline \multirow[t]{2}{*}{ Transect-Stop } & \multirow[t]{2}{*}{ Soil Type } & Sample Depth & $\mathrm{SO}_{4}$ & AVS & CRS & OS \\
\hline & & $\mathrm{cm}$ & \multicolumn{4}{|c|}{$\%$ of total sulfur } \\
\hline \multicolumn{7}{|c|}{ Railroad Grade } \\
\hline $1--1$ & $\begin{array}{l}\mathrm{Oi} \\
\mathrm{Oe} \\
\mathrm{Oa} \\
\mathrm{M} 1 \\
\mathrm{M} 2 \\
\end{array}$ & $\begin{array}{c}0--18 \\
18--25 \\
25--35 \\
35--55 \\
55--85 \\
\end{array}$ & $\begin{array}{l}0.8 \\
0.0 \\
0.5 \\
0.9 \\
3.9 \\
\end{array}$ & $\begin{array}{l}0.0 \\
0.0 \\
0.0 \\
0.0 \\
0.0 \\
\end{array}$ & $\begin{array}{c}13.2 \\
1.2 \\
1.4 \\
2.2 \\
24.6 \\
\end{array}$ & $\begin{array}{l}86.0 \\
98.8 \\
98.1 \\
96.9 \\
71.5 \\
\end{array}$ \\
\hline $1--2$ & $\begin{array}{c}\text { Oi } \\
\text { Oe } \\
\text { Oa1 } \\
\text { Oa2 } \\
\text { M1 } \\
\text { M2 } \\
\end{array}$ & $\begin{array}{c}0--33 \\
33--40 \\
40--45 \\
45-55 \\
55--75 \\
75--82\end{array}$ & $\begin{array}{l}4.0 \\
0.1 \\
0.2 \\
0.2 \\
1.6 \\
1.6 \\
\end{array}$ & $\begin{array}{l}0.0 \\
0.0 \\
0.0 \\
0.0 \\
0.0 \\
0.0\end{array}$ & $\begin{array}{l}0.7 \\
0.9 \\
0.0 \\
1.6 \\
3.0 \\
9.9\end{array}$ & $\begin{array}{l}95.3 \\
99.0 \\
99.8 \\
98.3 \\
95.4 \\
88.5\end{array}$ \\
\hline $1--3$ & $\begin{array}{l}\text { Oi } \\
\text { Oe } \\
\text { M1 } \\
\text { M2 } \\
\text { Oa } \\
\text { M3 } \\
\end{array}$ & $\begin{array}{c}0--13 \\
13--23 \\
23--33 \\
33--53 \\
42--47 \\
53--83 \\
\end{array}$ & $\begin{array}{l}0.1 \\
0.0 \\
0.7 \\
0.4 \\
0.0 \\
0.4 \\
\end{array}$ & $\begin{array}{l}1.7 \\
0.0 \\
0.8 \\
1.1 \\
0.0 \\
0.0 \\
\end{array}$ & \begin{tabular}{c|}
18.0 \\
12.0 \\
35.9 \\
16.0 \\
42.3 \\
5.1 \\
\end{tabular} & $\begin{array}{l}80.3 \\
88.0 \\
62.6 \\
82.6 \\
57.7 \\
94.5 \\
\end{array}$ \\
\hline $1--4$ & $\begin{array}{l}\text { Oi } \\
\text { Oe } \\
\text { M1 } \\
\text { M2 } \\
\text { M3 } \\
\text { M4 }\end{array}$ & $\begin{array}{c}0--13 \\
13--17 \\
17--27 \\
27--47 \\
47--77 \\
40--50\end{array}$ & $\begin{array}{l}1.3 \\
0.0 \\
0.1 \\
0.4 \\
0.6 \\
9.6\end{array}$ & $\begin{array}{c}36.2 \\
3.7 \\
0.6 \\
0.0 \\
0.0 \\
5.7\end{array}$ & $\begin{array}{c}64.1 \\
45.0 \\
8.2 \\
60.0 \\
17.6 \\
45.2\end{array}$ & $\begin{array}{l}-1.6 \\
51.3 \\
91.0 \\
39.5 \\
81.8 \\
39.5\end{array}$ \\
\hline $2--1$ & $\begin{array}{l}\text { Oi } \\
\text { Oe } \\
\text { M1 } \\
\text { M2 } \\
\text { M3 } \\
\text { M4 } \\
\text { M5 } \\
\text { Oe } \\
\end{array}$ & $\begin{array}{c}0--7 \\
7--18 \\
18--28 \\
28--38 \\
38--58 \\
58--88 \\
88--124 \\
66-82 \\
\end{array}$ & $\begin{array}{l}0.1 \\
0.0 \\
0.0 \\
0.6 \\
0.0 \\
0.2 \\
3.2 \\
0.2 \\
\end{array}$ & $\begin{array}{c}0.0 \\
50.0 \\
32.7 \\
0.5 \\
0.0 \\
0.0 \\
0.0 \\
0.0 \\
\end{array}$ & $\begin{array}{c}14.9 \\
48.5 \\
41.7 \\
14.6 \\
8.3 \\
23.1 \\
10.3 \\
0.3 \\
\end{array}$ & $\begin{array}{c}85.0 \\
1.5 \\
25.6 \\
84.3 \\
91.7 \\
76.6 \\
86.5 \\
99.5 \\
\end{array}$ \\
\hline $2--2$ & $\begin{array}{l}\text { Oi } \\
\text { Oe } \\
\text { Oa } \\
\text { Oa } \\
\text { M1 } \\
\text { M2 } \\
\text { M3 } \\
\end{array}$ & $\begin{array}{c}0--9 \\
9--16 \\
16--24 \\
24--34 \\
34--54 \\
54--84 \\
84--124 \\
\end{array}$ & $\begin{array}{l}0.8 \\
0.0 \\
0.0 \\
1.9 \\
0.0 \\
1.0 \\
0.6 \\
\end{array}$ & $\begin{array}{l}0.0 \\
0.0 \\
0.0 \\
0.0 \\
0.0 \\
0.0 \\
0.0 \\
\end{array}$ & $\begin{array}{c}23.7 \\
9.2 \\
6.1 \\
1.7 \\
9.3 \\
0.5 \\
0.9 \\
\end{array}$ & $\begin{array}{l}75.5 \\
90.8 \\
93.9 \\
96.4 \\
90.7 \\
98.5 \\
98.5 \\
\end{array}$ \\
\hline $2--3$ & $\begin{array}{l}\text { Oi } \\
\text { Oe } \\
\text { Oa } \\
\text { M1 } \\
\text { M2 }\end{array}$ & $\begin{array}{r}0--20 \\
20--28 \\
28--38 \\
38--58 \\
58--71\end{array}$ & $\begin{array}{l}3.5 \\
0.0 \\
0.0 \\
0.0 \\
0.0\end{array}$ & $\begin{array}{l}0.0 \\
0.0 \\
0.0 \\
0.0 \\
0.0\end{array}$ & $\begin{array}{l}2.7 \\
2.6 \\
1.3 \\
1.8 \\
2.2\end{array}$ & $\begin{array}{l}93.9 \\
97.4 \\
98.7 \\
98.2 \\
97.8\end{array}$ \\
\hline
\end{tabular}




\begin{tabular}{|c|c|c|c|c|c|c|}
\hline \multirow[t]{2}{*}{ Stop } & \multirow[t]{2}{*}{ Soil Type } & Sample Depth & $\mathrm{SO}_{4}$ & AVS & CRS & OS \\
\hline & & $\mathrm{cm}$ & \multicolumn{4}{|c|}{$\%$ of total sulfur } \\
\hline \multicolumn{7}{|c|}{ Alder Thicket } \\
\hline 1 & $\begin{array}{l}\text { Oe } \\
\text { Oa1 } \\
\text { Oa2 } \\
\text { M1 } \\
\text { M2 } \\
\text { M3 } \\
\end{array}$ & $\begin{array}{c}0--3 \\
3--9 \\
9--19 \\
19-39 \\
39--69 \\
69--109 \\
\end{array}$ & $\begin{array}{l}0.0 \\
0.0 \\
0.0 \\
0.0 \\
0.2 \\
1.0 \\
\end{array}$ & $\begin{array}{l}0.0 \\
0.1 \\
0.0 \\
0.0 \\
0.0 \\
0.0 \\
\end{array}$ & $\begin{array}{l}4.4 \\
7.1 \\
3.0 \\
4.6 \\
4.9 \\
7.4 \\
\end{array}$ & $\begin{array}{l}95.6 \\
92.8 \\
97.0 \\
95.4 \\
94.9 \\
91.5 \\
\end{array}$ \\
\hline 3 & $\begin{array}{l}\text { Oe } \\
\text { Oa } \\
\text { Oa } \\
\text { M1 } \\
\text { M2 } \\
\text { M3 }\end{array}$ & $\begin{array}{c}0--3 \\
03--25 \\
25--35 \\
35--55 \\
55-85 \\
85--125\end{array}$ & $\begin{array}{l}0.0 \\
0.0 \\
0.0 \\
0.0 \\
0.6 \\
0.9\end{array}$ & $\begin{array}{l}0.0 \\
1.0 \\
0.0 \\
0.0 \\
0.0 \\
0.0\end{array}$ & $\begin{array}{c}14.4 \\
38.1 \\
21.6 \\
3.4 \\
4.7 \\
9.4\end{array}$ & $\begin{array}{l}85.6 \\
61.0 \\
78.4 \\
96.6 \\
94.7 \\
89.7\end{array}$ \\
\hline \multicolumn{7}{|c|}{ Forested Wetland } \\
\hline 1 & $\begin{array}{l}\text { Oi } \\
\text { M1 } \\
\text { M2 } \\
\text { M3 } \\
\text { M4 } \\
\text { M5 } \\
\end{array}$ & $\begin{array}{c}0--7 \\
7--11 \\
11--21 \\
21--41 \\
41--71 \\
71--111 \\
\end{array}$ & $\begin{array}{l}0.9 \\
0.0 \\
0.0 \\
1.1 \\
1.0 \\
1.8 \\
\end{array}$ & $\begin{array}{l}0.0 \\
0.0 \\
0.0 \\
0.0 \\
0.0 \\
0.0 \\
\end{array}$ & $\begin{array}{l}1.3 \\
1.7 \\
8.9 \\
0.0 \\
0.7 \\
0.0\end{array}$ & $\begin{array}{l}97.8 \\
98.3 \\
91.1 \\
98.9 \\
98.3 \\
98.2\end{array}$ \\
\hline 2 & $\begin{array}{l}\text { Oe } \\
\text { Oa } \\
\text { M1 } \\
\text { M2 } \\
\text { M3 } \\
\text { M4 } \\
\end{array}$ & $\begin{array}{c}0--4 \\
4--14 \\
14--34 \\
34--64 \\
64--104 \\
104--150 \\
\end{array}$ & $\begin{array}{l}0.3 \\
0.1 \\
0.3 \\
2.4 \\
6.7 \\
4.3 \\
\end{array}$ & $\begin{array}{l}0.0 \\
0.0 \\
0.0 \\
0.0 \\
0.0 \\
0.0\end{array}$ & $\begin{array}{c}4.6 \\
0.9 \\
2.0 \\
14.9 \\
2.4 \\
0.0\end{array}$ & $\begin{array}{l}95.2 \\
98.9 \\
97.6 \\
82.7 \\
90.9 \\
95.7\end{array}$ \\
\hline \multicolumn{7}{|c|}{ Scrub Shrub } \\
\hline 1 & $\begin{array}{l}\text { Oa } \\
\text { M1 } \\
\text { M2 } \\
\text { M3 } \\
\text { M4 } \\
\end{array}$ & $\begin{array}{c}0--4 \\
4--14 \\
14--34 \\
34--64 \\
64--104 \\
\end{array}$ & $\begin{array}{l}0.1 \\
0.0 \\
0.0 \\
9.1 \\
5.0 \\
\end{array}$ & $\begin{array}{l}0.0 \\
0.0 \\
0.0 \\
0.0 \\
0.0 \\
\end{array}$ & $\begin{array}{l}2.5 \\
2.3 \\
1.5 \\
1.4 \\
0.9 \\
\end{array}$ & $\begin{array}{l}97.4 \\
97.7 \\
98.5 \\
89.5 \\
94.1\end{array}$ \\
\hline 2 & $\begin{array}{l}\text { Oa } \\
\text { M1 } \\
\text { M2 } \\
\text { M3 } \\
\text { M4 }\end{array}$ & $\begin{array}{c}0--9 \\
9--19 \\
19--39 \\
39--69 \\
69--109\end{array}$ & $\begin{array}{l}0.4 \\
0.0 \\
0.5 \\
3.8 \\
2.6\end{array}$ & $\begin{array}{l}0.0 \\
0.0 \\
0.0 \\
0.0 \\
0.0\end{array}$ & $\begin{array}{l}2.8 \\
9.4 \\
0.8 \\
0.0 \\
0.0\end{array}$ & $\begin{array}{l}96.9 \\
90.6 \\
98.6 \\
96.2 \\
97.4\end{array}$ \\
\hline
\end{tabular}




\begin{tabular}{|c|c|c|c|c|c|c|}
\hline \multirow[t]{2}{*}{ Transect-Stop } & \multirow[t]{2}{*}{ Soil Type } & Sample Depth & $\mathrm{SO}_{4}$ & AVS & CRS & OS \\
\hline & & $\mathrm{cm}$ & \multicolumn{4}{|c|}{$\%$ of total sulfur } \\
\hline \multicolumn{7}{|c|}{ Fen-Marsh } \\
\hline $1--2$ & $\begin{array}{l}\text { Oi } \\
\text { Oe } \\
\text { Oa } \\
\text { Oa } \\
\text { Oa } \\
\text { M1 } \\
\text { M2 } \\
\text { M3 } \\
\end{array}$ & $\begin{array}{c}0--8 \\
8--16 \\
16--41 \\
41--48 \\
48--58 \\
58--78 \\
78--108 \\
108--148 \\
\end{array}$ & $\begin{array}{l}0.0 \\
3.5 \\
0.0 \\
1.1 \\
0.0 \\
0.0 \\
0.3 \\
0.5 \\
\end{array}$ & $\begin{array}{c}0.0 \\
15.5 \\
0.1 \\
0.1 \\
0.0 \\
0.0 \\
0.0 \\
0.0 \\
\end{array}$ & $\begin{array}{c}10.6 \\
44.7 \\
20.8 \\
23.3 \\
15.8 \\
3.2 \\
4.9 \\
1.4 \\
\end{array}$ & $\begin{array}{l}89.4 \\
36.3 \\
79.1 \\
75.4 \\
84.1 \\
96.8 \\
94.8 \\
98.1\end{array}$ \\
\hline $2--1$ & $\begin{array}{l}\mathrm{Oi} \\
\mathrm{Oe} \\
\mathrm{Oa} \\
\mathrm{Oa} \\
\mathrm{Oa}\end{array}$ & $\begin{array}{c}0--4 \\
4--42 \\
42--52 \\
52--72 \\
72--102 \\
\end{array}$ & $\begin{array}{c}32.4 \\
1.8 \\
2.1 \\
0.9 \\
0.0 \\
\end{array}$ & $\begin{array}{l}0.1 \\
0.2 \\
0.1 \\
0.1 \\
0.0 \\
\end{array}$ & $\begin{array}{c}6.1 \\
21.3 \\
21.2 \\
25.3 \\
18.6 \\
\end{array}$ & $\begin{array}{l}61.5 \\
76.7 \\
76.6 \\
73.7 \\
81.4 \\
\end{array}$ \\
\hline $2--3$ & $\begin{array}{l}\mathrm{Oe} \\
\mathrm{Oa} \\
\mathrm{Oa} \\
\mathrm{Oa} \\
\mathrm{Oa} \\
\mathrm{Oa} \\
\end{array}$ & $\begin{array}{c}0--21 \\
21-31 \\
31-41 \\
41-61 \\
61-91 \\
91-120+ \\
\end{array}$ & $\begin{array}{l}0.7 \\
0.2 \\
0.3 \\
0.4 \\
0.4 \\
0.4 \\
\end{array}$ & $\begin{array}{l}0.0 \\
0.2 \\
0.0 \\
0.0 \\
0.0 \\
0.0 \\
\end{array}$ & $\begin{array}{l}3.7 \\
3.1 \\
3.6 \\
2.1 \\
1.4 \\
2.2 \\
\end{array}$ & $\begin{array}{l}95.7 \\
96.5 \\
96.1 \\
97.6 \\
98.2 \\
97.4 \\
\end{array}$ \\
\hline $2--4$ & $\begin{array}{l}\text { Oi } \\
\text { Oe } \\
\text { Oa } \\
\text { Oa } \\
\text { Oa } \\
\text { Oa } \\
\text { M1 }\end{array}$ & $\begin{array}{c}0--23 \\
23--33 \\
33--43 \\
43--53 \\
53--73 \\
73--103 \\
103--143\end{array}$ & $\begin{array}{c}0.8 \\
0.9 \\
0.3 \\
0.5 \\
0.3 \\
0.4 \\
12.1\end{array}$ & $\begin{array}{l}0.0 \\
0.0 \\
0.0 \\
0.0 \\
0.0 \\
0.0 \\
0.0\end{array}$ & $\begin{array}{l}1.4 \\
2.6 \\
4.9 \\
0.6 \\
0.4 \\
0.8 \\
7.2\end{array}$ & $\begin{array}{l}97.8 \\
96.5 \\
94.8 \\
98.9 \\
99.3 \\
98.8 \\
80.7\end{array}$ \\
\hline
\end{tabular}




\section{Vita}

The author was born in Reading, Pennsylvania in 1976. He completed his B.S. degrees Agriculture with majors in Agronomy an Environmental Protection at West Virginia University in 1999. He then attended graduate school at West Virginia University and obtained a Masters of Science Degree in Plant and Soil Sciences. 